\title{
UMA FRESTA NA NEBLI NA estudo da possibilidade de Restauro Urbano do Serro
}

Ana Aparecida Barbosa EESC - USP 


\section{A n a A p a r e c i d a B a r b o s a}

\section{U M A F E S T A N A N B L I N A Estudo da Possibilidade de Restauro Urbano do Serro}

Dissertação apresentada ao Departamento de Arquitetura e Urbanismo da Escola de Engenharia de São Carlos da Universidade de São Paulo, para a obtenção do título de mestre em Arquitetura e Urbanismo.

Área de concentração: Teoria e História da Arquitetura e do Urbanismo Orientadora: Prof. a Dr.a Maria Ângela P.C.S. Bortolucci 
AUTORIZO A REPRODUÇÃO E DIVULGAÇÃO TOTAL OU PARCIAL DESTE TRABALHO, POR QUALQUER MEIO CONVENCIONAL OU ELETRÔNICO, PARA FINS DE ESTUDO E PESQUISA, DESDE QUE CITADA A FONTE.

Ficha catalográfica preparada pela Seção de Tratamento da Informação do Serviço de Biblioteca - EESC/USP

B238f

Barbosa, Ana Aparecida

Uma fresta na neblina : estudo da possibilidade de restauro urbano do Serro / Ana Aparecida Barbosa; orientadora Maria Ângela P.C.S. Bortolucci. -- São Carlos, 2007.

Dissertação (Mestrado-Programa de Pós-Graduação em Arquitetura e Urbanismo. Área de Concentração: Teoria e História da Arquitetura e Urbanismo) -- Escola de Engenharia de São Carlos da Universidade de São Paulo, 2007.

1. Serro (MG). 2. Restauro Urbano. 3. Patrimônio cultural. 4. Cidade. 5. Preservação. 6. Restauração. 7. Cesare Brandi. I. Título. 


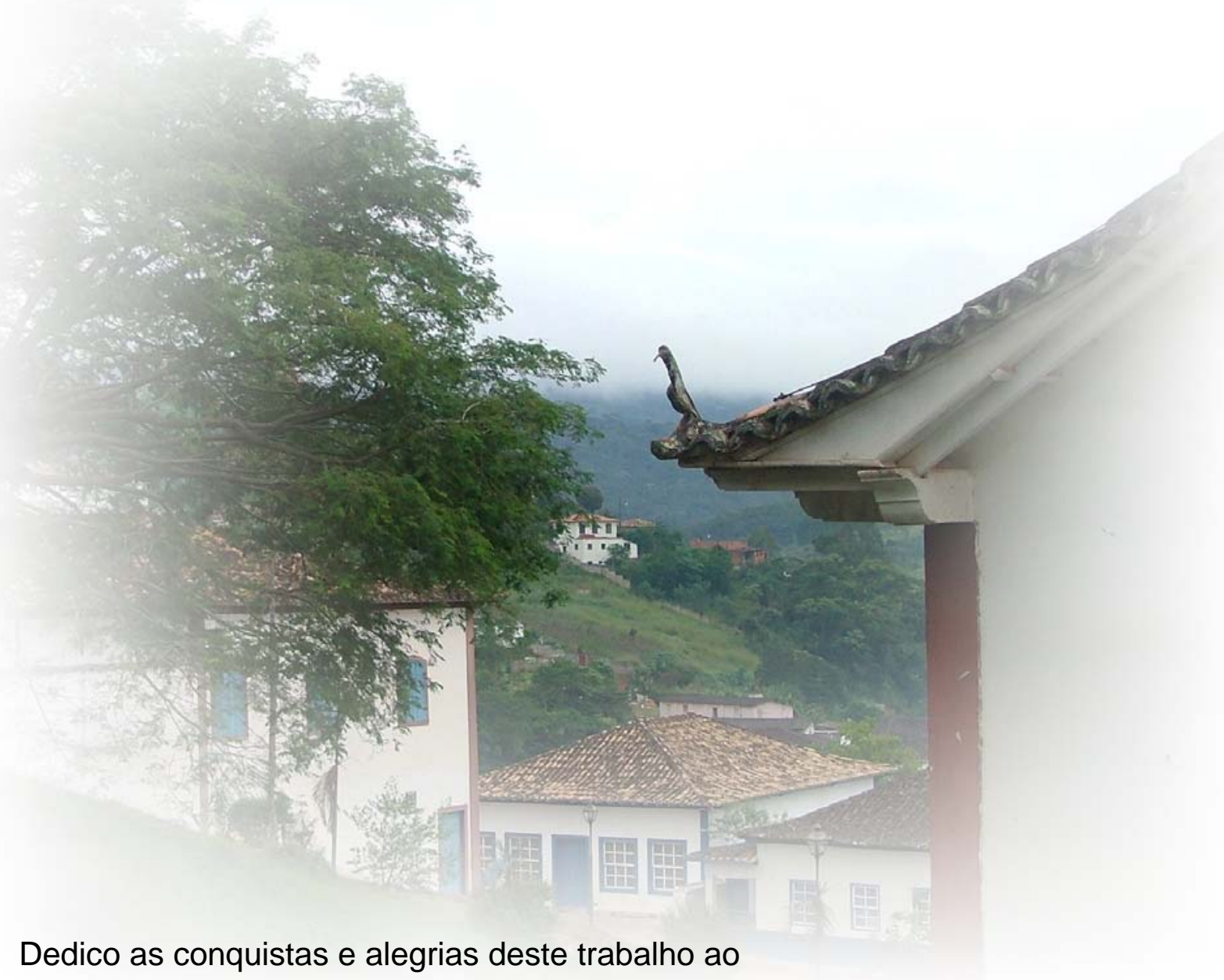

Dedico as conquistas e alegrias deste trabalho ao

Olavo dos Santos Pereira Junior, companheiro de todos os momentos, amor querido, benção em minha vida. 


\section{A DEUS}

Aos meus amados pais Wenceslau e Olandina, pelo exemplo de vida, e pela certeza de que o conhecimento se faz a partir da cultura e da determinação;

por me possibilitarem tudo aquilo cuja oportunidade não tiveram.

Aos meus irmãos queridos, Marlene, Wanderlei, Wilma, Maria do Carmo, Hilza, Walace e Mirandinha por todo apoio e contribuição no caminhar diário da vida, sempre objetivando um sucesso mútuo e compartilhado;

e, neste trabalho, em especial à Mariza, Ana, Rubinho e Helena. 
Aos mestres,

Maria Ângela Bortolucci

e

Leonardo Barci Castriota 
Agradeço à querida professora, mestra Maria Ângela Bortolucci por generosamente me aceitar como orientanda, conduzindo este trabalho com equilíbrio, sensibilidade e muita competência, assim como ao professor Leonardo Barci Castriota pelas orientações complementares certeiras na direção de um adequado recorte do objeto; à professora Beatriz Mugayar Kühl, que prestou importantes orientações para uma pertinente atualização bibliográfica do tema da restauração; ao professor Carlos Roberto Monteiro de Andrade contribuindo com, carinho e profissionalismo, preciosas incursões no que se refere a Camillo Sitte; ao professor Silloto, pela gentileza e contribuição; a amiga Til Costa Pestana que compartilhou conhecimentos sobre patrimônio cultural numa conduta constante ao debate científico sobre a preservação da cidade; ao IPHAN, Lia Motta, Claúdia Lage e Sérgio Abrahão, por terem me apresentado a cidade como patrimônio cultural; aos funcionários do IPHAN de Diamantina, Tiradentes, Sabará, Serro e Belo Horizonte; aos colegas do Laboratório de Fotodocumentação Sylvio de Vasconcellos da EA UFMG, especialmente ao Archimedes e à Carla; aos funcionários, da Biblioteca da EA UFMG e da EESC USP; ao ensino público brasileiro e órgãos de fomento, CAPES pelo apoio nesta pesquisa, e pela capacidade de estimular a expansão do conhecimento democrático; aos colegas Vladimir Benincasa, Luciana Mascaro e Michele sempre companheiros, e todos os demais colegas do nosso Grupo de Pesquisa, Preta, Camila Corsi, Marcus, Valéria, Paola, Mateus...; ao Programa de Pós Graduação em Arquitetura e Urbanismo da EESC, da Universidade de São Paulo, especialmente ao Marcelinho e ao Geraldo; aos anjos da guarda Maria Vilma da EA UFMG e João Ângelo Chiari 
Amar o perdido deixa confundido este coração.

Nada pode o olvido contra o sem sentido apelo do Não.

As coisas tangíveis tornam-se insensíveis

à palma da mão.

Mas as coisas findas, muito mais que lindas, essas ficarão.

Memória, Carlos Drummond de Andrade 


\section{Resumo}

BARBOSA, A.A. (2007). Uma fresta na neblina: estudo da possibilidade de restauro urbano do Serro. 288p. Dissertação (Mestrado) - Escola de Engenharia de São Carlos, Universidade de São Paulo, São Carlos, 2007.

Estudo da possibilidade de restauro urbano da cidade patrimônio cultural. Reforça o caráter artístico da cidade, reconhece a sua materialidade através da percepção espacial, e identifica condições físicas de espaços urbanos. Discute suas transformações para a preservação. Adota, como estudo de caso, Serro (MG) reconhecendo sua natureza artística. Interpreta a Teoria do Restauro de Cesare Brandi focando o espaço urbano percebido, a partir da leitura da cidade antiga brasileira, através dos princípios artísticos de Camillo Sitte. Conclui que a cidade passa por transformações que podem comprometer sua condição artística, necessitando, desta forma, de ações de preservação apropriadas.

Palavras-chave: Restauro urbano. Serro (MG). Patrimônio cultural. Cidade. Preservação. Restauração. Cesare Brandi. 


\section{Abstract}

BARBOSA, A.A. (2007). An opening in the fog: Study of possibility of the restore urban of the Serro. 288p. M.Sc. (Dissertation) - Escola de Engenharia de São Carlos, Universidade de São Paulo, São Carlos, 2007.

Study of possibility of the restore urban of the patrimony city. It reinforces the artistic character of the city, it recognizes your materiality through the space perception and it identifies physical conditions of urban spaces. It discusses your transformations for the preservation. The city of Serro (MG) was used as case study due its artistic nature. This study interprets the Cesare Brandi's Theory of Restoration applied the urban space, and this urban space is interpreted through analysis of the brasilian old city (colonial city), according to artistic principles of Camillo Sitte. Like this we ended that the city changes and this change can to alter its artistic nature, imposing apropriate preservation action.

Keywords: Restore urban. Serro (MG). Work of art. Cultural patrimony. City. Preservation. Restoration. Cesare Brandi. 


\section{Sumário}

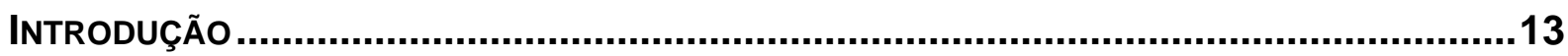

1. CAPÍtUlo 1 - PRINCíPIOS PARA UM RESTAURo URBANo .............................................23

1.1. "Teoria do Restauro" de Cesare Brandi .........................................30

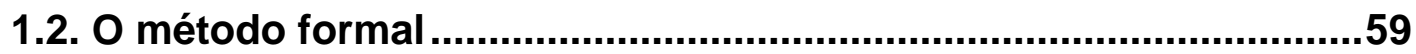

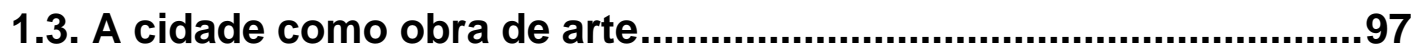

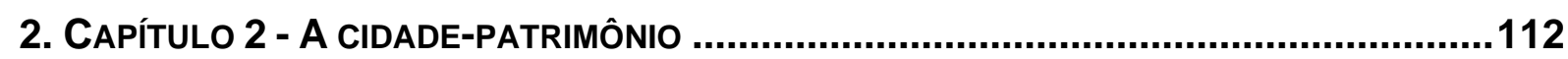

2.1. Atribuição do valor estético ........................................................112

2.2. Formação e transformação da cidade ...........................................122

2.3. A preservação e a não preservação..............................................142

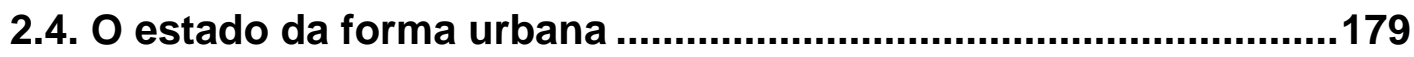

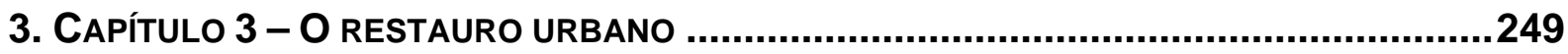

3.1. A restauração da cidade e a Teoria brandiana ............................250

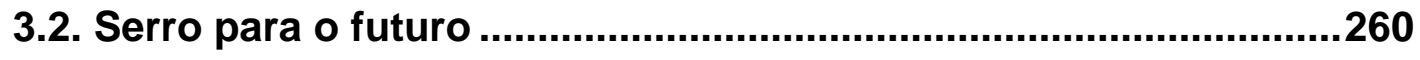

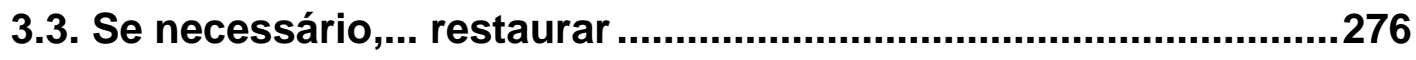

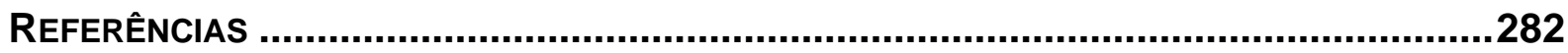





\section{Introdução}

Esta pesquisa tem sua origem a partir da observação direta da condição atual de preservação das cidades setecentistas mineiras, da realidade de entendimento predominante sobre espaço urbano por agentes, que possuem grande responsabilidade por importantes transformações pelas quais a cidade passa. Percebemos graves deficiências quanto ao entendimento do significado dessas cidades e o quanto é importante a forma de tratar a preservação. Esta nossa inquietação estava sempre presente durante o desenvolvimento de trabalhos pelo Instituto do Patrimônio Histórico e Artístico Nacional (IPHAN) em cidades como Diamantina, Tiradentes, Sabará, e Serro.

Desta oportunidade de conhecermos diferentes cidades mineiras, em diferentes condições econômicas e sociais, com origem e formação distintas, apesar de ter em comum a mineração, foi possível percebermos o que realmente favorece a salvaguarda de um acervo urbano: é o seu reconhecimento como tal, principalmente por sua população local. E, ligado a isso, o reconhecimento das especificidades do acervo por agentes como arquitetos e engenheiros, que transformam estas cidades.

Neste universo, podemos entender Serro (MG) de maneira diversa das demais, pois o turismo ainda não faz parte da base de sua economia, e a área mais antiga é habitada predominantemente pela população própria do lugar. Além disso, tem em sua origem econômica, tradicional e histórica, a mineração a agropecuária. 
Entendemos que disso resulta um povo que se relaciona com seu habitat com mais intimidade, uma vez que na agricultura, para se colher, é preciso cuidar da terra; e na mineração, basicamente, explorar o existente. Serro é diferente de Tiradentes ou Ouro Preto com relação a esta raiz exploratória a qual o turismo, se vincula, podendo resultar em uma comunidade despreocupada com os motivos da preservação e mais vinculada a resultados imediatistas. Diamantina, a partir de 1999, após a obtenção do título de patrimônio da humanidade, se voltou para o caminho do turismo e vivencia fortes transformações, refletindo na população local dúvidas quanto aos motivos da preservação de sua cidade. Sabará possui uma população de certa forma "desterritorializada", devido a sua condição de região metropolitana de Belo Horizonte, referenciada por muitos como "cidade dormitório".

Cada cidade tem sua especificidade, e neste universo entendemos que Serro (MG) representa o conjunto urbano setecentista mineiro, tombado pelo IPHAN mais íntegro, no sentido de uma maior aproximação com suas origens, se apresentando como objeto de estudo ideal para a verificação de um possível restauro urbano. Este quadro é reforçado por sua escala urbana, com maiores possibilidades de domínio de "um inteiro" que favorece nossas discussões urbanísticas de preservação.

O desenvolvimento deste trabalho nos cria a expectativa de somar maiores contribuições. Com o conhecimento dessas cidades, acrescido da aproximação com os demais conjuntos urbanos tombados pelo IPHAN, devido à sua natureza nacional, tivemos a oportunidade de amplo aprendizado por meio de colaborações em trabalhos em São João Del Rei (MG), Mariana (MG), Ouro Preto (MG), e cidades como Prados (MG), onde participamos, em 2002, da elaboração de um plano de preservação para o entorno da igreja tombada de Nossa Senhora da Conceição. 
Esta realidade tem colaborado, de maneira positiva, nos debates que esta pesquisa exige.

Quando trabalhamos no Serro pelo IPHAN, mapeamos lacunas relacionadas à ausência de edificações antigas e verificamos a existência de danos na cidade tombada. Então nos perguntávamos se seria possível um restauro urbano. Como tratarmos um objeto em especial condição de reconhecimento de valor artístico? E quais os mecanismos para viabilizarmos este processo?

A partir de então, verificamos a necessidade de ampliação do conhecimento para lidar com tais questões e ingressamos no Programa de Pós-Graduação em Arquitetura e Urbanismo da EESC/USP. Durante o desenvolvimento da pósgraduação, realizamos ampla pesquisa bibliográfica e levantamento de dados sobre o tema restauração. Consultamos bibliotecas, arquivos e sites sobre a história do restauro e seus principais teóricos. Já no início do processo, identificamos o período histórico em que o espaço urbano, uma cidade inteira passaram a ser reconhecida como bem patrimonial, sendo Choay (2001) fundamental neste momento.

Como nosso propósito foca a questão urbana pensando em seu restauro, avançamos a pesquisa bibliográfica rumo à aproximação entre a cidade e sua preservação, conservação e restauração. Contamos nesta fase, dentre vários autores, com a colaboração de Dourado (2003), que nos apontou vários caminhos. Dentre os estudiosos da cidade e de sua preservação, aquele que mais se aproximou do tema restauração urbana foi o italiano Gustavo Giovannoni. Jokilehto (1986) lembra que Giovannoni desenvolveu a Teoria de 'Diradamento', onde ele destaca a importância para a cidade, da arquitetura de pequenas edificações, aquela 
não monumental. Giovannoni "estava consciente de que a cidade desenvolveu-se ao longo dos anos, e nela foram introduzidos estilos diferentes em períodos diferentes" (JOKILEHTO, 1986, p.196, tradução da autora).

Mas, nos voltamos aos teóricos clássicos do restauro, como Viollet-le-Duc, John Ruskin, Camilo Boito, Alois Riegl, em que percebemos uma abordagem da questão do restauro a partir das inquietações de cada época, gerando importante legado, um após o outro, num desenvolvimento constante de amplos avanços do tema enquanto disciplina autônoma. Temos ciência de que todos oferecem destacada contribuição, mas para uma abordagem mais direta, voltada para o restauro da cidade, acreditamos que encontraríamos em Giovannoni a maior contribuição para o debate que buscamos. Mesmo tendo o discernimento de conceitos ainda atuais desses teóricos clássicos da restauração, víamos, à exceção de Giovannoni, que eles não apresentavam em suas pesquisas a visão mais contemporânea sobre o tema do restauro para uma demanda urbana.

Pensamos, então, ser o restauro científico de Gustavo Giovannoni o mais adequado recurso da linguagem da preservação para a avaliação de um possível restauro urbano. Entretanto, a partir do momento que nossas leituras e pesquisas avançavam e descobríamos novas abordagens, ficávamos mais distantes de Giovannoni que, apesar de ter sido inovador principalmente quanto à questão urbana, sofreu importantes influências de Camillo Sitte, quanto à forma de percepção dos valores visuais e pinturescos da cidade (JOKILEHTO, 1986). A partir da segunda guerra mundial Giovannoni viu seus princípios de restauro entendidos como insuficientes, uma vez que os amplos danos que surgiram apresentavam demandas de análises e soluções não contempladas pelo seu método do restauro 
científico. O ponto mais determinante neste sentido trata da ausência, em seus estudos, da dimensão figurativa da imagem, onde "neutros" não funcionavam na recomposição de obras severamente danificadas ou destruídas. A partir dessas constatações decorrentes dos graves prejuízos causados pela guerra no patrimônio europeu, ocorreram novas reflexões e pesquisas que culminaram no surgimento do restauro crítico, quando novos pesquisadores perceberam que cada caso é um caso diferente. E, conseqüentemente a reflexão de que a obra danificada deva ser tratada como única, vinculada ao conhecimento de história da arte do restaurador, de sua sensibilidade, experiência, dentre outros condicionantes.

A partir do final da década de 1940, aconteceu uma revolução no entendimento de restauro, que historicamente foi conflituoso e passível de leituras diversas. Da vivência desse período histórico, na década de 1960, Cesare Brandi publicou um compilado de seus textos e produção sobre o tema, com o título de "Teoria del Restauro", e a partir de uma filosofia como a kantiana criou sua própria teoria do restauro, sem referenciar seus antecessores (CARBONARA, 2003).

Brandi (2005) busca definir caminhos para um entendimento do objeto a que se pretende restaurar para então pensar na realização. Para ele, a "restauração constitui o momento metodológico do reconhecimento da obra de arte, na sua consciência física e na dúplice polaridade estética e histórica, com vistas à sua transmissão para o futuro" (BRANDI, 2005, p.30). Ou seja, a ação de restaurar está vinculada ao reconhecimento da obra de arte como tal, e é o objeto que a determina.

Para Azevedo (2003), desde o trabalho de Brandi, a produção sobre o tema do restauro não teve colaboração neste teor e nesta ordem de grandeza. Existem 
posturas diferentes da sua, como o atual "conservadorismo puro" que busca desmontar a Teoria brandiana em sua base, fundamentada no reconhecimento do objeto a ser restaurado como sendo obra-de-arte. Para estudiosos do restauro como Carbonara (2006), Brandi ainda não foi superado, mostrando-se absolutamente atual.

Acreditamos, portanto, que Cesare Brandi, por meio de sua Teoria do Restauro, represente o caminho mais adequado e atual para se avaliar a possibilidade de um restauro urbano, pois seu pressuposto é que se trate de uma obra-de-arte, exigindo uma análise de natureza formal e estética, como a apreensão do espaço visual da cidade (ARGAN, 1998). Então, neste sentido, retomamos nossas pesquisas quanto ao reconhecimento da cidade como bem patrimonial.

a noção de patrimônio urbano histórico constituiu-se na contramão do
processo de urbanização dominante. Ela é o resultado de uma dialética da
história e da historicidade que se processa entre três abordagens [memorial,
histórica e historial] (CHOAY, 2001 p.180).

Percebemos que a abordagem histórica discutida por Choay (2001) encontrase presente, de maneira expressiva, na obra de Camillo Sitte, que apresenta um teor técnico quanto à abordagem estética do espaço urbano antigo e do importante caráter humano em sua manutenção. Para Sitte (1992), a percepção visual do espaço urbano deve trazer ao observador a sensação do belo, do agradável.

Camillo Sitte é considerado por Choay (2001) como o pai da morfologia urbana, e tem sido objeto de constantes estudos retomados com maior vigor a partir da década de 60, mostrando-se contemporâneo. Seu trabalho sobre os princípios artísticos da construção dos espaços públicos se aproxima de maneira técnica da 
leitura do espaço urbano como obra de arte. E esta leitura ocorre a partir da forma, dos dados espaciais, da materialidade urbana.

Cesare Brandi (2005) acredita que se restaura apenas a matéria da obra de arte. Para verificarmos a possibilidade de um restauro urbano, entendemos como sendo adequado partir de uma leitura pioneira e contemporânea. Elegemos Camillo Sitte em "A construção das cidades segundo seus princípios artísticos", como o instrumento que possui o máximo de qualidades necessárias para satisfazer os critérios de apreciação apontados por Brandi (2005), para atingirmos nosso objetivo de verificar a possibilidade de um restauro urbano da cidade patrimônio cultural, reforçarmos o caráter artístico da cidade, reconhecermos a sua materialidade por meio da percepção espacial, identificarmos condições físicas de espaços urbanos, discutirmos suas transformações para a preservação.

Contudo, percebemos a necessidade de complementarmos os estudos para o entendimento da cidade como obra de arte. Em entrevistas com arquitetos e engenheiros que atuam em cidades reconhecidas como obra de arte, constatamos a deficiência quanto ao reconhecimento desta natureza artística (BARBOSA, 2005). A partir de nossas análises e pesquisa bibliográfica, percebemos em Argan (1998) uma leitura do historiador da arte com amplitude do objeto de maneira global, que transporta o conceito de cidade para um universo mais amplo do que aquele entendido convencionalmente, e que traz à tona as relações internas de uma edificação, a maneira de se vestir e o espaço tido como rural. Entendemos que esta visão é das mais atuais quando aplicada ao universo patrimonial contemporâneo. 
Além das pesquisas bibliográficas, realizamos levantamentos de campo para o conhecimento pleno do objeto de estudo. Após a decisão de trabalhar Serro (MG), ampliamos nossas investigações bibliográficas a respeito dessa cidade, assim como análises e levantamentos de dados no próprio local objeto do trabalho. Fotografamos percursos, praças, monumentos; registramos vistas panorâmicas e parciais da cidade, elaboramos mapas temáticos, assim como complementamos o material de pesquisa com acervo fotográfico e documental levantado por outros pesquisadores que estão trabalhando com a cidade, vinculados a instituições como: a Universidade Federal de Minas Gerais, com o Plano Diretor; o Ministério da Cultura, com o Programa Monumenta; o Instituto do Patrimônio Histórico e Artístico Estadual e a Prefeitura Municipal de Serro que, além de participarem do Programa Monumenta, participam da Lei Estadual de Incentivo à Cultura de Minas Gerais, que dispõe sobre a concessão de incentivos fiscais com o objetivo de estimular a realização de projetos culturais no Estado. Salientamos, ainda, a valiosa colaboração do IPHAN com seu vasto arquivo sobre a cidade desde seu tombamento, dentre outras contribuições.

Após inúmeras reflexões, estruturamos a dissertação em três capítulos: o primeiro, de caráter teórico-conceitual, para a discussão e apresentação dos princípios da teoria do restauro de Cesare Brandi, de como se pode realizar uma análise formal da cidade, e de que maneira ela pode ser percebida como obra de arte, com destaque para as contribuições de Cesare Brandi, Camillo Sitte e Giulio Carlo Argan.

O segundo capítulo consta da história e transformação urbana do objeto cidade setecentista de Serro -, da trajetória de preservação da cidade, da sua 
apresentação a partir do estudo de seu valor estético, lido a partir dos conceitos apontados principalmente por Argan, Sitte e aqueles reconhecidos pelo IPHAN em seu tombamento; das análises do estado atual de sua forma urbana, utilizando os princípios artísticos da construção do espaço urbano por Camillo Sitte.

O terceiro, consta de preciosa discussão que aborda a relação dos critérios da Teoria brandiana que são passíveis de aplicação ao universo urbano. Esta aplicabilidade é avaliada a partir da condição da forma urbana atual demonstrada no capítulo anterior. Em caráter ilustrativo, desenvolvemos a verificação da possibilidade de um restauro urbano em ambientes da cidade de Serro - praça Getúlio Vargas; praça Dom Epaminondas; praça João Pinheiro - , mas sempre entendendo que esses locais pertencem a um inteiro que é a cidade, garantindo a unidade de sua espacialidade conforme entendimento de Camillo Sitte. Tais recortes se destacam pela relevância de suas características morfológicas e estéticas, e pela sua trajetória histórica, que possibilitou a ligação entre eles por caminhos seculares. Nestes espaços foi aplicada a Teoria do Restauro de Cesare e Brandi a partir da condição do estado em que se encontra a forma urbana percebida por princípios de Camilo Sitte.

Consideramos estas discussões fundamentais para o universo brasileiro, uma vez que ações de preservação urbana ainda são precárias, e muitas vezes confusas. Ocorrem a vulgarização e o uso de termos específicos da área de restauro, reabilitação, revitalização, recuperação, conservação, dentre outras, evidenciando falta de clareza dos seus significados. Disso resulta que, em situações de catástrofes e perdas graves do patrimônio cultural, valores emocionais se sobressaem e os critérios de reconstrução "em estilo" predominam (sobrado 
incendiado em Ouro Preto). Atrelado a isso, Baptista (2002) aponta a gravidade da deterioração da reflexão crítica que vivemos, atualmente, decorrente do expressivo desenvolvimento tecnológico, apesar da criação de melhores condições de trabalho da técnica de restauro.

A confirmação de um restauro urbano trata de um grande desafio, pois, conforme dissemos anteriormente, são muitos os profissionais e estudiosos que não vêem a cidade como obra de arte, mesmo considerando o alargamento do conceito de bem cultural, ou que não acreditam ser aplicável a Teoria brandiana no espaço urbano por sua múltipla constituição, além de sua materialidade. 


\section{Capítulo 1 - Princípios para um restauro urbano}

Neste capítulo desenvolvemos o embasamento teórico conceitual que se exige às análises e reflexões para o alcance de nosso objetivo principal quanto à verificação da possibilidade de um restauro urbano. Descortina-se a faculdade intelectual voltada para a organização e unificação das sensações múltiplas em conceitos e juízos adequados ao conhecimento do mundo sensível da restauração a partir de Cesare Brandi. Surge, então, a percepção da espacialidade urbana, em sua materialidade reconhecida na experiência vivida da consciência, em uma exploração do espaço visual da cidade por Camillo Sitte. Desvendamos o entendimento desta artisticidade com colaboração de Brandi, Sitte, Argan e Benedetto Croce por possuir importante contribuição às bases do restauro crítico.

\section{Restauração}

O tema da restauração se apresenta sempre em debate; entretanto, já é compreendido como uma disciplina desde a década de vinte do século XIX (CHOAY, 2001). O modo contemporâneo de vermos os bens culturais, a salvaguarda, não se limita exclusivamente às "obras de arte" de especial interesse, porém contempla os bens considerados mais simples, de "baixa colocação", mas que carregam 
destacada significação cultural. Aquilo que no passado era entendido como "Monumento Histórico" - referindo-se a obras espetaculares -; atualmente é utilizado a partir de uma leitura mais próxima da origem do termo Monumento, conforme entendimentos de Alois Riegl, mostrando-se como dispositivo da memória coletiva e de bens históricos.

Para melhor compreensão de nossas opções quanto à questão da restauração urbana, indicamos, de maneira geral, apontamentos sobre a trajetória de modificações sobre noções de restauro para compreendermos que a preservação de bens culturais, tal como entendida hoje, tem raízes remotas.

\begin{abstract}
É possível detectá-las no século $\mathrm{XV}$, quando, de forma paulatina, as intervenções em obras de épocas passadas deixam de ter como moventes questões de ordem essencialmente prática e utilitária e começam a ter motivação cultural. A partir de finais do século XVIII a preservação vai se sistematizar, assumindo, de forma gradativa, uma maior autonomia e consolida-se como campo disciplinar autônomo principalmente a partir do século XX (KÜHL, 2006, p.3).
\end{abstract}

Percebemos que as produções vinculadas ao tema da preservação, como princípios e preceitos, estão fundamentadas em pelo menos 200 (duzentos) anos de sólidas e respeitadas experimentações. Mas devemos ter atenção, pois divergências são constantes, apesar de não impedir preciosas discussões e contribuições criteriosas para a área, proporcionando ao tema da preservação importantes instrumentos de reflexão.

No que se refere à arquitetura, Feilden (1982) afirma que o trabalho de preservação requer tratamento de materiais em um ambiente aberto e virtualmente incontrolável, onde devem ser permitidos os efeitos do tempo. Entretanto, historicamente, as intervenções feitas em edifícios já existentes foram, ao longo do 
tempo, voltadas, em geral, para sua adaptação às necessidades da época e ditadas por exigências práticas e de uso.

\begin{abstract}
noções que floresceram, isolada e esporadicamente, a partir do Renascimento e amadureceram entre os séculos $X V$ e $X V I I I$, foram posteriormente conjugadas na formação das vertentes teóricas da restauração: o respeito pela matéria original; a idéia de reversibilidade e distinguibilidade da intervenção; a importância da documentação e de uma metodologia científica; o uso como um meio de preservar os edifícios e não como a finalidade da intervenção; o interesse por aspectos conservativos e de mínima intervenção; a noção de ruptura entre passado e presente (KÜHL, 2006, p.3).
\end{abstract}

Ainda podemos destacar a importância dos debates decorrentes das transformações e demandas criadas pela Revolução Industrial e principalmente pela Revolução Francesa, quanto aos valores de patrimônio. A preservação de monumentos históricos se transforma em uma conotação fundamentalmente cultural, vinculada aos valores formais, históricos, simbólicos e memoriais, em contraposição às ações de cunho prático (CHOAY, 2001).

Todo esse processo de reflexões teóricas esteve atrelado a experiências práticas, que a partir do século XIX obtiveram repercussão mais ampla, inclusive legislativa, em vários países europeus. Ocorreram vertentes distintas, das quais podemos destacar a busca de um estado completo para a obra, que pode não ter existido, um completamento do que não foi construído originalmente, que possui como importante representante Eugene E. Viollet-le-Duc. Outra importante vertente foi liderada por John Ruskin e William Morris, que acreditavam no respeito absoluto pela matéria original do bem, indicando sempre a manutenção periódica para prolongar o mais possível a vida do edifício, mas admitindo a possibilidade de uma possível perda. 
Kühl (2006) afirma que as experiências díspares e, mesmo, antagônicas praticadas até então foram reformuladas por Camillo Boito no final do século XIX. Ele consolidou uma via que se contrapôs à prática difusa de tentativas de voltar a um suposto estado original, unidade de estilo, ou estado anterior qualquer. O trabalho de Boito preconizava

o respeito pela matéria original, pelas marcas da passagem do tempo e pelas várias fases da obra, além de recomendar a mínima intervenção e, no caso de acréscimos, a distinguibilidade da ação contemporânea, para que esta última não fosse confundida com aquilo que subsistia da obra, o que poderia levar o observador ao engano de considerá-la como antiga (KÜHL, 2006, p.4).

No que se refere à abordagem da preservação urbana, em especial à questão do restauro, de acordo com Jokilehto (1986), Gustavo Giovannoni marcou a história da arquitetura, na conservação e restauração de edifícios históricos e cidades, destacando sua forte fundamentação em Camilo Boito, a partir do respeito às expressões de vários períodos sobrepostos no monumento.

Boito trouxe questões como a distinguibilidade, a ênfase ao valor documental dos monumentos, e Alois Riegl, no final século XIX início do século $X X$, trouxe novidades tanto para a teoria quanto para a prática da preservação e restauração dos bens culturais, contemplando aspectos normativos na Áustria, além de análises profundas sobre o papel dos Monumentos Históricos e suas formas de apreensão por uma dada sociedade.

Riegl deu passos fundamentais para consolidar a preservação de bens culturais como um campo disciplinar autônomo, que deixou de ser apenas um "auxiliar" da história da arte (assim como também contribuiu para a consolidação da própria história da arte como um campo autônomo em relação à "história geral"), passando a assumir características próprias, podendo, por sua vez, oferecer contribuições para a própria historiografia e para a criação artística contemporânea. Elaborou proposições prospectivas, que permanecem válidas ainda hoje, contendo elementos que podem ser continuamente explorados (KÜHL, 2006, p.5). 
Cláudia Reis (2006) chama a atenção para o interesse das colocações de Riegl em sua obra O Culto Moderno dos Monumentos, de 1903. Esse trabalho de Riegl se direciona a uma estruturação legislativa para a conservação na Áustria, sendo composto de três partes: a primeira, O Culto, é uma discussão teórica que fundamenta a proposta de lei; a segunda é o projeto de lei para a tutela dos monumentos; a parte final contempla as disposições para a aplicação da lei (REIS, 2006).

Riegl propunha debates sobre Monumentos Históricos distantes daqueles tradicionalmente baseados nas abordagens histórico-artísticas, como prevalecera até então. Foi inovador em considerar as formas de recepção, de percepção e de fruição dos monumentos, através dos "valores" por ele explicitados no Culto.

para Riegl, monumentos históricos eram não apenas as "obras de arte", mas qualquer obra humana com certa antigüidade (para ele, qualquer obra com mais de sessenta anos), contrapondo-se assim às políticas de preservação que se voltavam apenas aos objetos de excepcional relevância histórica e artística (KÜHL, 2006, p.5).

O "valor de antigüidade" - fundamenta as propostas de Riegl para a nova legislação, que buscava uma tutela difusa afim de assegurar a preservação de ampla gama de testemunhos relevantes de épocas passadas. Riegl considerava que os outros "valores" deviam ser aplicados, de modo alternado ou indistinto, dependendo da situação.

Cabe destacar ainda que Riegl foi um dos primeiros a evidenciar que as atuações voltadas à preservação dos Monumentos Históricos não podiam ser entendidas em sentido absoluto; para ele não existe uma única solução universalmente válida, mas comporta várias soluções, de pertinência relativa. Mas isso não significa que a ação seja arbitrária, pelo contrário (KÜHL, 2006). 
Em meados do século $X X$, foram feitas novas proposições no campo da restauração, que surgiram também em conseqüência das destruições da Segunda Guerra Mundial, evidenciando os reduzidos instrumentos teóricos até então empregados para se entender a realidade figurativa dos monumentos. As contribuições da estética não haviam sido levadas suficientemente em conta, não sendo empregados os meios conceituais disponíveis para abordar obras e extensas áreas devastadas, tornando-se evidente a inadequação de se trabalhar com "neutros" no completamento de edifícios, ou no tratamento de conjuntos urbanos, como se fizera e se propusera naquela primeira metade do século, principalmente com o restauro científico de Gustavo Giovannoni.

Foram de relevância (e permanecem atuais) textos escritos desde os anos 1940, a exemplo dos de Cesare Brandi, Roberto Pane, Renato Bonelli e Paul Philippot, atingindo-se certa posição de consenso internacional na Carta de Veneza, de 1964 (KÜHL, 2006, p.7).

Houve buscas paralelas que convergiram em alguns temas, oferecendo meios para a crítica e aprofundamento recíprocos. Autores filiados ao chamado "restauro crítico", tais como Bonelli e Pane, alicerçam suas posições nas análises das transformações históricas por que passaram as teorias de restauração, reformulando-as e articulando-as a outras enunciações da época, tais como as de Brandi, que, por sua vez, fundamenta suas proposições essencialmente através da estética e da história. E, conta com o importante vínculo às atividades práticas do Instituto Central de Restauro (ICR).

Por se fundamentar na relação dialética entre as "instâncias" estéticas e históricas da obra (ou conjunto de obras), suas proposições exigem esforço interpretativo caso a caso, e a intervenção não pode ser enquadrada, a priori, em uma determinada categoria fixa como acontecera anteriormente, em especial com as formulações de Gustavo Giovannoni (KÜHL, 2006, p.10). 
Mas o fato de cada restauração constituir um caso a ser analisado em razão das características particulares de sua especificidade no transcorrer na história não faz com que a intervenção seja arbitrária. Essa objetividade só pode ser alcançada pela reflexão teórica e crítica. Por isso, a restauração deve seguir princípios gerais através de procedimentos e conceitos consistentes, sustentados na história e na filosofia, "em uma formulação de restauro como hipótese crítica não expressa verbalmente, mas concretizada em ato" (CARBONARA, 2000, tradução da autora). A "ancoragem" nesses campos disciplinares é essencial para aqueles que atuam na preservação de bens culturais, pois possibilita que se superem atitudes ditadas unicamente por predileções individuais. Acreditamos que a restauração deve, ainda, estar vinculada a valores de hipóteses e não "di scientifica o dogmatica certezza rende subito più chiaro il senso dei criteri-guida vigenti in materia, come la distinguibilità, la reversibilità, il minimo intervento, il rispetto dell'autenticità" (CARBONARA, 2000).

Dentre as tendências atuais que procuram seguir os objetivos da preservação, podemos destacar o "restauro tipológico", que responde a princípios de imitação; a "pura conservação" com uma postura de máxima cautela, que privilegia a instância histórica, amenizando as ações do tempo na obra, assemelhando-se neste ponto ao "restauro tipológico"; a tendência "crítico-conservativa" alicerçada na teoria brandiana e na releitura de aspectos do chamado restauro crítico. De acordo com Carbonara (2006), conservativa porque parte do pressuposto de que o monumento deve ser perpetuado para o futuro, e por atuar na consciência histórica impõe a conservação de um número maior de "coisas" do passado; e crítica pela explícita atração com a formulação teórica que impulsiona o convencimento que cada 
intervenção constitui um episódio por si, não enquadrado em categorias, não respondendo a regras preestabelecidas, mas objetivando estudar a fundo cada momento, sem assumir posição dogmática ou preestabelecida.

Si dovrà quindi interrogare con viva coscienza storica l'opera, nella sua natura figurativa e materiale, nei problemi di degrado e conservazione che manifesta, perché essa stessa risponda suggerendo la strada da seguire nella specifica contingenza. Il tutto senza mai dimenticarsi di fornire una soluzione estetica al problema conservativo e di considerare anche i valori figurativi indotti, sulle antiche superfici, dall'invecchiamento (CARBONARA, 2000, p.545).

Ao considerarmos a realidade da restauração atualmente, percebemos a necessidade de uma maior consciência cultural.

\section{1. "Teoria do Restauro" de Cesare Brandi}

Como indicamos anteriormente, nos últimos 200(duzentos) anos, ocorreu uma consolidação da disciplina de restauro por meio de um processo de aprendizado maduro e coeso. E, através deste processo de amadurecimento, entendemos que a última consolidação de uma teoria da restauração arquitetônica ocorreu a partir da necessidade de escolher entre dois caminhos contraditórios e igualmente insatisfatórios: da reparação ou perda total dos centros históricos europeus, decorrentes dos efeitos extremamente penosos da Segunda Guerra Mundial.

[...] pouco se avançou nos últimos 40 anos no que se refere à teoria de restauração arquitetônica, embora se tenha progredido bastante no que 
toca ao desenvolvimento de uma metodologia cognoscitiva dos centros históricos e à criação de modelos de gestão dos mesmos, especialmente na Europa[...] (AZEVEDO, 2003, p.19).

É neste contexto que ocorre a retomada da discussão da problemática da restauração arquitetônica, trazendo novas questões e inovações expressivas, por meio das conferências em 1994 e 1996 no Japão e na Bulgária, onde aconteceu o debate sobre autenticidade e integridade do patrimônio cultural.

Contudo, os debates atuais não contemplam os critérios de intervenção em bens culturais notadamente arquitetônicos e urbanísticos, atendo-se, basicamente, ao caráter crítico-historiográfico sobre as conceituações e políticas patrimoniais. Conforme afirma Feilden (1982) no caso da conservação arquitetônica, surgem freqüentemente problemas porque a utilização do edifício histórico, que é economica e funcionalmente necessária, também tem que respeitar valores culturais.

Observamos esta realidade no preenchimento, em 2005, da lacuna ocorrida na praça Tiradentes em Ouro Preto (MG), resultado do incêndio no sobrado antigo onde funcionava o Hotel Pilão, em 2003. A variedade de critérios adotados neste tipo de restauração é ampla, e contraditoriamente é muito pequena a produção de estudos de caráter teórico e crítico sobre essas intervenções, resultando em escassas publicações sobre as restaurações, de maneira a gerar deficientes bases críticas sobre as intervenções de restauro arquitetônico e urbano no Brasil.

A insuficiência de tais debates críticos resulta em ambigüidades e graves lacunas quanto ao entendimento do conceito de restauração aplicado à arquitetura, que, em função de seu caráter utilitário, gera divergência entre vários críticos e teóricos de arte quanto à sua natureza de obra de arte, que a vêem como "meia- 
arte", conforme afirma Azevedo (2003). Buscamos, através de Brandi (2005), compreender que a funcionalidade na arquitetura representa caráter primordial, porém não é de natureza primária em sua restauração como obra de arte.

Amplos debates quanto à natureza artística da arquitetura, envolvendo os interesses de sua preservação, ocorrem com freqüência; entretanto, no que se refere ao tema da teoria da restauração, discussões da década de sessenta ainda são atuais. Estas reflexões, que resultaram do pós segunda guerra, geraram uma maior avaliação crítica do entorno e do monumento afetado pelas destruições, para então decidir-se o que pode ser feito diante dos danos provocados pela guerra.

Neste contexto, tais ações revelaram uma nova forma de ver a arquitetura da cidade, momento em que Cesare Brandi publicou os conceitos de sua Teoria do Restauro em um livro, que, de acordo com Carbonara (2002), traz nas bases de seu pensamento a confirmação de um sólido alargamento conceitual que manifesta, de maneira implícita, uma contribuição sistematizada e rigorosamente teórica de Alois Riegl.

Considerando a importância dos conceitos desenvolvidos por Brandi (2005), estudaremos sua Teoria, por se mostrar instrumento sólido para os debates críticos atuais quanto aos critérios de intervenção em bens culturais, e como apropriadamente afirma Azevedo (2003), por representar a última formulação teórica desta categoria que aborda o tema da restauração. Destacamos ainda que, de acordo como Carbonara (2006), na atualidade a linha "crítico-brandiana" é a mais adequada à preservação do patrimônio cultural. 
Enfatizamos, ainda, a importância da publicação em língua portuguesa, a partir de 2004, da Teoria do Restauro de Cesare Brandi, um trabalho da Beatriz Kühl para a ampliação dos estudos sobre o tema junto aos falantes de língua portuguesa. Entendendo a importância dos estudos de Brandi, introduzimos um olhar através de sua teoria, voltado para os bens culturais arquitetônicos, que traz neste universo a presença do espaço urbano, que possui caráter essencial em nossas pesquisas.

Observamos que, nos últimos anos, ocorreram em cidades tradicionais brasileiras número expressivo de intervenções com a denominação de requalificação, revitalização. Normalmente, essas intervenções são executadas pelo poder público, que busca um maior aproveitamento de áreas e regiões, implementando modificações das estruturas dos espaços urbanos por ele trabalhados, onde coincidem construções sobre o já construído, gerando uma nova configuração estética e funcional. E, em muitos desses casos, trata-se de espaços urbanos especialmente qualificados como obras de arte, por serem assim reconhecidos. Entretanto, revelam-se freqüentemente ações de intervenção sobre eles, sem o devido reconhecimento de fato (e não conceitual) de uma artisticidade inerente; por isso, o adequado tratamento do tecido figurativo da obra de arte não ocorre, propiciando aos monumentos danos irreparáveis.

Ações dessa natureza vêm acontecendo no Brasil, e podemos utilizar como exemplo o Programa Monumenta, que tinha como premissa básica, para realizar intervenções em bens culturais, que fossem reconhecidos como patrimônio mundial. Foram alteradas posteriormente suas normas, que passaram a contemplar cidades patrimônio nacional, sem o título de patrimônio mundial, e atualmente, com novas mudanças, têm em suas regras possibilidades de investimento em outras categorias 
patrimoniais, como foco de suas ações de preservação. Entretanto, ao se referir aos espaços urbanos, as intervenções deste programa vêm ocorrendo com deficiência, quanto à abordagem do entendimento conceitual de restauração. Está faltando uma busca adequada da relação com o espaço urbano, objeto de intervenções, em seu caráter estético e histórico.

Para melhor exemplificarmos deficiências como essas, destacamos o que Odete Dourado (2003) afirma em relação à perda devida ao incêndio do sobrado à praça de Tiradentes de Ouro Preto, em 2003.

[...] reconstruí-lo na sua aparência de casarão do século XVIII, mesmo com a utilização de materiais contemporâneos e simplificação formal - na tentativa velada de evitar um falso histórico - não camuflaria um atentado contra a arte: a sua expressão formal dificilmente fugiria do epíteto de pastiche, desqualificando a arquitetura contemporânea e fazendo empalidecer a antiga (DOURADO, 2003, p.13).

Se formos a Ouro Preto, hoje, encontraremos a lacuna do antigo casarão incendiado preenchida. A cidade e a praça, o ambiente como um todo, tiveram seus dados espaciais resgatados, ou mantidos, utilizando-se para isso a reconstituição de dados formais do monumento desaparecido. Surgem, então, várias indagações quanto à postura adotada diante da cidade reconhecida como bem cultural de relevância nacional e mundial, no que tange à sua condição artística e histórica.

A reconstituição formal, em 2005, do sobrado incendiado em 2003, privilegiou um determinado tempo histórico, e elaborou-se um pastiche. A partir de pesquisas e investigações, constatamos que na área atualmente ocupada pela nova construção, dentre os registros de ocupação, até o final do século XIX, no local do então casarão incendiado, na fachada para a praça Tiradentes, havia duas edificações: um sobrado com sete janelas no segundo pavimento; e seis portas no primeiro pavimento e uma 
casa térrea na esquina com duas janelas e uma porta. No século XX, conhecemos esses volumes modificados, de maneira que o maior incorporou o menor, passando a um único volume assobradado com dez janelas e dez portas. Agora, no século XXI, um sobrado foi reconstituído naquela área. Por que um sobrado, e não um sobrado e uma casa térrea? Ou por que não uma intervenção contemporânea?

As ilustrações a seguir retratam estes três períodos históricos, com suas diferenças formais. Acreditamos que o sobrado incendiado não seja uma construção do final do século de XIX, mas uma obra de ampliação de um sobrado existente a partir da eliminação da casa térrea, (Figura 1).

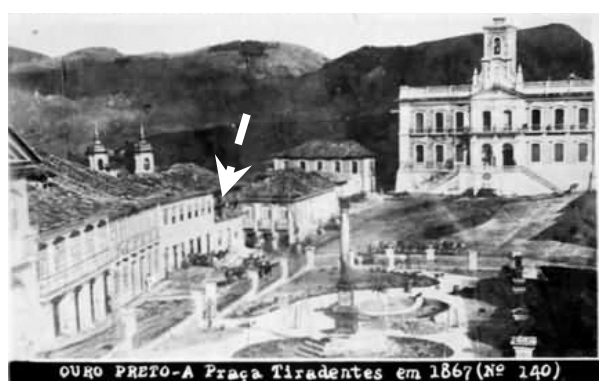

Figura 1. Praça Tiradentes, Ouro Preto, em 1867 - edificações onde era o Hotel Pilão Fonte:LAFODOC - EA UFMG (2006)

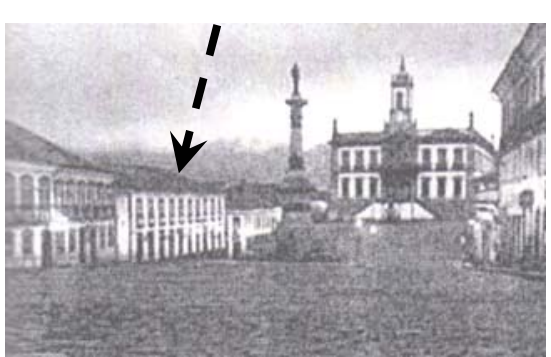

Figura 2. Praça Tiradentes, Ouro Preto - Hotel Pilão antes do incêndio.

Fonte: Dourado ( 2003).

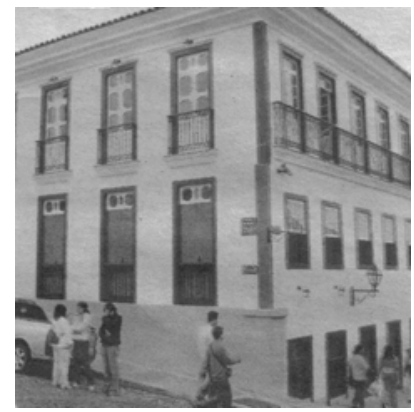

Figura 3. sobrado construído onde era 0 Hotel Pilão. 


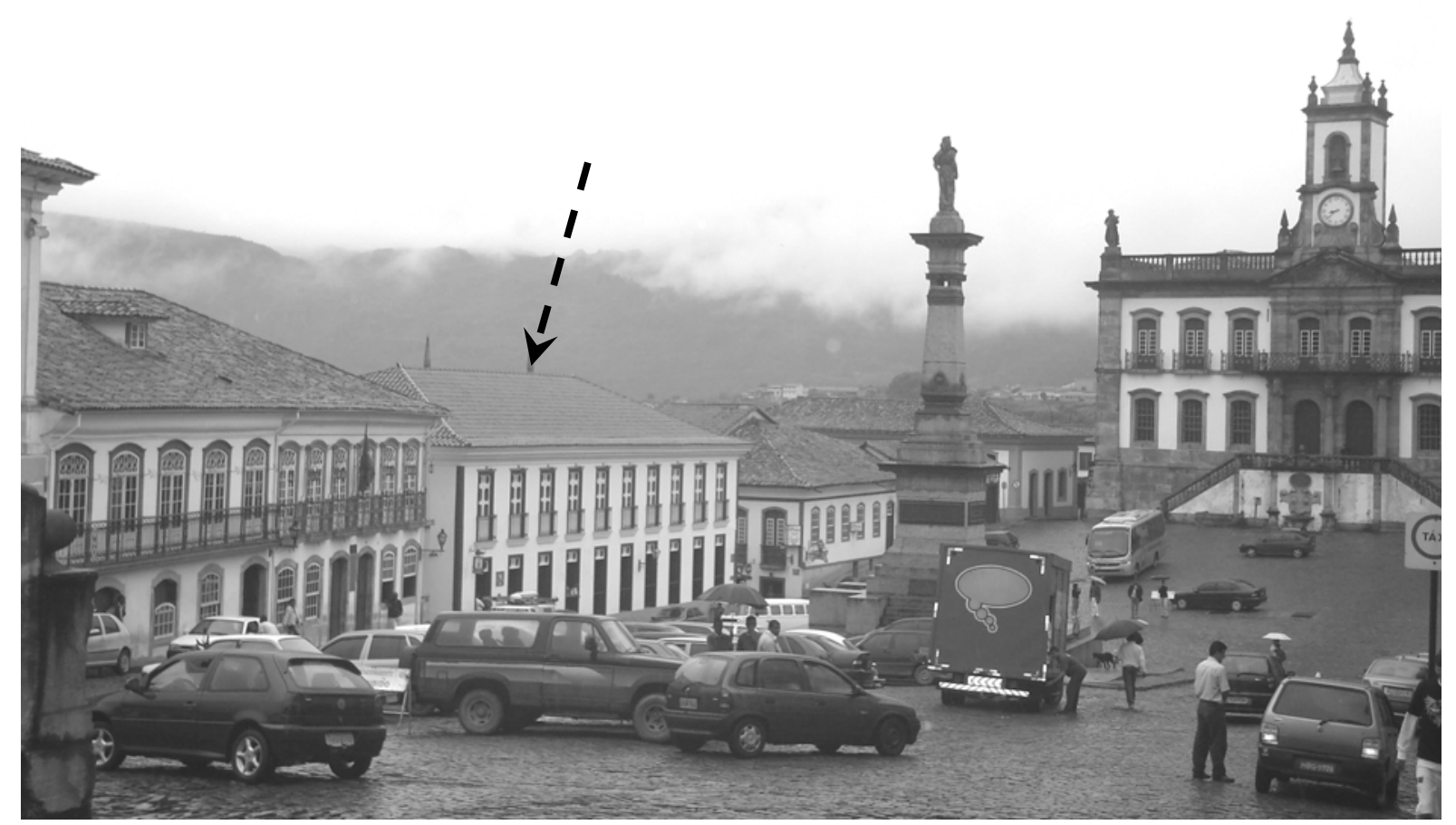

Figura 4. Praça Tiradentes, Ouro Preto, em 2007 - sobrado construído onde era o Hotel Pilão.

Analisando e estudando intervenções desta natureza, percebemos a importância de conhecermos o que é restauração e compreendermos o restauro urbano em sua possível implementação, pois o Brasil nem sempre reflete as concepções mais atualizadas do tema.

Azevedo (2003), notando essa deficiência brasileira no que se refere ao restauro, nos apresenta três tendências de recolocação do monumento frente à história. Para ele, a primeira, de caráter museificante, procura congelar o edifício com o auxílio das novas técnicas de consolidação estrutural, voltada para o anacronismo e para o passado. A segunda tendência foca o presente como síntese do passado, e procura integrar o monumento na vida contemporânea, flexibilizando seus usos e intervenções, introduzindo novos serviços e funções, para torná-lo 
viável e auto-sustentável. A terceira vertente, de caráter modernizante, tende a criar uma composição nova, voltada primordialmente para o futuro.

Em cada uma dessas posturas ocorre uma concepção distinta de patrimônio e de história; na maioria das vezes, refletem a ausência de linha conceitual unitária e coerente, percorrendo sensibilidades e gostos pessoais, gerando fragilidade e danos decorrentes do tipo de intervenção realizada.

Recorremos a Cesare Brandi (2005), para destacarmos que o restauro deve objetivar o restabelecimento da "unidade potencial da obra de arte", sem com essa recuperação cometermos uma falsificação artística ou histórica, de maneira a não apagarmos algum vestígio da passagem da obra de arte pelo tempo. Esse restabelecimento se torna o objetivo principal da restauração, a partir da Teoria brandiana. E sua importância é destacada por restauradores e pesquisadores; vários autores têm manifestado suas críticas ao tema da restauração, dentre eles Paulo Ormindo de Azevedo (2003), que afirma ser o restabelecimento da "unidade potencial" da obra de arte "o estado da arte do restauro hoje", e a grande questão da restauração atualmente é saber,

[...] o que se deve retirar e o que se pode introduzir para refazer a unidade potencial da obra de arquitetura e sua plena interação social, sem comprometer sua autenticidade ou eliminar as marcas de sua trajetória histórica e possibilidades futuras (AZEVEDO, 2003, p.22).

Acreditamos que a teoria desenvolvida por Brandi (2005) propicia fundamentos para esta discussão, por entendermos ser ainda a mais contemporânea Teoria que aborda a obra de arte quando de seu restauro. 
Para o professor arquiteto de teoria e história do restauro, Luigi Guerriero (2004), da Seconda Università degli estudi di Napoli, o século XX teve como momentos de expressão para a restauração Riegl, através de O Culto Moderno dos Monumentos, e Giovannoni, com a característica do restauro científico. A partir de então ocorreu uma ruptura do pensamento do restauro, representada pela Segunda Guerra Mundial, que fez surgir a urbanística da cidade histórica, e o restauro crítico com raiz neoidealizadora e fenomenológica. E é nesta linha que a teoria do restauro de Cesare Brandi se fundamenta.

Guerriero (2004) afirma que, após Brandi, somente no último decênio se iniciou um aporte de estudos que têm contribuído para a qualificação do restauro como disciplina autônoma voltada para a rigorosa conservação matério-figurativa do patrimônio cultural. Em sua Teoria de restauro, Brandi (2005) mantém sempre presente fundamentos filosóficos.

[Brandi possui] uma ascendência sempre kantiana, do idealismo e do espiritualismo de Benedetto Croce, em direção, no início, à fenomenologia de Edmund Husserl, e, depois, ao estruturalismo e também ao existencialismo de Jean-Paul Sartre, sem excluir, por fim, Martin Heidegger (CARBONARA, 2003,p.15).

Tendo como princípio que a Teoria brandiana é de caráter filosófico, buscamos compreender a fenomenologia em sua teoria, para melhor explorá-la. Para Brandi (2005) restauração é "o momento metodológico do reconhecimento da obra de arte na dúplice polaridade estética e histórica". Afirma que o reconhecimento da obra de arte como obra de arte "ocorre de modo intuitivo na consciência individual", e chega ao esclarecimento de que o momento metodológico deste reconhecimento se refere ao “... reconhecimento naquele momento do processo crítico em que, tão só, poderá fundamentar a sua legitimidade...”. Ou seja, segundo 
Brandi (2005) a conceituação de restauração, em sua fundamentação, está no próprio momento da manifestação da obra de arte como tal na consciência de cada um.

De acordo com o autor, é na imagem que a obra de arte se formula, não reduzida somente a uma função do conhecimento em meio da figuratividade desta imagem, pois nestas condições qualquer postulado de integridade orgânica se dissolve. Assim, ele afirma que "a imagem é verdadeiramente e somente aquilo que aparece: a redução fenomenológica que serve para indagar o existente torna-se, na Estética, o próprio axioma que define a essência da imagem" (BRANDI, 2005, p.44).

Buscando a relação com o restauro, verificamos que Brandi (2005) conclui que a manifestação, ou percepção da natureza, ou do significado essencial da imagem, é mostrada através da matéria e diz que

[...] deve-se definir a matéria, pelo fato de representar contemporaneamente o tempo e o lugar da intervenção de restauro. Por isso só podemos nos servir de um ponto de vista fenomenológico[...] (BRANDI, 2005, p.36).

Brandi (2005) esclarece que tal definição reflete um processo análogo àquele que conduz à definição de belo, "definível tão só pela via fenomenológica, como já o fizera a Escolástica: quod visum placet" (BRANDI, 2005). Ou seja, podemos entender que há uma experiência de contato direto com a verdade revelada, diante daquilo que agrada o olhar. A partir dessa realidade, percebemos que a fenomenologia ${ }^{1}$ faz parte das bases da Teoria do Restauro de Cesare Brandi, e que

1 Edmund Husserl fundou a fenomenologia na busca de que a filosofia tivesse as bases e a condição de uma ciência rigorosa, procurando dar raciocínio filosófico em relação às coisas variáveis do mundo real. Para ele, trata-se de um "método filosófico que se propõe a uma descrição da experiência vivida da consciência, cujas manifestações são expurgadas de suas características reais ou empíricas e consideradas no plano da generalidade essencial [Reconhecida como uma das principais correntes filosóficas do século XX, influenciou 
estabelece a importância dos fenômenos da consciência - os quais devem ser estudados em si mesmos - e que tudo que podemos saber do mundo resume-se a esses fenômenos, a esses objetos e idéias que existem na mente, cada um designado por uma palavra, que representa a sua essência, sua significação.

Os objetos da fenomenologia "são dados absolutos apreendidos em intuição pura, com o propósito de descobrir estruturas essenciais dos atos (noesis) e as entidades objetivas que correspondem a elas (noema)" (COBRA, 2005, p.1).

Com o auxílio dos preceitos filosóficos como a fenomenologia, Brandi (2005) vê um dos conceitos mais importantes para a restauração, "o conceito de imagem", dizendo que imagem é "exatamente o que aparece: a redução fenomenológica". Entendendo que a fenomenologia trata do estudo da consciência e dos objetos da consciência, a redução fenomenológica, segundo Cobra (2005) é "[...] o processo pelo qual tudo que é informado pelos sentidos é mudado em uma experiência de consciência, em um fenômeno que consiste em se estar consciente de algo", podendo se referir a imagens, coisas, fantasias, atos, relações, pensamentos, sentimentos e demais constituições de experiências da consciência.

Percebemos então que, para a fenomenologia, o mais relevante não é o que existe no mundo, mas, sim, o modo como o conhecimento do mundo acontece e se realiza para o indivíduo, onde a "redução fenomenológica" significa restringir o conhecimento ao fenômeno da experiência da consciência, importando prioritariamente a visão de mundo que cada um tem. Neste contexto, a percepção, 
assim como o pensamento, se faz nas coisas, considerando-se que pensar consiste em se reinstalar no ato da visão. Desta forma, de acordo com Merleau-Ponty (1999), a cada instante da existência estamos integrados ao mundo por meio de nosso corpo. Sendo esta a nossa condição, temos que reavaliar o fenômeno da percepção e perguntar como percebemos o mundo e, mais, devemos inquirir se podemos pensá-lo sem antes percebê-lo.

\section{Formulação conceitual}

Brandi se apresenta como um dos principais teóricos do chamado "restauro crítico", ao lado de Roberto Pane, Pietro Gazzola e Renato Bonelli. Essa vertente do restauro surgiu em meados da década de 1940, resultante do dualismo entre aspectos históricos e estéticos de uma mesma obra (KÜHL, 1998).

Brandi, em 1963, publica pela primeira vez a "Teoria del Restauro", uma síntese de sua produção textual, em processo de elaboração desde os anos de 1940, com discussões desmontando de imediato o conceito preestabelecido de que "restauração" trata de dar nova eficiência a qualquer produto da atividade humana. Na sua obra há ausência de destaque para Viollet-le-duc e Ruskin, pois mesmo se presentes, continua a existir a falta de citação referente a eles em suas exposições, 
assim como de Camillo Boito, Alois Riegl, Gustavo Giovannoni, dentre outros estudiosos do restauro.

O pensamento brandiano percorre caminhos diferentes daqueles tradicionalmente explorados pela conservação propriamente dita. Ele foi se solidificando fora do envolvimento inquietante que conjuga historicamente as sucessões de mudanças deste tema. Conforme esclarece Carbonara (2005) Brandi “prefere remeter-se, por princípio e por via dedutiva, diretamente à estética e à filosofia da arte, [ambas] investigada por ele de modo paralelo à restauração", a partir de cujas principais questões, sempre presentes na matéria, é proposta a Teoria do Restauro.

Carbonara (2005) sustenta que Brandi desenvolveu suas bases teóricas "com grande distância e soberana indiferença em relação ao debate especializado contemporâneo", e sua Teoria do Restauro gerou axiomas, entendidos por muitos como sendo ditados por uma lógica rigorosa. Devido a isto, recentemente, opositores de Brandi acreditaram encontrar motivos para considerar a Teoria brandiana superada, a partir da elaboração de críticas que com freqüência são interpretadas por seus seguidores como equivocadas. Entretanto, Giovanni Carbonara (2002) reconhece a contribuição de Brandi "entre as mais atuais formulações filosóficas", desde sua formulação até a atualidade.

As críticas contrárias à Teoria brandiana são fundamentadas no que concerne a construção teórica de Cesare Brandi, que se rompe caso seja negada a arte na "linguagem da consciência humana" (ou seja, em seus fundamentos filosóficos básicos), pois se isso acontecer, extingue-se no mesmo instante o "juízo de valor", 
que é o que realmente está apto a resolver a "dialética entre a instância estética e histórica" colocadas por ele como essenciais. É por esse caminho, portanto, que se sustentam as críticas atuais à Teoria do Restauro brandiana.

Os defensores da linha, conhecida como "pura conservação", defendem a ruptura do reconhecimento da obra de arte proposta por Brandi (2005), fragmentando sua estruturação conceitual, ou seja, as bases da fundamentação de sua Teoria do Restauro.

Contudo, Carbonara (2006) afirma que a união da Teoria brandiana com o pensamento do "restauro crítico" delineou novas perspectivas de desenvolvimento, estando assegurado que a Teoria se encontra na "linha mais correta e mais adequada à defesa do patrimônio cultural".

Brandi (2005) evidencia suas premissas básicas quanto à utilização da restauração quando se tratar de uma produção industrial, afirmando que "o escopo da restauração será evidentemente restabelecer a funcionalidade do produto". E, nesse sentido, desde as primeiras páginas de seu livro, ele já definiu a delimitação do que é restauro quando se tratar de obra de arte. Afirmando, ainda, que o restabelecimento da funcionalidade, caso seja o objetivo da intervenção de restauro em "obra de arquitetura e artes aplicadas [o restabelecimento da funcionalidade] representará, definitivamente, só um lado secundário ou concomitante, e jamais o primário e fundamental que se refere à obra de arte" (BRANDI, 2005).

Cesare Brandi (2005), em sua Teoria da Restauração, enfatiza que a característica peculiar das obras de arte está no fato de se tratar de um produto especial da atividade humana a que se dá o nome de obra de arte, "pelo fato de um 
singular reconhecimento que vem à consciência,... até que este reconhecimento que a consciência faz dele [do produto humano] como obra de arte, excetue-o, definitivamente do comum dos outros produtos". E essa exceção acontece, "pois neste momento ele começa a fazer parte do mundo, do particular ser no mundo de cada indivíduo. Portanto, é preciso apenas que se aceite a arte como um produto da espiritualidade humana" (BRANDI, 2005). Neste sentido, é preciso que não haja dúvida de que até que aconteça o reconhecimento da "obra e arte" como tal, ela é "obra de arte" apenas potencialmente.

Esta compreensão do significado da obra de arte é de fundamental importância para a Teoria brandiana, pois, por meio desse entendimento, Brandi (2005) estabelece que "qualquer comportamento em relação à obra de arte, nisso compreendendo a intervenção de restauro, depende de que ocorra o reconhecimento ou não da obra de arte como obra de arte" representando a espinha dorsal da sua Teoria do Restauro, pois a restauração somente é cabível em obras de arte - atualmente inserida no alargamento de bem cultural -, conforme nos esclarece Carbonara (2002).

No caso de uma restauração, a qualidade da intervenção estará estreitamente ligada ao juízo de "artisticidade" obtido a partir do comportamento em relação à obra de arte, do qual vem o reconhecimento da Teoria brandiana com a imposição da necessidade de articular o conceito de restauração não com base nos procedimentos práticos que caracterizam o restauro de fato, mas com base no conceito da obra de arte, de que recebe a qualificação, "ocorrendo, portanto, a ligação indissolúvel entre a restauração e a obra de arte, pelo fato de a obra de arte condicionar a restauração e não o contrário" (BRANDI, 2005, p.29). 
Brandi (2005) demonstra, portanto, que a ligação entre obra de arte e restauração se estabelece no ato do reconhecimento da obra de arte como tal, e é nesse reconhecimento que se encontram as premissas desta ligação, que tenderá a se desenvolver. Estabelecida então a relação entre obra de arte e restauração, Brandi (2005) define que "serão levadas em consideração não apenas a matéria através da qual a obra subsiste, mas também a bipolaridade com que a obra de arte se oferece à consciência". Comprovando que a obra de arte se coloca em uma dúplice instância: a instância estética e a instância histórica. Sendo a primeira "fato basilar da artisticidade pela qual a obra de arte é obra de arte", e a segunda, se refere à obra de arte "como produto humano realizado em um certo tempo e lugar e que em certo tempo e lugar se encontra" (BRANDI, 2005, p.29-30).

Constatamos que Brandi (2005) se preocupa em evidenciar o significado de obra de arte, esclarecendo que ela "é estruturada na consciência física e nas duas instâncias fundamentais [estética e histórica], na recepção que a consciência faz dela", pois tais definições são fundamentais para que ele possa enunciar o seu conceito de restauro, condicionado à devolução de uma relação direta com a obra de arte, a partir do seu reconhecimento como tal, definindo que:

restauração constitui o momento metodológico do reconhecimento da obra de arte, na sua consciência física e na dúplice polaridade estética e histórica, com vistas à sua transmissão para o futuro (BRANDI, 2005, p.30).

É definida por Brandi (2005) uma estruturação fundamental para o entendimento da obra de arte, na recepção que dela faz a consciência de cada indivíduo. E é a partir dessa capacidade para o conhecimento, sentimento e vontade, por meio da qual o ser humano se apercebe daquilo que se passa dentro 
dele ou em seu exterior, que derivarão os princípios para a atuação prática da restauração. A Teoria brandiana se define de maneira que passa a mergulhar em cada detalhe, organizando as diversas partes que a compõem solidamente. E nesse processo de reconhecimento da obra de arte como tal é que

a consciência física da obra deve necessariamente ter a precedência, porque representa o próprio local da manifestação da imagem, assegura a transmissão da imagem ao futuro e garante, pois, a recepção na consciência humana (BRANDI, 2005, p.30).

É por isso que no reconhecimento da obra de arte, o autor destaca a importância relevante do lado artístico, entendendo que é a partir desse reconhecimento que ocorre o objetivo da conservação para o futuro de uma possível revelação. Nesse sentido, a consciência física adquire primária importância, de onde é formulado o primeiro axioma da teoria do restauro brandiana, que diz:

"Restaura-se somente a matéria da obra e arte" (BRANDI, 2005).

Evidencia-se a clareza de que os meios físicos responsáveis pela transmissão da imagem são a ela simultâneos, gerando a afirmação: "não existe a matéria de um lado e a imagem do outro". Entretanto, tal coexistência não poderá manifestar-se por completo no interior da imagem. Conforme é apresentado por Brandi(2005) em sua Teoria do Restauro, parte destes "meios físicos" servirá de suporte para os "outros meios físicos" aos quais será confiada a transmissão da imagem propriamente dita (ex: fundações para a obra de arquitetura).

Segundo Brandi (2005), se as condições da obra de arte exigirem sacrifício de parte de sua consistência material, a instância estética será a primeira, prevalecendo 
sobre as demais, e deverá ser considerada como a mais importante, o que evidencia a especial relevância da artisticidade para a restauração brandiana, ressaltando que:

a singularidade da obra de arte em relação aos outros produtos humanos não depende da sua consistência material e tampouco da sua dúplice historicidade [do momento de sua confecção, e de seu presente], mas de sua artisticidade, donde se ela perder-se [seu caráter de obra de arte] não restará nada além de um resíduo. (BRANDI, 2005, p.32).

Brandi (2005) afirma, ainda, que não poderá ser subestimada a instância histórica, a qual possui uma dúplice historicidade: a que coincide com o ato da criação e se refere portanto a um artista, a um tempo e a um lugar, e a que provém do fato de insistir no presente de uma consciência, e portanto, uma historicidade que se refere ao tempo e ao lugar em que está naquele momento.

A partir de tais reflexões, Cesare Brandi (2005) atinge o que denomina "dialética da restauração", como sendo a disposição benéfica entre a instância estética e a histórica, exatamente "como momento metodológico do reconhecimento da obra de arte como tal". Como conseqüência desse avanço, ocorre a enunciação do segundo princípio do restauro de sua teoria:

\footnotetext{
a restauração deve visar ao restabelecimento da unidade potencial da obra de arte desde que isso seja possível sem cometer um falso artístico ou um falso histórico, e sem cancelar nenhum traço da passagem da obra de arte no tempo (BRANDI, 2005, p.33).
}

Considerando o que foi conceituado como restauração, por Brandi, destacamos a importância do entendimento do que é "matéria da obra de arte", por ser o que se restaura. E de igual importância o que o autor acredita ser "unidade potencial", por ser a que se dedica à restauração. Portanto, essas abordagens representam importantes estratégias para a restauração. 


\section{$\underline{\text { O que se restaura }}$}

O primeiro axioma da Teoria brandiana, premissa para uma restauração, diz que: "Restaura-se somente a matéria da obra e arte". E o que se entende por "matéria da obra de arte"? Brandi (2005) afirma que "na relação matéria e obra de arte, a matéria adquire uma fisionomia precisa, e é com base nessa relação que se deve definir o que é a matéria", ou seja, deve-se investigar aquilo que constitui a matéria com respeito à imagem (BRANDI, 2005).

Brandi (2005)nos propiciou analisar, até este momento, o que é obra de arte. Entretanto, para descobrirmos o que é a matéria, precisamos focar a relação entre "obra de arte" e "matéria", para então entendermos o que se deve restaurar. Nesse sentido, uma vez que a Teoria brandiana apresenta como único objeto da intervenção de restauro a "matéria da obra de arte", ocorre a exigência de um aprofundamento do conceito de matéria em relação à obra de arte, definida

\footnotetext{
pelo fato de representar contemporaneamente o tempo e o lugar da intervenção de restauro. Por isso, só nos podemos servir de um ponto de vista fenomenológico e, sob este aspecto, a matéria se mostra como aquilo que serve à epifania da imagem (BRANDI, 2005, p.36).
}

Essa definição nos deixa claro que, a partir "da percepção" do significado essencial da imagem, que representa um ponto de vista fenomenológico (conhecer por intuição psicológica), é que a matéria se mostra e representa o tempo e o lugar da intervenção de restauro. 
Continuando, Brandi (2005) afirma que, "a matéria como epifania da imagem dá portanto, a chave do desdobramento apenas esboçado e agora definido como estrutura e aspecto". Ou seja, a matéria como significado essencial da imagem possibilita a distinção entre estrutura e aspecto.

O conceito de matéria na obra de arte se insere "não de modo diverso, porém ainda mais inseparável do que aquele que é o verso e o recto para a medalha" conforme afirma Brandi (2005). O autor estabelece ainda que o fato de ser prevalentemente aspecto ou estrutura representa duas funções da matéria na obra de arte. Uma em geral não contradirá a outra, sem que com isso possa excluir um enfrentamento entre essas funções.

Semelhante conflito, como para a instância estética e instância histórica, só poderá ser resolvido com a prevalência do aspecto sobre a estrutura, quando não puder ser conciliado de outra maneira (BRANDI, 2005, p.36).

Brandi (2005) nos mostra por meio de tal conflito que sempre deveremos observar atentamente a "matéria da obra de arte" em sua bipolaridade de aspecto e de estrutura. Verificamos, com isso, que a compreensão da matéria, no desdobramento de suas duas funções, como significado essencial da imagem, resulta na revelação desta também em aspecto e estrutura, subordinando a estrutura ao aspecto (Figura 5 e 6). 

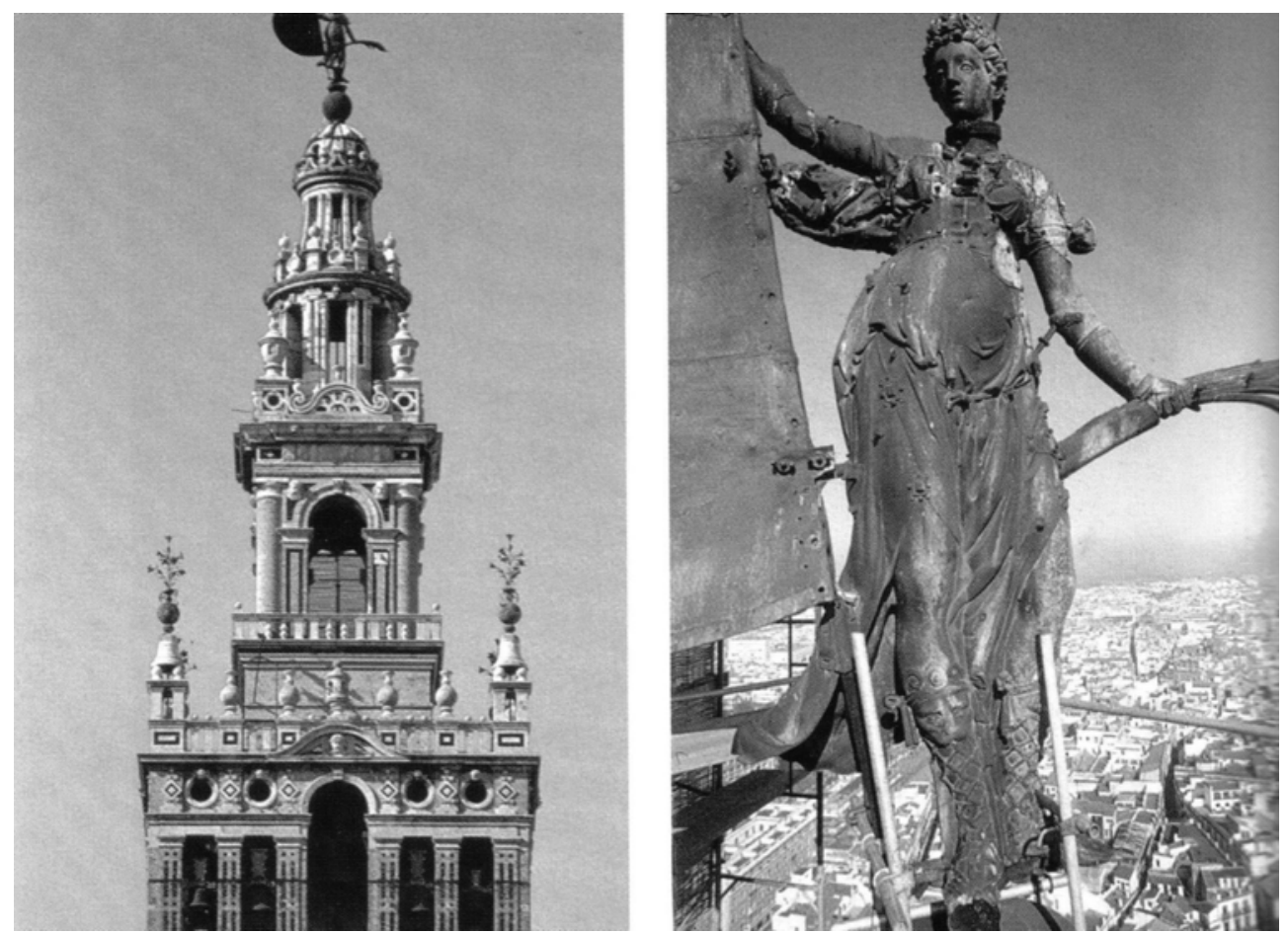

Figura 5. e Figura 6. Campanilha e Giraldillo da Catedral de Sevília - "estrutura e matéria como aspecto"

Fonte: Andaloro (2006)

Contudo, a distinção entre aspecto e estrutura é sutil e, para Brandi (2005) “nem sempre, para fins práticos, será de todo possível”. De onde verificamos que, de acordo com ele, "a matéria permite a manifestação da imagem e a imagem não limita sua espacialidade ao invólucro da matéria transformada em imagem" (Figura 5 e 6). Isso ocorre porque são ainda meios físicos de transmissão da imagem elementos intermediários entre o observador e a obra, como a atmosfera e a luz.

Uma vez que a matéria é o veículo de uma imagem, a sua estrutura pode ser alterada desde que não se repercuta no aspecto. Nesse sentido, saibamos que a matéria na obra de arte não se trata da matéria em sua concretude, pois “... sendo historicizada pela obra atual do homem pertencerá a esta época e não àquela mais 
longínqua, e por mais que seja quimicamente a mesma, será diversa..." (BRANDI, 2005, p.38).

É oportuno discutirmos o quanto são graves os equívocos decorrentes da não identificação das funções de aspecto e estrutura da matéria da obra de arte. Dentre tais erros Brandi (2005) apresenta os mais comuns, como: pensarmos que a matéria em sua concretude é a mesma matéria na obra de arte (mármore esculpido e o mesmo mármore na pedreira); pensarmos que a matéria é que determinaria o estilo; considerarmos o aspecto assumido pela matéria na obra de arte como função da estrutura; assimilarmos o aspecto à forma, mas dissolvendo a forma como matéria, ou seja, a matéria é veículo da forma, mas não é a própria forma (falta de reconhecimento da importância da matéria como estrutura); limitarmos a obra de arte à consciência material de que resulta a própria obra (ocorrem meios físicos de transmissão da imagem e/ou elementos intermediários entre a obra e o observador, como a qualidade da atmosfera e da luz); limitarmos a obra de arte à consciência material de que resulta a própria obra (BRANDI, 2005). 


\section{$\underline{\text { O que deve visar a restauração }}$}

O segundo princípio da "Teoria del Restauro" diz que "a restauração deve visar ao restabelecimento da unidade potencial da obra de arte" e, para definirmos os limites da restauração, devemos abordar o conceito de "unidade" desenvolvido por Brandi (2005). Para evitarmos dúvidas, o autor recomenda que seja verificado o quanto é indispensável que se atribua o caráter de unidade à obra de arte e, precisamente, a unidade que concerne ao inteiro, e não aquela que se alcança no total. De onde ele afirma que a obra de arte deve realizar "um inteiro" e não "um total".

O caráter de unidade é demonstrado, por exemplo, em um "mosaico", ou em uma construção arquitetônica feita de "blocos separados" e, por analogia, entendemos que esse caráter pode ser compreendido em edificações isoladas na cidade, onde percebemos a diferença entre os elementos reunidos em um total, ou conformados em um inteiro na construção da cidade enquanto obra de arte.

Considerando aceita para a obra de arte a "unidade do inteiro", Brandi (2005) afirma que se deve perguntar "se essa unidade não reproduz a unidade orgânica ou funcional como fundamentada de modo contínuo pela experiência".

$\mathrm{Na}$ imagem que a obra de arte formula, o mundo do conhecimento obtido por meio dos sentidos aparece reduzido tão só a uma função do conhecimento em meio da figuratividade, da representação de formas reconhecíveis da própria imagem 
(Figura 7). Entendemos que "qualquer postulado de integridade orgânica se dissolve, [pois] a imagem é verdadeiramente e somente aquilo que aparece: a redução fenomenológica que serve para indagar o existente torna-se, na Estética, o próprio axioma que define a essência da imagem" (BRANDI, 2005, p.44).
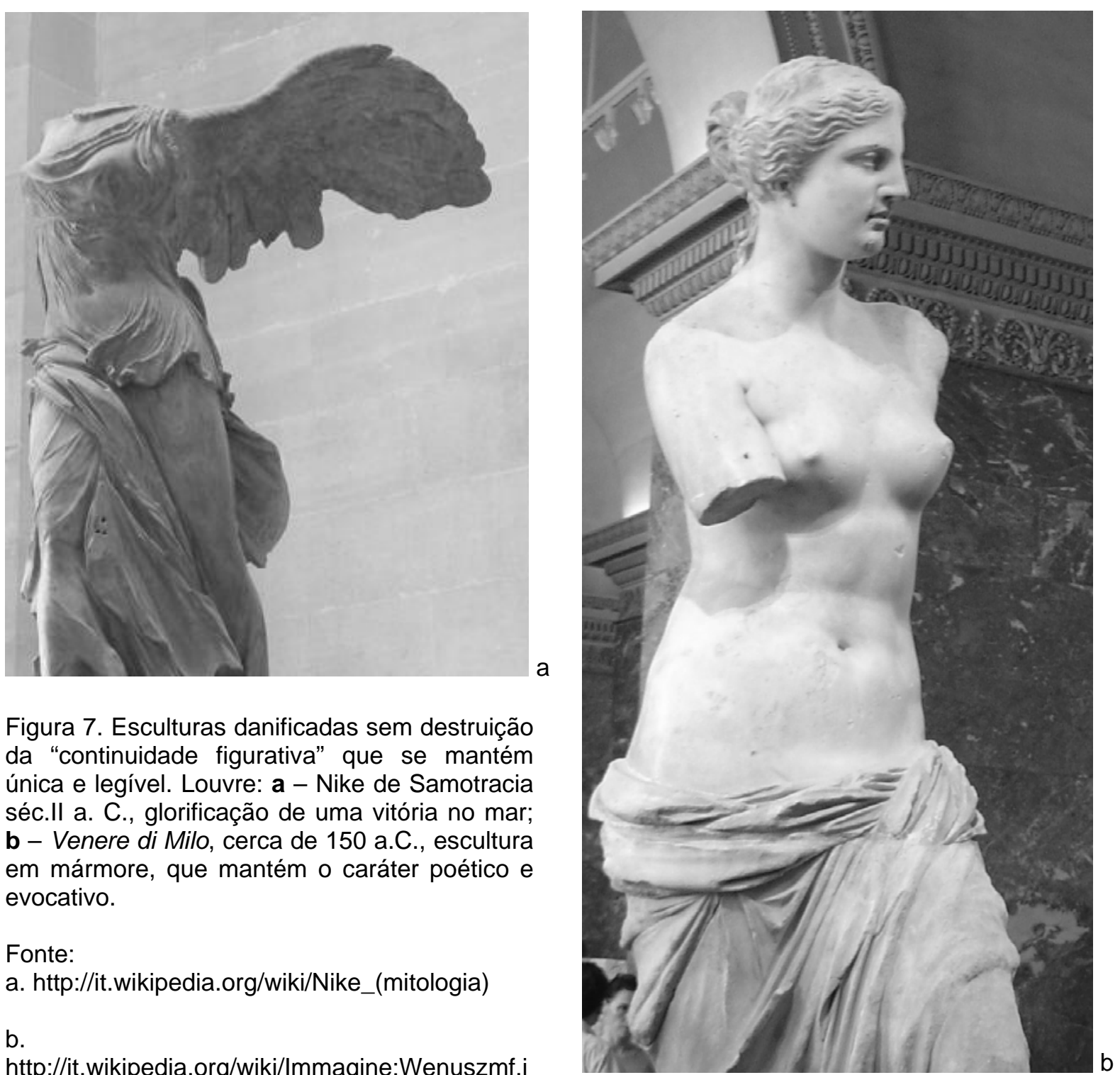

Figura 7. Esculturas danificadas sem destruição da "continuidade figurativa" que se mantém única e legível. Louvre: a - Nike de Samotracia séc.Il a. C., glorificação de uma vitória no mar; b - Venere di Milo, cerca de 150 a.C., escultura em mármore, que mantém o caráter poético e evocativo.

\section{Fonte:}

a. http://it.wikipedia.org/wiki/Nike_(mitologia)

b.

http://it.wikipedia.org/wiki/lmmagine:Wenuszmf.j $\mathrm{pg}$

Em conseqüência disso, a imagem de uma escultura em que se vê apenas o busto de um homem, com apenas o seu tronco, não pode por considerada mutilada, 
porque, na verdade, não possui corpo, "pois o que se vê é uma função semântica com respeito ao contexto figurativo que a imagem desenvolve" (BRANDI, 2005).

Isso nos faz perceber que a "unidade orgânico-funcional da realidade existencial" reside nas funções lógicas do intelecto, enquanto a "unidade figurativa da obra de arte se dá concomitantemente com a intuição da imagem como obra de arte" (BRANDI, 2005). A partir desse ponto, o autor entende que há duas proposições definidas para estabelecer os termos que regulam uma ação concreta de restauração: "a obra de arte goza de singular unidade pela qual não pode ser considerada como composta de partes; essa unidade não pode ser equiparada à unidade orgânico-funcional da realidade existencial" (BRANDI, 2005, p.46). Com esse encaminhamento dedutivo, o autor elabora a seguinte argumentação reflexiva:

\begin{abstract}
deduzimos que a obra de arte não constando de partes, ainda que fisicamente fracionada, deverá continuar a subsistir potencialmente como um todo em cada um de seus fragmentos e essa potencialidade será exigível em uma proposição conexa de forma direta aos traços formais remanescentes, em cada fragmento, da desagregação da matéria.

infere-se que se a 'forma' de toda obra de arte singular é indivisível, e em casos em que na sua matéria, a obra de arte estiver dividida, será necessário buscar desenvolver a unidade potencial originária que cada um dos fragmentos contém, proporcionalmente à permanência formal ainda remanescente neles. (BRANDI, 2005, p.46).
\end{abstract}

A partir desses dois corolários, podemos entender o que é a unidade potencial da obra de arte, de maneira mais clara. E compreender ainda a negação brandiana de que se possa intervir por analogia na obra de arte mutilada e reduzida a fragmentos. Em sua Teoria, o procedimento de analogia exigiria como princípio a equiparação da unidade intuitiva da obra de arte com a unidade lógica com a qual se pensa a realidade existencial. E isso é veementemente negado por Brandi (2005). 
Além disso, tal analogia produz ainda a ilusão de querer trazer a "salvação" da intervenção voltada a retraçar a unidade originária que,

desenvolvendo a unidade potencial dos fragmentos daquele todo que é a obra de arte, deve limitar-se a desenvolver as sugestões implícitas nos próprios fragmentos ou encontráveis em testemunhos autênticos do estado originário (BRANDI, 2005, p.47).

Figura 8. Figura de São Rufino e São Vitorino, restaurada e recuperada pelo ICR - Basílica Superior de São Francisco de Assis (IT)

Fonte: Andaloro (2006)

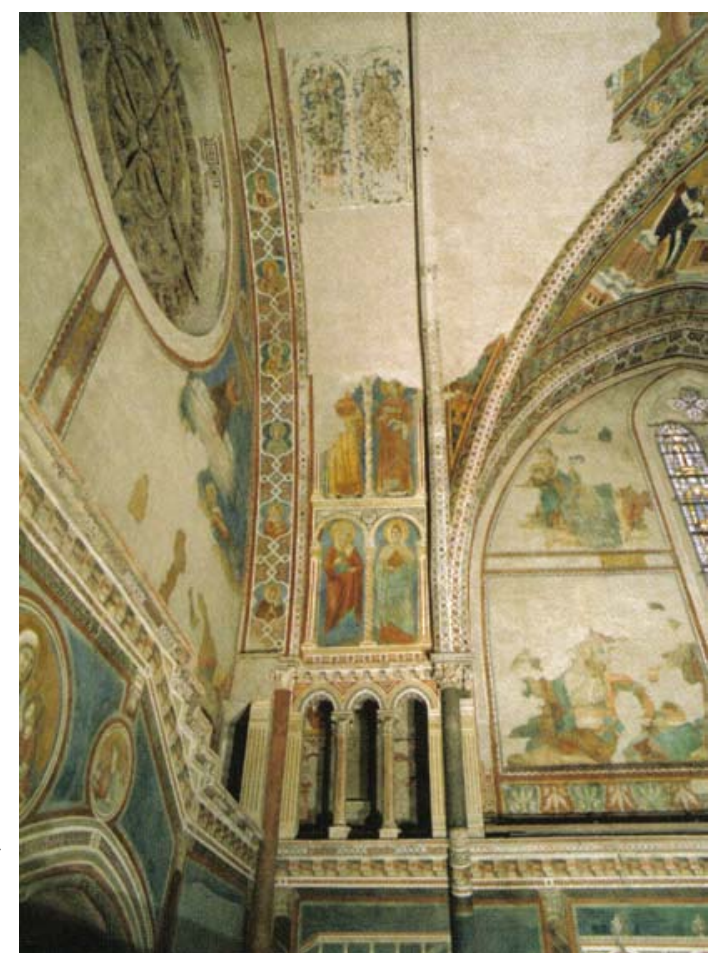

No desenvolvimento da unidade potencial, através desta "salvação" que se liga ao início do ato da restauração, são apresentadas as duas instâncias da obra de arte - a estética e a histórica - que evitarão a constituição de um falso histórico ou uma ofensa estética neste processo (Figura 8). A partir de tais reflexões, Brandi (2005) constrói dois princípios tidos por ele como práticos, mas não empíricos. 
O primeiro diz que "a integração deverá ser sempre reconhecível - mas sem infringir a unidade que se visa a reconstituir" (Figura 8, Figura 234 e Figura 235). Desse modo, a integração deve ser invisível à distância de que a obra de arte deve ser observada, e reconhecível de imediato, de perto, sem a necessidade de instrumentos especiais (BRANDI, 2005, p.47) - ver figura 230.

O segundo princípio diz que "a matéria de que resulta a imagem, é insubstituível só quando colaborar diretamente para a figuratividade da imagem como aspecto e não para aquilo que é estrutura" (BRANDI, 2005). A partir desse princípio, Brandi (2005) afirma que são contestados muitos axiomas da restauração dita arqueológica, que sempre em harmonia, prioritariamente, com a instância histórica, desenvolve maior liberdade de ação no que se refere aos suportes, estruturas portantes, dentre inúmeras outras abordagens.

Brandi (2005), em sua Teoria do Restauro, se refere ao que está por vir, ou seja, "prescreve que qualquer intervenção de restauro não torne impossível, mas, antes, facilite as eventuais intervenções futuras". Entretanto, para o autor, mesmo com as questões já discutidas e apresentadas, o assunto não está esgotado, porque permanece sempre em aberto o problema das lacunas. Segundo ele, é proibida integração fantasiosa, ou seja, a "substituição do elemento figurativo desaparecido com uma integração analógica" (Figura 9 e 10), pois esta é completamente diferente de um desenvolvimento da figuratividade do fragmento até que ele se una com o fragmento sucessivo.

lacuna, naquilo que concerne à obra de arte, é uma interrupção do tecido figurativo. Mas contrariamente àquilo que se acredita, o mais grave, em relação à obra de arte, não é tanto aquilo que falta, quanto o que se insere de modo indevido (BRANDI, 2005, p.49). 


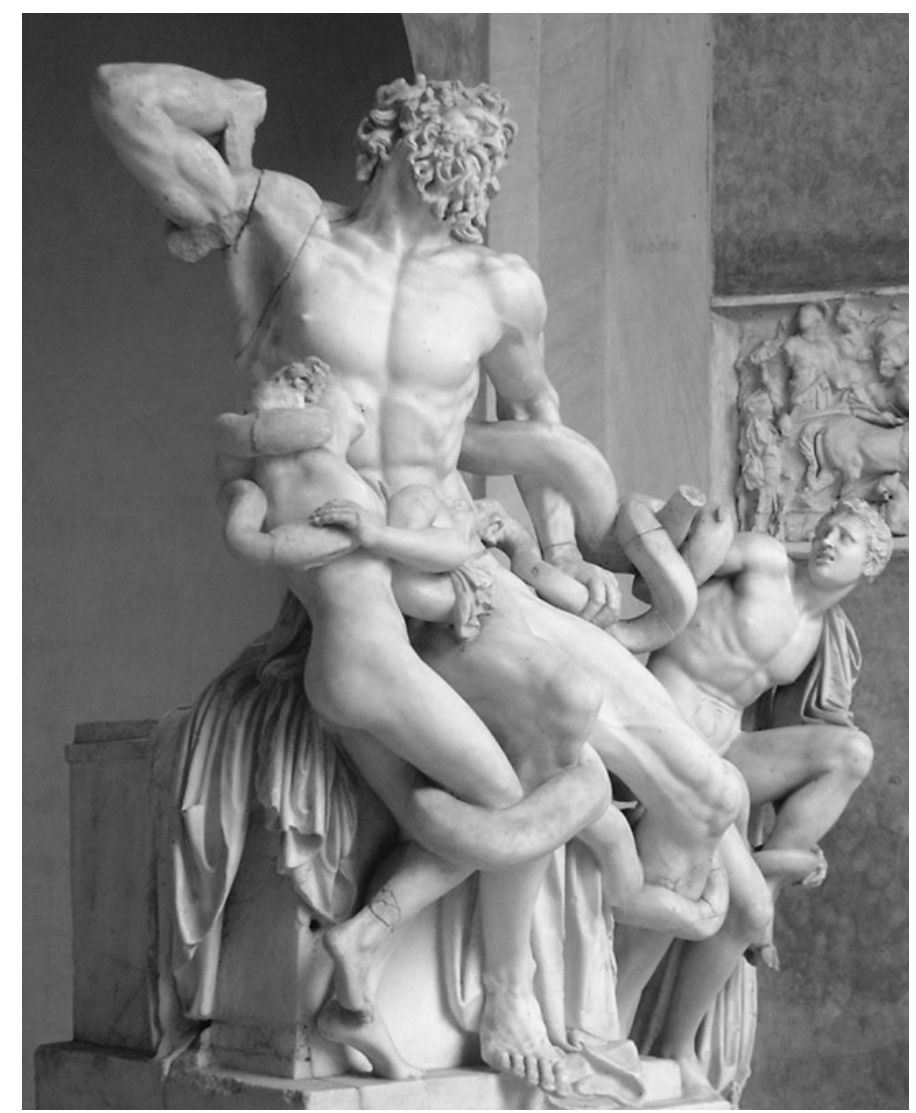

Figura 9. Laocoonte Museu do Vaticano - Roma. Situação em 1960 com o braço original, após a restauração de F.Magi

Fonte:

http://www.miti3000.it/mito/musei/louvre/louvre7.htm

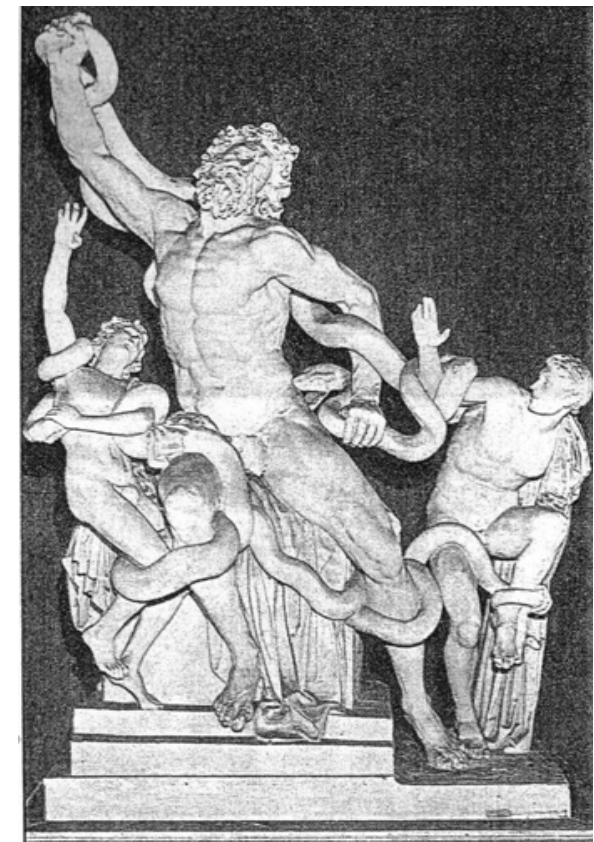

Figura 10. Laocoonte, situação da primeira obra de restauração em 1532, restauração fantasiosa

Fonte: Carbonara (1997)

Ou seja, a lacuna insere-se como "corpo estranho" no tecido figurativo da imagem da obra de arte. Para esse entendimento, Brandi (2005) recorre ao Gestaltismo no sentido de interpretar e neutralizar o sentido das lacunas, pois entende que a carga emocional e os conceitos estéticos são atributos de uma obra de arte e não do seu espectador (Figura 7). Ele afirma que a lacuna "coloca-se como figura, em relação a um fundo", e que na organização espontânea da percepção visual através de sua complexidade de interpretação instantânea, permanece a percepção que visa estabelecer uma imagem de figura e fundo. 
Dessa maneira, para Brandi (2005), quando ocorre mutilação de uma imagem, dá-se conta de que a dimensão da gravidade é de tal ordem que ocorre um retrocesso daquilo que nasceu como figura, pois agora passa a ser fundo.

É ainda através do Gestaltismo que Brandi explica o tratamento de lacunas que enfatiza a "camuflagem" da interrupção do tecido figurativo, causado pela lacuna, mas a postura deve ser no sentido de "fazer frutificar um mecanismo espontâneo da percepção" (BRANDI, 2005, p.51).

Compreendendo o que é obra de arte, matéria da obra de arte, unidade potencial, instância estética e instância histórica, dentro das abordagens brandianas, acreditamos que podemos então constatar que na teoria do restauro de Brandi, a instância estética impera em relação ao restauro através da reconstituição da unidade potencial, que representa especial estrutura da obra de arte como unidade, mas, sem a realização de um falso histórico, respeitando a essência da obra diante daquilo que a própria obra "indaga" ou "conduz". A partir de tais entendimentos, confiamos que seja possível caminhar rumo aos debates necessários para a verificação de um possível restauro urbano, buscando identificar como se pode perceber a matéria da cidade, e como ela pode ser vista como obra de arte. 


\subsection{O método formal}

De acordo com Mouldon (1997), morfologia urbana é um procedimento fundamentado em um processo organizado, lógico e sistemático de pesquisa, utilizado na análise das formas urbanas, que consiste no estudo da cidade como um "habitat humano", possibilitando a análise dessas formas a partir da identificação e detalhamento de seus vários componentes. Tais estudos revelam a materialização das idéias e das intenções que se estabeleceram nas cidades.

Tal maneira de se analisar as formas urbanas, denominada morfologia urbana, possibilita o entendimento de que a cidade pode ser "lida e analisada através de sua forma física". Esta análise pode ser estruturada em três princípios básicos: definição da forma urbana pelos elementos físicos fundamentais (edificações e seus espaços livres, áreas livres públicas e privadas, quarteirões, lotes e vias); compreensão da forma urbana decorrente das resoluções que oficializam a relação construtiva entre o edifício e o lote, as vias e as quadras, a cidade e a região; e compreensão da forma urbana a partir da história (MOULDON, 1997).

Podemos entender que essa leitura apresentada por Mouldon (1997) está fundamentada nos dados espaciais do universo urbano, compreendidos principalmente através da história, pois tais elementos espaciais estão sempre em processo de transformação e substituição. Com isso, percebemos que os dados 
formais da cidade não são os dados formais do edifício, ou do monumento. Os dados formais da cidade estão atrelados a seus dados espaciais.

Entendemos que a morfologia urbana permite analisar a relação existente entre os espaços livres, constituídos de ruas, praças, e os espaços construídos formados pelas edificações, materializados pela ação social. Neste sentido, torna-se importante o conhecimento de que esta relação decorre tanto da forma urbana, própria do lugar, como das normas e leis que ali incidem.

As bases conceituais da morfologia urbana têm sido abordadas de várias maneiras diferentes por seus seguidores. A partir dessas posturas distintas, a morfologia urbana se apresenta tendo como referência três correntes tidas como principais. E, através delas, são lançadas como ponto de partida, análises morfológicas através de "linhas" ou "escolas" de morfologia urbana, decorrentes da maior ênfase a determinados elementos conceituais do que a outros. Essas análises são realizadas após a descrição, caracterização e compreensão ou explicação das formas urbanas. Assim, as três correntes ou "Escolas de Morfologia Urbana", que representam linhas de investigação distintas, são conhecidas como escola inglesa, italiana e francesa (PEREIRA COSTA, 2004).

Nosso objetivo não é estudar tais escolas, mas conhecer suas principais diferenças e aproximações, para melhor compreensão dos instrumentos de pesquisa desenvolvidos por elas. Precisamos saber que, conforme esclarece Whitehand (1981), a "Escola Inglesa" ressalta o estudo da evolução das formas urbanas utilizando como parâmetro as modificações e transformações, tendo como objetivo estabelecer uma teoria sobre as construções das cidades, baseada nas 
transformações do parcelamento do solo e sistema viário. Disso resulta o entendimento da ocorrência de padrões semelhantes, que são identificados como "tipos" característicos de determinada forma urbana, que sobressaem em determinados períodos de tempo.

A "Escola Francesa" refere-se ao estudo que possibilita a análise da aplicação de teorias, como a avaliação da ação do movimento modernista sobre a forma urbana; a análise dos espaços livres, boulevard e praças, e de seu impacto nas formas urbanas (DARÏN², 2000, apud PEREIRA COSTA, 2004).

E a "Escola Italiana" de morfologia urbana, de acordo com Muratori (1959), enfatiza seus estudos entendendo que a forma urbana representa um modelo projetual para uma cidade, decorrente das análises de como as cidades deveriam ser traçadas, tendo como referência as tradições históricas das cidades italianas e sua relação com o espaço urbano. Podemos apontar, como importantes nomes dessa escola, Caniggia e Rossi. Neste sentido, torna-se importante para nosso estudo a afirmação de Lamers (2003) de que Rossi utiliza as teses urbanísticas de Camillo Sitte em suas análises da cidade, inclusive morfológica, apesar de conhecermos sua discordância com relação a Sitte na leitura global da cidade como obra de arte. Mas ainda assim, podemos perceber a referência de Camillo Sitte a essa escola, a partir do entendimento de suas análises da cidade antiga, reforçada pela influência em Rossi.

\footnotetext{
2 DARÏN, Michaël (2000). French Belts Boulevards. Apud PEREIRA COSTA, S.A. (2004). Transformações, conflitos, perdas e permanências na paisagem sul-metropolitana de Belo Horizonte. $315 f$. Tese (Doutorado) - Faculdade de Arquitetura e Urbanismo, Universidade de São Paulo, São Paulo, 2004.
} 
Para Cannigia e Maffei (2001), a "Escola Italiana" credita o aparecimento de núcleos urbanos à implantação de uma rota principal, a que outras rotas secundárias se conectaram, estabelecendo a malha viária que estruturaria a noção de região ou território. Desta estruturação - união entre rotas secundárias e principais apareceriam os núcleos urbanos. Ressaltamos que esse tipo de leitura é utilizado por Sylvio de Vasconcellos (1980), em suas análises a respeito do surgimento e evolução urbana dos núcleos urbanos setecentistas mineiros, conforme ilustra o esquema desenvolvido por ele, para Diamantina.

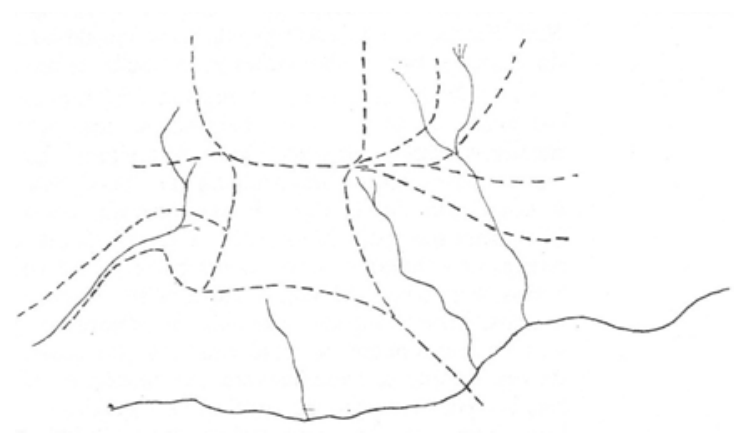

Figura 11. Diamantina - ligação entre Arrais periféricos

Fonte: Vasconcellos (1980)

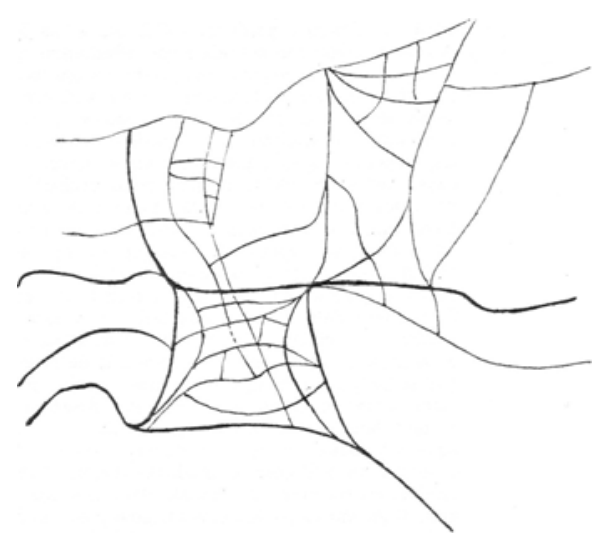

Figura 12. Diamantina - reticulado que compõe a parte urbana.

Fonte: Vasconcellos (1980)

Retomando a presença e importância de Camillo Sitte decorrente de sua pesquisa do espaço urbano, Françoise Choay (2001) baseada em estudos detalhados do livro "Der Städte-Bau nach seinen Künstlerischen Grundsätzen", afirma que Camillo Sitte é o "criador da morfologia urbana". Daí ocorre uma análise preliminar das disposições espaciais das quais as cidades antigas tiram a sua 
beleza. Para ela, Camillo Sitte recorre a um tratamento racional e sistemático da análise morfológica,

sob a diversidade das configurações espaciais para buscar regras ou princípios constantes no tempo que contém um conjunto de caracteres formais, comuns aos diferentes exemplos de espaços públicos antigos apresentados por Sitte: fechamento, assimetria, diferenciação e articulação dos elementos (CHOAY, 2001, p.185).

$\mathrm{Na}$ busca pela compreensão dos dados espaciais e materiais do espaço urbano, torna-se fundamental um amplo conhecimento das leituras de Camillo Sitte, que contemplam com igual importância os aspectos estéticos - e executados com arte - dos conjuntos urbanos. Tudo isso faz de Sitte o elemento de base de nossa leitura urbana, que percebe os aspectos artísticos e principalmente formais da cidade. Rossi (2001) entende que Camillo Sitte "procurava leis na construção da cidade que prescindissem dos fatos exclusivamente técnicos e se dessem plenamente conta da 'beleza' do esquema urbano, da forma tal como ela é lida". Sitte enaltecia as formas livres da organização antiga e medieval do espaço urbano: ruas, praças irregulares, que não surgiram na prancheta, mas ao natural.

O trabalho de Camillo Sitte em "A construção das cidades segundo seus princípios artísticos" compara plantas e efeitos em perspectivas de várias cidades. O autor traça uma espécie de história morfológica da arte urbana, que permite assinalar a diferença estrutural e o corte irremediável que separam as cidades do presente e do passado (CHOAY, 1980).

A retomada da percepção da importância do legado de Sitte, a partir da década de sessenta, tem trazido inúmeras contribuições às pesquisas e estudos do espaço urbano. Kohlsdorf (1996), em seu trabalho sobre leituras e percepção da forma urbana, utiliza Sitte e entende que ele aplica a "técnica de análise seqüencial, 
que procura representar a passagem progressiva do visto para o percebido, na sucessão de registros selecionados da composição morfológica de determinado lugar". O que representa, geralmente, o significado do comportamento imediato do indivíduo diante de uma obra de arte. Os estudos urbanísticos de Sitte são vistos pela autora como uma série de seqüenciamento de cenas.

Essa análise formal e estética da cidade, realizada por Camillo Sitte, traz até nós uma importante leitura, que evidencia a sua aproximação a um dos mais importantes teóricos da restauração. Nesta leitura, Ranellucci (2003, p.18) se refere a Viollet-le-Duc e Sitte quando ressalta que "le prime premesse al restauro urbano, nella sua opera Les Entretiens sur l'architecture, egli dedica parecchie pagine ad analisi e temi che solo una ventina d'anni più tardi saranno più compiutamente sviluppati da Camillo Sitte". E Choay (2001) afirma que "Sitte como Viollet-le-Duc viam na mise-em-scène o fundamento da arte urbana". A autora vê na análise morfológica sittiana uma "finura" que:

nos aponta a cidade, o centro ou bairro museais, e impõem-se como totalidades singulares; a morfologia, a malhas urbanas antigas, são monumentos históricos portadoras de calores artísticos e históricos bem como de valor pedagógicos de estímulos imaginados por Sitte e Viollet-leDuc (CHOAY, 2001, p.198).

Com isso, Françoise Choay possibilita a percepção, em Sitte, do estudo morfológico das cidades antigas, ou seja, a história e análise formal desses espaços urbanos, que representam para Camillo Sitte um instrumento inigualável de descoberta dos fatos urbanos. 


\section{A percepção da cidade por Camillo Sitte}

De acordo com Bresciani (2004), "o meio externo" e sua ação formadora do homem configuram a base dos argumentos sittianos. São de fundamental importância para a opção de estudo do espaço urbano, em sua natureza material, focado por Camillo Sitte.

Costa (2004) desenvolve um estudo sobre Camillo Sitte focando questões históricas e estéticas referentes ao processo projetual do urbanista. E aponta aproximações filosóficas em Sitte, o que nos possibilita compreender sua forma de percepção do espaço. Nesse sentido, Costa (2004) percebe que Sitte "não tem na estética apenas o locus do discurso do belo, que constrói seu projeto como um devir que reflete criticamente o presente a partir do passado, mas que mira o futuro". Esta leitura permite uma análise de Sitte em seus estudos para além da questão projetual, a partir de suas leituras referentes a diversas reflexões com objetivos variados. Consideramos relevantes os elementos apontados por Costa (2004), que acredita no entendimento que Sitte faz da Estética em sua obra, afirmando que:

\footnotetext{
Sitte parte da materialidade, isto é, das formas urbanas do tempo pretérito para elaborar "leis", "princípios" que conduzam, balizem a construção das cidades no presente. Nesse sentido, espaço e tempo, em Sitte, são as noções a priori que permitem o desenvolvimento da sensibilidade, da percepção. Estas possibilitam a apreensão não do númeno ou nomeno (da coisa em si), mas do fenômeno (como a coisa se apresenta a mim), permitindo "experiências" sensitivas, perceptivas, que possibilitam o conhecimento. Estas, por sua vez, o levam à formulação dos "princípios artísticos" que deveriam servir de "fio condutor" para "a construção das cidades" (COSTA, 2004, p.12).
} 
Não podemos deixar de esboçar aqui uma aproximação entre Camillo Sitte e Cesare Brandi, através dos fundamentos da fenomenologia, que faz parte das bases da Teoria brandiana, na percepção de uma obra de arte. O foco na materialidade, a sensibilidade na percepção das formas do objeto artístico e a maneira de seu reconhecimento apontam para nosso objetivo maior, que é a verificar possibilidade de um restauro urbano.

Tal sensibilidade sittiana para os estudos urbanos é apontada por vários pesquisadores, dentre eles González-Varas (1999), que percebe em Sitte a proposição de uma "visão pictórico-pinturesco da cidade, com escorços e perspectivas relacionadas às massas arquitetônicas que servem tanto para a reestruturação da cidade antiga como para a projetação da cidade moderna".

Desta maneira, uma vez que Choay (2001) aproxima Sitte de Viollet-le-Duc, e que Costa (2004) apresenta bases filosóficas que podem ser comuns entre Camillo Sitte e Cesare Brandi, e González-Varas (1999) evidencia a utilidade dos estudos sittianos para o tratamento da cidade antiga, podemos ampliar a percepção da importância de Camillo Sitte para os estudos e pesquisas de restauração que estamos desenvolvendo. Reforçada ainda por González-Varas (1999), que o aproxima de um dos mais importantes nomes do Restauro Científico, no que se refere a questões urbanas (Gustavo Giovannoni) quando afirma que "Giovannoni participa do aspecto da teoria de Sitte, que aponta as vantagens perspectivas que derivam da conservação da posição histórico-urbanística primitiva dos monumentos" (GONZÁLEZ-VARAS, 1999, tradução da autora). Cabe ressaltar o destaque que Ranellucci (2003) atribui a Camillo Sitte e a influência dele em Gustavo Giovannoni. 
Analogamente ispirata alla consapevolezza delle [Sitte] sistemazioni urbane del passato emerge, all'inizio del secolo successivo, la figura e l'opera di Gustavo Giovannoni (RANELLUCI, 2003, p.7).

Percebemos, a cada momento, a importância de Camillo Sitte em relação aos mais diversos temas da pesquisa que envolve os espaços urbanos. Conforme indica Choay (2001), Sitte não propõe copiar ou reproduzir os aglomerados urbanos antigos. Para isso, ele "recorre a um tratamento racional e sistemático da análise morfológica". E neste processo explora-se permanentemente o efeito perspectivo de limites espaciais irregulares (LAMERS, 2003).

Dentre os inúmeros destaques de Sitte para o nosso estudo, acrescenta-se de maneira relevante que, para o autor, "o 'urbanismo ruralizado' é privilegiado entre as formas urbanas históricas, porque é a mais longínqua e, portanto, a que com relação ao primeiro modelo fornecido pela natureza, menos alteração e perversões apresentará" (CHOAY, 1980). Isso representa uma característica marcante de nosso objeto de estudo, conforme veremos nos capítulos seguintes.

A leitura formal de Camillo Sitte ocorre "sob a ótica da psicologia da percepção do efeito estético das relações de proporções entre os edifícios monumentais e as praças [...]. A partir da fenomenologia, Sitte define uma tipologia de praça“ (LAMERS, 2003), que representa um sistema de praças fechadas nos tempos antigos. Para ele a questão primordial é definir as estruturas específicas de uma paisagem especial, construída de maneira tridimensional apresentando suas qualidades visuais e sensitivas.

Sitte (1992) afirma que "o senso artístico não consciente e natural" que sempre organizou os espaços urbanos é determinado ao mesmo tempo pelas 
normas transformadoras das culturas históricas e por uma organização mental estável. "O invariante, que deve permitir a formulação dos princípios e de leis universais utilizáveis para a elaboração do construído, situa-se então no domínio da psicologia" (CHOAY, 1980).

Camillo Sitte (1992) estuda o ambiente artístico da cidade em contra-ponto ao manual higiênico-sanitarista. O autor apresenta uma reação contra as tendências urbanísticas de seu tempo buscando dotar de bases artísticas o planejamento urbano. Ele "explica pela primeira vez de modo analítico as características de beleza das cidades históricas" (GONZÁLEZ-VARAS, 1999).

Disto resulta que a noção de ambiente artístico das cidades, em seu início um conceito evocativo, a partir dos esquemas de planificação de Sitte (1992), foi capaz de concretizar, no final do século XIX, um conjunto de técnicas de intervenção urbana.

Em Sitte (1992), ocorre uma análise preliminar das disposições espaciais de que as cidades antigas tiram a sua beleza. Ele descreve e explica, desde a cidade antiga até a barroca, como diferentes configurações do espaço não cessaram de irradiar beleza; a cidade antiga pode dar lições (CHOAY, 2001).

Utilizaremos desta percepção de Camillo Sitte (1992) para realizarmos uma leitura espacial do ambiente urbano, das formas urbanas em sua materialidade, para então, verificarmos a possibilidade de um restauro urbano a partir dos condicionantes apresentados por Brandi (2005) em sua Teoria do Restauro. Para isso, além de compreendermos os princípios sittianos, apresentaremos os procedimentos estabelecidos por ele, para realizar uma pesquisa de leitura urbana, 
a fim de posteriormente aplicá-los em nosso objeto de estudo no capítulo seguinte. E, assim, termos em evidência a matéria da cidade, que, em nosso caso, é também obra de arte, de que trata o restauro segundo Brandi (2005).

Para Sitte a mudança da cidade antiga para a contemporânea se deve a uma mudança de cultura, a uma transformação irreversível das mentalidades (SITTE, 1992). O autor vienense compara plantas e efeitos em perspectivas de várias cidades. Com seu método exaustivo, animado pela vontade de aprovar a coincidência dos fatos e da teoria, assinala um enfoque científico em seus estudos. Ele é um teórico da arte urbana e realiza análise morfológica (CHOAY, 1980).

A partir de leitura realizada por Camillo Sitte da parte para "o inteiro", é o fórum romano que ele designa como parâmetro principal, adota as regras estéticas da edificação; não aquelas da praça (medieval, renascentista ou barroca) ou da cidade antiga (LAMERS, 2003). Em Sitte (1992) a qualidade criadora do espaço urbano é mais importante que a forma arquitetônica, ressaltando-se, assim, seu caráter artístico.

\section{A cidade e sua constituição de acordo com Camillo Sitte}

Para Camillo Sitte (1992), o seu livro Der Städte-Bau nach seinen Künstlerischen Grundsätzen apresenta "a análise, sob um aspecto puramente técnico-artístico, de cidades antigas e de cidades modernas, com o intuito de pôr a 
descoberto os motivos de sua composição", e a partir desta proposta ele justifica que, analisando o todo, poderá buscar uma liberdade em relação ao sistema moderno de "bloco de edifícios" e, dentro do factível, realizar investigação "para nos resgatar da tendência ao aniquilamento das belas cidades antigas, ao mesmo tempo permitindo o florescimento de uma produção equivalente à dos mestres antigos" (SITTE, 1992, p.15).

Entendemos com isso que Camillo Sitte (1992) apresenta uma preocupação não somente com a construção das cidades, mas com a preservação daquelas ditas antigas. Ele circunscreve o estudo ao período da Renascença e do Barroco, focando os conjuntos urbanos e a disposição dos monumentos. É principalmente, desta preocupação pelo não aniquilamento das cidades antigas, que buscaremos tirar maior proveito dos estudos sittianos.

Sitte (1992) inicia a demonstração da necessidade do estudo das praças, afirmando que a praça da atualidade provoca interrupção da monotonia oriunda da grande quantidade de moradias e assegura uma visão mais ampla sobre um edifício monumental, fazendo sobressair seu efeito arquitetônico. O arquiteto faz um paralelo com as cidades antigas em que entende que nelas "as praças principais eram uma necessidade vital de primeira grandeza, na medida que ali tinha lugar uma grande parte da vida pública, que hoje ocupa espaços fechados, em vez das praças abertas" (SITTE, 1992, p.17).

Essa realidade evidenciada por Camillo Sitte no final do século XIX mantémse atual; entretanto, verificamos que ainda existem cidades antigas (neste caso consideremos uma analogia para o universo brasileiro, entendendo como "antiga" as 
cidades de origem colonial, por serem reconhecidas como as mais antigas do Brasil), que têm em suas praças eventos de destaques e até mesmo prevalência de uma vida pública ativa. E para o autor, por meio dessa dinâmica social, as praças podem adquirir a mesma leitura formal de um teatro, de um templo, de uma moradia. Tal reflexão é possível a partir do paralelo realizado, que traz às nossas análises as cidades brasileiras mais antigas, por meio das quais buscamos a percepção do emolduramento de um espaço descoberto, de uma praça, na realização de uma leitura formal, conforme indicada por Sitte (1992).

O arquiteto vienense demonstra que tanto o Fórum Grego, quanto o Fórum Romano apresentam forma fechada, com uma praça central, onde monumentos são dispostos ao longo de sua borda, concluindo que "o fórum está para a cidade inteira assim como para a casa de família está o átrio, a sala principal bem disposta e ricamente mobiliada" (SITTE, 1992). Ou seja, a presença da leitura estética é uma constante em Sitte, que traz para a realidade urbana o reconhecimento de sua natureza artística, através da analogia com espaços arquitetônicos reconhecidos e consolidados como tais.

Camillo Sitte (1992), convicto da importância da praça para a cidade, recorre a Pausânias para afirmar que "não pode chamar de cidade um lugar onde não existe praça e edifícios públicos". A visão do espaço urbano é apresentada pelo autor com uma importância minuciosa. Percebemos a dimensão desse envolvimento quando ele afirma que o ponto central de uma cidade está na "materialização da visão de mundo de um grande povo", a qual é possível com a transformação de uma obra em "obra de arte" ao longo dos séculos, onde a poesia e o pensamento são sublimes, condições em que, segundo Sitte (1992), se encontram o Propileu e Atenas. 
À medida que desvendamos Sitte, torna-se evidente a importância de seu legado. Neste sentido, quando em morfologia urbana se fala na influência de Sitte sobre Rossi, podemos observar que esta maneira de perceber o espaço artístico colocada anteriormente está presente em Aldo Rossi, quando ele apresenta suas leituras para identificação de um "fato urbano".

Essa aproximação possui especial importância para nós, na medida em que estudos de Rossi e Argan se aproximam em suas fundamentações teóricas, quanto ao consenso da cidade como obra de arte. Disto, podemos provocar uma reflexão a cerca de uma possível influência de Sitte sobre ambos, mas principalmente sobre Rossi. E, se considerarmos a aproximação entre Argan e Brandi e, se inserirmos Sitte, tendo em vista às possíveis influências de raízes kantianas em ambos, podemos ampliar nossos entendimentos e conjecturas referentes às bases para um restauro urbano de fundamentação brandiana.

Mas, para isso, precisamos identificar a materialidade da cidade através de Sitte, que deixa claro em seus estudos a importância em

\footnotetext{
esclarecer os aspectos artísticos desta questão [paralelo entre aspectos pinturescos das cidades antigas e as condições modernas], bem como identificar com precisão o que ainda pode ser resgatado em nosso benefício, das belezas destes conjuntos ao menos como patrimônio (SITTE, 1992, p.30).
}

Camillo Sitte (1992) destaca a importância das praças com características do "velho fórum", onde o significado público da vida urbana é mantido nas relações entre praças e edifícios monumentais. Com isso o autor evidencia as praças como sendo os principais pontos da cidade, por terem o privilégio de reunirem as construções que mais se sobressaem pelas suas qualidades artísticas. É nas praças 
que acontecem a efervescência urbana, a concentração do movimento, festas públicas, exibições, cerimônias oficiais, realização de eventos em geral.

Para Sitte (1992), de acordo com o tamanho da comunidade, ou tipo de administração da localidade, as necessidades de utilização dos espaços públicos abertos eram sanadas por duas ou três praças principais, pois, conforme afirma o autor, "as praças eram manifestação da diferença entre autoridade secular e autoridade eclesiástica". E, dessa diversidade surgiram padrões que foram imitados ou serviram como fonte de inspiração adequada a outros espaços. Para Camillo Sitte (1992) esses modelos independentes podem ser agrupados sob a seguinte estrutura:

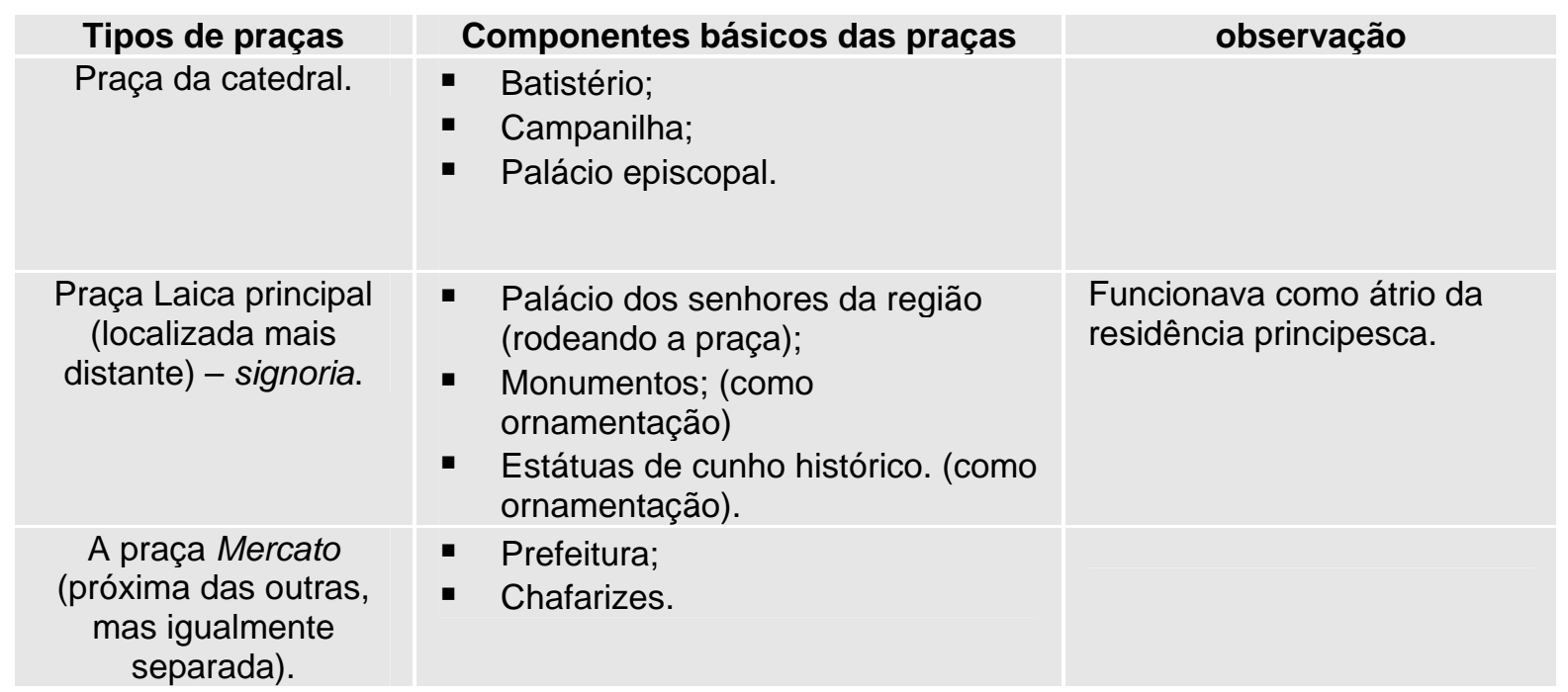

Figura 13. Composição dos modelos de praças por Camillo Sitte

Fonte: adaptado de Sitte (1992)

E, por analogia, podemos entendê-los no universo antigo brasileiro como praça da Matriz, praça do Pelourinho - com a casa de câmara e cadeira - uma de cunho religioso; a outra, administrativo, civil. 
De acordo com Sitte (1992), ocorria uma harmonização entre as praças antigas e os edifícios públicos contíguos. Apreendendo intelectualmente a praça como espaço urbano, o autor faz referência à praça "Piazza del Duomo" em Pisa, como representação de uma "verdadeira e pura obra de arte" enfatizando seus principais componentes como sendo a catedral, a campanilha (torre sineira), o batistério e o campo santo.

Para o autor vienense, a relação entre a praça e sua ornamentação deve ser atentamente observada, na busca por uma harmonia do espaço. É enfatizado por ele que as praças possuem espaços suficientes para as esculturas, e que os locais mais adequados para elas são as laterais junto aos muros, e não o centro, lembrando que no caso de uma praça irregular seu centro geométrico não pode ser definido, inviabilizando lugar para monumentos em seu centro, conforme pretende as propostas modernas (observar praças seiscentistas e setecentistas brasileiras).

O entendimento das minúcias de leitura do espaço urbano, de seus valores, das características de destaque espacial, ou seja, a exposição minuciosa da percepção da materialidade destes espaços estudados por Camillo Sitte (1992) nos exige um estudo e análise detalhada, pois pretendemos aplicar esses princípios morfológicos desenvolvidos por ele em nosso objeto de estudo para torná-lo evidente em sua matéria. Nesse sentido, procuraremos discutir o resultado do empreendimento de Sitte (1992) ao examinar a cidade, em uma transposição ao universo brasileiro.

No esforço de estudar o espaço urbano, Sitte (1992) analisa o Fórum Romano e as praças da Idade Média e Renascença, e conclui que, nele, o centro era livre, 
pois concernia aos gladiadores e não às estátuas, e que, quanto mais chegamos aos nossos dias, mais se torna freqüente a disposição de monumentos nos centros das praças.

cada lugar tem seu significado e sua história, e assim monumentos e chafarizes não se encontram nos principais eixos de tráfego, nem no centro das praças, mas estão ao lado de tudo isso (SITTE, 1992, p.37).

Para Sitte, a composição de uma praça varia de acordo com a cidade, com seu desenvolvimento histórico, pois são várias as desembocaduras de ruas e linhas de trânsito que geram pequenas áreas ou pontos intocados em cada praça. Camillo Sitte (1992), por uma questão natural, acredita que os monumentos devem ser colocados nesses pontos. Por meio desse sistema natural, observa-se a coincidência das exigências do trânsito e do efeito artístico, presentes nas praças.

aquilo que por um lado garante a liberdade das linhas de trânsito, por outro garante também a liberdade da linha de visão. Também se compreende com facilidade a ausência de monumentos obstruindo a vista sobre pórticos ou partes especialmente grandiosas de certos edifícios (SITTE, 1992, p.38).

De acordo com Camillo Sitte (1992), este entendimento para um centro livre é válido para o edifício; segundo ele, muitas vezes as igrejas acabam sendo colocadas no centro das praças, contrariamente ao jeito antigo. $O$ autor observa que antigamente as igrejas não eram construídas isoladas, representando uma relação de implantação de "um efeito sereno e expressivo".

Conforme lembra Choay (1980), Sitte realiza uma análise científica dos belos conjuntos urbanos do passado com o objetivo de extrair os princípios instauradores utilizados. Ele lê a posição das ruas em relação à praça, a forma da praça, a posição da igreja, e sua fachada principal em relação à praça e aos edifícios vizinhos. De acordo com Sitte (1992), em uma disposição antiga, os monumentos ficam nas 
bordas das praças, fato este ainda mais relevante no caso de obras arquitetônicas, “já que um edifício só estará em evidência e causará seu melhor efeito quando visto a partir de uma distância adequada em uma praça não exageradamente grande" (SITTE, 1992, p.42).

O autor aponta as desvantagens da implantação de uma igreja isolada em uma praça, em relação àquela ligada fisicamente a outras construções formando um único conjunto, pois "o isolamento significa a perda de todo o seu efeito".

Sitte (1992) chama a atenção para o "efeito harmônico" do conjunto quando igrejas e palácios estão encostados em outros edifícios, pois nessas circunstâncias ocorre um "fechamento rigoroso em relação ao espaço externo", como no fórum antigo, evidenciando "que um espaço vazio no meio de uma cidade se transforma em praça sobretudo devido a este fator".

Mas o autor enfatiza que "qualquer espaço vazio entre quatro ruas" não representa uma praça, uma vez que falta muito no que diz respeito à ornamentação, significado e caráter - como veremos no próximo capítulo, ao examinar a praça Dom Epaminondas em Serro (MG) -. Sitte (1992) faz uma analogia entre os aposentos mobiliados e vazios de uma casa, e as "praças mobiliadas" e "praças ainda não mobiliadas".

A partir deste conjunto de elementos concretos e abstratos, após observação atenta, chega à afirmação que "o mais importante e imprescindível pressuposto do efeito artístico" é o seu fechamento. 


Condição essencial
de uma praça
Fechamento do
espaço.

Condição para o fechamento de uma praça

- Estreiteza das ruas;

- Pouca necessidade de trânsito.
Exemplo de uma condição para o efeito artístico do fechamento.

Da massa de casas é recortado um espaço diante de um edifício monumental.

Figura 14. Meta para a eficácia artística de uma praça, por Camillo Sitte

Fonte: adaptado de Sitte (1992)

A Figura 14 mostra que, para o fechamento do espaço urbano, tido como essencial à sua boa estética, as características das ruas são importantes, inclusive sua dinâmica de circulação. E nesta leitura urbana, Sitte (1992) enfatiza a importância dos espaços livres (ruas e praças), mostrando a integração de edifícios semelhantes no ambiente das cidades históricas, de maneira que esses espaços permitam uma maior visibilidade dos edifícios monumentais.

[Em] cada ângulo da praça deve desembocar, à medida do possível, apenas uma única rua, e, se houver uma perpendicular, esta desemboca na primeira, mas bem adiante, onde já não pode ser vista da praça (SITTE, 1992, p.48).

Disso resulta que essas ruas desembocam em diferentes ângulos da praça, representando procedimentos conscientes ou intuitivos na construção urbana antiga. Para Sitte (1992), a qualidade criadora do espaço urbano é mais importante que a forma arquitetônica. Sob a ótica da psicologia da percepção, o efeito estético das relações de proporções entre os edifícios monumentais e as praças é apreendido a partir do efeito perspectivo de limites espaciais irregulares (conforme Figura 15).

Esta sensação física experimentada por Sitte (1992), interpretada através da experiência do espaço urbano, se aproximaria à de Cesare Brandi para a apreensão da obra de arte, enquanto conjunto urbano? 


\begin{tabular}{|c|c|c|c|}
\hline As ruas & As praças & $\begin{array}{l}\text { O conjunto de } \\
\text { edifícios }\end{array}$ & Observação \\
\hline $\begin{array}{l}\text { Orientadas } \\
\text { em forma de } \\
\text { pás de } \\
\text { turbina. }\end{array}$ & $\begin{array}{l}\text { - De qualquer ponto, } \\
\text { se tem uma única visão } \\
\text { fora dela; } \\
\text { - A coesão do contorno } \\
\text { parece contínua a partir } \\
\text { de qualquer ponto } \\
\text { dentro dela. }\end{array}$ & $\begin{array}{l}\text { - Possui uma } \\
\text { única interrupção; } \\
\text { - A perspectiva } \\
\text { garante a coesão } \\
\text { do todo. }\end{array}$ & $\begin{array}{l}\text { - ruas perpendiculares às } \\
\text { linhas de visão, e não } \\
\text { paralelas (segredo da } \\
\text { coesão); } \\
\text { - pode ser utilizado pórtico } \\
\text { encimado por edificações. } \\
\text { (coesão visual de uma praça); } \\
\text { - uma rua perpendicular ao } \\
\text { eixo de visão da praça, não } \\
\text { causa interferência em seu } \\
\text { fechamento e em seu efeito. }\end{array}$ \\
\hline
\end{tabular}

Figura 15. Resultado de reflexões sobre o espaço urbano ideal por Camillo Sitte

Fonte: adaptado de Sitte (1992)

Analisando as praças e seus edifícios prioritariamente sob o aspecto da forma, Camillo Sitte (1992) entende que se podem identificar atributos distintos e positivos de duas naturezas (praças de largura e de profundidade), o que faz uma praça sobressair em relação a outras (figura 16). 


\begin{tabular}{|c|c|c|c|c|c|c|}
\hline \multicolumn{3}{|c|}{ Tipos de praças } & \multirow{2}{*}{$\begin{array}{l}\text { Condicionantes } \\
\text { para os } 2 \text { tipos de } \\
\text { praças }\end{array}$} & \multirow{2}{*}{$\begin{array}{l}\text { Referencial para } \\
\text { o observador }\end{array}$} & \multirow{2}{*}{\multicolumn{2}{|c|}{$\begin{array}{l}\text { Resultado da leitura do } \\
\text { observador }\end{array}$}} \\
\hline & $\begin{array}{l}\text { Características } \\
\text { de cada tipo de } \\
\text { praça. }\end{array}$ & $\begin{array}{l}\text { Efeitos artísticos } \\
\text { de cada tipo de } \\
\text { praça. }\end{array}$ & & & & \\
\hline $\begin{array}{l}\text { de largura } \\
\text { (praça } \\
\text { curta). }\end{array}$ & $\begin{array}{l}\text { Edifício principal } \\
\text { deve ter maior } \\
\text { largura que } \\
\text { altura (caso das } \\
\text { prefeituras) }\end{array}$ & $\begin{array}{l}\text { - do tipo larga; } \\
\text { - dominada pela } \\
\text { fachada de um } \\
\text { palácio; } \\
\text { - grande ou } \\
\text { pequena. }\end{array}$ & \multirow{2}{*}{$\begin{array}{l}\text { - posição do } \\
\text { observador } \\
\text { (define o eixo } \\
\text { de visão da } \\
\text { praça); } \\
\text { - direção do olhar } \\
\text { do observador. }\end{array}$} & \multirow{2}{*}{$\begin{array}{l}\text { principal } \\
\text { edifício do } \\
\text { conjunto } \\
\text { (posição do } \\
\text { observador). }\end{array}$} & \multicolumn{2}{|c|}{ - identificação do tipo da praça; } \\
\hline $\begin{array}{l}\text { de } \\
\text { profundida } \\
\text { de (praça } \\
\text { longa). }\end{array}$ & $\begin{array}{l}\text { Edifício principal } \\
\text { localizado em } \\
\text { um dos lados } \\
\text { mais estreitos. } \\
\text { (dimensão do } \\
\text { edifício principal } \\
\text { similar à da } \\
\text { praça - maior } \\
\text { altura que } \\
\text { largura/ex:facha } \\
\text { da de igreja). }\end{array}$ & 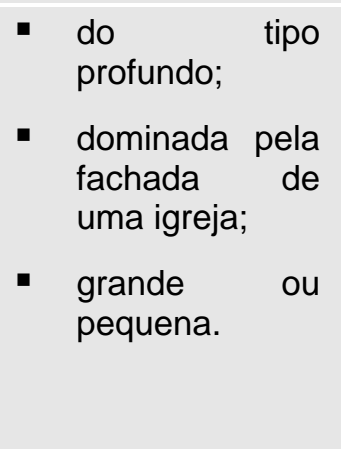 & & & $\begin{array}{l}\text { - percepção } \\
\text { das } \\
\text { construções } \\
\text { mais } \\
\text { importantes: }\end{array}$ & $\begin{array}{l}\text { - } \begin{array}{l}\text { sua } \\
\text { forma }\end{array} \\
\text { - suas } \\
\text { dimensões } \\
\text { - sua } \\
\text { ornamenta- } \\
\text { ção } \\
\text { figurativa }\end{array}$ \\
\hline
\end{tabular}

Figura 16. Cada um dos conceitos fundamentais do entendimento de praças por Camillo Sitte

Fonte: adaptado de Sitte (1992) 
Considerando de modo analítico a explicação das características de beleza das cidades históricas apresentadas por Sitte (1992), compreendemos a importância de sua investigação em praças antigas, uma vez que trata do estudo da "genuína obra de arte" que aponta para o descobrimento de novas belezas e novas sensações. Na opinião dele, o detalhamento que elaborou das categorias de praças não representa um "modelo puro", porque as praças possuem naturalmente a influência do "desenvolvimento histórico e das necessidades geradas por ele" (SITTE, 1992). Considerando a importância atribuída à instância histórica na obra de arte, podemos identificar uma aproximação entre Sitte e Brandi, quanto à percepção do objeto?

A partir de tais análises, entende-se que, assim como a forma, "também a dimensão das praças mantém uma relação proporcional com os edifícios que as dominam" (SITTE, 1992, p.57). E, para o autor, essa relação não é explícita, mas nitidamente perceptível.

Podemos descortinar em Sitte (1992) uma leitura fenomenológica para o espaço urbano, reforçada por uma possível influência kantiana, apontada por Costa (2004). Para Camillo Sitte (1992), uma praça muito pequena não permite a revelação do efeito total das construções monumentais que a compõem. E uma praça muito grande é pior ainda, pois uma construção monumental se tornaria diminuta em relação à praça. O autor se utiliza da percepção humana para alertar que não é possível que "recebamos a impressão de grandiosidade de uma praça na mesma proporção de suas dimensões reais", pois a percepção humana "não 
acompanha o ritmo de estímulos ininterruptos e crescentes, detendo-se em um certo momento" (SITTE, 1992, p.58).

Sitte apresenta seu entendimento de limite para o crescente efeito causado pelas dimensões das praças.

em uma praça pequena este efeito pode crescer consideravelmente a partir do acréscimo de alguns metros em sua largura; em uma praça grande, o aumento de suas dimensões seria pouco perceptível; e no caso de praças muito grandes se tem a perda completa da relação mútua entre a praça e os edifícios que a circundam, tornando-se indiferente à medida que ela aumenta (SITTE, 1992, p.58).

O autor evidencia a desvantagem de praças de dimensões exageradas (fazendo uma crítica às praças modernas) e esclarece que as proporções resultantes das dimensões de uma praça e dos edifícios que a circundam não podem ser definidas com precisão, pois estão sujeitas a oscilações freqüentes.

[...] na arte do espaço tudo depende das relações mútuas, e não das dimensões absolutas. [...] A relação entre os edifícios e as praças não pode ser definida com a mesma exatidão com que, por exemplo, os manuais determinam a relação entre colunas e travejamentos (SITTE, 1992, p.60).

Considerando sutilezas dessa natureza, trabalhando com sensibilidade a natureza artística e predominantemente estética dos espaços urbanos, Sitte (1992) traz a realidade reconhecidamente consolidada da arquitetura como obra de arte para o universo da cidade, do espaço público aberto. Esse esforço em demonstrar com clareza a artisticidade urbana gerou princípios verificados por ele a partir da percepção, apresentados pela leitura morfológica de praças (Figura 17). 


\begin{tabular}{|c|c|c|c|}
\hline $\begin{array}{c}\text { Praças } \\
\text { principais }\end{array}$ & $\begin{array}{c}\text { Dimensões das } \\
\text { praças } \\
\text { principais }\end{array}$ & $\begin{array}{l}\text { Dimensões dos } \\
\text { edifícios } \\
\text { dominantes }\end{array}$ & Observação \\
\hline $\begin{array}{l}\text { nas cidades } \\
\text { grandes - } \\
\text { são } \\
\text { maiores. }\end{array}$ & $\begin{array}{l}\text { muito maiores } \\
\text { que as praças } \\
\text { principais das } \\
\text { cidades } \\
\text { pequenas. }\end{array}$ & $\begin{array}{l}\text { a altura do edifício } \\
\text { principal (do nível } \\
\text { da praça à cornija } \\
\text { mais alta) é } \\
\text { proporcional às }\end{array}$ & $\begin{array}{l}\text { - para a praça de } \\
\text { profundidade a fachada } \\
\text { da igreja é proporcional ao } \\
\text { comprimento da praça; }\end{array}$ \\
\hline $\begin{array}{l}\text { nas cidades } \\
\text { pequenas - } \\
\text { são } \\
\text { menores. }\end{array}$ & $\begin{array}{lr}\text { muito } & \text { maiores } \\
\text { que as } & \text { demais } \\
\text { praças } & \text { da } \\
\text { cidade. } & \end{array}$ & $\begin{array}{l}\text { (medidas } \\
\text { perpendiculares à } \\
\text { fachada do edifício) }\end{array}$ & $\begin{array}{l}\text { a altura do palácio ou da } \\
\text { prefeitura, é proporcional } \\
\text { à largura da praça. }\end{array}$ \\
\hline
\end{tabular}

Figura 17. Princípios artísticos verificados para praças a partir da percepção por Camillo Sitte

Fonte: adaptado de Sitte (1992)

Destes princípios identificados por Camillo Sitte, observa-se que

a simples altura do principal edifício da praça, em uma aproximação grosseira, pode ser considerada como a menor dimensão possível para ela. Da mesma maneira, o dobro da altura do edifício corresponde à dimensão máxima da praça para que seja obtido efeito satisfatório (SITTE, 1992, p.60).

Sitte (1992) lembra que praças maiores aceitam edifícios menores desde que eles sejam desenvolvidos lateralmente, com poucos pavimentos. Para o autor a proporção entre a largura e o comprimento de uma praça é incerto, pois "tudo depende do efeito da perspectiva, e não do comportamento da praça em uma planta" (SITTE, 1992).

E, por conseqüência, este efeito natural depende da posição do observador. Percebe-se que, tendo em vista as limitações de visão do olho humano, "nossa capacidade de avaliação da profundidade é bastante inexata, de forma que a verdadeira relação entre a largura e a profundidade de uma praça atinge apenas parte de nossa consciência" (SITTE, 1992, p.61). 
Sitte (1992) chama a atenção para que percebamos que as praças quadradas não são bonitas, e que no caso das de profundidade, quando o comprimento é três vezes maior que a largura, o espaço começa a deixar de ser agradável. O autor vienense lembra que as praças de largura comportam maior diferença entre o comprimento e a largura, se comparadas com as praças de profundidade (mas deve-se levar em consideração as particularidades de cada caso).

Para Sitte (1992), o comum para qualquer centro de cidade é ser composto por um conjunto de praças junto aos edifícios importantes. Praças isoladas são exceção. Através das praças seqüenciadas, Sitte (1992) aponta para o vislumbramento de imagens urbanas distintas formando um conjunto harmônico e coeso a partir de um único monumento.

Esses efeitos de unidade devido à concordância do conjunto são possíveis a partir da construção de edifícios monumentais encaixados nas paredes das praças que devem ser fechadas. De acordo com Sitte (1992), "a notabilidade de uma praça pode ser encontrada através de sua forma, dimensão, de outras praças adjacentes, desembocadura de ruas, disposição de chafarizes e monumentos" (ex: praça Signoria, Florença). Para Camillo Sitte (1992), a beleza dos monumentos e suas implantações estão atreladas.

É destacado pelo urbanista vienense o efeito criado pelo movimento de uma praça na outra, dando como exemplo a praça de São Marcos, em Veneza, com suas praças adjacentes. 
a cada instante um novo conjunto pinturesco nos surpreende o olhar, e assim o efeito causado é sempre outro. Podemos verificar a riqueza de efeitos dessas praças em especial nas fotografias [...]. Fotografando-as [as praças] de várias posições, pode-se obter mais de uma dúzia de imagens diferentes, cada uma delas mostrando um outro quadro, de maneira que dificilmente acreditamos serem elas da mesma praça (SITTE, 1992, p.74).

Sitte (1992) esclarece que as suas análises têm como foco principal cidades italianas com referência à beleza clássica, e que os princípios de configuração das praças dessas cidades é diferente das do norte da Europa (Figura 18). Nestas, ocorrem outras exigências quanto a ruas e praças e "isto é válido tanto para a Itália medieval e renascentista, quanto para os países nórdicos" (SITTE, 1992, p.75).

\begin{tabular}{|c|c|c|c|c|}
\hline $\begin{array}{l}\text { Igrejas do } \\
\text { importantes ou }\end{array}$ & $\begin{array}{c}\text { norte } \\
\text { tedral) }\end{array}$ & \multirow{2}{*}{$\begin{array}{l}\text { Igrejas } \\
\text { do norte } \\
\text { (pequena } \\
\text { s) }\end{array}$} & \multirow{2}{*}{$\begin{array}{l}\text { Igrejas } \\
\text { barrocas } \\
\text { renascentista } \\
\text { s }\end{array}$} & \multirow[t]{2}{*}{ Observação } \\
\hline & $\begin{array}{l}\text { Condicionantes } \\
\text { para a } \\
\text { implantação }\end{array}$ & & & \\
\hline $\begin{array}{l}\text { - Implantaçã } \\
\text { o isolada; } \\
\text { - No centro } \\
\text { da praça; } \\
\text { - Circundada } \\
\text { s por vielas. }\end{array}$ & $\begin{array}{l}\text { Presença de } \\
\text { cemitérios }\end{array}$ & $\begin{array}{l}\text { Implantaçã } \\
\text { o } \\
\text { encaixada } \\
\text { em outros } \\
\text { edifícios }\end{array}$ & $\begin{array}{l}\text { Implantação } \\
\text { encaixada em } \\
\text { outros } \\
\text { edifícios }\end{array}$ & $\begin{array}{l}\text { - referência de } \\
\text { igreja isolada é } \\
\text { do gótico }\end{array}$ \\
\hline
\end{tabular}

Figura 18. Configuração de praças no norte da Europa, por Camillo Sitte Fonte: adaptado de Sitte (1992)

Examinando a tabela acima, percebemos as características das praças, com ênfase na implantação da arquitetura religiosa. Neste sentido, Sitte (1992) afirma que o posicionamento das igrejas antigas não coincide com o centro geométrico da praça circundada por vielas, mas está deslocado para a lateral. A regra antiga do não isolamento do edifício mais importante na praça é confirmada ainda mais no caso das prefeituras. Para o autor o efeito dessas praças "ainda é muito mais coeso em comparação às praças modernas, completamente abertas, que costumam não 
oferecer uma visão ampla, não havendo, sinuosidade nas ruas que as circundam" (SITTE, 1992, p.81). Ou seja, para Sitte a sinuosidade das ruas é um fato importante na coesão do conjunto urbano, pois Ihe possibilita ampla visão.

Esta abordagem do autor tem caráter essencial para percebermos a devida importância do papel das ruas no tecido urbano, mesmo que o enfoque principal de Sitte (1992), em seus estudos urbanísticos, seja as praças devido à sua plenitude artística e estética, conforme ele mesmo explica.

É digna de atenção a referência vinculada ao fórum antigo adotada por Sitte (1992) na leitura das praças: "não podemos distinguir entre uma disposição de praças tipicamente italiana ou germânica, mas apenas notar uma maior ou menor semelhança em relação ao fórum antigo". Essa postura reforça toda a linha esteticista adotada por Camillo Sitte (1992) em sua percepção do espaço urbano como obra de arte. Para tanto, ele utiliza, mais uma vez, de elementos consagrados em sua artisticidade, como o fórum antigo, para apresentar uma visão convincente do reconhecimento de ambientes da cidade em sua condição estética morfologicamente especial.

praças e ruas permaneceram alheias às mudanças de estilo, alterando-se apenas à medida que as construções no novo estilo [renascimento] ofereciam uma visão diferente sobre os edifícios circundantes (SITTE, 1992, p.84).

O autor entende que os edifícios do Renascimento eram constituídos de elementos que se tornaram decisivos para a definição da forma das praças, e "esta efervescência centrava-se no estudo dos efeitos da perspectiva no qual a pintura, a escultura e a arquitetura rivalizavam entre si". E, dessa inquietação do espírito, 
surgiram grande quantidade de disposições arquitetônicas e novos tipos de edifício com vistas à procura de melhores efeitos da perspectiva. Sitte afirma que estes novos efeitos foram incorporados à própria realidade.

foi assim que surgiram as grandes praças fechadas em três lados, diante de igrejas e palácios, jardins geométricos, panoramas e vistas de toda sorte; foi assim que desenvolveu o motivo tão fértil da rampa de acesso defronte às construções monumentais. $O$ espaço em forma de palco tornou-se o motivo principal de todas as disposições, tendo três lados fechados e um aberto correspondendo ao da platéia (SITTE, 1992, p.85).

Contudo, para o autor, o fechamento em três lados, que gera esta platéia deve representar um conjunto de edifícios coeso sem abertura de ruas laterais. Sitte (1992) adverte que a percepção de todos estes motivos foi gerada a partir da maturação das primeiras teorias sobre a perspectiva. Para ele sempre nos deparamos, dentro do material histórico, com "coisas significativas"; com a bela imponência das praças; com o refinamento da disposição do conjunto; com a composição de beleza e excelência de construções contíguas e adjuntas que ultrapassam o valor artístico dos próprios edifícios e monumentos. E "todo este novo mundo da construção urbana tem seu desdobramento mais fecundo nas obras do Barroco" (SITTE, 1992).

No barroco as praças eram utilizadas como átrio das grandes construções arquitetônicas de palácios e mosteiros, que eram constituídos por conjuntos de imponentes edifícios.

nos conjuntos barrocos tudo é ponderado de maneira conveniente, e a aparência das construções é decidida de antemão. [...] o aspecto mais forte do barroco está no cálculo dos efeitos de perspectiva e o engenho dos conjuntos de praças (SITTE 1992, p.87 e p.89). 
Apesar de o barroco divergir dos princípios básicos da antigüidade, para Sitte (1992) ele "alcançou um requinte muito particular na arte da construção urbana". Entendemos que esse requinte urbano está presente em nosso objeto de estudo (Serro), que faz parte do barroco mineiro.

Camillo Sitte (1992), apresentou a crítica básica à cidade moderna ao compará-la aos espaços antigos delimitados em seus estudos urbanísticos. Por essas análises, entende que a modernidade dissocia a construção urbana sob seus aspectos artísticos da história da arquitetura e das outras belas artes. Para Sitte (1992), a construção urbana na modernidade tem seguido caminho próprio indiferente ao que acontece a sua volta. O moderno traz a imitação como via a seguir, e realizou reconstrução de edifícios, ignorando as praças, reduzindo expressivamente o potencial artístico destes ambientes urbanos.

Assim, Sitte (1992) entende que na modernidade foram abandonados, até desaparecer por completo da memória, "todos os bons motivos artísticos da construção urbana". E, através da crítica à atitude daqueles que transformam a cidade em sua contemporaneidade, ele declara que "hoje, quase ninguém mais se ocupa da construção urbana enquanto obra de arte, mas apenas enquanto um problema técnico" (SITTE, 1992, p.94).

Esta afirmação se mantém contemporânea; passaram mais de 100 (cem) anos e os entendimentos de Sitte (1992) continuam atualizados a cada dia. Conforme nos esclarece Ranellucci (2003, tradução da autora) o interesse de Sitte não é voltar ao passado enquanto tal, mas ao contrário disto, sua "leitura do 
passado resulta num início de classificação, voltada para uma pesquisa absolutamente atual, denominada 'invariável'”. Conforme é relacionado por Sitte (1992) em padrões de praças (Figura 19 e 20).

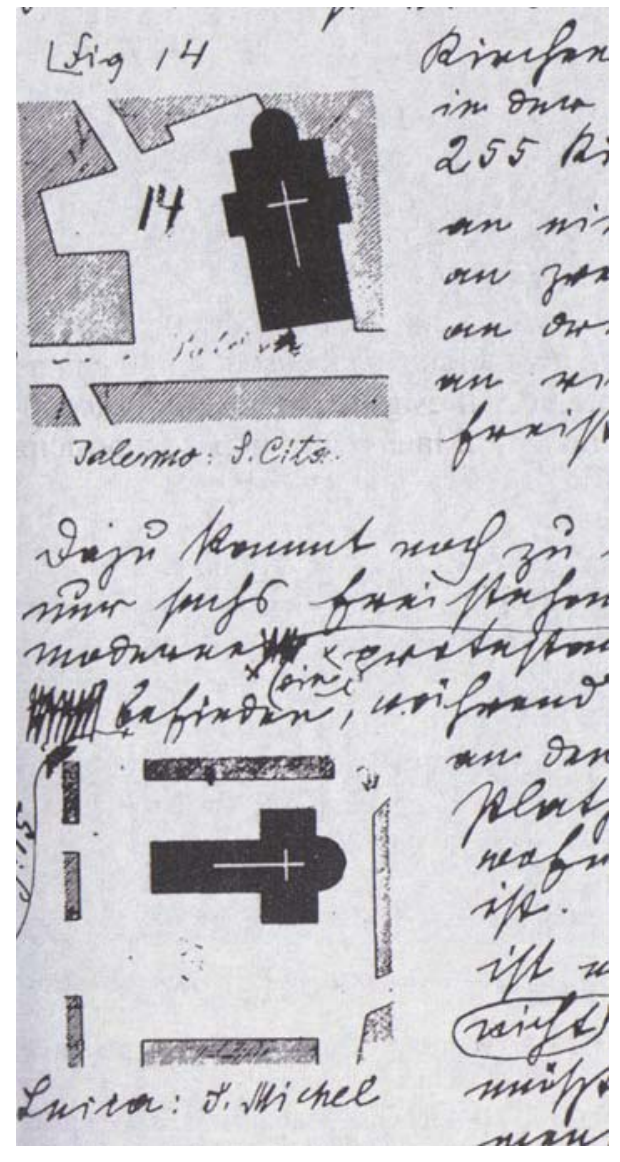

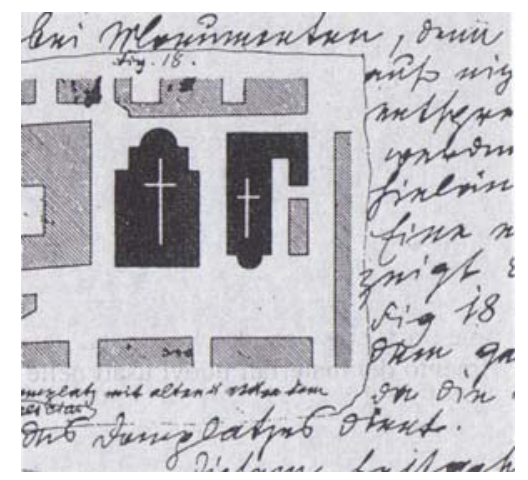

Figura 19. Cita, Palermo. São Michele, Lucca. Estudo de praça e sistematização urbana - manuscrito de Camillo Sitte Fonte: Ranellucci (2003)

Figura 20. Brescia, Praça do Duomo - manuscrito de Camillo Sitte

Fonte: Ranellucci (2003)

Os estudos de Camillo Sitte (1992) possibilitaram-Ihe realizar críticas à modernidade que foram, em muitas situações, mal interpretadas, como a famosa divergência conceitual publicada por Le Corbusier, quanto à característica das ruas, por exemplo. Cabe enfatizar que, para Camillo Sitte (1992), linhas e ângulos retos representavam de fato características de cidades frias quanto à sensibilidade 
estética, mas não é esse o aspecto de maior negatividade aos espaços modernos, uma vez que "conjuntos barrocos também eram constituídos por linhas e ângulos retos, sem que isso fosse um obstáculo para a obtenção de efeitos imponentes e genuinamente artísticos"(SITTE, 1992, p.95). Neste sentido, o autor vienense destaca o que acredita ser de fato danoso aos espaços urbanos apresentados até então pela modernidade.

a principal causa da total impossibilidade de um efeito coeso no conjunto urbano [moderno] é a interrupção contínua das ruas por perpendiculares muito largas, de maneira que, tanto à esquerda quanto à direita, nada resta além de uma série de blocos isolados de edifícios (SITTE, 1992, p.96).

Para o autor, a configuração do espaço deveria trazer como impressão conveniente ao resultado de um todo coeso, a partir de uma conseqüência baseada na continuidade, acompanhando a silhueta de uma rua inteira ou circundando uma praça, de modo a lhe conferir uma forma encerrada. O espaço "vazio" da cidade antiga, como ruas e praças, de acordo com Camillo Sitte "formava um todo coeso e de efeito calculado", diferente da atualidade onde a massa edificada é que define o que vai sobrar para as ruas e praças. Para o autor o efeito estético destes espaços públicos é especial, de maneira que "a irregularidade das praças antigas enganam o olhar, sendo percebidas apenas em suas plantas, mas jamais na realidade" (SITTE, 1992, p.98).

Em seu exame racional dos espaços modernos, Sitte (1992) entende que existem sistemas que caracterizam a construção urbana, como o "sistema retangular", "sistema radial" e "sistema triangular". Para o autor, eles possuem como propósito a regularização do traçado das ruas, representando um "objetivo técnico e 
não artístico". A partir das análises dos sistemas modernos, Sitte (1992) apresenta uma leitura conforme Figura 21.

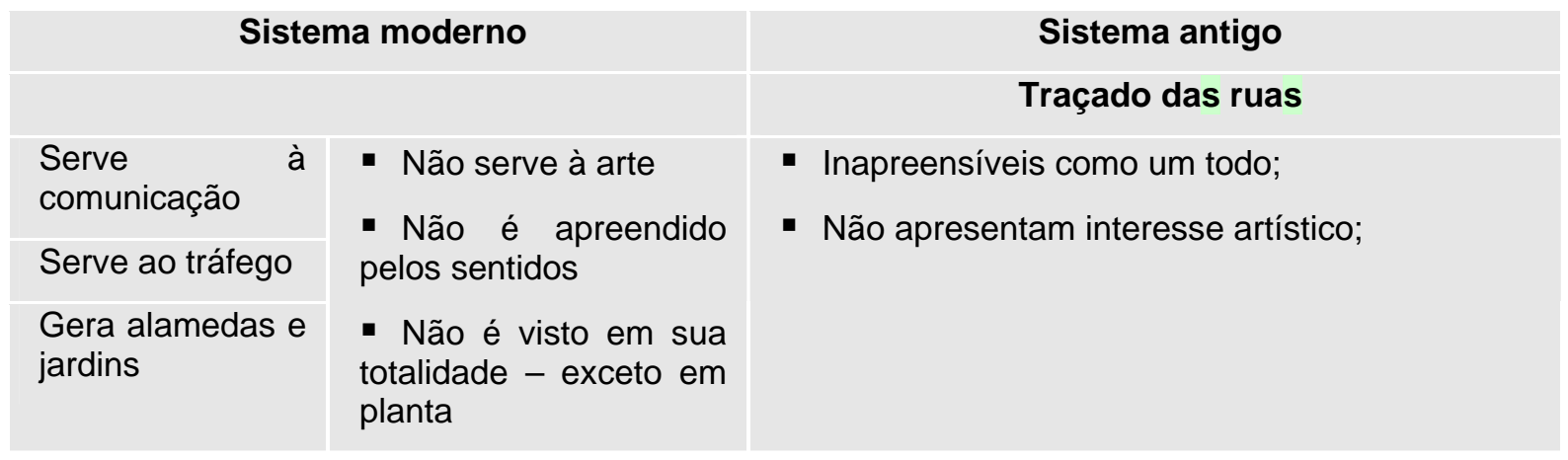

Figura 21. O sistema viário moderno e antigo, por Camillo Sitte.

Fonte: adaptado de Sitte (1992)

Observando o quadro acima, cabe-nos chamar atenção para o fato de que segundo Sitte (1992), "o traçado das ruas" (no plural) não apresenta interesse artístico, contudo, considera de grande valor a artisticidade de uma única rua (no singular), pois afirma que "artisticamente relevante só é aquilo que pode ser visto como um todo, ser apreendido em sua totalidade - portanto uma única rua, uma única praça" (SITTE, 1992, grifo nosso). Para o autor, é possível que se tenha a totalidade de uma via inteira, mas não de um traçado viário(sistema). Entretanto, Sitte (1992) analisa como esteticamente essencial também a seqüência de praças, como vimos anteriormente. Nesse sentido, acreditamos que a colocação do autor referente ao caráter individual de cada um desses elementos (praças e ruas) diz respeito ao que, de fato, é relevante para ele no momento. Ou seja, o mais importante e de destaque deve ser o relativo ao "um - único" (uma rua, uma praça) em detrimento "do conjunto" (várias ruas, várias praças). Acreditamos existir, neste caso, flexibilidade quanto às leituras e percepção do espaço urbano, pois para as 
praças (mais de uma, ao se referir a um seqüênciamento), são possíveis o reconhecimento de seu valor estético e a apreensão como um todo.

Para Rossi (2001), Sitte entende "que a cidade como obra de arte seja redutível a qualquer episódio artístico ou à sua legibilidade e não, afinal, à sua experiência concreta". A isso Aldo Rossi se contrapõe acreditando que, naturalmente, deve-se observar esta arquitetura total por partes, mas

o todo é mais importante que cada uma das partes; e que apenas o fato urbano na sua totalidade, portanto também o sistema viário e a topografia urbana até às coisas que se podem apreender passeando de um lado para o outro numa rua, constituam esta totalidade (ROSSI, 2001, p.52).

Entendemos que Rossi não nega Sitte, mas acrescenta o evidenciamento da importânica de fatores como a topografia e o sistema viário na percepção do espaço em sua totalidade. Se, para Sitte (1992), "artisticamente relevante só é aquilo que pode ser visto como um todo" como veria a relação entre ruas e praças através da fotografia panorâmica apresentada a seguir?

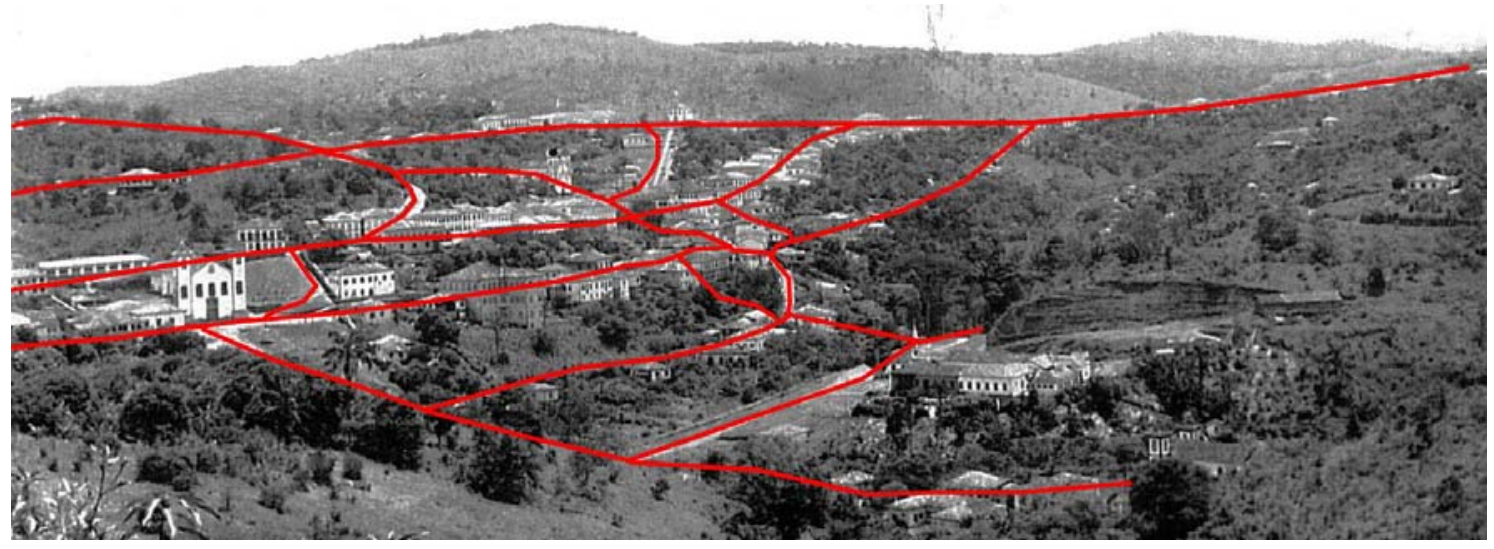

Figura 22. Vista panorâmica do Serro - início do século XX (sistema viário em linhas vermelhas)

Fonte: adaptado de LAFODOC -EA UFMG 
Para o autor vienense, os sistemas de traçados de ruas voltados para as especificidades orientadas exclusivamente para o tráfego trazem consigo êxitos irrisórios para "justificar a pouca consideração dada ao auxílio da arte, aos ensinamentos da história e a toda a grande tradição da construção urbana" (SITTE, 1992, p.107). Desta mesma maneira danosa, considera a presença da vegetação em espaços urbanos livres (praças, ruas, largos).

quanto mais os motivos paisagísticos se aproximam do centro de uma cidade grande, em especial das imponentes construções monumentais, tanto mais difícil é encontrar-se uma solução satisfatória em termos gerais e irrepreensível do ponto de vista artístico (SITTE, 1992, p.107).

Em sua justificativa quanto à negatividade da presença da vegetação em praças, o autor chama atenção para o comprometimento que as folhagens trazem às tomadas de perspectivas dos espaços das praças.

Após apresentar a disparidade do método antigo e moderno até mesmo por meio dos jardins, Sitte apresenta a seguinte síntese de recapitulação:

fechamento do espaço e dos efeitos de visão era a base de todas as disposições nas cidades antigas, e derivou da evolução histórica de uma rua que era sem interrupções quando de sua formação, como ainda hoje ocorre nas aldeias (SITTE, 1992, p.110).

Assim, o autor entende que muito do que havia nas cidades antigas, onde 0 homem estava habituado à beleza e ao aconchego, perdeu o encanto de maneira irrecuperável.

caso queiramos dar livre trânsito a esse triste fado [perda irrecuperável da qualidade da cidade antiga], mas pelo contrário, salvar ainda o que for possível do valor artístico das cidades, devemos ter bem claro o que ainda pode ser mantido e o que deve ser deixado de lado (SITTE, 1992, p.111). 
Entendemos que, para Sitte (1992), "o que deve ser mantido" representa o que deve ser preservado, conservado. E este trabalho de salvamento pode ser obtido por intervenções como a restauração. Nesse sentido, a ampliação do conhecimento dos estudos urbanos sittianos nos possibilita entender sua influência em pesquisadores da restauração e da intervenção urbana como Gustavo Giovannoni. De acordo com Jokilehto (1986), Giovannoni, influenciado por Camillo Sitte em seus estudos sobre restauração, enfatizou valores visuais e pitorescos da cidade, e as surpresas súbitas causadas pelo contraste entre palácios suntuosos, conventos, igrejas e a arquitetura "secundária" das pequenas casas. Desta maneira, a cada momento reforça-se a adequada utilização dos métodos de Camillo Sitte, para identificação da matéria em uma estrutura espacial urbana, visando a sua restauração.

De acordo com Sitte (1992), muitas das antigas formas de construção perderam seu sentido. A dinâmica social antiga era outra, ou seja, naquela época a vida era muito mais favorável à concepção artística da construção urbana que a vida moderna. O autor chama a atenção para o fato de que, nas cidades da modernidade, a população é grande ou é elitizada, o que gera uma valorização da propriedade urbana. Esse processo tem como conseqüência direta que "a abertura de ruas e o parcelamento do terreno ocorrem como processo espontâneo, de modo que mesmo nas regiões mais antigas da cidade surgem sempre novas vielas laterais" (SITTE, 1992, p.113). Esse fenômeno é considerado pelo autor como nefasto e irreversível em termos estéticos. 
Sitte considera que para a modernidade ficou economicamente difícil escapar do parcelamento do terreno. Entretanto, o autor se contrapõe a essa realidade.

não podemos render cegamente aos efeitos de um método utilizado com tamanha freqüência, e que sacrifica sem piedade as belezas da construção urbana. São todas essas belezas que designamos pela palavra pinturesco (SITTE, 1992, p.113-114, grifo nosso).

Curiosamente esta é a realidade de nossas cidades antigas (do Brasil), onde por diversos interesses econômicos e mercadológicos, o adensamento desfigura a estrutura urbana original. E, nesse caso, não se trata de questões sociais coletivas, mas de investimentos empresariais individuais. Sitte (1992) alerta que "os altos preços dos terrenos exigem seu melhor aproveitamento, e com isso os lotes construídos tomam forma cúbica do 'moderno bloco de construção' - abandonando inúmeras possibilidades formais".

Para Sitte (1992), na cidade antiga elementos da arquitetura dos prédios mais importantes possuem escadarias e pórtico, tão destacados que "a cidade inteira é embelezada e honrada pelo efeito artístico destes elementos, que a postura moderna considera pouco práticos" (compreendemos estes valores em Serro ver Figuras 141, 142, 142 e Figura 178). Para o autor, na utilização desses motivos arquitetônicos, que se deslocam da arquitetura interna para o espaço exterior (escadarias, galerias, etc), que consiste, de fato, o encanto das cidades antigas. Entendendo a valorização que tais elementos e detalhes construtivos trazem aos ambientes urbanos, Camillo Sitte (1992) apresenta motivos "pinturescos" na arquitetura antiga, tida por ele como encantadora e dinâmica, que possibilitam a compreensão específica de acordo com a percepção de cada um, dada a 
combinação peculiar de cada edifício, da mesma forma que se encontra em cenários teatrais (SITTE, 1992, p.115).

De acordo com o autor são motivos pinturescos desta arquitetura percebida como "cenários", projeções arquitetônicas mais vigorosas, interrupções na linha frontal dos edifícios, ruas tortuosas e angulosas, ruas de larguras variadas, diferentes alturas de edifícios, escadarias, loggias, cumeeiras, sacadas.

A partir de uma leitura da importância da preservação e de sua dificuldade, entende-se que "o traçado de um castelo antigo é bastante agradável para um rápido passeio no verão, mas para residir preferimos a construção moderna com toda a gama de conforto que nos oferece" (SITTE, 1992, p.116). Essa situação representa um dos maiores problemas atuais da preservação em centros históricos brasileiros, cuja população busca incessantemente tornar seu espaço de moradia adequado às suas expectativas, nem sempre favoráveis à preservação. Disso resulta que, segundo o autor, todas as coisas possuem sempre em sua natureza uma contradição interna entre o "prático" e o "pinturesco".

todavia, esta luta interna entre duas reivindicações oponentes não
caracteriza apenas a construção urbana, mas existe em todas as artes,
mesmo nas aparentemente mais livres, ao menos enquanto conflito entre as
suas metas ideais e as restrições causadas pelo material em que a obra de
arte assume a sua forma (SITTE, 1992, p.116).

Se a matéria colabora na definição da forma e restringe o prático do pinturesco, entendemos que tal abordagem do autor interessa no sentido de evidenciar a leitura de valoração e a importância que a matéria possui em sua natureza estética. O que aproxima, mais uma vez, Camillo Sitte do nosso objeto de 
estudo e objetivo principal quanto à verificação da possibilidade de um restauro urbano, uma vez que seguiremos Cesare Brandi em sua afirmação de que se restaura apenas a matéria da obra de arte.

Percebemos que os limites da atuação artística na construção urbana têm se mostrado muito restritos por que "falta-nos um ideal estético, carentes que somos de uma visão de mundo unânime e vívida na alma de um povoe que possa encontrar na obra de arte a sua expressão sensível" (SITTE, 1992, p.116-117).

O autor vienense acredita que não se pode alterar a realidade dos fatos da construção urbana da modernidade, tornando-se irrecuperável boa parte das belezas pinturescas estudadas, e chega ao resultado de que

as magníficas obras antigas, verdadeiros modelos legados pelos mestres do passado, devem permanecer vivas entre nós de outro modo que não através da imitação insensata; e apenas quando apreendermos sua essência e conseguirmos aplica-la com sensatez às circunstâncias modernas é que será possível obter ainda uma colheita florida de uma terra que se tornou estéril (SITTE, 1992, p.117, grifo nosso).

Será que podemos perceber nesta abordagem de Sitte a presença de princípios para uma restauração, quem sabe urbana? Para Camillo Sitte (1992), é necessário perceber que "a cidade é o espaço da arte por excelência, porque é esse tipo de obra que surte efeitos mais edificantes e duradouros sobre a grande massa da população".

No auxílio à resposta desta indagação, Sandro Ranellucci (2003) nos indica a importância de Sitte para o restauro urbano, quando afirma que ele propôs um novo modo de conceber a cidade e seu planejamento, que une a cidade antiga e a contemporânea, conciliando a exigência desta última com o modelo acumulado do 
ambiente urbano do período clássico. Para Ranellucci, Sitte teoriza que o valor do monumento consiste no legado que ele traz ao ambiente que o envolve. Mesmo fundamentado em uma leitura relativa ao espaço da cidade antiga, o pensamento de Camillo Sitte "definitivamente eleva-se para uma antecipação criadora do modo moderno de entender o campo disciplinar do restauro urbano" (RANELLUCCI, 2003, p.25, tradução da autora).

\subsection{A cidade como obra de arte}

A acepção tradicional e etimológica de arte deriva do latim "ars" e teria um âmbito consideravelmente mais amplo do que se tem hoje em dia. Compreendia não somente as belas artes, mas todos os ofícios manuais, e incluía todos os objetos feitos pelo homem em contraposição às obras da natureza. Como podemos observar, esse conceito se aproxima bastante do atual conceito de "bem cultural". Atualmente, o conceito de obra de arte está fortemente atrelado àquilo que é feito pelo homem, suscetível de ser contemplado esteticamente.

González-Varas (1999) entende que "as obras de arte se caracterizam por serm objetos feitos pelo homem que, de um modo absoluto, atuam esteticamente na 
experiência humana", e é esta especial "capacidade estética" que Ihe prenuncia características peculiares dentro do conjunto de "bens culturais" e distingue a obra de arte do resto dos objetos produzidos pelo ser humano. Entretanto, não podemos deixar de evidenciar que a obra de arte possui ainda um caráter testemunhal, ou seja, carrega uma bagagem histórica. Mas seus valores artísticos estão correlacionados à estética, e neste sentido cabe o apontamento de, pelo menos, análises fundamentais a partir de seus valores sensoriais, formais e expressivos.

De maneira simplificada, podemos dizer que a sensação em uma obra de arte ocorre a partir de uma relação fenomenológica em que o objeto em si provoca uma resposta estética resultante da satisfação obtida a partir da textura, da rugosidade, da luz, da cor, existentes em torno dela.

Já os "valores formais", entende-se que são uma síntese dos valores sensoriais, pois são o resultado da relação dos elementos sensitivos, ou seja, a obra de arte possui uma estrutura que surge da organização global resultante das interrelações dos elementos básicos de que consta. Portanto, cada obra de arte possui um modo único de organização e constituição, "uma unidade", que nas artes figurativas é tratada como "unidade de imagem". No caso de uma cidade, por exemplo, podemos perceber essa característica na disposição dos edifícios em uma trama urbana, na relação com a geografia, na interface entre o edificado e o não edificado. Ou seja, "a unidade é uma importante qualidade formal das obras de arte que determinará as opções de sua conservação e restauração" (GONZÁLEZVARAS, 1999). 
Portanto, ainda tomando por base González-Varas (1999), sobre os valores da obra de arte correlacionados à estética, que foram analisados como essenciais, cabe dizer, assim como os demais, que aqueles ditos "valores expressivos" são fundamentais, por serem entendidos como "vitais" ou "associativos", pois é através deles que o espectador intuitivamente transfere para a obra de arte emoções e sentimentos próprios. Dessa maneira, ao reunirmos tais valores "associativos" com os "formais", percebemos com maior facilidade as qualidades estéticas da obra de arte, que garantem sua fruição.

Para Andrade (1995), ao considerar a cidade enquanto obra de arte e manufatura, "a história urbana propõe descobrir a dimensão simbólica e representativa do espaço construído pelo homem", e através desta valorização arquitetônica do ambiente urbano, é que a referida história procura desvendar a cidade em seus aspectos plásticos, onde, segundo ele, a "dimensão plástica e formal da cidade, a arquitetura de seus tipos edilícios e a morfologia de seu traçado adquirem aí importância decisiva". É a partir da apreensão da essência da cidade que a intervenção em seu espaço se torna coerente.

Camillo Sitte é um dos maiores estudiosos do espaço urbano no que se refere à leitura formal e artística. Choay (2001) acredita ser ele o grande mentor da morfologia urbana. Sua importância é acentuada por Sandro Ranellucci (2003), que em sua obra, "Il restauro urbano: teoria e prassi", destaca que, a idéia moderna de restauração começou a se delinear na segunda metade do século XIX com 0 surgimento da distinção entre "cidade histórica" e "cidade contemporânea"; e se fez 
devido a importantes contribuições de Camillo Sitte e, no que se refere ao restauro propriamente dito, de Alois Riegl e Gustavo Giovannoni.

Para Schorske (1988), em Camilo Sitte a cidade deve ser "uma obra de arte espiritual significativa..., um elemento de arte popular grandioso e autêntico...", não havendo dúvidas quanto à natureza artística da cidade. Por meio da percepção da artisticidade urbana, acreditamos que, na cidade enquanto obra de arte, a fruição artística está correlacionada à estética. Conforme aponta Carbonara (2005), referindo-se a Brandi, que retém em suas formulações a presença do idealismo e do espiritualismo de Benedetto Croce, esta valoração é presente nos preceitos restaurativos da Teoria Del Restauro, onde a razão do conhecimento humano, relativo ao processo mental de percepção, considera o sentido e a inteligibilidade de um objeto, dependentes do sujeito que o compreende.

Para ilustrar a influência de Benedetto Croce em Brandi, na busca pela compreensão do que para ele é obra de arte a ser restaurada, recorremos a Jokilehto (1986), que nos permite observar que Benedetto Croce se organizou dentro da moderna filosofia de estética, com seu pensamento baseado em Hegel, na filosofia romântica clássica. Tendo criado um método de avaliação estética, independente e prático, enfatizando a qualidade do todo de um objeto em cima das qualidades de seus detalhes, Benedetto Croce percebeu um dos problemas principais da estética na restauração, vendo a essência da pura arte contra as emoções, indicando importantes caminhos adotados pelo processo restaurativo do pós-guerra. 
Croce formou a base conceitual para a teoria de restauração que surgiu após a Segunda Guerra Mundial. De Benedetto Croce se fundamentou o denominado "restauro critico", como especialmente expressado dentro da Itália por Argan, Pane, Bonelli e Brandi que teve importante influência na formulação dos princípios da Carta Internacional de Restauração de 1964 - a Carta de Veneza. (JOKILEHTO, 1986, p.412-413 - tradução da autora).

Em Cesare Brandi (2005) esta leitura do todo sobre os detalhes é demonstrada com clareza em seus preceitos de restauro. Acreditamos que ao entender os apontamentos de Croce quanto à compreensão atribuída ao objeto como um "todo" e suas bases estéticas, ampliaremos a capacidade de percepção da importância do legado de Argan, quanto à leitura da cidade enquanto obra de arte, assim como a possibilidade de aplicação da Teoria brandiana ao espaço urbano, uma vez que, para Brandi (2005), a restauração incide sobre a matéria da obra de arte com vista à sua transmissão para o futuro. Acreditamos que, por meio da compreensão de estudos de Benedetto Croce, obteremos uma maior elucidação da importância da estética nos princípios de restauração elaborados por Cesare Brandi.

Para Croce (1990) "arte é aquilo que todos sabem o que é" e possui um significado circunstanciado sendo passível de ser referido às dificuldades específicas que surgem num momento específico da história do pensamento.

\footnotetext{
arte é visão ou intuição. O artista produz uma imagem ou fantasma; e quem aprecia $a$ arte dirige $o$ olhar para o ponto que 0 artista lhe apontou, olha pela fresta que the abriu e reproduz em si aquela imagem. 'Intuição', 'visão', 'contemplação', 'imaginação', 'fantasia', 'figuração', 'representação', e assim por diante, são palavras que recorrem continuamente, quase sinônimos no discorrer acerca da arte, e que todas elevam nossa mente ao mesmo conceito ou à mesma esfera de conceitos, indício de um consenso universal (CROCE, 1990 p.35-36).
}

O autor aponta uma negação implícita na definição da arte como intuição esclarecendo que, se "intuição vale por teoria" no sentido de contemplação, a arte não pode ser "um ato utilitário", e segundo ele "um ato utilitário visa sempre a 
alcançar um prazer e, portanto, afastar uma dor; a arte considerada em sua própria natureza não tem nada a ver com o útil, nem com o prazer, nem com a dor enquanto tais". Croce (1990) entende que a arte pode trazer sensações de prazer independentemente de seu reconhecimento como tal. Para ele, arte é uma forma particular de prazer.

seu caráter distintivo seria dado não pelo agradável, mas por aquilo que distingue aquele agradável dos outros agradáveis, e é parar esse elemento distintivo - mais que agradável ou distinto do agradável - que conviria dirigir a investigação (Croce 1990, p.38).

Assim, Croce (1990) lembra que a doutrina que define a arte como sendo agradável é a própria estética hedonista e esclarece que não está negando a doutrina hedonista - que evidencia o prazer que é compartilhado pela atividade estética e por todas as formas de atividade espiritual - quando nega a identificação da arte como agradável, e quando distingue a arte do agradável, ao defini-la como intuição. O autor lembra ainda que

a arte não nasce por obra da vontade: a boa vontade, que define o homem de bem [onest' uomo], não define o artista.

$[\ldots]$

uma imagem artística representará um ato moralmente louvável ou reprovável; mas a imagem, enquanto a imagem, não é nem louvável ou reprovável moralmente (CROCE, 1990, p.39).

Para Croce (1990), deriva da "doutrina moralista" o objetivo preestabelecido de que a arte deva orientar para o bem, fornecer estímulos de aversão pelo mal, procurar melhorar os costumes, onde o pedido aos artistas é que contribuam, no que Ihes cabe "para a educação civil das plebes, para o fortalecimento do espírito nacionalista ou guerreiro de uma população, para a difusão dos ideais de vida modesta e laboriosa, e assim por diante" Croce (1990 p.40). O autor lembra que as 
artes não têm esta capacidade e, por isso, não perdem a respeitabilidade. Para ele a arte foi, muitas vezes, apropriada como instrumento didático, conduzindo os homens "por um jardim de Armida".

Dentre os apontamentos de Benedetto Croce (1990) há ainda o destaque para outra questão de relevância: ele define a arte como intuição, negando "que ela tenha um caráter de conhecimento conceitual", pois o conhecimento conceitual é sempre realista e

\begin{abstract}
a intuição significa, precisamente, indistinção de realidade e irrealidade, a imagem em seu valor de mera imagem, a idealidade pura da imagem; e ao contrapor o conhecimento intuitivo ou sensível ao conhecimento conceitual ou intelegível, a estética à noética, visa-se a reivindicar a autonomia desta forma de conhecimento, mais simples e elementar, que foi comparada ao sonho (não ao sono) da vida teorética, relativamente ao qual a filosofia seria a vigília (CROCE, 1990, p.41).
\end{abstract}

Para o autor, o conceito de arte como intuição exclui, ainda, "a concepção de arte como produção de classes e tipos e espécies e gêneros" ou mesmo como exercício de aritmética inconsciente; ou seja "distingue a arte das ciências positivas e das matemáticas", entendendo que, em ambas, está presente a forma conceitual, embora privada - de caráter realístico, como mera representação geral, ou mera abstração.

O filósofo afirma que a "arte não é pura intuição" uma vez que representa a produção de uma imagem, e não de uma acumulação incoerente de imagens, que
se obteria evocando imagens antigas, deixando que se sigam umas às outras por
um ato de arbítrio, combinando uma imagem com outra por outro arbítrio
semelhante, juntando a cabeça humana com uma cerviz eqüina, numa brincadeira
de criança (CROCE, 1990, p.46). Nesse sentido, precisa-se "aprofundar mais o caráter da fantasia e da mera intuição". E, para preparar esse aprofundamento, o melhor é 
recordar e criticar as teorias em que se tentou diferenciar a intuição artística da mera imaginação incoerente, e estabelecer em que consiste o princípio da unidade, e justificar o caráter produtivo da fantasia. A imagem artística é tal quando une a um sensível um intelegível e representa uma idéia (CROCE, 1990, p.47).

Inteligível e idéia, para Croce (1990), exprimem conceito, mesmo que seja conceito concreto ou idéia, próprio da alta especulação filosófica - distinto do conceito abstrato e do conceito representacional das ciências. O autor enfatiza que:

\begin{abstract}
em qualquer dos conceitos, o conceito ou a idéia une o intelegível ao sensível sempre e não somente na arte, porque o novo conceito de conceito, inaugurado por Kant e, por assim dizer imanente em todo o pensamento moderno, veio sanar a cisão entre o mundo sensível e mundo intelegível, concebendo o conceito como juízo, o juízo como síntese à priori, e a síntese como o verbo que se fez carne, como história (CROCE, 1990, p.47).
\end{abstract}

Para melhor entendimento do que é arte, Croce (1990) discute os preconceitos que a envolvem, indicando inicialmente os prejuízos oriundos do século XIX quanto à divisão dos estudos da estética do conteúdo (Gehaltsaesthetik) e da estética da forma (Formaesthetik), no questionamento sobre em qual ou quais delas a arte se encerraria. Disto resulta o interesse do autor pela "dialética na qual os conteudistas involuntariamente se tornaram formalistas e os formalistas se tornaram conteudistas". Dessa desinquietação despertaram as "formas belas" que não diferem dos "conteúdos belos". Entretanto, Croce (1990) alerta de que conteúdo e forma devem estar bem distintos na arte, mas não podem qualificar-se separadamente como artísticos. Acreditamos que tal entendimento possa se aproximar da fundamentação daquele apresentado por Brandi (2005) como aspecto e estrutura da obra de arte.

porque só é artística sua relação, isto é, sua unidade, entendida não como unidade abstrata e morta, mas como aquela unidade concreta e viva que é própria da síntese a priori; e a arte é uma verdadeira síntese a priori estética, de sentimento e imagem na intuição (CROCE, 1990, p.56). 
O filósofo chama a atenção para a percepção de que da mesma maneira, não se "separa a intuição da expressão, a imagem da tradução física", não havendo interior e exterior da arte. Insistindo nesta busca pela distinção entre arte e aquilo com que se costuma confundi-la, ele evidencia ações que equivocadamente se aderiram aos conceitos de expressão estética, separando-os "da expressão estritamente considerada, (...) , e da beleza da expressão, ou ornato" (CROCE, 1990), que é o fundamento das expressões "nuas" e "ornadas" diante de uma obra de arte. Nesse sentido, ele lembra que beleza e expressão representam um só conceito.

Para Croce (1990), há várias ou muitas formas particulares de arte, cada uma delas determinável em seu próprio conceito e limites, e dotada de leis próprias. O filósofo se firma na reflexão de que é "infundada qualquer teoria da divisão das artes", uma vez que a produção da arte é espontânea e seu juízo é filosófico. Não se devem confundir índices de estudos, de categorização da arte com a realidade dela. Para o autor de Breviário de Estética, "na história, cada obra de arte toma o lugar que Ihe cabe" (1990), e afirma ainda que a ligação entre a filosofia e a estética é intrínseca e não extrínseca. Na filosofia moderna, segundo Croce (1990, p.113) "o pensamento crítico é que é o principal, e a metafísica, o episódico", da mesma maneira ele acredita que Kant define obra de arte como "representação adequada de um conceito, na qual o gênio combinaria intelecto e imaginação". O autor entende que um "problema de estética" trata de um problema lógico ou ético. Entendemos que para Cesare Brandi não é diferente, uma vez que para ele 
o produto especial da atividade humana a que se dá o nome de obra de arte, assim o é pelo fato de um singular reconhecimento que vem à consciência:[...] até que o reconhecimento que a consciência faz dele [o produto humano] como obra de arte, o excetue, definitivamente, do comum dos outros produtos (BRANDI, 2005, p.27).

Acreditamos que o reconhecimento realizado pela consciência da obra de arte enquanto cidade tem, no século XX, Aldo Rossi como um dos importantes estudiosos. Neste sentido recorremos a ele, que acredita ser a obra de arte coletiva o especial produto humano, e que a cidade constituída por arquitetura representa a chave da leitura e interpretação dos fatos urbanos. A cidade é compreendida por Rossi (2001) como uma grande representação da condição humana lida através da sua cena fixa e profunda; a arquitetura como

coisa humana que forma a realidade e conforma a matéria segundo uma concepção estética. $\mathrm{E}$, assim, ela mesma não é só o lugar da condição humana, como até uma própria parte desta condição, que se representa na cidade e nos seus monumentos, nos bairros, nas residências, em todos os fatos urbanos que emergem do espaço habitado (ROSSI, 2001, p.50).

O autor vislumbra a cidade como algo que foi produzido como obra de arquitetura, ou de engenharia, que se amplia no tempo. Para ele, edifícios são como monumentos que fazem parte de um todo - a cidade.

Entretanto, Argan (1998, p.216) entende que as teorias urbanísticas mais recentes desenvolveram-se num sentido ecológico, em que passa a denominar "ambiente urbano" o objeto de estudo da cidade e não mais o "espaço urbano", que se referia ao projetável. Agora se entende que o ambiente é condicionado, mas não estruturado ou projetado.

a cidade é feita de coisas, mas essas coisas nós as vemos, oferecem-se como imagens à nossa percepção, e uma coisa é viver na dimensão livre e mutável das imagens, outra é viver na dimensão estreita, imutável, opressiva, cheia de arestas, das coisas (ARGAN, 1998, p.220). 
O autor reivindica que a cidade moderna realize esta passagem da concretização da "dureza das coisas" à mutabilidade das imagens. Nesta interpretação da imagem, deve ser contemplada não apenas "a coisa" mas a "imagem dada como coisa". Para Argan (1998), o urbanismo e a arquitetura foram submetidos a um lucro imediato de aparato industrial devido ao enquadramento "para um papel subsidiário de arte aplicada justamente pelos intelectuais-artistas". Nesse sentido, ele lembra que a cidade "não é a dimensão de uma função, é a dimensão da existência".

\footnotetext{
hoje, não podemos mais conceber a distinção entre um espaço interno e um espaço externo, entre um espaço apenas meu e um espaço de todos. Hoje, é componente do espaço urbanístico qualquer coisa que, na contínua mutação da realidade ambiental, retém por um instante nossa atenção (ARGAN, 1998, p. 224).
}

Para o autor, essa realidade nos obriga a reconhecermo-nos em objetos ou em algo que não conhecemos, cuja interpretação ainda devemos encontrar. Argan (1998) entende que todas as pesquisas visuais deveriam ser organizadas como pesquisas urbanísticas. Para ele, fazem urbanismo o escultor, o pintor; "faz urbanismo quem quer que realize alguma coisa que, colocando-se como valor, entre, ainda que nas escalas dimensionais mínimas, no sistema dos valores". O autor afirma que a obra de arte não é mais mercadoria, e que o urbanismo não deveria se ater ao ensino superior e restrito à arquitetura, mas se ampliar a todos os indivíduos no sentido de que seja criada a educação para a construção da cidade como "forma sensível da civilização", como unidade urbana, organismo histórico em desenvolvimento, com "o fim a que deveria visar uma arte que fosse consciente de ser e dever ser, como sempre foi, um fato de cultura urbana, e cuja teoria, mais ainda do que uma estética seria um urbanismo geral" (ARGAN, 1998). 
E, indagando o que é urbanismo, se arte ou ciência, sociologia, economia, política, tecnologia, Argan (1998) entende que "urbanismo é, em substância, programação e projeto", onde projeto está fundamentado em "dados estéticos, sociológicos, econômicos, políticos, tecnológicos", não se limitando à combinação destes dados, e indica o plano diretor como sendo o "projeto de desenvolvimento do urbanismo". Para ele, projetar é "conservar e transmitir", e questiona então o que conserva o urbanismo que projeta o desenvolvimento das cidades. Percebe-se, então, tratar dos valores ditos "histórico-estéticos", apresentados como "um único" e não distintos. Exemplifica, por meio do significado urbanístico do Coliseu e da sua alteração física em relação à concepção original. Argan (1998) enfatiza que, mesmo com as perdas de reconhecimento estético, o Coliseu mantém indiscutível valoração atribuída por todas as entidades romanas, sejam elas técnicas, políticas, empresariais, comunitárias. Percebe-se que o Coliseu se faz presente em vasto raio urbano e é das mais importantes representações simbólicas de Roma.

A partir desse entendimento, Argan (1998) chama a atenção para a percepção de que o "problema é justamente o do valor estético da cidade, da cidade como espaço visual". O autor não se atém ao fato de que a cidade possa ser considerada uma obra de arte ou um conjunto de obras de arte. E, por isso, entendemos que o exemplo apresentado pelo Coliseu é elucidativo, pois

são os homens que atribuem um valor às pedras e todos os homens, não apenas os arqueólogos ou os literatos. Devemos, portanto, levar em conta, não o valor em si, mas a atribuição de valor, não importa quem faça e a que título seja feita. De fato, o valor de uma cidade é o que lhe é atribuído por toda a comunidade e se, em alguns casos, este é atribuído apenas por uma elite de estudiosos, é claro que estes agem no interesse de toda a comunidade, porquanto sabem que o que é hoje ciência de poucos, será amanhã cultura de todos (ARGAN, 1998, p.228). 
É preciso, portanto, observar em todos os níveis culturais a atribuição de valor aos dados visuais da cidade. A experimentação dos espaços, da arquitetura é freqüente e distinta. Portanto, Argan (1998) chama atenção para que não se identifique a função de um edifício inserido no contexto urbano, uma vez que "a função não outorga o significado, mas simplesmente a razão de ser". Para esclarecer esse entendimento, o autor utiliza o exemplo de uma estação de trem, que pode representar o ponto de partida de um trem, ou ponto de fixação visual no contexto urbano (uma referência), podendo ter seu significado relacionado ao ambiente urbano, permitindo ao indivíduo se localizar aí.

O significado da interpretação coletiva dos valores urbanos é gerenciado pelo urbanismo, e a configuração mental do espaço urbano de um indivíduo representa um emaranhado de sinais marcados por "ritmos repetidos, certos traçados, certos pontos de convergência que corresponderiam com certeza a atribuições de valor". Composto por várias camadas que se inter-relacionam, conservando sempre os valores já existentes, lembrando que a "cidade não se funda, se forma", por meio de um processo, pelo qual nos deparamos com uma cidade que deixa de ser lugar de abrigo e torna-se instrumento de comunicação, contemplando a transmissão de conteúdos urbanos (ARGAN, 1998).

Através dos estudos de compreensão da significação da cidade, Argan (1998) enfatiza a analogia que traça entre "o fenômeno da formação, da agregação e estruturação do espaço urbano e o da formação, agregação e estruturação da linguagem". Isso aproxima o lingüista do urbanista. 
a configuração humana, enfim, não seria mais do que o equivalente visual da língua, e não tenho nenhuma dificuldade em admitir que os fatos arquitetônicos estão para o sistema urbano assim como a palavra está para a língua (ARGAN, 1998, p.237).

O autor apresenta, então, que a função urbana se compara a um discurso, e aquilo que entendemos como espaço visual, senso espacial da cidade, é construído a partir das relações associativas, e constitui o pensamento da cidade. E é essa realidade que possibilita ao indivíduo se identificar como citadino, da mesma maneira que na língua pode-se identificar a natureza do ser humano e de qual país ele vem. Através dessa analogia, Argan (1998) entende ainda que a função no contexto urbano "constitui o acento axiológico", a expressão de intencionalidade.

A cidade conhecida como espontânea "era determinada pela evidência que a figura histórica da cidade tinha na consciência individual e coletiva" (ARGAN, 1998). Disso resulta que o verdadeiro objetivo do especialista dos valores culturais da cidade está em ser educador e não a técnico, pois seu real objetivo não deve ser "criar a cidade, mas formar um conjunto de pessoas que tenham o sentimento da cidade", de maneira que cada qual possa "reconhecer a si mesmo e à sua experiência da vida associada" (ARGAN, 1998, p.241). Para o historiador da arte a atribuição do valor artístico ao ambiente urbano depende de um juízo acerca da historicidade desses ambientes, e podem ser consideradas as "tendências atuais da historiografia artística com adoção de metodologias sociológicas ou antropológicas".

Estudiosos apontam constantemente a importância da cidade enquanto arte, indicando os processos mentais característicos da arte, presente nas técnicas urbanas atuais. Ao se referir às questões da modernidade, Argan (1995, p.36) afirma que 
a cidade como residência de uma comunidade desapareceu; e visto que, em toda a sua história, a arte é o produto de técnicas urbanas para a construção do ambiente da vida social, o da cidade, não surpreende que ao fim da cidade se siga o fim da arte.

Acreditamos estar compreendida a natureza artística da cidade, e consideramos interessante destacar que se torna importante resgatar o entendimento de Argan (2005) de que a cidade é uma entidade histórica absolutamente unitária, e uma das grandes tarefas culturais dos arquitetos é resgatar as periferias urbanas de uma condição de inferioridade ou até mesmo de semicidadania, pois "a obra de arte é o objeto único que tem o máximo de qualidade e o mínimo de quantidade". 


\section{Capítulo 2 - A cidade-patrimônio}

Neste capítulo, apresentamos o objeto de estudo de nossa pesquisa, a cidade patrimônio cultural Serro, através de sua trajetória existencial. Discutimos seu valor estético, com o auxílio dos subsídios que obtivemos no capítulo anterior, sua origem histórica e principais transformações urbanísticas. Buscamos investigar sua realidade de preservação, pretendendo discutir a condição atual de sua forma urbana, utilizando para tanto as análises obtidas a partir dos princípios de Camillo Sitte (1992) aplicados ao universo urbano setecentista de Serro.

\subsection{Atribuição do valor estético}

Procuraremos evidenciar aqui a natureza artística da cidade. Acreditamos que este reconhecimento parta da percepção de cada um, conforme princípios da fenomenologia indicados por Cesare e Brandi (2005), e da compreensão das relações de valores esclarecidas por Argan, conforme capítulo anterior. Entretanto, no caso do Serro, esta tomada de consciência ocorreu primeiramente de maneira 
técnica por intelectuais modernistas brasileiros em 1938, e isso nos apresenta uma condição especial para nossas análises.

\begin{abstract}
A obra de arte (pintura, escultura, expressão arquitetônica, mas também centro histórico ou paisagem), como tal e como produto ou testemunho da atuação humana em um certo tempo e lugar, coloca a dúplice instância fundamental segundo a qual se deve estruturar: a histórica e a estética, podendo cada qual, para fins da restauração, ter exigências próprias, diversas e contrastantes, desde a pura conservação, por um lado, até as propostas profundamente reintegrativas, por outro (CARBONARA , 2003, p.11, tradução da autora).
\end{abstract}

Carbonara (2003) não apresenta dúvidas quanto à condição de obra de arte do "centro histórico ou paisagem" e, como "produto ou testemunho da atuação humana", deve ser estruturado a partir da instância estética e histórica, que podem impor condições conflitantes. Esse entendimento pode decorrer da percepção de que

o produto especial da atividade humana a que se dá o nome de obra de arte, assim o é pelo fato de um singular reconhecimento que vem a consciência: reconhecimento duplamente singular, seja pelo fato de dever ser efetuado toda vez por um indivíduo singular, seja por não poder ser motivado de outra forma a não ser pelo reconhecimento que o indivíduo singular faz dele (BRANDI, 2005, p.27).

Para Beatriz Kuhl (2006), ${ }^{3}$ o que se refere no texto de Cesare Brandi como obra de arte deve ser compreendido por meio do alargamento deste conceito para o de bem cultural, conforme abrangência esclarecida também por Giovanni Carbonara (2006)

No Brasil, desde a década de 1930, com o Decreto Lei 25 e a criação do IPHAN, entendemos que o reconhecimento da artisticidade em obras de especial caracterização se tornou efetivamente sólido e oficial. O tombamento é um dos

\footnotetext{
3 Informação fornecida por Kühl em Seminário na FAU/USP, em 01 setembro de 2006, nas atividades
} comemorativas do centenário de nascimento de Cesare Brandi. 
principais instrumentos de preservação adotados, o mais antigo do Brasil, instituído justamente pelo referido Decreto, onde para Castro (1991) "o valor contido nas coisas de interesse cultural forma, no seu todo, o 'patrimônio histórico e artístico nacional', que é uma universalidade que, como bem jurídico, interessa a toda a coletividade, à sociedade nacional". Para ela se, através do Decreto Lei 25, o patrimônio cultural nacional reconhecido pela sua preservação é bem de interesse da coletividade, "pode inferir que esta comunidade de cidadãos passa a ter o direito público subjetivo de tê-lo protegido" (CASTRO, 1991). E isto, como refere Argan (1998), traz como importante ação o reconhecimento desses valores para a conscientização do indivíduo inserido na realidade atual, uma vez que a sua condição especial na memória da coletividade destes espaços, adquirida em tempos anteriores, se perdeu por meio dos interesses mercadológicos - podemos incluir nestes casos o turismo em massa, dentre outros - presentes de maneira expressiva na sociedade moderna. Acreditamos que os entendimentos de Sitte (1992) estão de acordo com estes apresentados por Argan (1995).

Consta, no Decreto Lei 25 de 1937, que:

\footnotetext{
Art. $1^{0}$ - constitui o patrimônio histórico e artístico nacional o conjunto de bens móveis ou imóveis, existentes no país e cuja conservação seja de interesse público, quer por sua vinculação a fatos memoráveis da história do Brasil, quer por seu excepcional valor arqueológico ou etnográfico, bibliográfico ou artístico.

$\S 1^{\circ}(\ldots)$

$\S 2^{\circ}$ - Equiparam-se aos bens a que se refere o presente artigo e são também sujeitos a tombamento os monumentos naturais, bem como os sítios e paisagens que importe conservar e proteger pela feição notável com que tenham sido dotados pela natureza ou agenciados pela industria humana". (BRASIL, 1937) [grifo nosso].
}

Percebemos que o Decreto Lei 25 de 1937 estipula como sendo de interesse público a ser protegido o "patrimônio histórico e artístico", caracterizando a 
universalidade da ação pretendida que se estende aos "monumentos naturais, sítios e paisagens", independentemente de sserem agenciados pela natureza ou pelo homem, indicando a amplitude do que pode ser entendido atualmente como bem cultural.

Ao se referir à tutela dos "bens móveis e imóveis", a lei se restringe àquilo que existe materialmente não estando, portanto, contemplado o "patrimônio imaterial". O Decreto Lei 25 refere-se apenas aos bens materiais, que possuem sua natureza classificada nos artigos 43 e 47 do Código Civil. Quanto a essa natureza, Castro (1991) evidencia aspectos importantes para a referência de tombamento de conjunto, como no caso de uma cidade.

evidentemente que, tanto no caso de tombamento de conjunto de bens móveis como no de imóveis, as coisas em si não perdem sua característica individual para efeitos civis, mas, para efeitos de tombamento, tornam-se uma só - o bem tombado (CASTRO, 1991, p.70) [grifo nosso].

Portanto, no tombamento do acervo arquitetônico e paisagístico da cidade de Serro, o que está tombado pelo ato administrativo não é cada imóvel individualmente, mas o todo (os efeitos do tombamento incidem sobre todas as partes deste todo). Por isso, de acordo com Castro (1991), o $\S 1^{\circ}$ do artigo $1^{\circ}$ do Decreto Lei 25 “refere-se à inscrição separada ou agrupadamente dos bens no Livro do Tombo, isto porque o valor susceptível de interesse público é o conjunto e não cada coisa individualmente". A jurista esclarece que o valor é sustentado pela materialidade da coisa, e que o objeto jurídico do tombamento não é a individualidade, mas o significado da representação dada pelo conjunto. 
o tombamento de conjunto de bens de valor cultural, móveis ou imóveis, forma uma universalidade de direito que por sua vez compõe a universalidade maior, que é o próprio 'patrimônio histórico e artístico nacional' (CASTRO, 1991, p.70).

O valor cultural da cidade contempla todos os imóveis inseridos no espaço ao qual pertence "o todo", que é reconhecido como "patrimônio histórico e artístico", e no caso de tombamento de cidade, para Castro (1991, grifo nosso) "estarão sob a tutela do poder público os prédios, ruas, a vegetação que adere o solo, os adereços fixados nos prédios, enfim, a paisagem urbana constituída de imóveis" (Figura 23 e Figura 24), pois representam a cidade, ou seja, o significado que todo o referido conjunto traz. Serro foi tombado pelo IPHAN em 08/04/1938, inscrição $n^{\circ} 25$, folha $n^{\circ}$ 06 do Livro do Tombo de Belas Artes, volume 01, como "Conjunto Arquitetônico e Paisagístico".

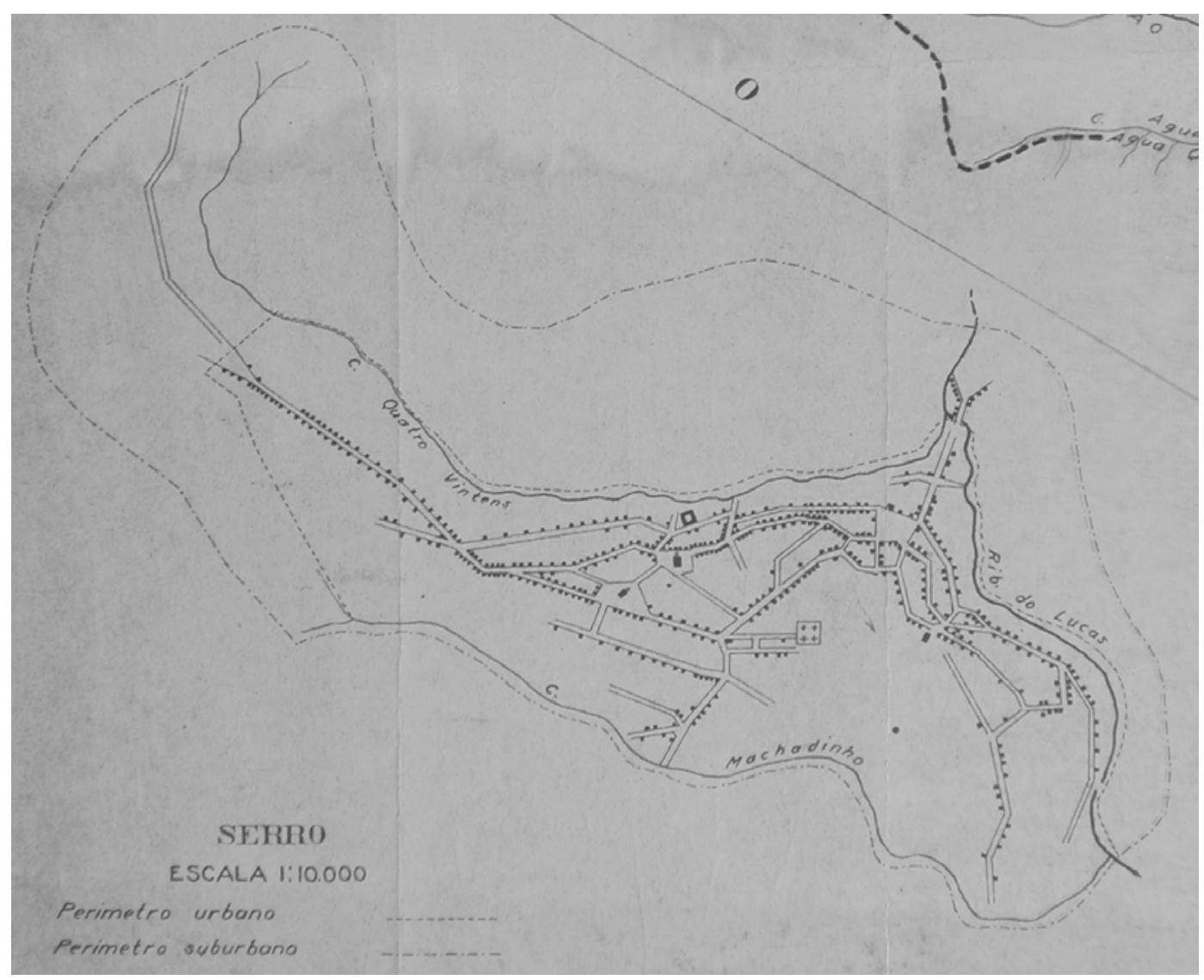

Figura 23. Planta cadastral esquemática da cidade de Serro em 1938 Fonte: Arquivo Público Mineiro 


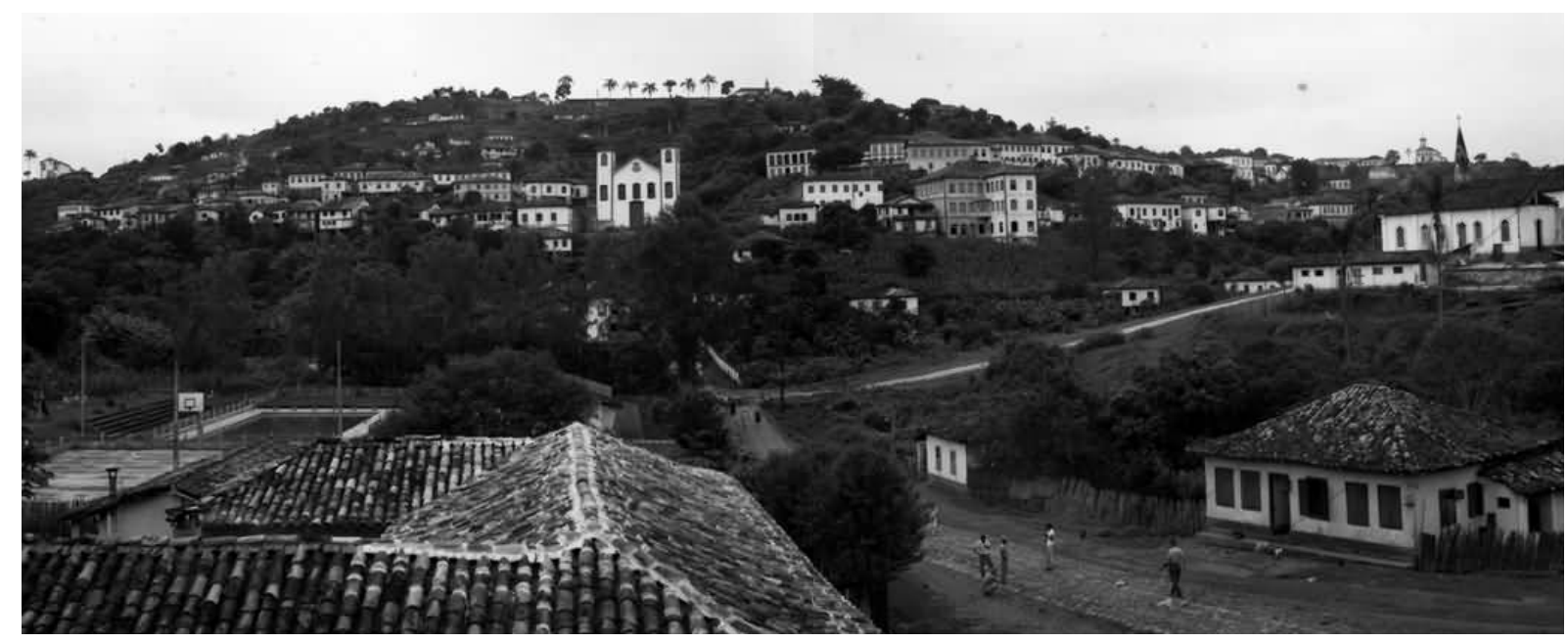

Figura 24. A cidade de Serro ainda na primeira metade do século XX. (LAFODOC - EA UFMG) Fonte: LAFODOC - EA UFMG (2006)

De acordo com o Decreto Lei 25 de novembro de 1937, são inscritas no Livro do Tombo de Belas Artes "as coisas de arte erudita nacional ou estrangeira". Entende-se, portanto, que o valor atribuído à cidade de Serro é de arte erudita, de acordo com Pougy (2005)

(...) a divisão de classes se refletiu nas artes. Assim, aconteceu mais uma separação, uma divisão entre arte erudita e arte popular. Os objetos de arte popular utilizavam recursos mecânicos e os objetos de arte erudita utilizavam recursos tecnológicos e eram complexos e sofisticados. Além disso, os objetos de arte erudita passaram a ter duas formas: uma forma expressiva e livre e uma forma funcional (POUGY, 2005, p.3).

Acreditamos que por estar inscrito no livro do Tombo de Belas Artes, que recebe as artes eruditas, o "conjunto arquitetônico e paisagístico" do Serro possa estar nessa compreensão de Pougy (2005). Tais atribuições quando da inscrição no livro do Tombo de Belas Artes das cidades é entendida por Lia Motta (1987), como desdobramento de reflexões intelectuais de membros do movimento modernista brasileiro, que, através de uma "revisão de conceitos de cultura e tomada de posição 
frente aos problemas culturais do país", incorporou-se de maneira minuciosa "na atuação do Patrimônio [IPHAN] sobre os centros históricos, determinando conceitos e critérios de preservação".

Entretanto, para a arquiteta, a relação entre tais idéias e a prática não ficou bem explicitada ao longo do tempo de ação da instituição. Segundo ela, o instituto de preservação nacional se envolveu em uma ação de "emergência, de salvaguarda e de alguns valores culturais, e posteriormente atônita diante de uma rotina consolidada de métodos inquestionáveis, só recentemente iniciou trabalhos de autoreflexão e crítica" (MOTTA, 1987, p.108).

É interessante percebermos que Lia Motta por meio deste artigo, busca um entendimento crítico da trajetória de atuação da instituição da qual faz parte, contudo nos convoca para refletir sobre a fundamentação da atribuição dos valores elencados pelo Decreto Lei 25 de 1937 e de responsabilidade de implementação do IPHAN. Retomamos os esclarecimentos de Castro (1991), quanto à inscrição automática dos bens enquanto "histórico e artístico" como condição para o tombamento de patrimônio nacional, a sua materialidade e unidade de todo, enquanto conjunto. Estes preceitos são a base do entendimento para uma adequada ação de preservação de bens com tais reconhecimentos.

\footnotetext{
as primeiras ações do Patrimônio [IPHAN] nos centros tombados tratavam a cidade como expressão estética, entendida segundo critérios estilísticos, de valores que não levavam em consideração sua característica documental, sua trajetória e seus diversos componentes com expressão cultural e parte de um todo construído (MOTTA, 1987, p.108).
}

Percebemos um indicativo de divergência conceitual e técnica quanto à ordem de reconhecimento da natureza, na qual se encontra determinado bem tido 
como "patrimônio histórico e artístico nacional". De fato, os quatro livros do Tombo em que se possa inscrever determinada "coisa" (assim denomina-se por ser material), contemplam a condição de arte a que o bem inscrito deve ter, sem, no entanto, excluir o caráter arqueológico, etnográfico, histórico que, determinadas "coisas" possam ter. Nesse sentido, encontramos em Shuwartzman (2000) citação de correspondência de Mário de Andrade a Carlos Drummond, quando afirma que

pouco depois de empossado em 1934, Capanema lhe havia solicitado que
elaborasse um projeto de lei de proteção às artes no Brasil, que seria o embrião do
Serviço do Patrimônio Histórico e Art́́stico Nacional. Desde São Paulo, Mário de
Andrade redige um texto que seria enviado para a aprovação do Congresso, e
terminaria sendo aprovado como decreto-lei em dezembro de 1937
(SHUWARTZMAN, 2000, p.61, grifo nosso).

Entendemos, então, que a primeira proposta de preservação no Brasil, exposta no do Decreto Lei 25 de 1937, de fato, em sua origem, é para tratar "do patrimônio artístico" - obra de arte. Desta maneira, é preciso que se entenda a amplitude do que atualmente se refere como "bem cultural", buscando compreender, conforme esclarece Carbonara (2006), quando deixa claro o quanto é atual a Teoria brandiana para a restauração da obra de arte, a partir do alargamento do que significa atualmente bem cultural. Acreditamos que, no caso do "patrimônio histórico e artístico nacional" brasileiro, esta ampliação deva ser mais bem sedimentada a partir do próprio instituto de preservação, mesmo considerando os amplos avanços neste sentido, ocorridos nos últimos anos, pois isso não se mostra amplo em toda a instituição. Consideramos a necessidade de maior compreensão do que é artístico, a que se refere, o termo "as coisas" definido pelo Decreto Lei 25 , em relação ao patrimônio cultural brasileiro. E, temos convicção de que essa distinção de 
determinada artisticidade acontece por meio de "um singular reconhecimento que vem à consciência", conforme afirma Cesare Brandi em sua Teoria Del Restauro.

Acreditamos, conforme Campello (1999), que "as cidades vivem um processo de acumulação em permanente evolução" e para que elas cresçam e evolua adequadamente é necessário "estabelecer a continuidade entre os seus valores antigos e novos em formação". O arquiteto se refere à cidade patrimônio cultural, àquela tombada pelo IPHAN, indicando-nos com clareza o alargamento do conceito de obra de arte/ patrimônio cultural, quando da atribuição dos valores a que a cidade está sujeita em sua materialidade.

Mesmo considerando a ampliação dos conceitos que envolvem a preservação, no caso brasileiro, percebemos que sempre houve uma busca neste sentido, ainda que pontual ou, mesmo pessoal, ocorrendo uma falta de unidade, que acabou gerando entendimentos e ações diversas como esclarece Motta (1987).

Costa $^{4}$ (1958, apud PESSOA, 1999), ao se referir ao conjunto arquitetônico e urbanístico de Ouro Preto, em um parecer técnico pelo IPHAN, afirma que "deveriam ser atacadas obras de maior vulto relacionadas com a restauração da cidade propriamente dita", orientando intervenções, em locais diversos na cidade, entendidas por ele como sendo de demolição, recomposição, remoção ou transferência e de restauro, visando "providências de caráter radical quando se trata de preservar ou repor a coisa no seu estado original". Podemos entender a presença

\footnotetext{
${ }^{4}$ COSTA, Lúcio. (1958). Conjunto Arquitetônico e Urbanístico - Ouro Preto - MG. Rio de Janeiro: Arquivo Noronha Santos (IPHAN). Apud PESSOA, J.S.B. (1999). Lucio Costa: documentos de trabalho. Rio de Janeiro: IPHAN.
} 
conceitual de Violet Le Duc indicada por Andrade (1993), mas independentemente das vertentes conceituais de restauro, Lúcio Costa se refere à cidade como "um todo", de acordo com a atribuição imposta pelo tombamento, via Decreto Lei 25, conforme nos esclarece Castro (1991).

Percebemos que há diversas compreensões sobre o tema da preservação e restauração, não somente no Brasil. Independentemente das divergências existentes, no caso brasileiro, a essência, as bases fundamentais da compreensão da cidade como "um todo", da percepção de sua materialidade, estética, história encontra-se presente desde o tombamento de Serro. Acreditamos que desde a criação do IPHAN, no que se refere à cidade, há a clareza da percepção da cidade como unidade de relevância artística. 


\subsection{Formação e transformação da cidade}

\section{contextualização}

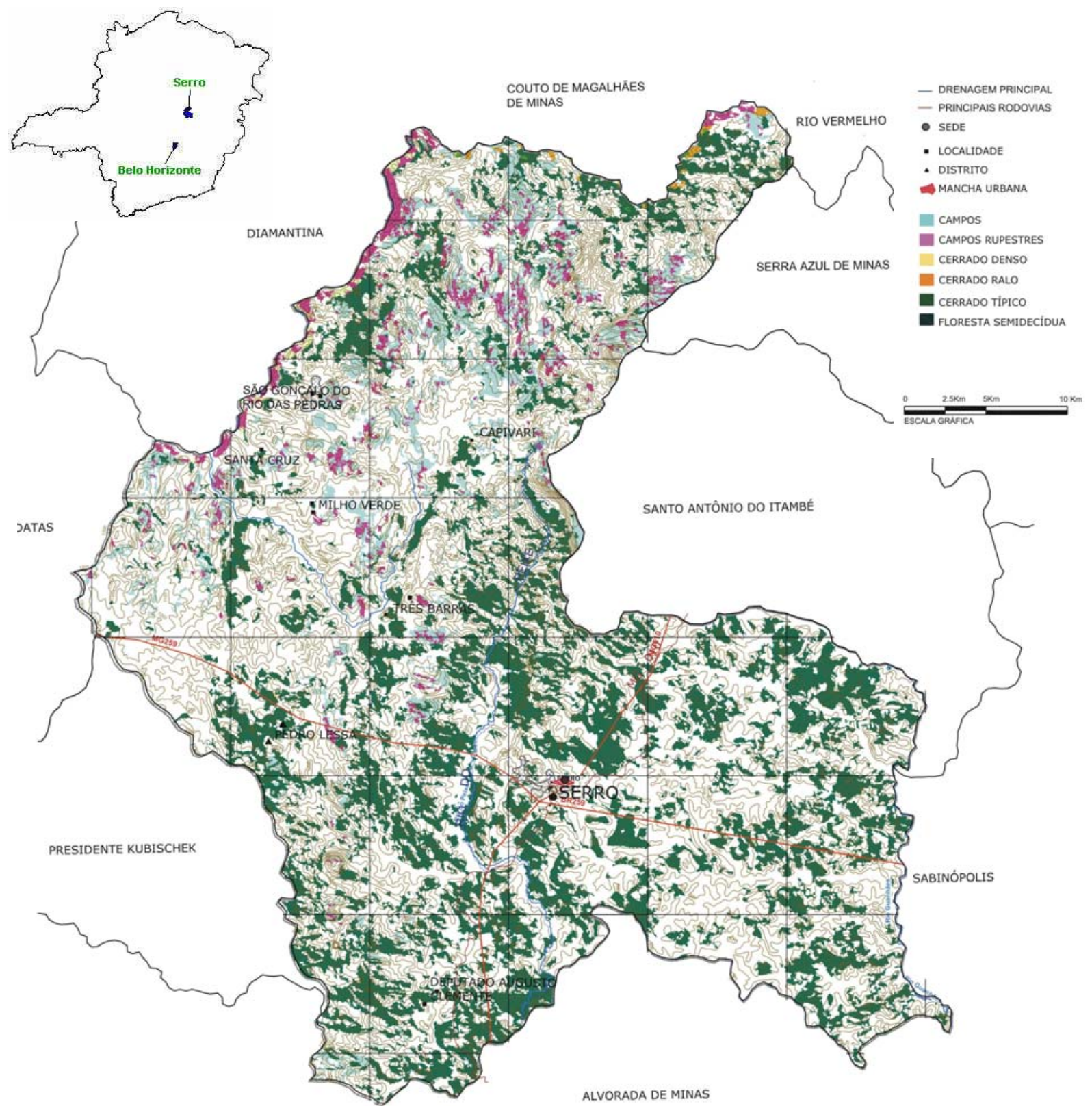

Figura 25. Localização de Serro no Estado e na região de Minas Gerais e principais características da vegetação.

Fonte: Plano Diretor Municipal de Serro (PDM-Serro)- EA UFMG (2006) 
O município do Serro, com altitude de 781m a 940m, geograficamente, pertence à região do Alto Jequitinhonha localizada na serra do Espinhaço, central leste do estado de Minas Gerais. Com uma extensão territorial de $1.214,94$ km², em formato irregular, a região possui vegetação de campo rupestre e de campo de altitude. Há presença constante de matas ciliares e ilhas de vegetação exuberante, ao longo das áreas de escoamento de águas onde o terreno é excessivamente úmido, e em áreas topograficamente mais planas, geralmente com posicionamento litológico determinado pela presença de rochas metabásicas e/ou graníticas. Esta vegetação, associada às áreas mais planas, é característica do Cerrado. O município é notável pela presença marcante de rios e serras, que delimitam sua especial topografia (Figura 25).

\footnotetext{
Esta área compreende a faixa localmente denominada Serra do Veado, Serra da Pedra Redonda e Serra da Bocaina. Exibe um relevo um tanto confuso e mostra uma largura de aproximadamente $12 \mathrm{~km}$. Os cursos d'água são torrenciais, os vales, em $\vee$ muito agudo. $\mathrm{O}$ volume d'água de cada curso é pequeno, porém, em vista do relevo, possui elevado poder erosivo (PROGRAMA MONUMENTA, 2005).
}

Com um formato expressivamente irregular, o território de Serro possui 05(cinco) distritos (Milho Verde - Figura 26 -, São Gonçalo do Rio das Pedras Figura 27 -, Dep. Augusto Clementino - antigo Mato Grosso, Pedro Lessa) e divisas naturais com outros nove municípios - Couto de Magalhães, Diamantina, Datas, Presidente Kubistichek, Alvorada de Minas, Sabinópolis, Santo Antônio do Itambé, Serra Azul de Minas e Felício dos Santos - (Figura 25). 


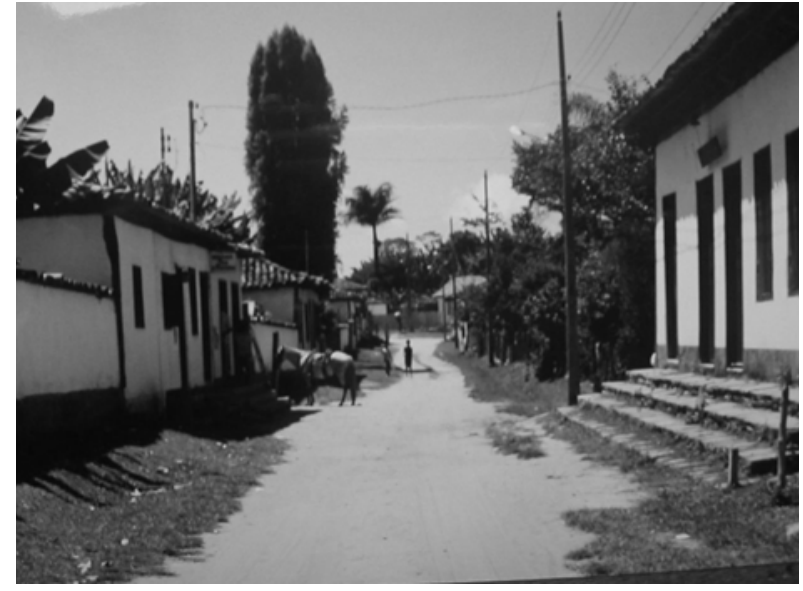

Figura 26. Distrito de Milho Verde.

Fonte: MC Arquitetos (2004)

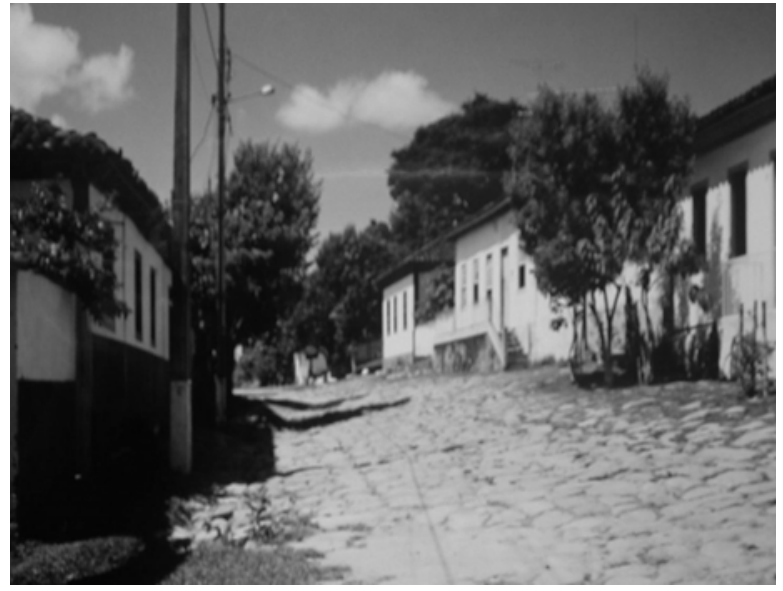

Figura 27. Distrito de São Gonçalo. Fonte: MC Arquitetos (2004)

Regionalmente, a serra do Espinhaço serve como um grande distribuidor de águas. Em Serro, ela inclui as nascentes do rio Jequitinhonha voltado para o norte e dos rios Guanhães e Peixe para o sul, pertencentes à bacia do Rio Doce. E é nesta riqueza de nascentes de rios, sobre solo rochoso, e leitos cristalinos, que no século XVIII "um grupo de exploradores, chefiado pelo paulista Antônio Soares Ferreira, descobriu as minas de ouro do Ivituruí, que significa Serro Frio" (FUNDAÇÃO JOÃO PINHEIRO, 1994).

Em 1711, fundou-se o arraial das Lavras Velhas do Ivituruí, próximo aos córregos do Lucas e Quatro Vinténs. Em 1714, o arraial foi elevado a Vila do Príncipe, e em 1720 teve o privilégio de se juntar a Ouro Preto/Comarca de Vila Rica, Sabará/Comarca do Rio das

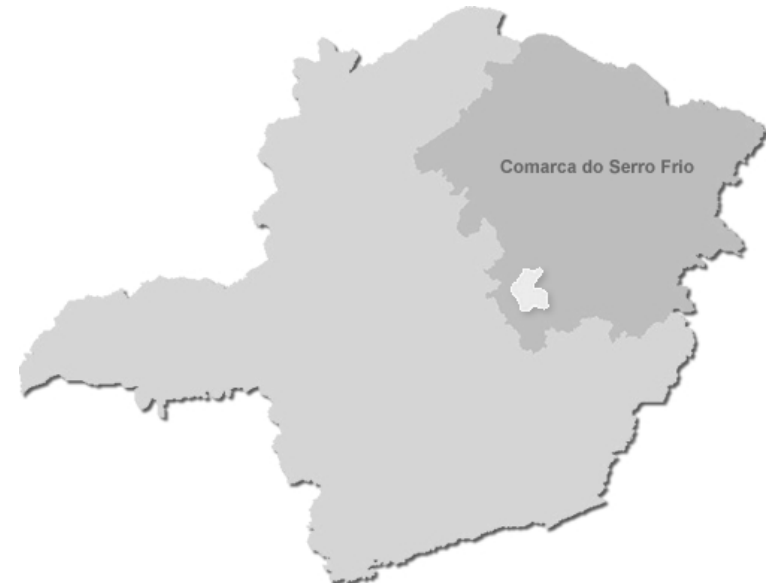

Figura 28. Comarca do Serro Frio e Vila do Príncipe Fonte: EA UFMG (2006), PDM Serro 
Velhas, São João Del Rei/Comarca do Rio das Mortes, como sede, "cabeça de comarca", ou como diz Saint-Hilaire (1975), capital da inaugurada comarca do Serro Frio (Figura 28), com a importante responsabilidade jurídico-administrativa sobre quase todo o norte e nordeste da capitânia de Minas Gerais.

Vila do Príncipe, com a consolidação da exploração aurífera e da autoridade política, passou a ter maiores investimentos em sua estrutura urbana decorrentes da ampliação do poder religioso e político administrativo das riquezas minerais. Isso possibilitou maiores investimentos para a arquitetura com melhor técnica e riquezas de detalhes. Foram construídos uma casa de fundição, vários templos religiosos, imponentes sobrados residenciais, dentre outras produções urbanas.

No início do século XIX, com o declínio da mineração, ficaram no Serro exploradores de maior vulto, com condições e tecnologia para grandes minerações. Os pequenos partiram para a produção agrícola e pecuária, nas terras do sul e leste do município, que se mostravam mais férteis e adequadas a este uso. Assim, a base da economia do município passou a agropecuária, e a projeção e autoridade ficaram vinculados ao poder administrativo e judicial que ainda detinha de toda a região, por ser sede da Comarca. (FUNDAÇÃO JOÃO PINHEIRO, 1994, p.140).

Com a independência do Brasil, foram instaladas em Vila do Príncipe pequenas fábricas de ferro e aconteceu maior dinamização comercial, possibilitando a segurança necessária para que, em 1938, a vila adquirisse o foro de cidade com a denominação de Serro. 


\section{Desenvolvimento urbano}

A cidade do Serro mantém atualmente um traçado básico com referência provavelmente da metade do século XVIII, quando da consolidação urbanística da Vila do Príncipe, já como sede da Comarca do Serro Frio. A ocupação prevaleceu na encosta de pequenos morros, margens dos ribeirões Quatro Vinténs e Lucas e cursos d'águas com riquezas auríferas. Desta ocupação, de acordo com a Fundação João Pinheiro (1994), "surgiram a pouca distância um do outro, os arraiais chamados de Baixo e de Cima [...] que se aglutinaram num só arraial" em curto tempo, devido a ocupação de novos ranchos ou casas rústicas que intermediavam estes dois núcleos pioneiros juntamente com a área da Praia.
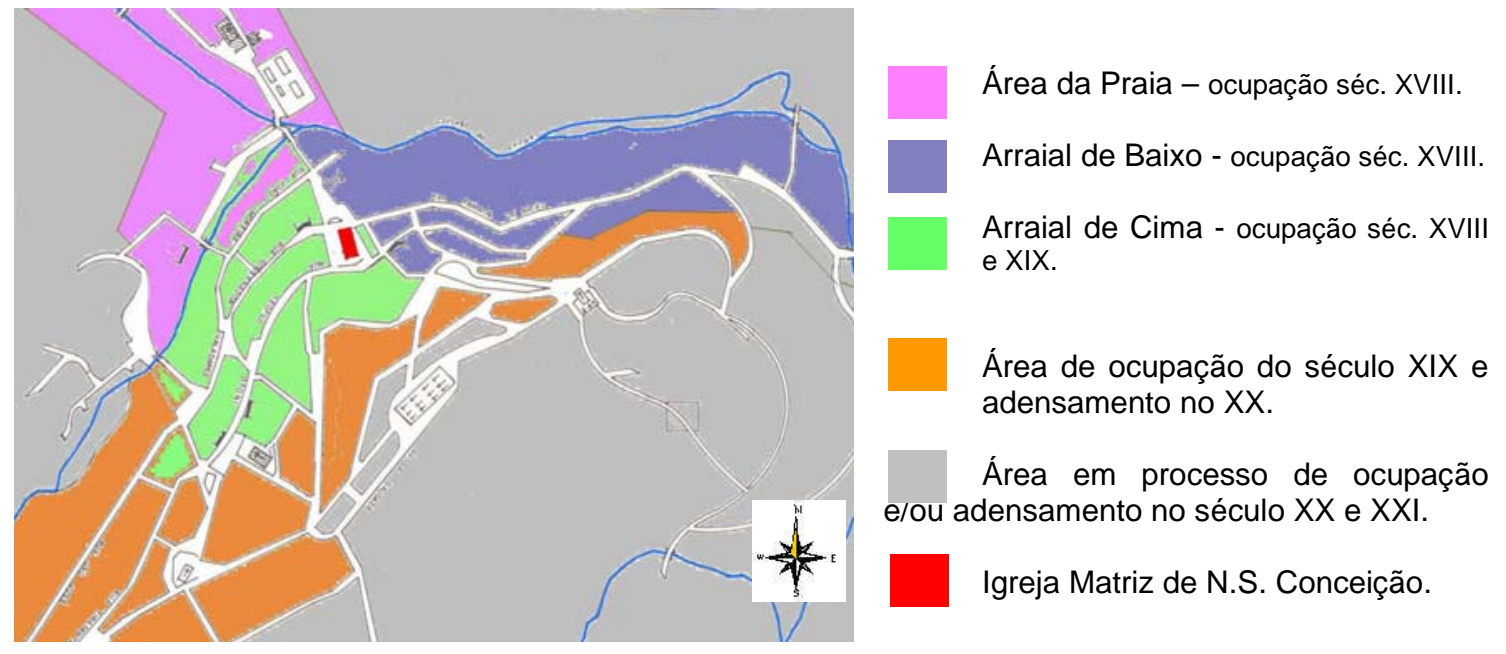

Figura 29. Croqui das etapas ocupação de Serro. Elaborado a partir de interpretação textual Fonte: adantado de (FUNDACÃO JÕÃO PINHEIRO 1994)

Entendemos que a topografia atrelada à formação mineral do solo, condicionou a ocupação da área por exploração principalmente de ouro e diamante, 
e representa um dos fatores determinantes para a forma de apropriação do território da cidade de Serro (a figura 31 encontra-se invertida, em relação ao norte, para melhor visualização das vias marcadas nela e na imagem da figura 30).

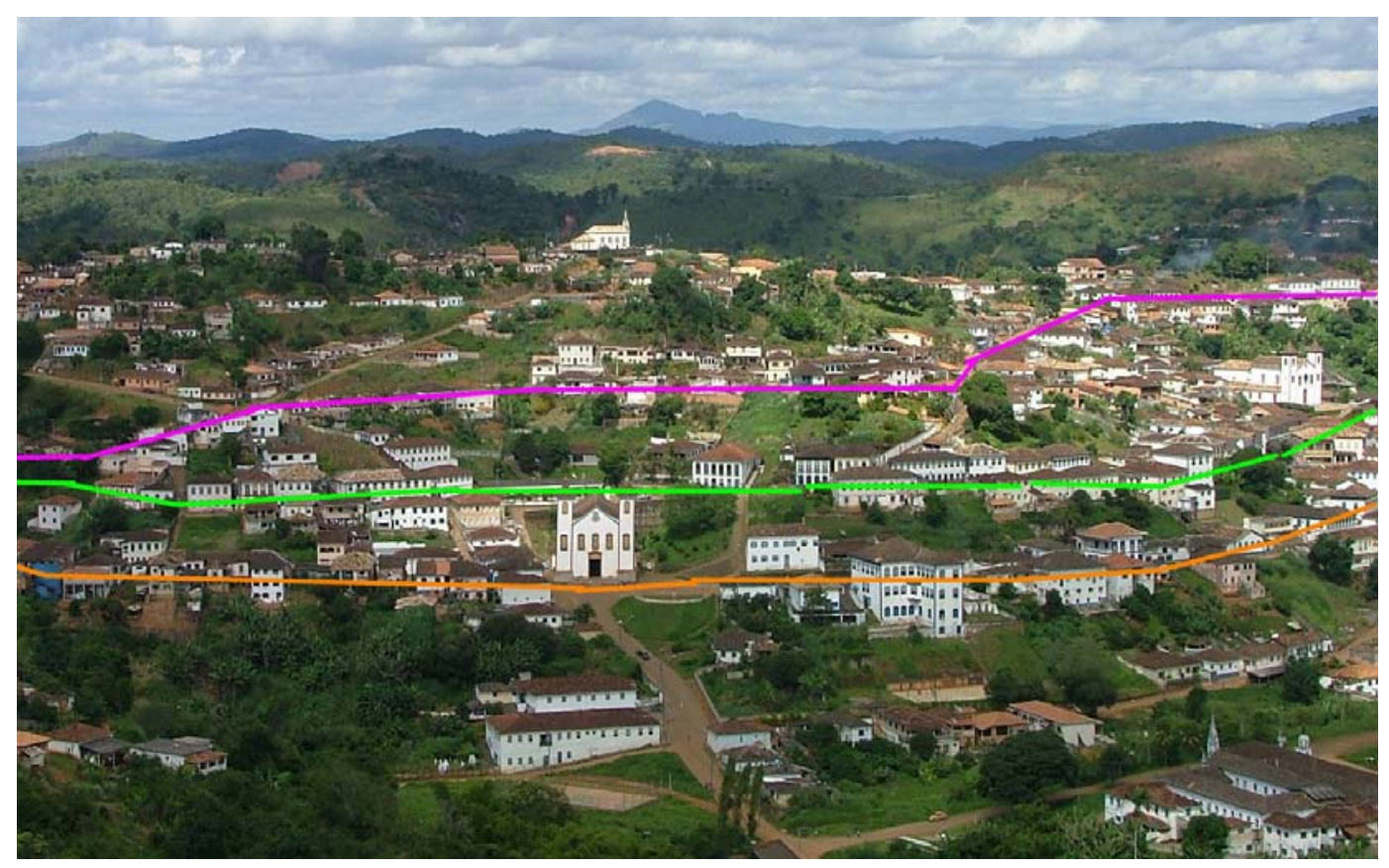

Figura 30. Vista panorâmica de Serro destacando principais vias longitudinais de formacão urbana de Serro. Fonte: adaptado de (FUNDACÃO JOÃO PINHEIRO 1994)

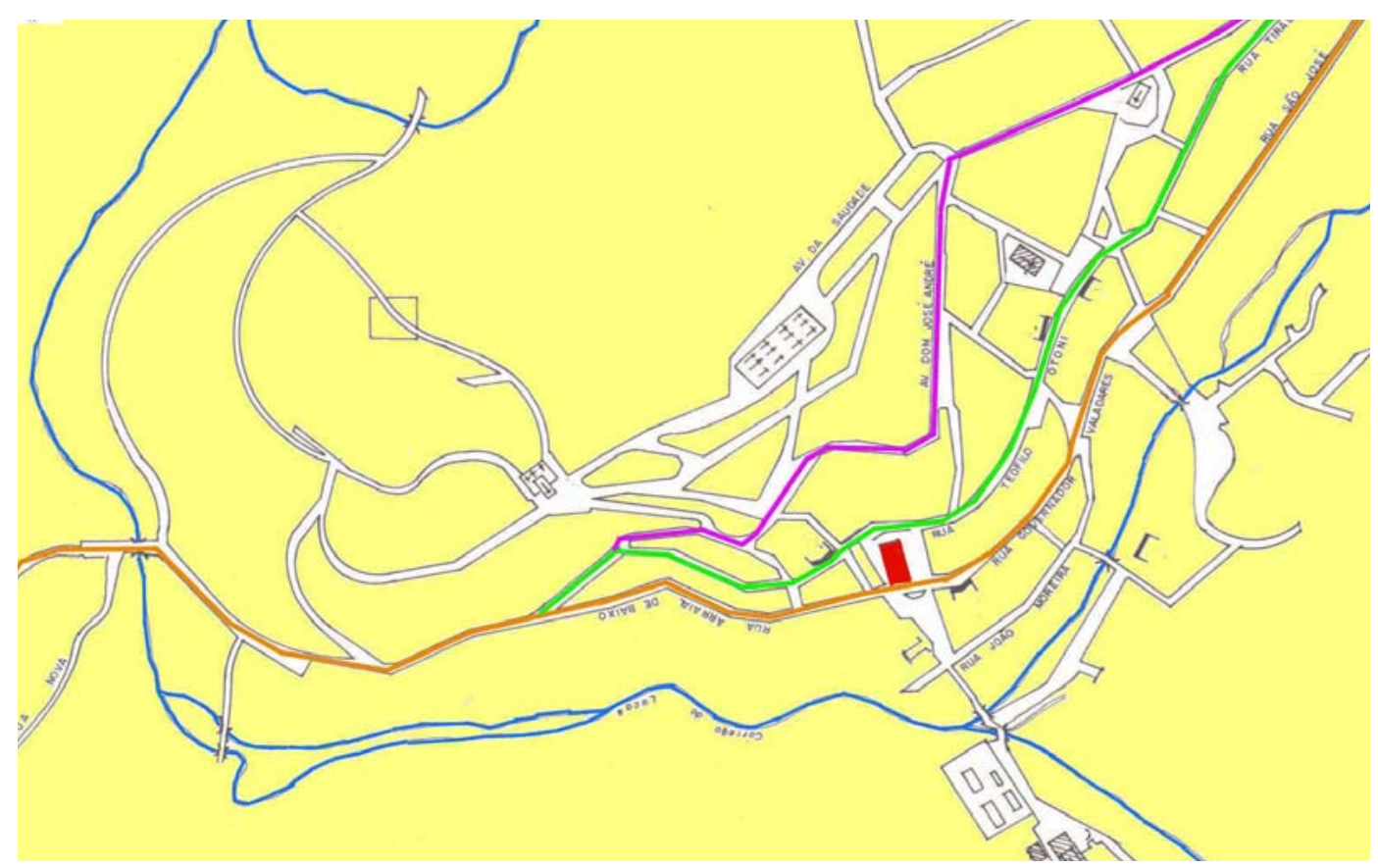

Figura 31. Vista panorâmica de Serro destacando principais vias longitudinais de formação urbana. Fonte: adaptado de (FUNDAÇÃO JOÃO PINHEIRO 1994) 
O crescimento da cidade seguiu uma tendência longitudinal, na direção leste-oeste, assinalada por três longas vias, representadas pela tradicional rua Direita, rua de Cima e rua do Corte, onde se concentravam os serviços de abastecimento da cidade. Estas três vias possuem como ponto principal de confluência, o local de chegada na cidade pelo antigo caminho da Estrada Real (sentido Diamantina), e se encontram novamente na saída, sentido Guanhães.

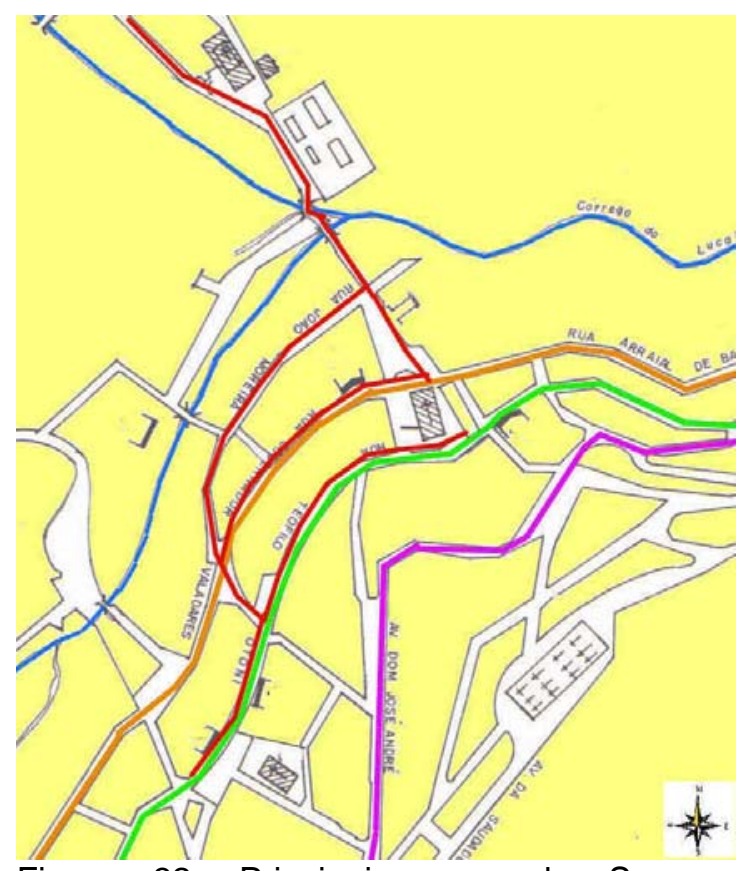

Figura 32. Principais ruas do Serro consolidadas no século XVIII

Fonte: adaptado de (FUNDAÇÃO JOÃO PINHEIRO 1994)

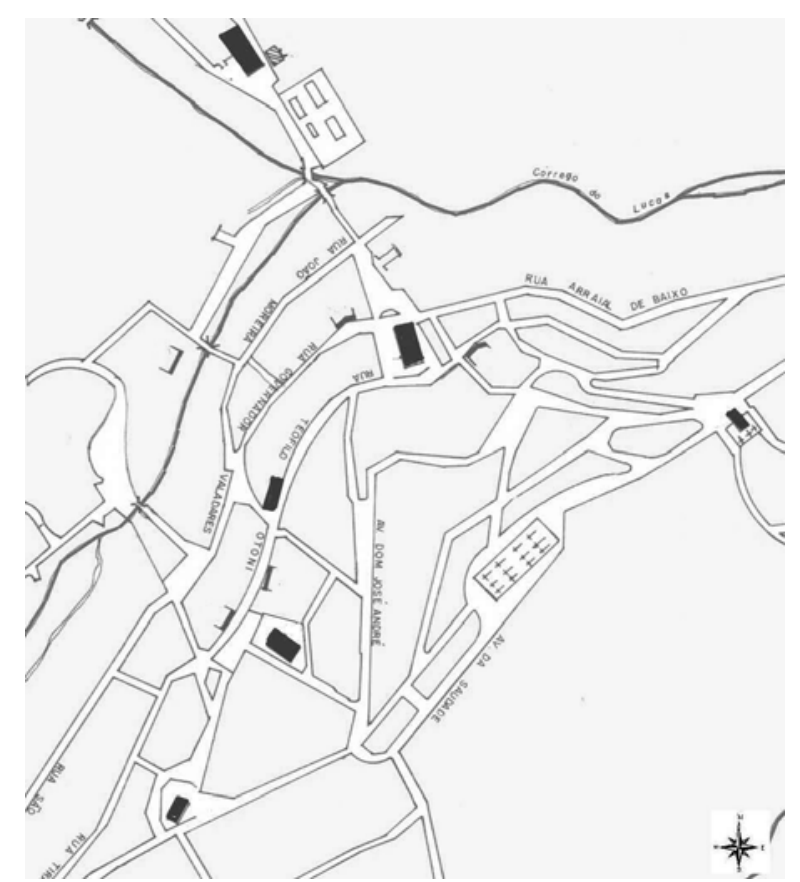

Figura 33. Participação das Igrejas setecentistas do Serro na estruturação urbana

Fonte: adaptado de (FUNDAÇÃO JOÃO PINHEIRO 1994)

Ainda na primeira metade do século XVIII, a Vila do Príncipe passou por significativa expansão. De acordo com Silva (1928), nessa época algumas das principais ruas do Serro já estavam consolidadas, como a rua das Flores ligando o Arraial de Baixo ao Arraial de Cima, prosseguindo até a entrada da cidade. A rua de Cima, com início atrás da Matriz, a rua de Baixo ou rua da Cadeia, que se encontrava com a rua Direita na altura da antiga rua Cruz Machado (em frente à 
igreja de Nossa Senhora da Purificação - demolida) para alcançar, depois, o largo da Carreira ou da Cavalhada, atual praça João Pinheiro - linhas vermelhas no mapa - (figura 32).

A providência em construir várias igrejas, ainda no início do século XVIII, colaborou para maior adensamento da vila. De acordo com a Fundação João Pinheiro (1994), "a edificação de cada templo propiciava sempre o agenciamento de novos logradouros e novas casas", de maneira que era o Senado da Câmara que promovia o arruamento, calçamento, limpeza e bom aspecto da vila. Além da igreja Matriz que representava o ponto mais importante de convergência da vida social e eixo central urbano de Serro, foram construídas, ao longo do século XVIII e XIX, mais cinco igrejas que colaboraram para a fixação de uma trama urbana mais coesa (figura 33), exatamente como chegou em nossos dias, sem grandes alterações até aproximadamente a década de 1980, quando o adensamento urbano se intensificou através de novas construções e parcelamento do solo.

Os portugueses, no século XVIII, haviam desenvolvido um modelo padronizado para o traçado das novas vilas no interior, mas a implantação desses novos padrões urbanos nas regiões de mineração foi um dos maiores desafios da Coroa portuguesa na colonização do Brasil. Nesse sentido, Vasconcellos (1983) esclarece que, no início, as povoações primeiras das áreas mineradoras uniam os indivíduos em torno de uma única capela, de construção precária, núcleo da povoação nascente, e ponto de referência do lugar - em Serro, a igreja Santo Antônio, atual Nossa Senhora da Conceição - (figura 34). Aí, o povo se reunia em festas, todos sem diferenças maiores, igualmente esperançosos de novas 
conquistas e homogêneos. Com o progresso do lugar, uns se enriqueciam e outros se viam pobres. Surgiam então novas atividades, como o comércio e um outro tipo de circulação de pessoas diferentes daquelas que estavam habitando naquela área. Começavam a se definir as classes sociais: pobres, ricos, trabalhadores braçais, comerciantes, administradores, brancos, pretos. A localidade tendia a se estabilizar, exigindo paróquia provida de vigário próprio.

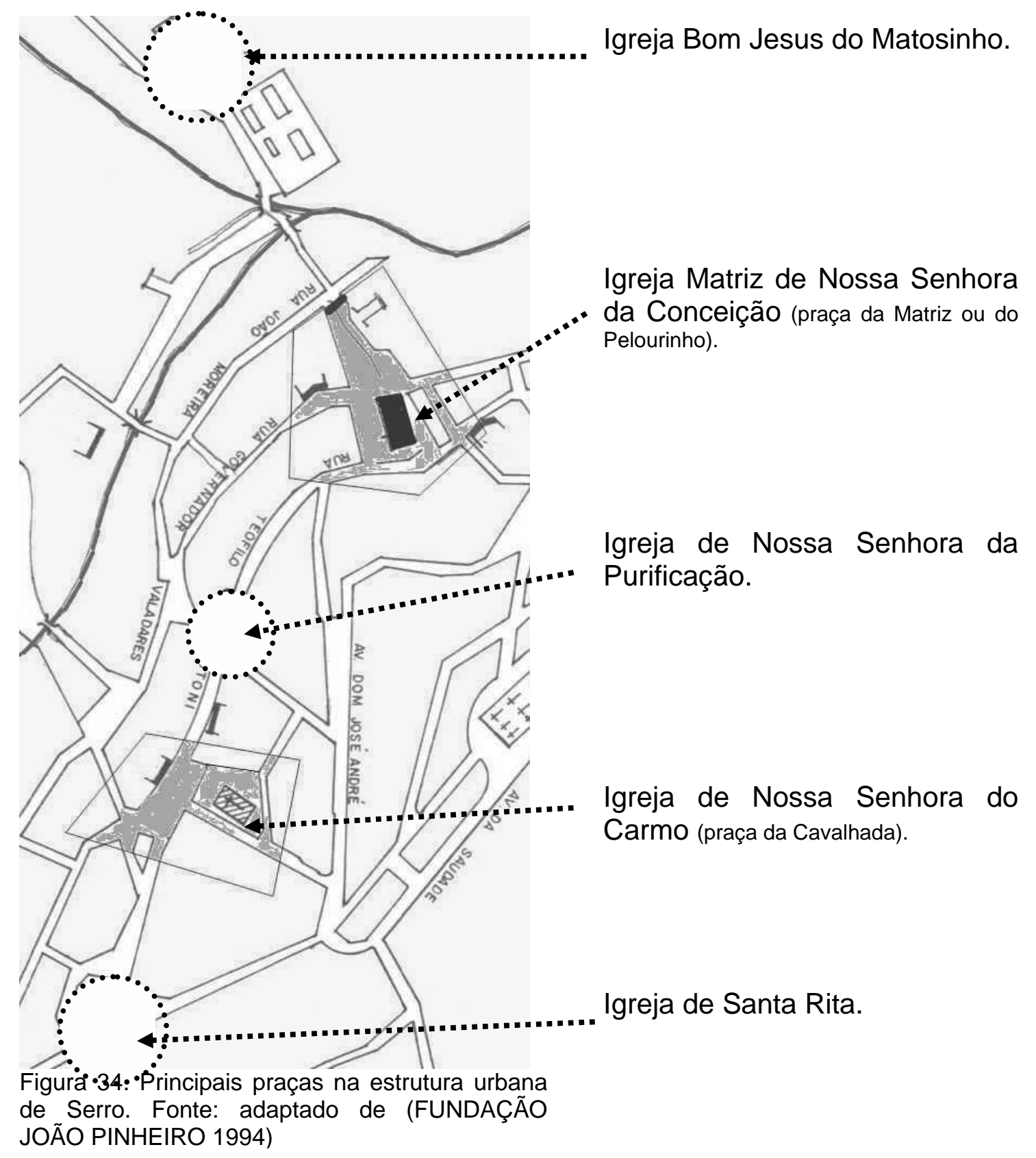


Neste contexto, a classe de melhores condições financeiras construía a matriz. É interessante que a invocação normalmente escolhida pelos ricos se apegava aos poderosos, diretamente ao rei, erigindo suas matrizes ao Santíssimo Sacramento. Vasconcellos (1983) diz que a evocação acentuada à figura da virgem Maria podia estar atrelada ao fato de a figura feminina ser pouco presente na capitania, principalmente da mulher branca.

$\mathrm{Na}$ estruturação dos povoados a partir das igrejas e capelas, ocorria que, às vezes, a matriz era erigida por um grupo com menos riqueza, mas nesta situação existia um grupo líder que comandava os outros grupos como numa federação. Ficando, assim, a matriz com o altar principal ao Santíssimo Sacramento, e os vários altares laterais tão presentes nas igrejas mineiras, às associações filiadas. A partir de então, com um maior avanço do lugar como um todo, o progresso ampliava a estratificação social existente, surgindo conflitos e uma convivência heterogenea entre as já formadas classes sociais. A harmonia que então existia era quebrada, e cada grupo resolvia a seu modo os problemas existentes. Uns se dissolviam, outros se empenhavam na construção de novas capelas (VASCONCELLOS, 1983).

Foi neste período que aconteceram as mais importantes obras arquitetônicas de origem setecentista de Minas Gerais, que representou uma fase de curta duração, logo superada pelo declínio da economia do ouro. Esta realidade resultou no empobrecimento geral das classes sociais existentes, que, sem mais condições financeiras de continuarem seus projetos e construções, concentraram seus esforços em benefício do templo principal, a Matriz. 
Considerando-se esse período de riquezas arquitetônicas - de acordo com a Fundação João Pinheiro (1994) - no Serro, em 1738 já havia iniciado o calçamento de ruas como a ladeira da Matriz, rua de Cima, rua Direita, e realização da "urbanização" do largo da Cavalhada que deveria ser transformado em praça pública "para recreio e passeio dos moradores, exercício de soldados ou paisanos, festejos", dentre diversas atividades. Até o final do século XVIII foram calçados vários trechos entre o largo da Matriz e da Cavalhada, além de outros pontos já povoados.

Esse tipo de tratamento urbano não era muito comum no do período colonial em Minas Gerais; Diamantina, por exemplo, até o final do século XIX tinha pavimentado apenas suas principais vias. Saint-Hilaire (1975), quando visitou a Vila do Príncipe (Serro), em 1817 enfatizou a boa aparência dada ao local.

\begin{abstract}
As ruas são pouco numerosas, e, na maioria calçadas. As principais estendem-se de leste a oeste, paralelamente à base do morro [ao córrego quatro Vinténs]; e cada uma delas acha-se assim traçada em todo o comprimento, quase no mesmo plano [acompanhando a curva de nível]. Só as ruas transversais seguem o declive do morro; tem porém pequena extensão (SAINT-HILAIRE, 1975, p.145).
\end{abstract}

Entretanto, quando da visita de Saint-Hilaire ao Serro, já estava instalada a crise relativa ao declínio da produção aurífera, resultando em expressivo esvaziamento da vida social e econômica da Vila. Ainda assim, o visitante, em seus relatos, afirma que apesar de pouco requinte nos interiores das casas, a vida social era dinâmica, as pessoas se vestiam com bom gosto e a qualidade das apresentações musicais em Vila do Príncipe era superior à de qualquer vila de mesmo tamanho, do norte da França. 
Serro teve o privilégio de se integrar simultaneamente ao complexo aurífero e pastoril favorecido pelo tipo de solo e localização como divisor de águas, pertencente à bacia do Jequitinhonha - cerrado e a bacia do Rio Doce/ Mata Atlântica. Com isso se resguardou da decadência súbita que sucedeu à exaustão do ouro. As pastagens da região observadas por Saint-Hilaire (1975) serviam ao gado leiteiro, e, com a ampla produção leiteira, tem-se mesclado a tradição do queijo Minas à do queijo do Serro (atualmente registro do patrimônio imaterial mineiro). Portanto, o esvaziamento financeiro de Serro foi conduzido com certa naturalidade, tendo a seu favor, ainda, o suporte que possuía, principalmente pela manutenção de sua centralidade diante da comarca do Serro Frio, mesmo após sua elevação à cidade em 1838.

Outro fator de relevância para a sustentabilidade econômica de Serro é a sua localização geográfica estratégica em meio às estradas de comunicação com os núcleos mais ao norte de Minas, inclusive Diamantina. Tal posição de centro regional comercial se manteve ao longo do século XIX, até a implantação da ferrovia construída em direção a Diamantina, com importante estação nesta cidade.

Entendemos que a exclusão de Serro do circuito ferroviário representou perdas à sua economia, podendo ser até mesmo maiores do que aquelas referentes ao declínio do ouro. No início do século XX, momento em que a modernidade se adentrava, Serro ficou de fora dos investimentos industriais e ferroviários. A partir de então, "a cidade do Serro pouco ou nada mais se desenvolveu, até chegar aos nossos dias como simples imagem urbana e arquitetônica de um passado de prosperidade" (FUNDAÇÃO JOÃO PINHEIRO, 1994, p.156). 
Principais espaços livres (praças e ruas)

Para maior aproximação do objeto de estudo, apresentamos duas das principais praças da cidade de Serro. A praça da Matriz por ter sido, durante o século XVIII, o centro religioso, administrativo e social da cidade e a praça João Pinheiro, por ter assumido plenamente esta função a partir do século XX.

\section{Praça Getúlio Vargas (Praça da Matriz ou Largo do Pelourinho)}

A praça da Matriz (Figura 37), com a denominação atual de praça Getúlio Vargas, tradicionalmente representa espaço de função social diversa. Como podemos observar - Figura 35 -, possui um espaço mais amplo do que se apresenta atualmente, e perdeu o passadiço (Figura 36) que existia na base da ladeira de acesso a ela, que fazia parte de seu fechamento, alterando suas características. Abriga a Matriz da cidade desde o século XVIII, e até o início século XX manteve em sua conformação a Casa de Câmara, (edificação de arquitetura modesta, sem impacto espacial, mas de importância administrativa - Figura 38 -). 


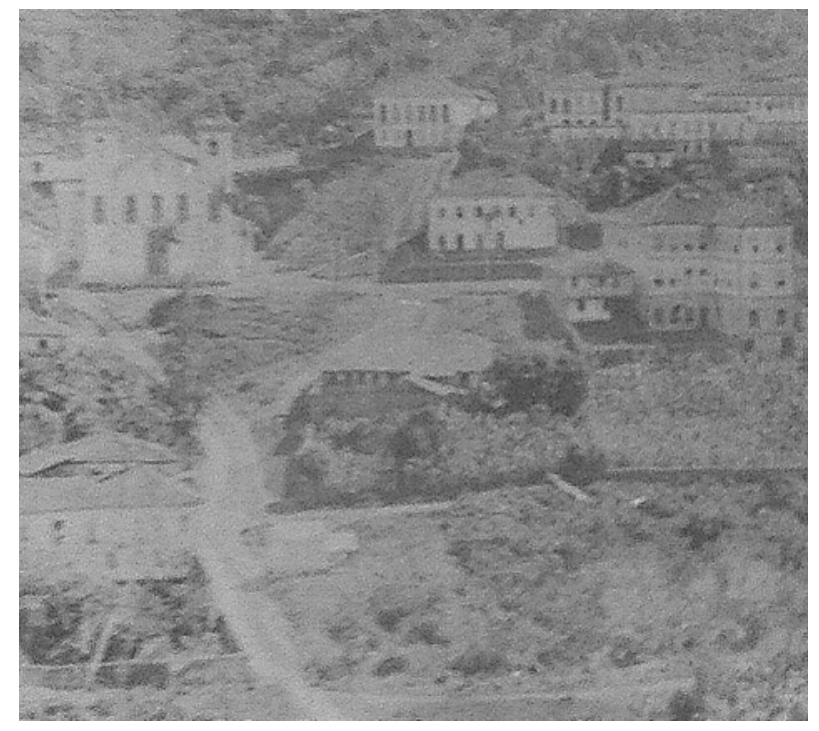

Figura 35. Praça da Matriz sem ocupação de parte de sua área antiga, e ainda com o passadiço Fonte: IPHAN (2006)

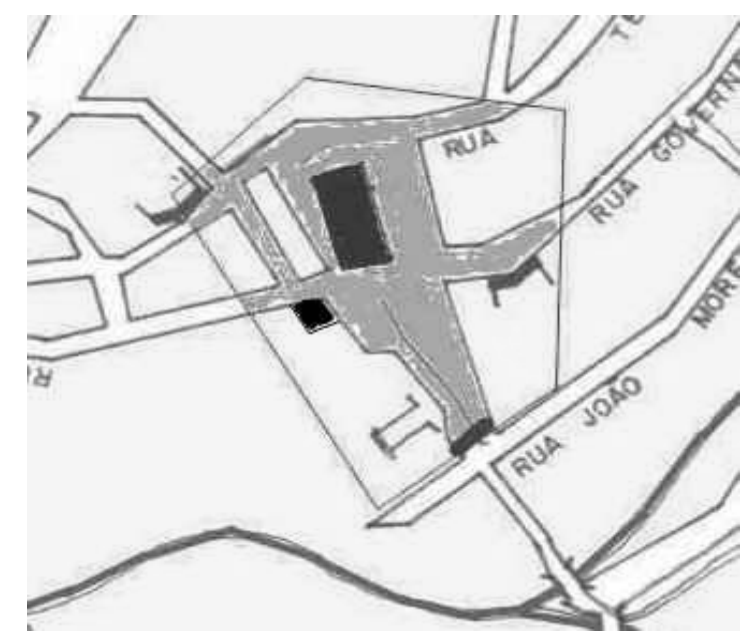

Figura 37. Praça da Matriz, Casa de Câmara local do antigo passadiço, Igreja Matriz Fonte: adaptado de (FUNDAÇÃO JOÃO PINHEIRO 1994)

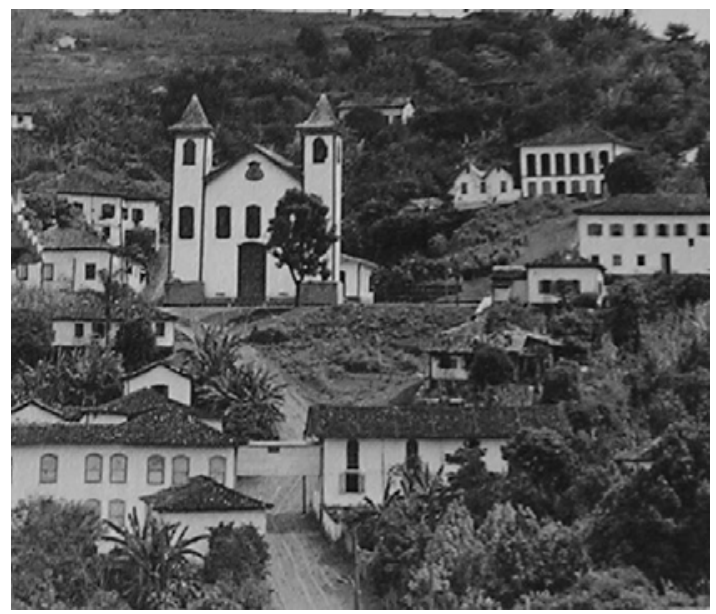

Figura 36. Praça da Matriz e passadiço do Colégio N.S. Conceição Fonte: IPHAN (2006)

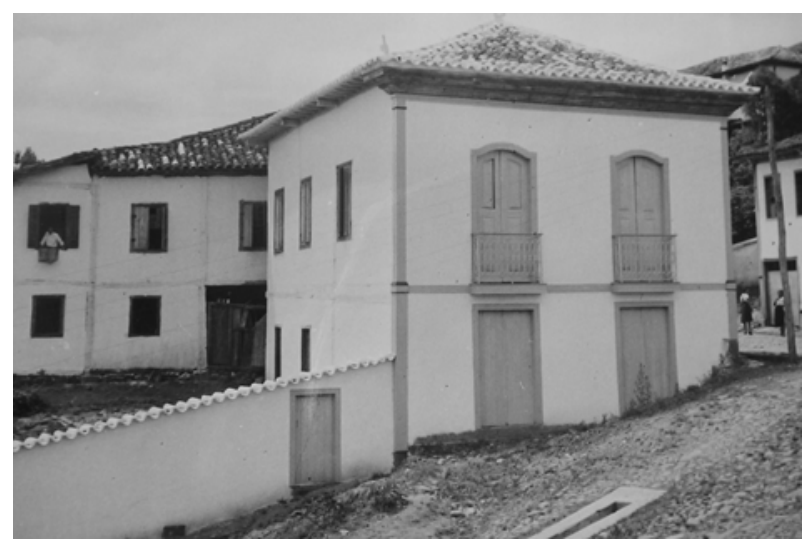

Figura 38. Casa de Câmara de Serro - vista lateral direita

Fonte: IPHAN (2006) 
Por conseqüência, o largo da Matriz, símbolo da autoridade religiosa, e o Largo do Pelourinho, símbolo da autoridade civil pública, pertenciam à mesma praça (Figura 39 à Figura 41). A importância tradicional do largo é reforçada pelo seu papel de ligação entre o primitivo núcleo da Praia com os antigos arraiais de Baixo e Cima, representando um dos mais importantes pontos de distribuição de fluxos da cidade. Esta característica é atualmente percebida com clareza, pois as diferentes "partes" da cidade mantêm ainda características arquitetônicas distintas entre si.

A importância do poder misto (religioso e civil), que se interceptavam nesta praça é citado por Santos (1978), quando da votação, no século XVIII, para a criação da paróquia do Arraial do Tejuco (Diamantina), na recepção dos mais de 90 (noventa) eleitores que ocorreu na sacristia da Matriz de Nossa Senhora da Conceição, porque a câmara não tinha sala para receber este número de pessoas, demonstrando a intercessão entre os poderes administrativos da região.

Entretanto, apesar de manter ainda na atualidade importância destacada no universo social e religioso da cidade, por abrigar a igreja Matriz, o centro de referência administrativo e social está consolidado na praça João Pinheiro, que possui ainda forte referência religiosa com a presença marcante da igreja Nossa Senhora do Carmo, onde acontecem todas as cerimônias religiosas de interesse da administração pública, além de solenidades (como inauguração e posse do corpo administrativo da Pontifícia Universidade Católica - Campus Serro). 

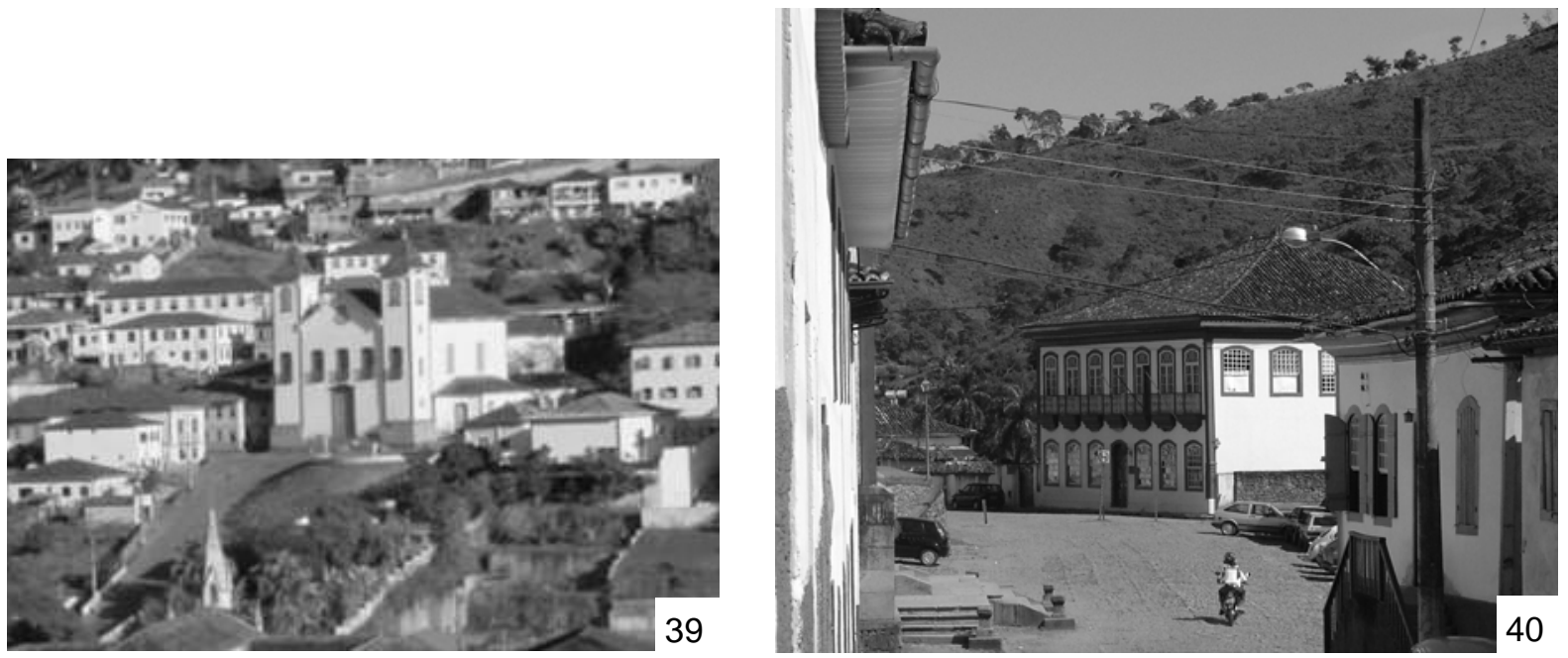

Figura 39 - Figura 40. Praça Getúlio Vargas

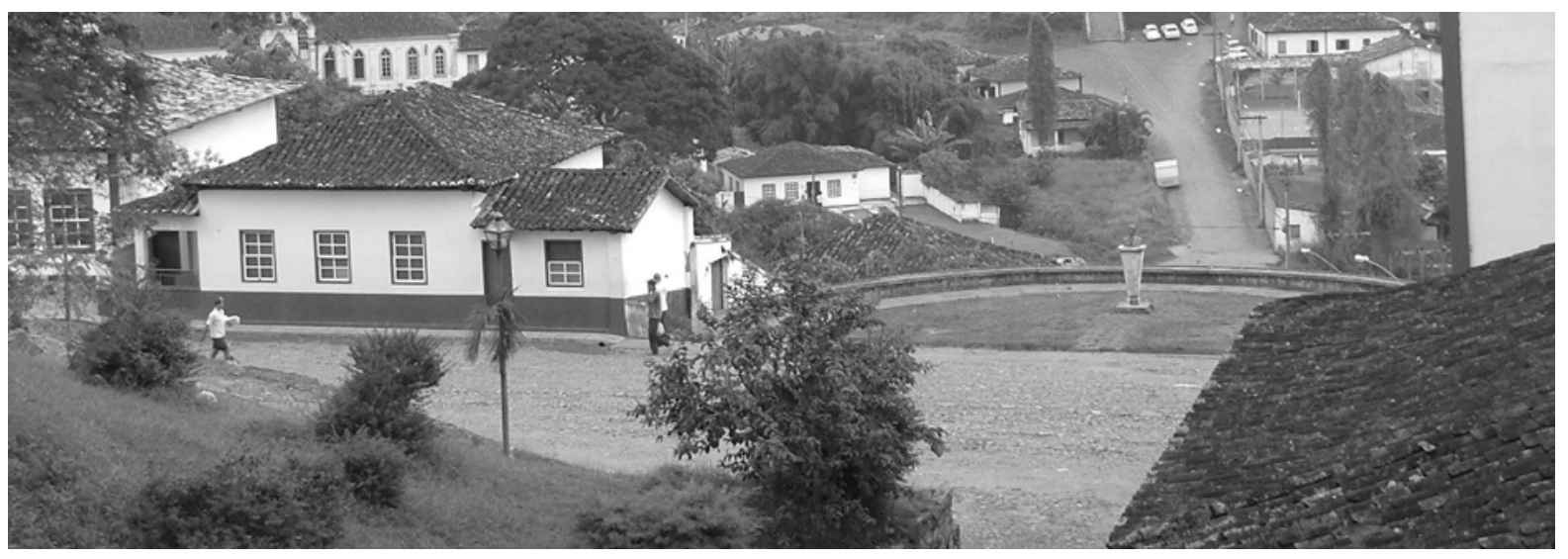

Figura 41. Praça Getúlio Vargas - antigo Largo do Pelourinho

\section{Praça João Pinheiro (Largo da Cavalhada)}

A praça João Pinheiro (Figura 44), tradicionalmente, representa o largo de ligação entre a igreja Santa Rita e igreja Nossa Senhora do Carmo. O largo da Cavalhada, 
como era conhecido, passou por diversas alterações ao longo dos séculos, tendo em vista o crescimento e demandas políticas sociais da cidade.

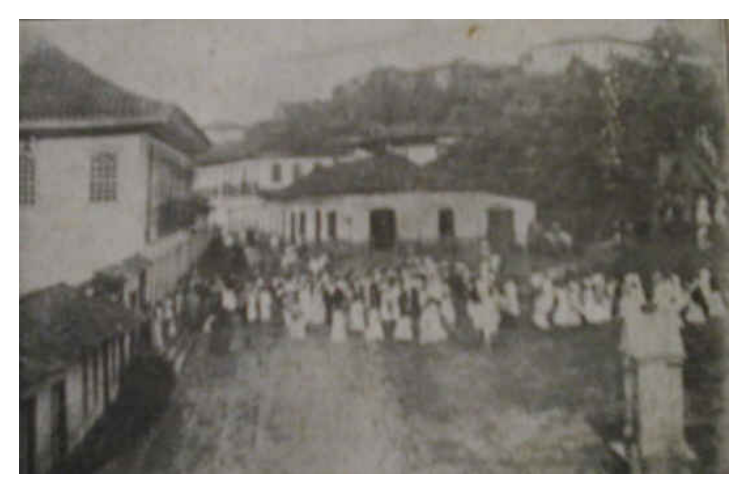

Figura 42. Praça João Pinheiro Fonte: IPHAN (2006)

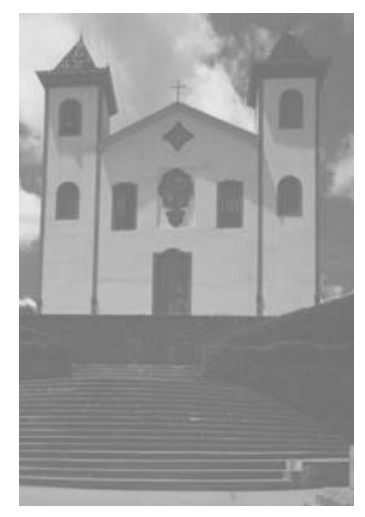

Figura 43. Praça João Pinheiro - Igreja Nossa Senhora do Carmo

Fonte: Segawa (2004)

Até o início do século XX, a praça João Pinheiro mantinha características de amplo "terreiro" onde se treinavam as milícias durante o século XVIII. Sua configuração era de uma ocupação natural, e o perfil topográfico acompanhava a declividade natural do terreno, até o encontro com a base da escadaria de acesso à igreja do Carmo (Figura 42 e Figura 43). Ao longo do século XX, passou por modificações que alteraram a configuração do espaço expressivamente. O que era, anteriormente, um amplo largo sem desnível, foi transfigurado para "tabuleiro" em 1943, com nível único em seu piso e desnível variável em relação à rua, construída a partir da definição de limites para uma nova praça, mantida até a atualidade (Figura 45 e Figura 46).

Essa transformação, além de ter criado uma rua com "caixa" definida em frente ao largo, bloqueou o acesso direto deste com a rua do Corte, que ocorria 
através do "Beco do Carmo", que se liga atualmente à praça João Pinheiro por degraus. A praça está passando por novo processo de transformação a partir de projeto do Programa Monumenta, que, apesar de modificações, parece que está mantendo o partido atual da praça. Seria esta a melhor alternativa?

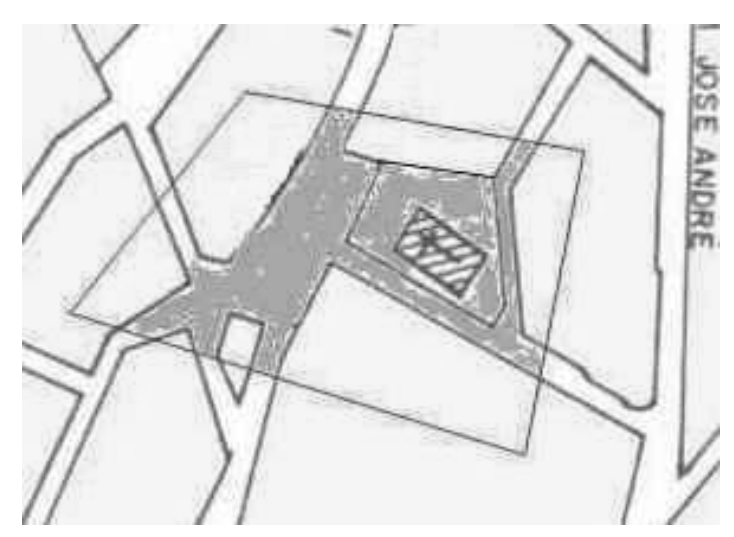

Figura 44. Praça João Pinheiro e Praça do Carmo. Fonte: adaptado de (FUNDAÇÃO JOÃO PINHEIRO 1994)

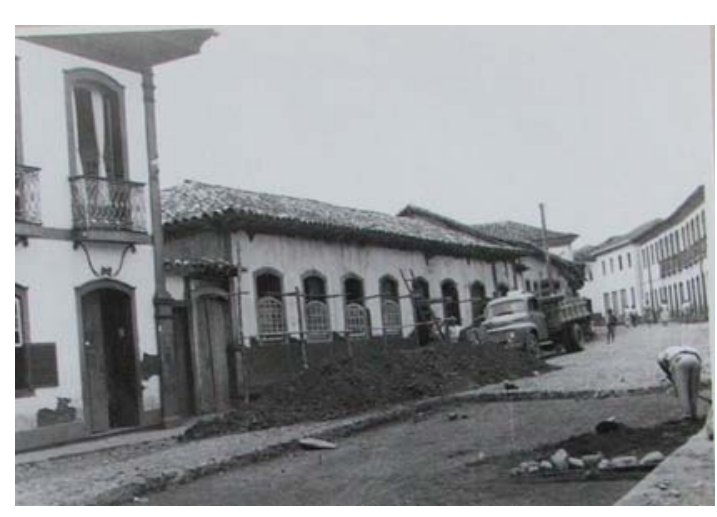

Figura 45. Praça João Pinheiro - após reforma de 1945

Fonte: IPHAN (2006)

Esta praça representa importante ponto de ligação com o antigo largo da Igreja Franciscana da Purificação (demolida), hoje praça Dom Epaminondas, e conexão direta, através de 52 (cinqüenta e dois) degraus, com o largo da igreja de Santa Rita (desnível de aproximadamente 100 metros), que representa o símbolo da cidade do Serro e implantação barroca, assim como da igreja de Nossa Senhora do Carmo, também em cota de nível superior à da Rita

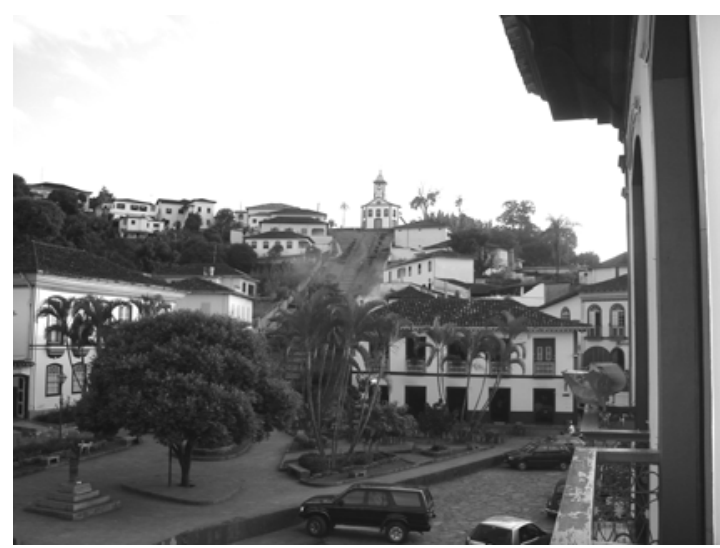
Figura 46. Praça João Pinheiro - Igreja Santa antiga da praça Cavalhada, e está edificada em uma pequena praça, 
[...] e para lá se sobe por uma escadaria bastante alta (...), só é pavimentada em parte; no entanto, é de aspecto alegre e regular; as casas dispostas em seu perímetro são limpas e bem construídas; e finalmente, embelezada pela vegetação dos morros que a dominam por todos os lados (SAINT-HILAIRE, 1975, p.146)

Apesar de, desde a visita de Saint-Hilaire em 1817 até a atualidade, a cidade ter crescido e adensado, ainda é possível perceber vegetação envolvendo a igreja Nossa Senhora do Carmo (Figura 47 e Figura 48).

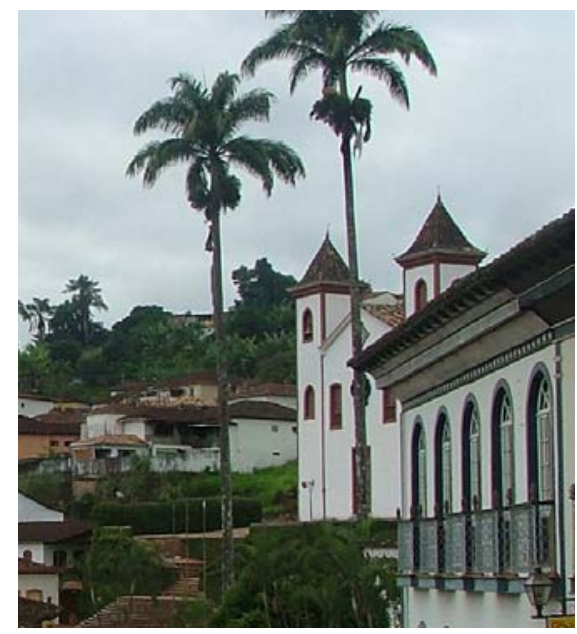

Figura 47. Entorno da Ig. N.S. Carmo

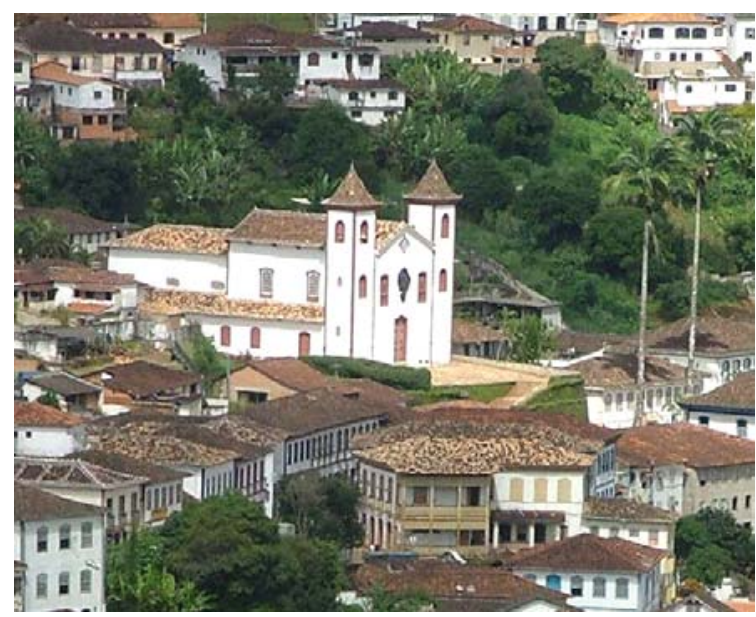

Figura 48. Igreja N.S.Carmo inserida no conjunto urbano

A praça João Pinheiro representa, neste século, a principal praça do Serro; até o final do século XVIII estava praticamente na periferia da malha urbana. Atualmente, como ponto de encontro de manifestações populares, religiosas e políticas, mantém a função de praça conforme conceito tradicional e origem do espaço; sempre teve a igreja Nossa Senhora do Carmo em seus limites e, a partir do século $X X$, recebeu o poder administrativo local, a prefeitura, consolidando destaque diante da estrutura urbana da cidade (com isso a praça da Matriz perdeu importância, passando a praça João Pinheiro a receber a intercessão do poder 
religioso e político, e a igreja de Nossa Senhora do Carmo a servir de local das solenidades religiosas de interesse do poder político local).

Entendemos que esse espaço mantém seu vigor tradicional de uso social e comunitário, expandindo a concentração de pessoas do antigo largo da Purificação, atual praça Dom Epaminondas; e tendo em vista a demolição da igreja de Nossa Senhora da Purificação, na década de 1930, passou a ter palanques montados no local, sustentando assim a referência como marco de concentração de pessoas em festividades importantes para a cidade (festas religiosas, shows musicais, comícios políticos, solenidades de homenagens a autoridades e personagens ilustres, solenidades de inauguração e lançamento de obras e projetos de

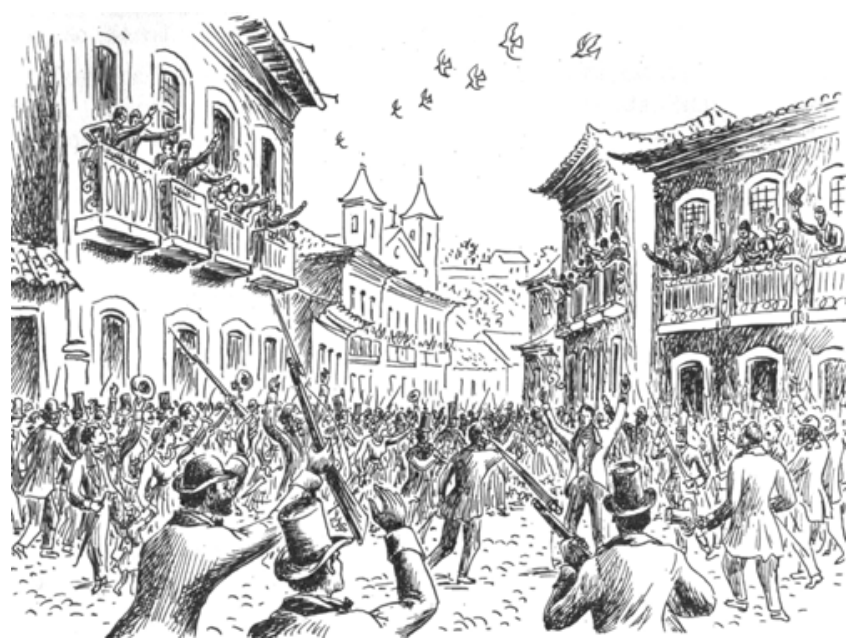

e Figura 49. Manifestação pela República no Brasil - vista do Largo da Purificação em direção ao Largo da Cavalhada - Atual Rua Dr. Antônio Pires. Fonte: Chagas (1978) destaque político e municipal), ou seja, todos os eventos importantes públicos acontecem, total ou parcialmente na praça João Pinheiro (Cavalhada) em conexão com a praça Dom Epaminondas (Igreja da Purificação), envolvendo completamente a atual rua Dr. Antônio Pires, que as conecta (Figura 49). 


\subsection{A preservação e a não preservação}

A memória é uma capacidade seletiva, ou seja, para se lembrar é preciso esquecer. O poder de trazer à memória não é algo natural, mas uma conquista, uma criação que demanda esforço intelectual, pelo o qual o indivíduo se apropria de seu passado coletivo ou individual. Entendemos que o conjunto de meios utilizados para que a função psicológica da memória se realize faz parte da base das políticas de preservação do patrimônio cultural implementadas no Brasil, visando, em sua origem, a construção de uma identidade nacional.

Em várias situações, na busca pela construção de qualidade, de uma integridade patrimonial nacional, cria-se o comprometimento de referências meramente locais. Assim, contrariando os princípios de Brandi (2005), ocorre em inúmeras situações o privilégio da instância histórica em detrimento da estética (ou o contrário), e, ainda, priorização de um determinado período histórico, nestas ações de preservação. Considerando-se as "cidades históricas", o processo é o mesmo, contudo, neste caso, no que se refere às referências nacionais mais antigas, priorizou-se a instância estética.

Exemplificaremos este processo através da trajetória das políticas de preservação em Serro (MG) a partir do início do século $X X$, quando de seu tombamento pelo Instituto do Patrimônio Histórico e Artístico Nacional (IPHAN), em 1938. Em 1817, para Saint-Hilaire (1975) "Vila do Príncipe é a capital da comarca do 
Serro Frio (...), essa vila é a mais importante da província depois de Vila Rica". Permanecendo nesta posição durante o século XVIII e XIX, Serro representou o mais significativo centro administrativo da região norte-nordeste de Minas Gerais desde a sua fundação até a República. A cidade possui uma arquitetura sem igual no território mineiro, representando um dos mais significativos conjuntos urbanísticos e arquitetônicos do Ciclo do Ouro.

Serro foi a primeira cidade brasileira tombada pelo IPHAN e a segunda a ser reconhecida como patrimônio nacional (após Ouro Preto). Conservada praticamente intacta até a década de 1960/1970, devido ao restrito crescimento físico territorial decorrente de dificuldades econômicas. Desde seu tombamento federal, Serro enquanto patrimônio cultural tornou-se responsabilidade nacional, tendo sua preservação como principal reconhecimento de seus valores.

Entretanto, talvez devido ao relativo isolamento territorial, conseqüente da não chegada da rede ferroviária até lá - foi implantada em Diamantina -, tenha Serro ficado sob certa irresponsabilidade do poder público quanto aos investimentos em políticas de preservação, conforme exige o seu tombamento. Contudo, "a instituição [IPHAN], em seus primeiros anos de vida, teve que redobrar os esforços para dar conta da tarefa que se propunha" (SPHAN/PRO-MEMÓRIA, 1980).

Mas esta relativa falta de atenção não proporcionou danos, acréscimos indevidos à cidade, como em Congonhas do Campo (MG), mas perdas por declínio, diminuição. Na década de 1960, o prefeito municipal de Serro solicitou ao IPHAN o "destombamento" da cidade devido ao excessivo número de exemplares 
arquitetônicos em processo de arruinamento. De acordo com o prefeito, havia "mais de duzentas casas em completa ruína e cujos proprietários não tinham condições de repará-las nos moldes primitivos". Para Lúcio Costa, chefe da Divisão de Tombamentos do IPHAN, faltava vontade por parte dos proprietários, e sugeriu que o órgão de preservação realizasse como modelo uma obra que mostrasse "ao vivo como a atualização moderna não é incompatível com a preservação das características originais" da arquitetura em questão (COSTA ${ }^{5}, 1968$, apud PESSOA, 1999).

Parece que Lúcio Costa estava enganado. Segundo o professor Hugo Segawa (2004) $)^{6}$, na década de 1970 a

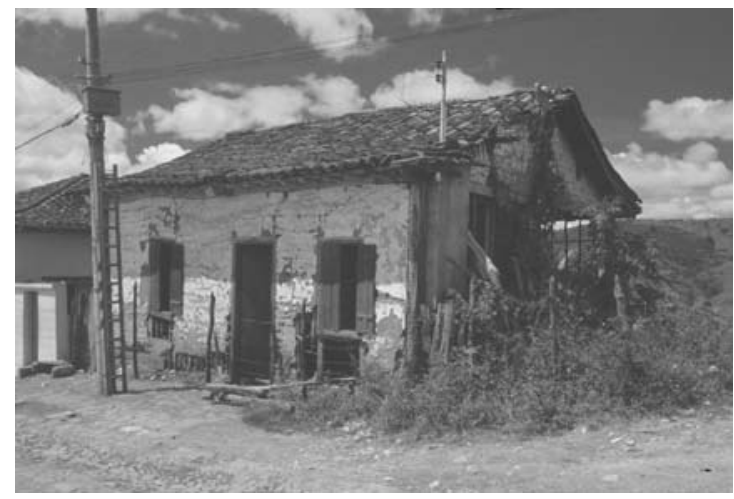

Figura 50. Casa térrea em processo arruinamento.

Fonte: Segawa (2004) - foto de 197?

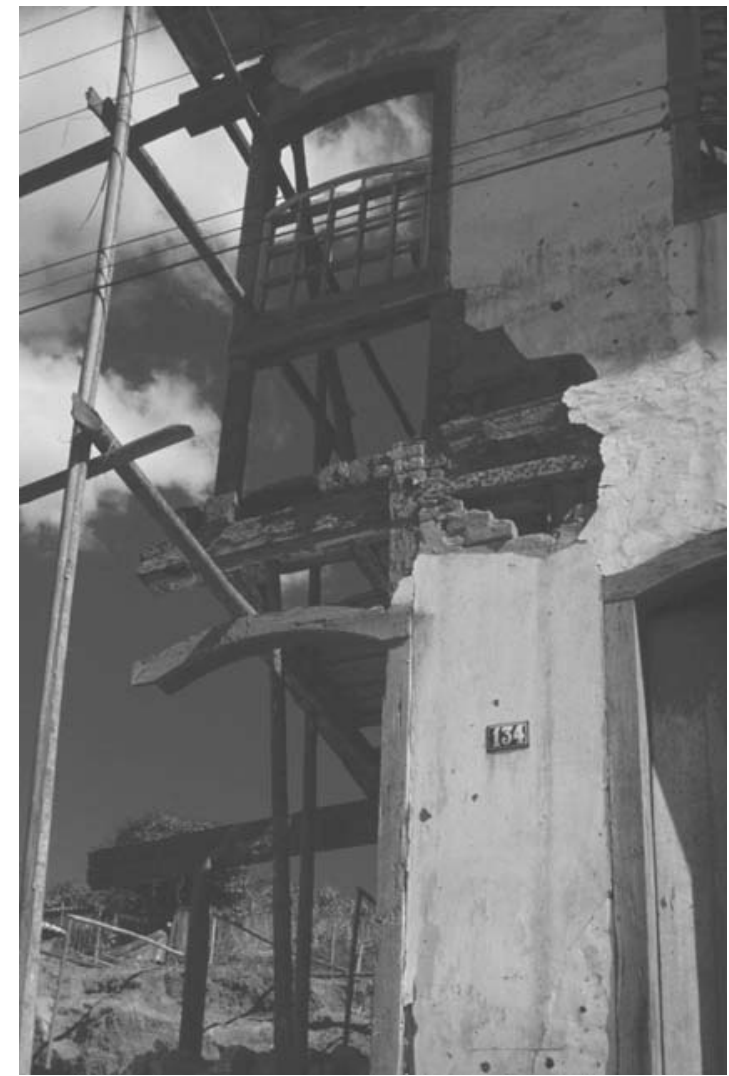

Figura 51. Sobrado em processo arruinamento.

Fonte: Segawa (2004) - foto de 197?

${ }^{5}$ COSTA, Lúcio. (1968). Pedido de revisão do tombamento do Conjunto Urbano da cidade de Serro - MG. Rio de Janeiro: Arquivo Noronha Santos (IPHAN). Apud PESSOA, J.S.B. (1999). Lucio Costa: documentos de trabalho. Rio de Janeiro: IPHAN.

6 Informação verbal do professor Segawa, 2004, em São Carlos, ao ministrar disciplina no curso de Pós Graduação em Arquitetura e Urbanismo. 
cidade ainda estava íntegra, mas com seus sobrados em ampla deterioração (Figura 50 e Figura 51), confirmando a situação apresentada pelo prefeito na década anterior. Para o professor Segawa (2004), Serro se mostrava mais encantadora que Diamantina (confirmando sua categoria construtiva de capital de comarca), e hoje não a vê mais nesta ordem. Por quê?

Diferentemente de cidades como Ouro Preto, Tiradentes, dentre outras, Serro não teve, em uma possível desconsideração de sua história local, o afastamento da população original da área tradicionalmente ocupada, mas vive ainda um processo de falta de conhecimento adequado e responsabilidade sobre ela, o que compromete a sua preservação. Para mostrar esta trajetória, podemos acompanhar o destino de um de seus espaços urbanos mais significativos, o largo da Cavalhada (atual praça João Pinheiro), configuração original típica do urbanismo de origem portuguesa nas Américas.

Segundo Robert Smith (1969), os descobridores do Brasil, embora fossem do Renascimento, como urbanistas "pertenciam à Idade Média". Entretanto, Roberta Marx Delson (1997) desenvolveu estudo detalhado demonstrando a presença planejadora do urbanismo português perpassando por cidades projetadas com traçados ortogonais, como Mariana e outras construídas a partir de orientações ajustadas aos princípios tradicionais da arquitetura vernacular portuguesa.

A cidade portuguesa constrói-se sempre de acordo com um plano, ou uma idéia de ordenamento pré-definido, mas tendo em consideração as particularidades do sítio e explorando-as quer no que se refere ao ordenamento do traçado quer à localização dos principais edifícios e funções urbanas (TEIXEIRA, 2000, p.2). 
Percebemos, de acordo com Teixeira, que o "medievalismo português" no Brasil não significa ocupação espontânea, sem princípios ou normas. Não se trata de regras rígidas, como as Leis das Índias, adotadas nas colônias espanholas, nem de desconsideração ou desleixo, mas ocorre, sim, uma organização urbana portuguesa no Brasil.

A trama urbana registrada no traçado das áreas centrais de Salvador e Rio de Janeiro, "cidades reais", repete-se no Arraial do Tejuco [Figura 52], onde o processo ocorreu de forma espontânea, o que mostra que o traçado urbano em forma geométrica não é uma decorrência de um ordenamento, tal como ocorreu na América hispânica (MOURÃO, 2001, p.8).

Existe um padrão de ocupação recorrente nas cidades portuguesas do Brasil. E, diferente do que se acreditava, o urbanismo português presente no Brasil possui princípios, conforme demonstra pesquisa de vários autores. Ainda sobre essa temática, Morris (1985) nos esclarece que as cidades que possuem referências no urbanismo

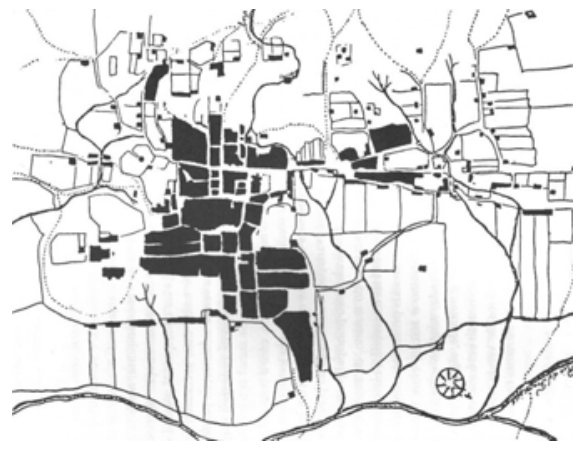

Figura 52. Mapa do Arraial do Tejuco século XVIII.

Fonte: Santos (1978)

orgânico não carecem de ordenamento ou

planejamento.

Los portugueses fueron mucho menos metódicos que los españoles en la fundación de sus asentamientos coloniales americanos, y no desarrollaron un conjunto coherente de reglas de planeamiento urbano comparable a las leyes de Indias. [...] No obstante afirmar que las ciudades coloniales brasileñas no estuvieron sometidas a ningún tipo de control en su creación y posterior desarrollo, seria negar la necesidad de algún sistema de distribución inicial de la tierra y de la acción comunitaria posterior respecto a la construcción de sistemas defensivos y a la creación de un núcleo urbano. (MORRIS, 1985, p.385). 
Portanto, mesmo nas situações onde o rigor não ocorreu, é necessário ficar atento às orientações mínimas, ou lógicas de organização urbana. Várias povoações das áreas mineradoras, apesar de em muitos casos se tornarem definitivas, a princípio, se formavam sem a pretensão de serem permanentes; buscava-se apenas a exploração e garimpagem da área, e a partir daí, partia-se em aventura para outra região. O que pode ter possibilitado a consolidação de núcleos não orientados adequadamente conforme princípios de urbanização portuguesa, mas que, posteriormente, passaram por adaptações e alterações.

Em várias situações, quando o povoado se firmava, ocorria a busca e implementação das normas então vigentes. Seja como for, quando da descoberta do ouro, houve uma ação imediata da Coroa Portuguesa, apesar de deficiente, conforme verificamos através do trabalho de Sylvio de Vasconcellos (1983), ela buscava controlar o crescimento urbano. Nesse sentido, houve uma orientação quanto ao local de fixação das povoações, sempre próximo a rios e fontes de boa água e a pouca distância ou, mesmo, junto às minas de ouro. No início, as ordens régias não tinham orientações de referência a traçados urbanos, o que indica que a intenção, no começo, era fixar os errantes e não criar povoados ordenados.

\footnotetext{
Assim foi que, em 1714 aproveitando a destruição de Ouro Preto por um incêndio, a Câmara local determinou que, no futuro, as casas das ruas que descessem na praça principal seriam mediadas e alinhadas, a fim de criar uma vista do conjunto mais regular na parte central da via (DELSON, 1997, p.29).
}

Havia duas formas básicas de atuação da Metrópole diante da política urbanizadora para o povoamento do Brasil: uma mais simples, para as vilas das capitanias, e outra com padrões técnicos elevados e mais elaborados, focando as 
cidades que eram fundadas diretamente pela Coroa. De acordo com Reis Filho (2000), no final do século XVII e no início do século XVIII, instalaram-se no Brasil várias "Aulas de Arquitetura Militar", para formar equipe de técnicos, com o objetivo de dar garantia em níveis adequados de qualidade para as obras urbanísticas e para as construções militares, de defesa de vilas e cidades brasileiras.

$E$, neste desenvolvimento de novas posturas frente ao crescimento da colônia portuguesa do Brasil, em 1695 a primeira lei agrária foi formalmente elaborada e, segundo Delson (1997, p. 12),

[...] não foi por acaso que ocorreu na mesma década de descobrimento de ouro em Minas Gerais. Esta lei limitava a concessão de sesmarias a uma extensão de quatro léguas de comprimento e uma légua de largura, visava a atingir não só as zonas de mineração, mas as áreas de terras agricultáveis.

Com base nesses fatos, a Coroa reservava-se um direito de via de penetração ou domínio público potencial, no caso de uma ocupação total da terra, garantido acesso às futuras áreas auríferas ainda não descobertas.

Contudo, apesar de estarmos focando o universo mineiro, especificamente Serro, cabe ainda conhecermos a importância que a vila de Santa Cruz do Aracaty teve para a consolidação e ampliação dos princípios urbanizadores portugueses, pois estes tiveram desdobramentos na urbanização mineira. Em 1747, o projeto para a fundação da Vila de Aracaty chegou ao Brasil. Constava de orientação e escolha de um lugar para a implantação da vila topograficamente acima das enxurradas do rio Jaguaribe, mas acessível a barcos de fins comerciais. As bases do traçado da vila obedeciam a diretrizes de retilineidade e, além disso, 
[...] recomendavam que as novas casas da vila fossem construídas com a aparência uniforme; entretanto, no caso de a nova vila ser localizada junto à povoação que já existe [...] quando um morador de casa (antiga) tiver de reconstruí-la por motivo de ruína, deve-se avisá-lo de que a casa deverá ser reconstruída de forma a dar-lhe um contorno e aparência equivalente aos das novas casas" (DELSON, 1997, p.24).

O interior da colônia aderiu a este plano por todo o século XVIII, e os administradores o implantaram neste processo de urbanização territorial, ou seja, esse modelo foi padronizado por Portugal para o traçado das novas vilas, e adaptação das existentes no interior de todo o Brasil.

Entretanto, sem dúvida, a implantação de novos padrões urbanos nas regiões de mineração foi um dos maiores desafios da Coroa portuguesa na colonização do Brasil. Desde o descobrimento do ouro, os bandeirantes e outros mineradores já haviam formado comunidades a partir de distritos de mineração construídos, sem regulamentação urbanística oficial. Foi deslocado para a região das Minas amplo aparato burocrático, encarregado de fiscalizar as atividades mineradoras em desenvolvimento. Decorrentes da circulação de riquezas, comércio e serviços que se desenvolveram, permitindo a presença de artífices, artesãos, mestres pedreiros, escultores, marceneiros, alfaiates, desde que suas atividades não se caracterizassem como industrial.

A realidade das povoações do interior do Brasil resultou em sua maioria em cidades a beira-rio, em encostas voltadas para rios, riachos ou ribeirões, predominando à meia encosta, deixando livres os terrenos mais próximos do curso de águas, apesar de no Serro a ocupação beira-rio ter acontecido de maneira 
pioneira e de pouca densidade, talvez pela não-intenção de sua permanência. Com a implantação geralmente condicionada a permitir a abertura de poços artesianos, criação de chafarizes para abastecimento de água dentro do aglomerado urbano. Entretanto, de acordo com Saint-Hilaire (1975) em sua visita de 1817 ao Serro, "não existe em Vila do Príncipe um único chafariz, e os habitantes são obrigados a ir buscar água de que necessitam no vale".

Em Serro, a implantação definitiva do povoado se deu na encosta, tendo o córrego Quatro Vinténs e Ribeirão do Lucas como definidores e direcionadores do arruamento, ou seja, as ruas acompanham as curvas de nível tornando-se praticamente paralelas a um desses principais cursos d'água. As vias transversais são curtas e se caracterizam como becos (Figura 53).

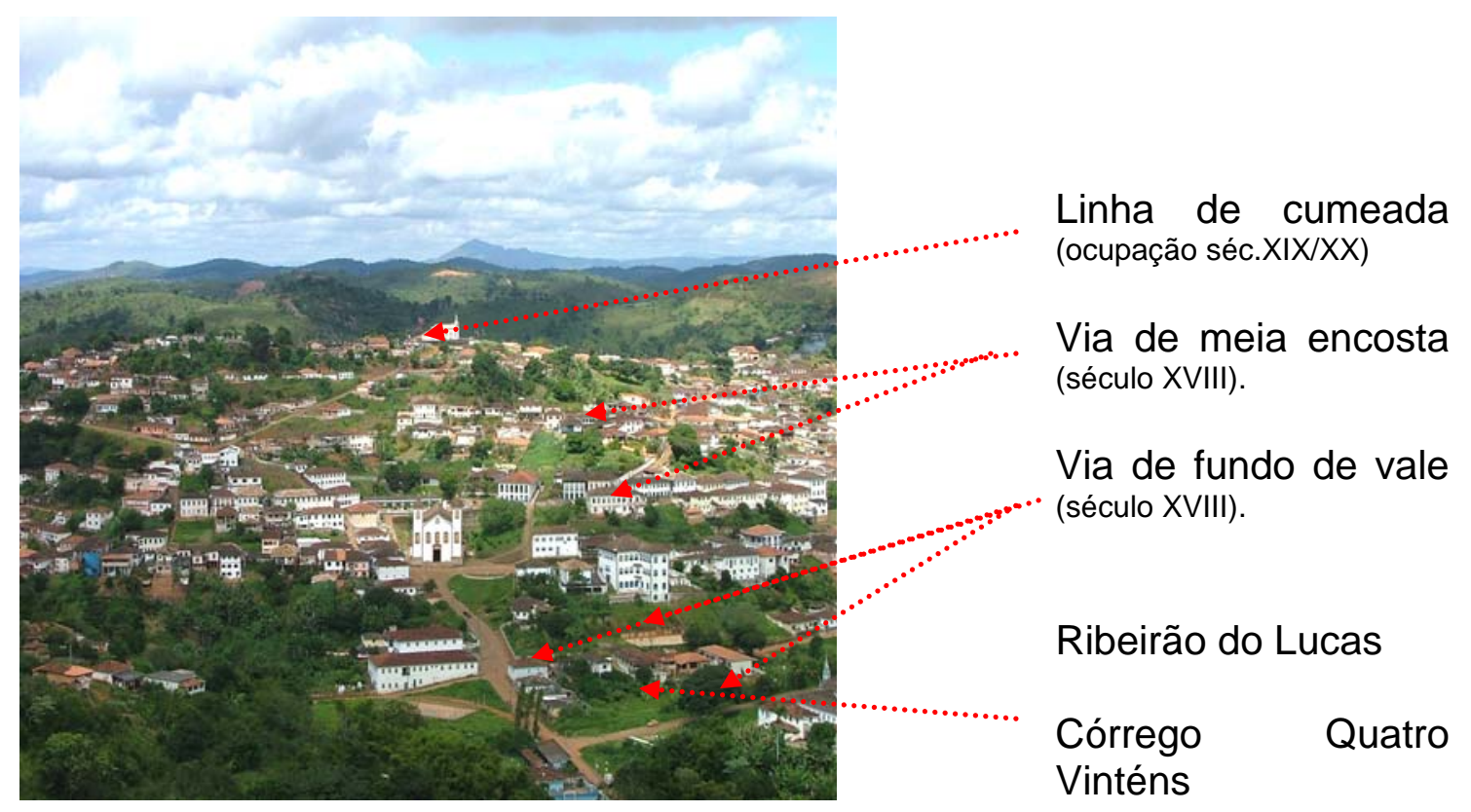

Figura 53. Ocupação urbana de Serro 


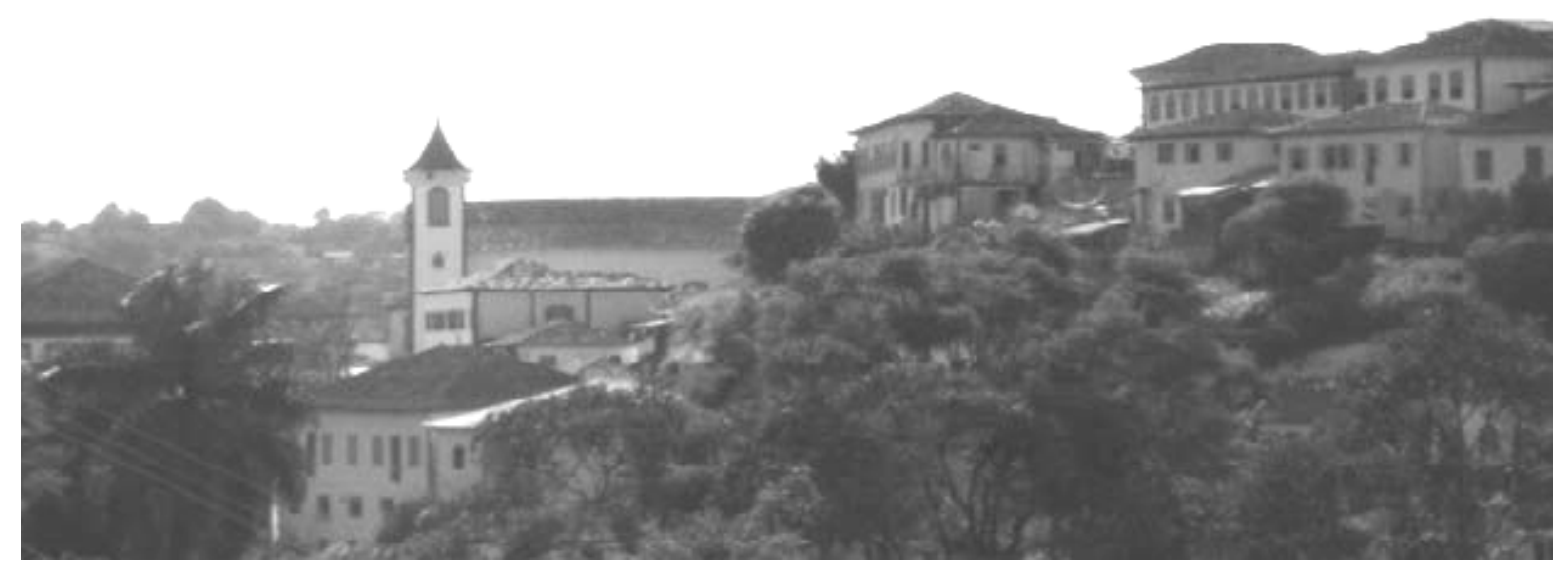

Figura 54. Perfil topográfico da ocupação urbana de Serro.

[...] das janelas que se abrem para o campo goza-se de agradável panorama: avistam-se as casas próximas entremeadas de massa espessas de verdura formada pelo arvoredo dos jardins [quintais]; mas além descortina-se o vale estreito que se estende ao pé da cidade em cujo fundo corre o Quatro Vinténs (SAINT-HILAIRE, 1975, p.145).

Ao observarmos as Figuras 53, 54, 57, 58, e analisarmos as palavras de Saint-Hilaire, percebemos que, nestes últimos quase duzentos anos, Serro ainda mantém muito de suas características originais. Será que a cidade está preservada?

Serro se mostra como um diferente centro urbano em Minas, não só por não possuir chafarizes, o que não ocorre em nenhum núcleo de importância como este do mesmo período em Minas Gerais, mas por ter sua arquitetura caracterizada predominantemente por elevada escala volumétrica, onde sobrados de dois pavimentos, devido à alta declividade, possuem até quatro pavimentos na fachada posterior (alguns trechos em Ouro Preto também possuem essa característica, mas não na proporção de Serro, pois lá são mais estreitos) e, em especial, a expressiva 
verticalidade de seus monumentos religiosos é marcante e única no universo setecentista mineiro.

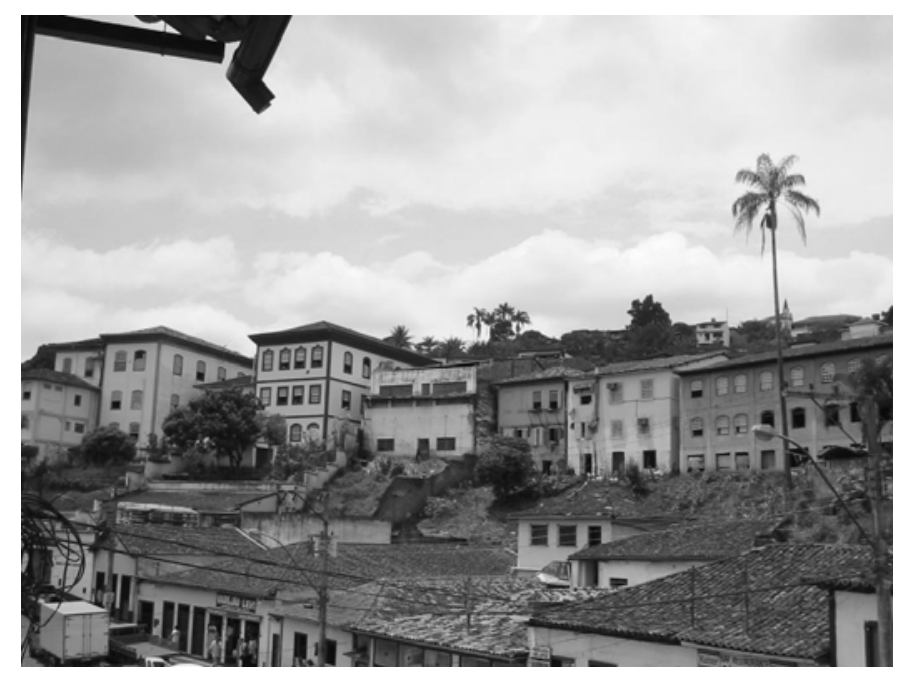

Figura 55. Fundos de edificações da rua Antônio Honório Pires e praça João Pinheiro

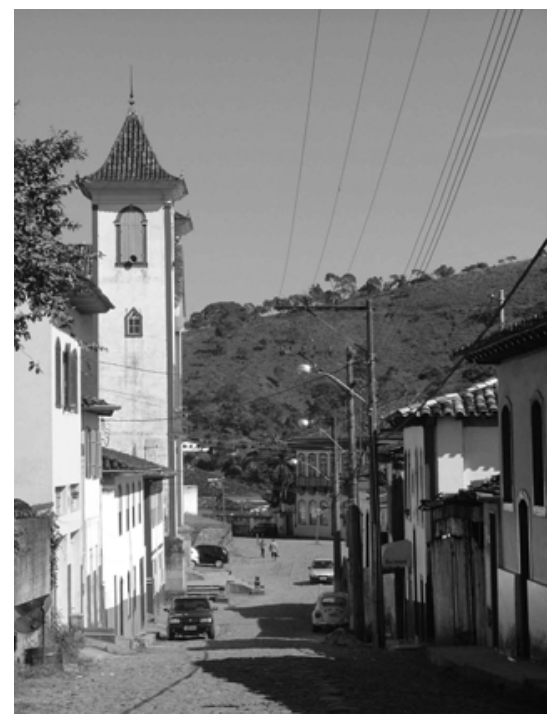

Figura 56. igreja Matriz de N.S. Conceicão

Neste rico e variado quadro, imaginamos com facilidade o importante papel desempenhado pelos espaços públicos livres (ruas, praças, largos, becos), como locais das mais importantes atividades econômicas, religiosas e sociais do século XVIII, XIX e, ainda, do XX e XXI. De acordo com Vasconcellos (1977), aquilo que inicialmente representava caminhos que ligavam pólos de ocupação de mineiros, à medida que a cidade crescia, ruas e praças tornavam locais de permanência e discussão, principalmente os largos das igrejas, onde as suspeitas de conspiração eram menores aos olhos da Coroa Portuguesa. A partir de então, consolidaram-se os arraiais e vilas, constituídas em fileiras construídas sobre os limites laterais dos 
terrenos, formando superfícies contínuas, acompanhando as curvas de níveis, em aspecto de cenário.

Essa vila [Vila do Príncipe] está edificada sobre a encosta de um morro alongado; e suas casas dispostas em anfiteatro, os jardins [quintas] que entre elas se vêem, suas igrejas disseminadas formam um conjunto de aspecto muito agradável, visto das elevações próximas (SAINT-HILAIRE, 1975, p.145).

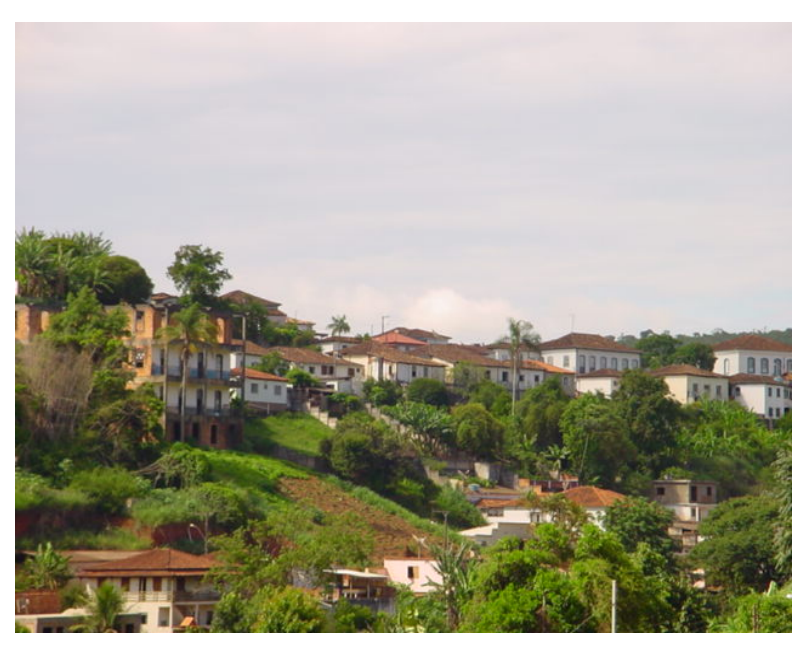

Figura 57. Vista panorâmica de Serro - Rua Fernando Vasconcelos e Rua São José

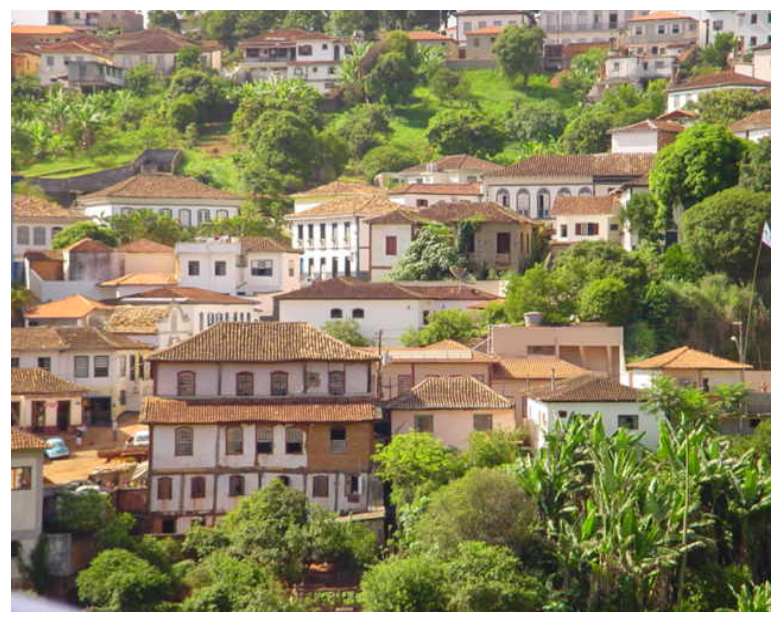

Figura 58. Vista panorâmica de Serro - praça Ângelo Miranda

Desta conformação do espaço, percebe-se que historicamente as praças estão ligadas à função desempenhada pelas igrejas, como foco da vida urbana. No caso do Serro, curiosamente as duas praças tradicionalmente mais importantes (praça do Pelourinho/praça da Matriz/praça Getúlio Vargas e o largo da Cavalhada/ Praça João Pinheiro que está defronte à praça da igreja do Carmo, representando praças contíguas) são resultado da interseção do poder religioso e civil. 


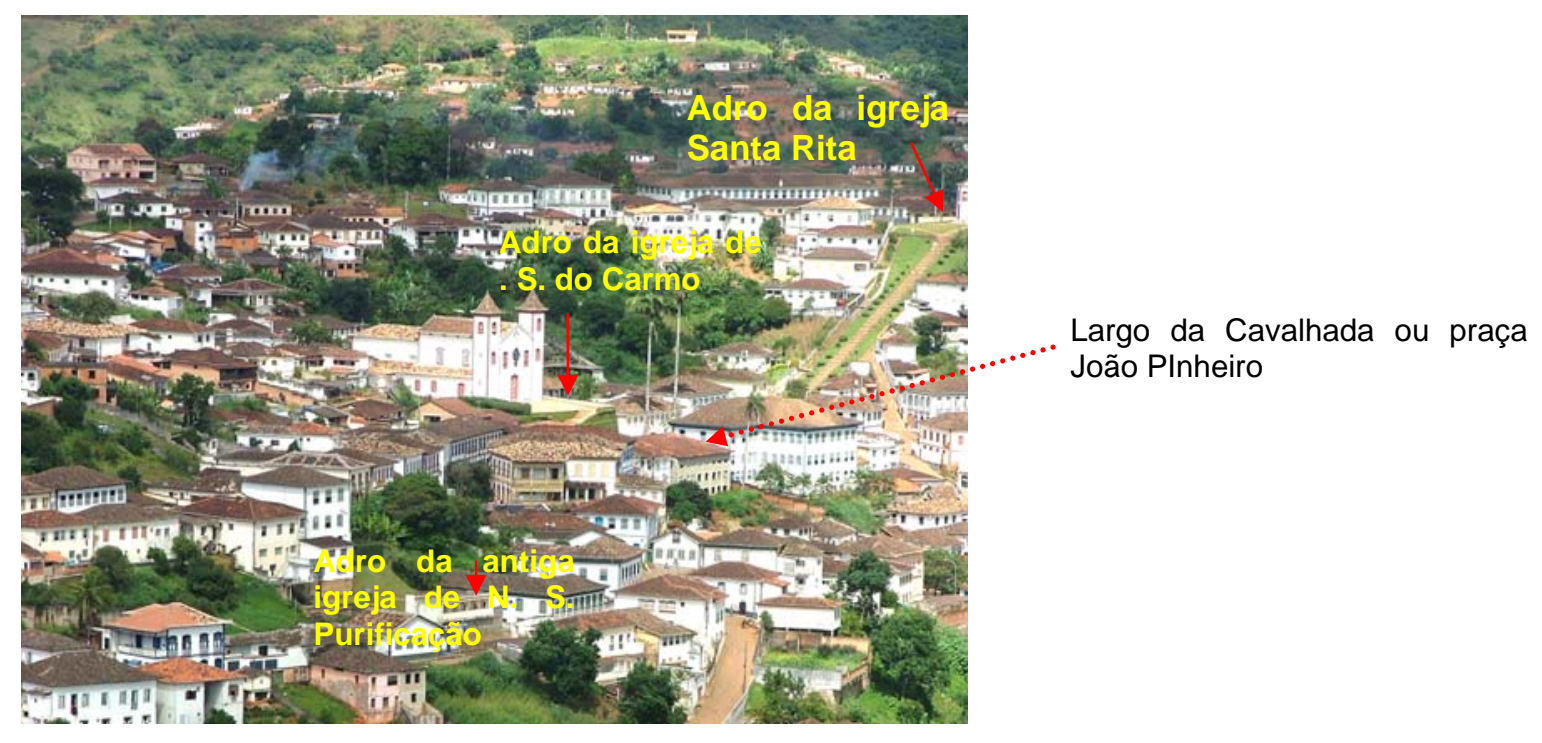

Figura 59. vista panorâmica de Serro - praça João Pinheiro

As igrejas em Serro atuam como articuladoras do espaço definindo núcleos e regiões da cidade, estando em evidência devido à localização no conjunto urbano (Figura 60). Julião (1989), a partir de estudo desenvolvido em Ouro Preto e Diamantina, aponta como os edifícios religiosos tornam-se a manifestação do pensamento, por meio de suas características arquitetônicas e urbanísticas, de grupos sociais diversos, assim como de marcos de sua independência.

as igrejas além de colaborar na organização da sociedade local, elas também estruturavam a paisagem da cidade. É o agrupamento das igrejas que trás à cidade um significado, fazendo-a compreensível. (JULIÃO, 1989, p.8, tradução da autora). 


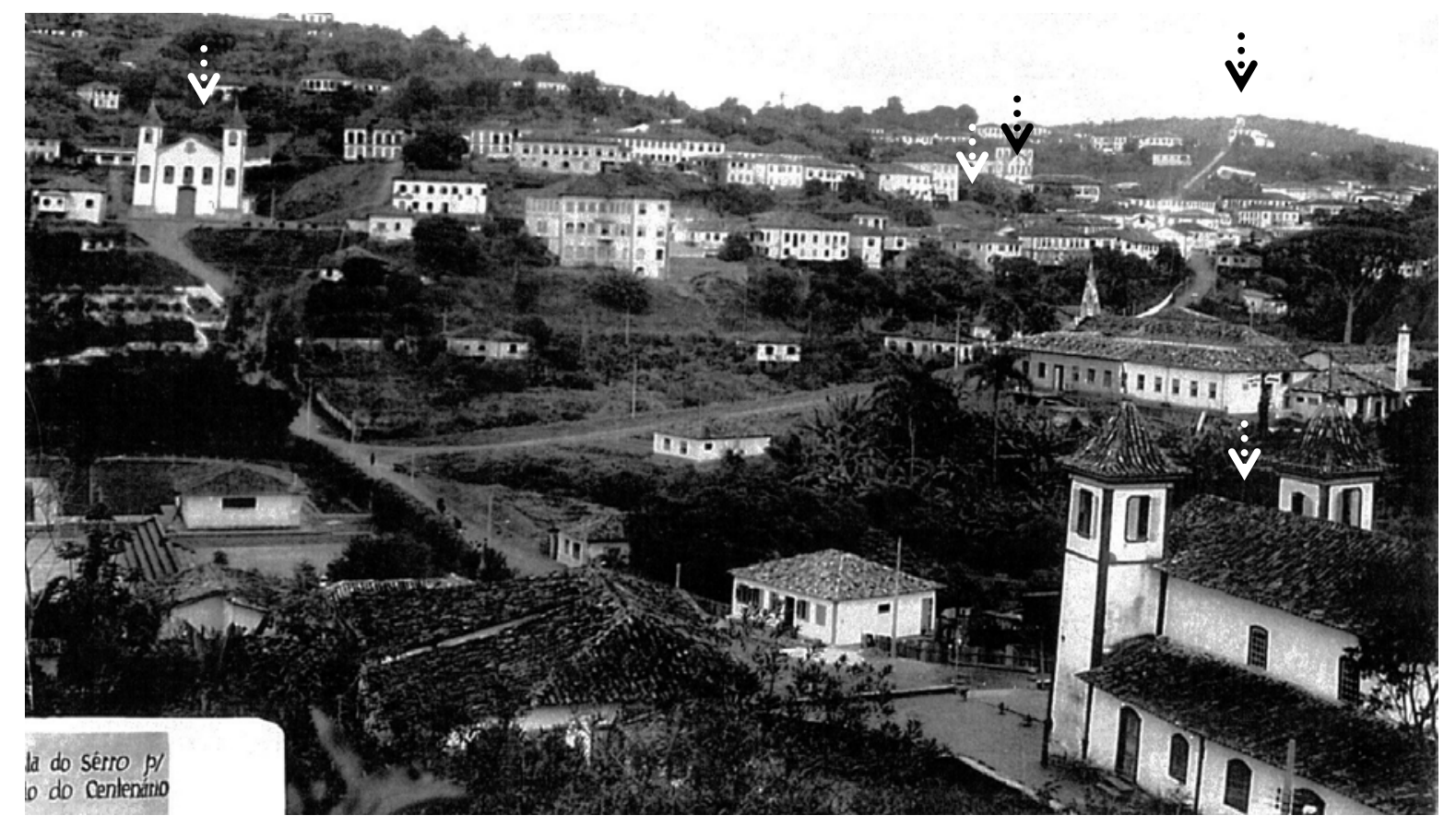

Figura 60. Vista panorâmica de Serro. Articulação entre as igrejas setecentistas (Bom Jesus do Matosinho/N.S.Conceição/N.S. Purificação(demolida)/N.S. Carmo/Santa Rita Fonte: EA UFMG (2006) - LAFODOC

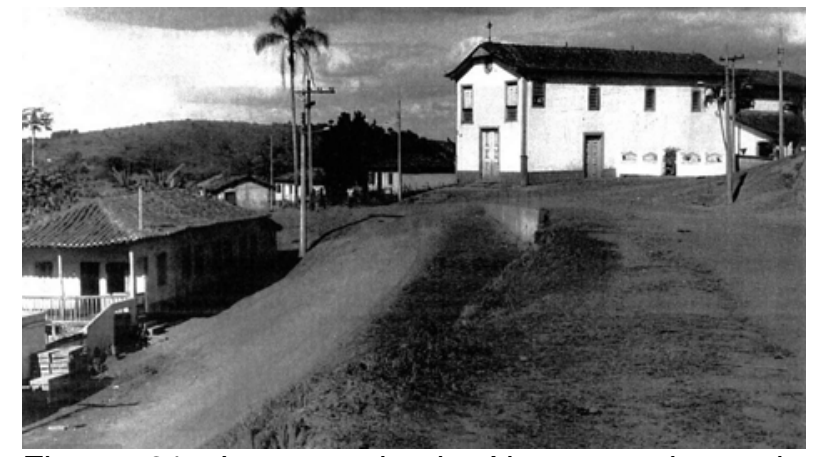

Figura 61. Largo e igreja Nossa senhora do Rosário

Fonte: EA UFMG (2006) - LAFODOC

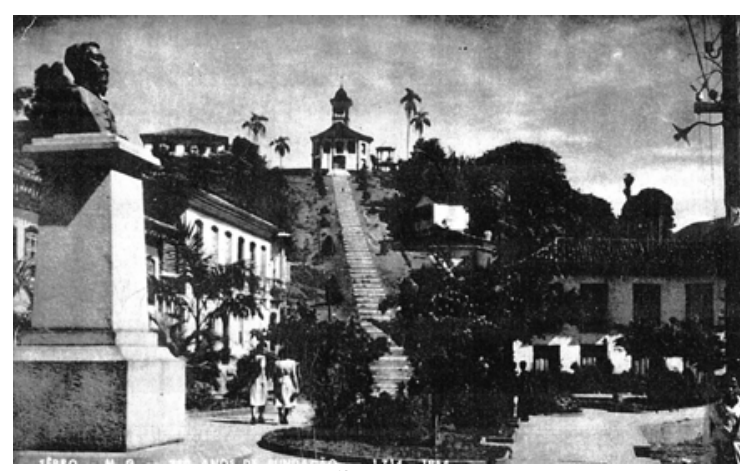

Figura 62. Praça João Pinheiro - escadaria da igreja Santa Rita

Fonte: EA UFMG (2006) - LAFODOC 
Neste sentido, entendemos que a atual praça João Pinheiro, antigo largo da Cavalhada, apesar de estar ao sopé da igreja de Nossa Senhora do Carmo, e receber a prefeitura, quando de sua conformação não tinha como principais condicionantes nem a igreja e nem palácios administrativos.

Esta praça foi concebida para o lazer da comunidade, treinamentos a cavalo das milícias (pois no século XVIII representava o extremo oeste da cidade, seu limite). Além de representar o ponto de confluência entre os fiéis que se dirigiam para a praça da igreja do Carmo, e adro da igreja Santa Rita, podemos considerá-la como conexão destas áreas religiosas com o adro da Igreja Franciscana de Nossa Senhora da Purificação (demolida na década de 1930). Entendemos que essa configuração e tipologia sejam únicas dentre os espaços setecentistas mineiros.

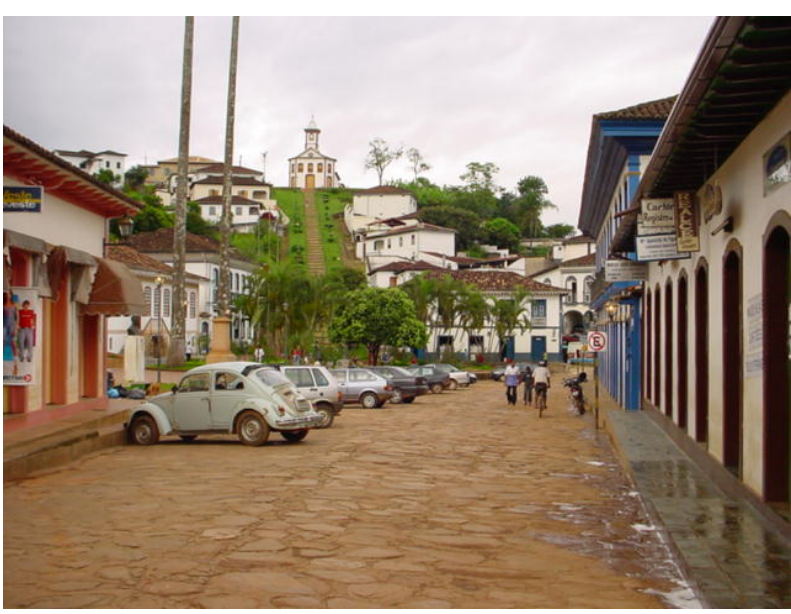

Figura 63. Praça João Pinheiro

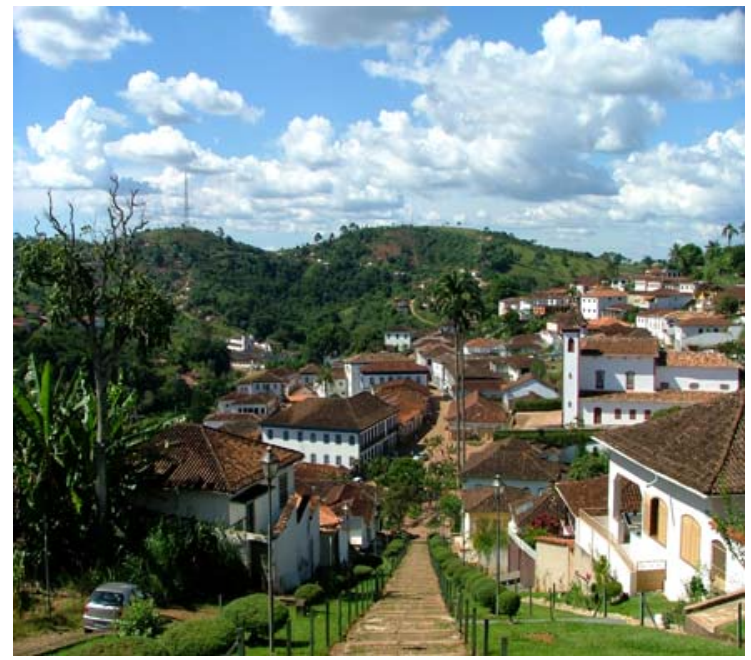

Figura 64. Praça João Pinheiro - vista a partir do Largo da Ig. Santa Rita 


\section{A cidade para ser preservada}

No Brasil, país jovem, a ideologia do novo, onde a paisagem construída é constantemente modificada, é curioso a conservação de um conjunto urbano setecentista como o Serro. A cidade é caracterizada pela disposição em vários níveis numa topografia íngreme, carrega as marcas de sua história - riqueza inicial, um período de grande desenvolvimento, mais de um século de poder administrativo, grande prestígio político, seguidos de gradual declínio, empobrecimento e perda de sua posição favorável diante da sociedade. Por influência de seus percalços econômicos e pela perda de sua importância administrativa no norte e nordeste de Minas, Serro manteve-se conservada, quase intacta durante quase todo o século $X X$.

Serro foi "redescoberta", a partir da década de 1920, pelos intelectuais do movimento modernista brasileiro, em suas viagens pelo Brasil na busca do reconhecimento da "verdadeira identidade nacional". E é nesse período, na comemoração do centenário da Independência do Brasil que neocoloniais e modernistas se expressaram na busca pela preservação do patrimônio brasileiro, com o envolvimento do Estado. Nessa época, o Museu Nacional trabalhava solidamente na preservação de objetos de valor histórico e artístico, entretanto "multiplicavam-se na imprensa denúncias sobre o abandono das cidades históricas e a destruição irremediável dos tesouros da nação" (CASTRIOTA, 2003). 
Tendo em vista tais pressões e a existência de um trabalho em andamento para a preservação de bens culturais nacionais, foi criado pelo governo federal o SPHAN - Serviço do Patrimônio Histórico e Artístico Nacional, o atual IPHAN. Organizado pelos intelectuais de vanguarda, diferentemente do resto do mundo, no Brasil, foram os modernistas que elaboraram e implementaram as políticas de preservação do patrimônio cultural. De acordo com Amaral (1995), os escritores brasileiros que participaram do Movimento Moderno, que teve início na Semana de Arte Moderna de São Paulo, gradualmente perceberam que a realidade brasileira era importante tanto quanto a renovação formal da arte.

Neste quadro em 1938, foi instruído o processo de tombamento de Serro, com Lúcio Costa à frente da Divisão de Tombamentos do IPHAN, sendo a primeira cidade inscrita no Livro do Tombo de Belas Artes pelo recém-criado serviço de patrimônio nacional (naquela época o tombamento envolvia todo o núcleo urbano). A característica eminentemente rural de Serro, tendo toda sua trajetória urbana tradicional vinculada ao ciclo do ouro à economia agropecuária e à existência de uma arquitetura de grandes sobrados com amplos beirais, com afastamentos entre uma edificação e outra (não há o predomínio do aproveitamento de "parede e meia"), é revalorizada pelos modernistas, que vêem como uma síntese cultural própria, esboçada por uma sociedade no interior do Brasil, que se mostrava conectada às diversas influências culturais que recebeu, mas de maneira autêntica

Entendemos que essa leitura de um passado nacional, no que se refere à arquitetura, desempenhou um papel de destaque na formulação de uma política de preservação, assim como princípios para a própria arquitetura moderna, conforme 
apresentou Lúcio Costa em seu artigo "Documentação Necessária”, na revista n¹ do IPHAN. Essa postura que concilia o novo com a revalorização da tradição é visivelmente transmitida por Lúcio, que ressaltava como traços básicos e comuns à arquitetura dos dois períodos, a simplicidade, austeridade, pureza, bom uso dos materiais; fez inclusive analogia entre o pau-a-pique e o concreto armado, em sua forma de estruturação.

Considerando-se esta visibilidade atribuída às artes do passado brasileiro, para a construção de uma nova arquitetura, impôs-se a questão da preservação desse importante acervo representado pelas cidades e arquitetura do período colonial, que se tornou indispensável ao processo de construção da identidade nacional. Em 1937, é instituído o instrumento central da legislação brasileira de preservação - o "tombamento" - que, conforme já dissemos, teve aplicação automática no Serro. Com tal instrumento, o IPHAN pôde de imediato intervir em bens culturais, restaurando monumentos, prevenindo danos, impedindo demolições dos bens que tombava, além de controlar a introdução de novas edificações nos sítios urbanos protegidos, ou entorno de bens tombados individualmente.

Acreditamos que a preservação do patrimônio cultural no Brasil se iniciou de maneira atualizada, uma vez que a cidade reconhecida como patrimônio em termos mundiais tinha acontecido havia aproximadamente 30(trinta) anos. E nesse momento estava em plena discussão por estudiosos como Gustavo Giovannoni.

Essas malhas antigas ganham dois novos privilégios: elas são, da mesma forma que os monumentos históricos, portadoras de valores artísticos e históricos, bem como de valor pedagógico e de estímulo [...] [por esta individualidade] que foi possível integrá-las numa 
doutrina sofisticada da conservação do patrimônio urbano. (CHOAY, 2001, p.198).

A cidade passa a ser percebida como "organismo estético" e historiográfico sem se ignorar seu processo de mutação pela era industrial. Segundo Giovannoni (1925) "uma cidade histórica constitui em si um monumento", mas sem deixar de estar em constante transformação. Desta maneira, entendemos que a ação de proteção implementada pelo IPHAN a partir da década de 1930 se mostrou contemporânea e atual perante o que acontecia do mundo quanto a esse tema (estamos falando da ação legal de proteção - e não da ação técnica de conservação urbana).

De acordo com Castriota (2003, p.193), "as primeiras ações do IPHAN derivam diretamente daquela narrativa ortodoxa da história [...], que estabelecia uma espécie de afinidade eletiva entre nosso passado barroco e colonial e a arquitetura moderna que então fazia". Nesse sentido, é curioso observamos o indicativo de que esta política nacional de preservação, num primeiro momento, tenha entendido que a arquitetura brasileira havia se iniciado com o Ciclo do Ouro em Minas Gerais. Disto percebemos que, para os intelectuais da preservação, a arquitetura de relevância tratava apenas da barroca e, contemporaneamente, da modernista. Essa leitura nos é indicada a partir da identificação dos tombamentos realizados nos primeiros tempos do IPHAN.

Analisando por que todas as cidades tombadas pelo IPHAN, de 1938 a 1943, foram inscritas no Livro do Tombo de Belas Artes, percebemos o reconhecimento, pelo instituto de preservação, do "valor artístico" como valor decisivo para a 
preservação do conjunto urbano, que é então visto sob o ponto de vista estético. Essa postura se aproxima da leitura formal da cidade realizada por Camillo Sitte? Da obra de arte por Cesare Brandi?

Analisando o valor predominantemente estético atribuído às cidades setecentitas mineiras, percebemos que os tombamentos urbanísticos realizados pelo IPHAN em Minas Gerais (de todas as épocas) desde sua origem estão distribuídos nos livros do Tombo, conforme gráfico "Incidência de inscrição de sítio urbano cidade por Livro do Tombo em MG".

A partir da Figura 65, verificamos que o "valor artístico" atribuído aos sítios urbanos quando de sua inscrição no Livro do Tombo, representa um indicativo das posturas conceituais adotadas pelo Estado brasileiro, guiadas por uma "leitura técnica" de valor cultural atribuído, ou percebido na obra, visando neste caso a preservação

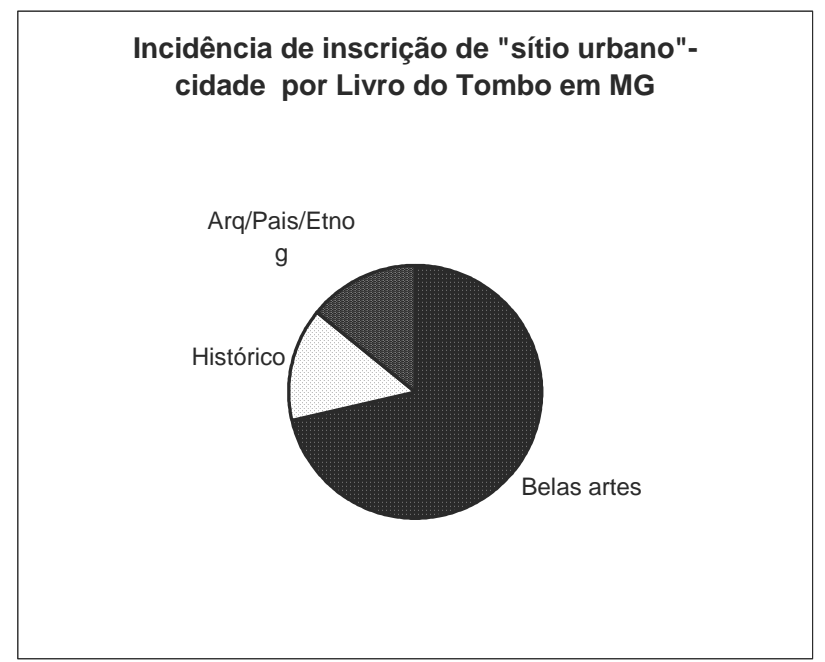

Figura 65. Livros do Tombo com inscrição de patrimônio urbano mineiro (pode haver um mesmo bem inscrito em mais de um Livro). Fonte: adaptado de www.iphan.gov.br

da área urbana identificada, ou reconhecida.

Portanto, verifica-se que no universo mineiro, os "sítios urbanos" protegidos por lei federal, que originalmente representavam os limites da cidade, foram todos 
inscritos no Livro do Tombo de Belas Artes, e apenas Ouro Preto teve sua inscrição ampliada, passando a constar do Livro do Tombo Histórico; e no Livro do Tombo Arqueológico, Etnográfico e Paisagístico, em 1986 (48 anos após sua inscrição no Livro de Belas Artes).

Percebemos que oficialmente ocorre uma consideração estética privilegiada para a cidade tombada em Minas Gerais, e que seu valor documental, sua trajetória urbana e seus diversos componentes de expressão cultural, é resultado de um conjunto construído socialmente que a destaca como arte. Disso, importa ainda que a estruturação do Decreto Lei 25 permiti legalmente a ampliação deste reconhecimento através da inscrição no Livro do Tombo Histórico e Arquitetônico, Paisagístico e Etnográfico.

Esse reconhecimento pelo IPHAN do valor estético atribuído às artes (plásticas, aplicadas, arquitetura e urbanismo) de origem colonial mineira, o "Barroco Mineiro", possibilitou inicialmente perdas ou desfiguração daquelas artes que não pertenciam a esse período, conforme aconteceu com a arquitetura em Ouro Preto, por exemplo, de acordo com pesquisa de Lia Motta (1987). Contudo, acreditamos que tal postura, naquele momento, pudesse estar adequada a seu tempo. As ações ocorreram como parte de um processo de construção do fazer por que se acreditava que aquela era a melhor maneira de se preservar "o antigo", "o original", o "verdadeiramente brasileiro". Neste sentido, cabe lembrar que de acordo com Andrade (1993), Lúcio Costa e por, conseqüência, o IPHAN tiveram influência de Viollet-le-Duc. 
Entretanto, essa ação de valorização da arquitetura barroca em relação às demais não se fez presente em Serro como em Ouro Preto e Tiradentes, por exemplo, talvez pelo fato de que a cidade de Serro estivesse "íntegra" conforme sua origem colonial. Como dito anteriormente, a não-implementação da ferrovia em Serro a deixou fora do circuito da "modernização" até meados do século $X X$, o que para a arquitetura, representou uma lacuna ou ausência de "vários estilos" e "atualizações".

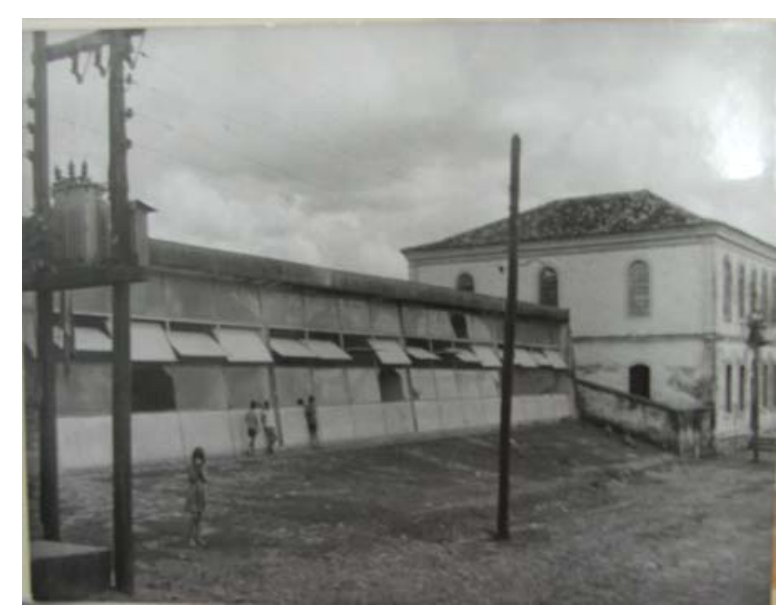

Figura 66. Grupo Escolar João Nepomuceno/Serro - Projeto de Alcides da Rocha Miranda. Fachada principal Fonte: IPHAN (2006)

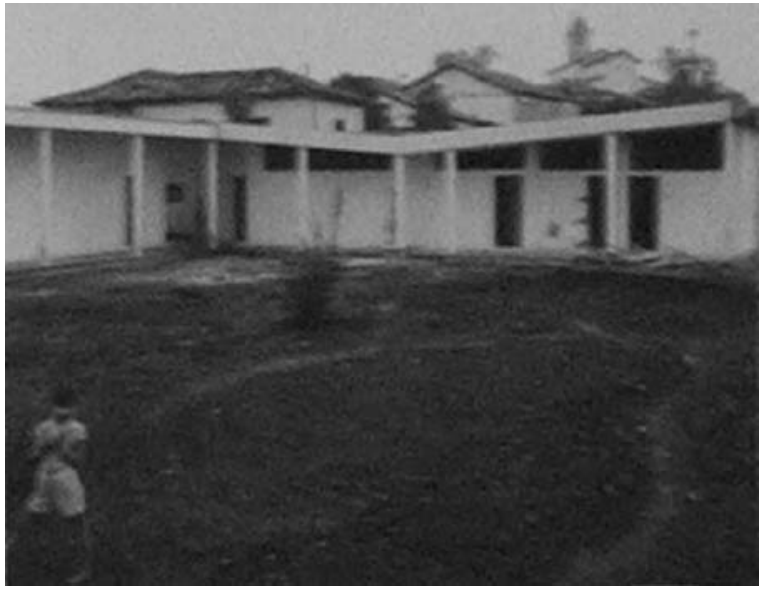

Figura 67. Grupo Escolar João Nepomuceno/Serro - Projeto de Alcides da Rocha Miranda. Pátio interno Fonte: IPHAN (2006)

A compreensão da cidade como expressão estética, no caso do Serro, exigiuIhe apenas a manutenção do existente no ato do tombamento, garantindo homogeneidade ao conjunto. Entretanto, eram admitidas construções de algumas edificações modernas, desde que "de boa qualidade arquitetônica", de acordo com a avaliação dos técnicos do IPHAN, ou realizada por eles mesmos. Como o grupo 
escolar João Nepomuceno, projeto modernista de Alcides da Rocha Miranda, realizado em Serro.

Com isso a ação de preservação em Serro nos primeiros anos se ateria à simples conservação, ou restauração preventiva (o que foi realizado em alguns momentos com deficiência tendo em vista a ocorrência do processo de arruinamento arquitetônico na cidade, a partir da década de 1960). Entretanto, o trabalho de preservação adotado pelo IPHAN era resultado de acúmulo de valores agregados decorrentes do aprendizado em todos os núcleos urbanos tombados por ele. Cada localidade trazia situações novas e pressões diversas, principalmente em Ouro Preto, Diamantina que, até o final do século $X X$, era a única cidade tombada com delimitação de perímetro de tombamento. Desta necessidade de estar respondendo as demandas de imediato

\footnotetext{
o IPHAN caminha, então, cada vez mais para o enrijecimento das normas, passando a exigir uma série de traços estilísticos nas novas edificações detalhes típicos das construções e acabamento de telhados, cornijas, bem como esquemas cromáticos bastante rígidos (CASTRIOTA, 2003, p.195).
}

Percebemos que algumas das medidas apontadas por Castriota (2003) fazem parte de uma coerência adotada pelo IPHAN, a partir do reconhecimento de que o valor estético da cidade, entendido a partir daquilo que é percebido pela mente representa de fato o reconhecimento que legitima o bem patrimonial. Se SaintHilaire, dentre outros viajantes naturalistas que percorreram estas cidades, as descreve com detalhes inclusive de cores e acabamentos, e se no ato do seu reconhecimento como patrimônio nacional assim se encontravam, é natural que se busque esta manutenção. 
Podemos avançar nossas análises, nos casos em que o IPHAN procurou a "correção" do que considerava fora dos valores estéticos tidos como primordiais, para uma possível aplicação dos princípios de Viollet-le-Duc, quanto à restituição do bem à sua condição de integridade física. Nesse caso, acreditando ser esta uma forte teoria tendo em vista a afirmação de Andrade (1993) quanto à influência de Viollet-le-Duc em Lúcio Costa, principal mentor destas ações do IPHAN, percebemos um certo "retrocesso" da postura preservacionista adotada, uma vez que o restauro científico com Gustavo Giovannoni, na Itália, já estava consolidado na década de 1930, trazendo posturas menos antigas, ou até mesmo avançadas quanto à manutenção e valorização do bem patrimonial assim reconhecido, principalmente na temática urbana.

Pela vertente italiana de preservação, a cidade passa a ser percebida como "organismo estético" sem se ignorar seu processo de mutação pela era industrial; e Giovannoni (1925), entendendo que "uma cidade histórica constitui em si um monumento", mas sem deixar de estar em constante transformação. O autor italiano fundou a doutrina da conservação e restauração do patrimônio urbano fundamentada em três princípios básicos: "o fragmento urbano antigo deve ser integrado num plano diretor local, regional e territorial", (GIOVANNONI, 1925).

Contudo, no Brasil, Lúcio Costa, à frente das grandes ações preservacionistas do IPHAN, já em 1958, em se tratando de Ouro Preto, afirma que, visando atender 
natureza diversa tais como: $1^{\circ}$. Demolição; $2^{\circ}$. Recomposição; $3^{\circ}$. Restauro; 4. Remoção ou transferência (COSTA ${ }^{\dagger}, 1958$ apud PESSOA, 1999, p.148).

Decorrente desses direcionamentos, Lúcio Costa aponta, na categoria "demolição", a remoção da arquitetura eclética que se alinhava com monumentos de origem colonial, eliminação de elementos ecléticos de fachadas de edifícios aproximando-os da arquitetura tradicional. Propõe pintura de telhados para que a cobertura seja "camuflada". No caso da categoria "restauro", propõe transferência de uso e eliminação de elementos arquitetônicos que considera inadequados à arquitetura monumental, assim como remoção de acréscimos e restituição de elementos removidos inadequadamente. Para Lucio Costa ${ }^{8}$ (1958 apud Pessoa, 1999), "o tombamento obriga a providências de caráter radical quando se trata de preservar ou repor a coisa em seu estado original". Lúcio Costa, em suas posturas preservacionistas, é influenciado por quem? Será mesmo por Viollet-le-Duc?

Com tudo isso, a trajetória de preservação adotada pelo IPHAN nos "sítios urbanos" que tombou, quanto aos acréscimos, vem seguindo de maneira predominante, desde sua origem preservacionista, o "estilo colonial" denominado por muitos como "estilo patrimônio".

\footnotetext{
${ }^{7}$ COSTA, Lúcio. (1958). Conjunto Arquitetônico e Urbanístico - Ouro Preto - MG. Rio de Janeiro: Arquivo Noronha Santos (IPHAN). Apud PESSOA, J.S.B. (1999). Lucio Costa: documentos de trabalho. Rio de Janeiro: IPHAN.

${ }^{8}$ COSTA, Lúcio. (1958). Conjunto Arquitetônico e Urbanístico - Ouro Preto - MG. Rio de Janeiro: Arquivo Noronha Santos (IPHAN). Apud PESSOA, J.S.B. (1999). Lucio Costa: documentos de trabalho. Rio de Janeiro: IPHAN.
} 


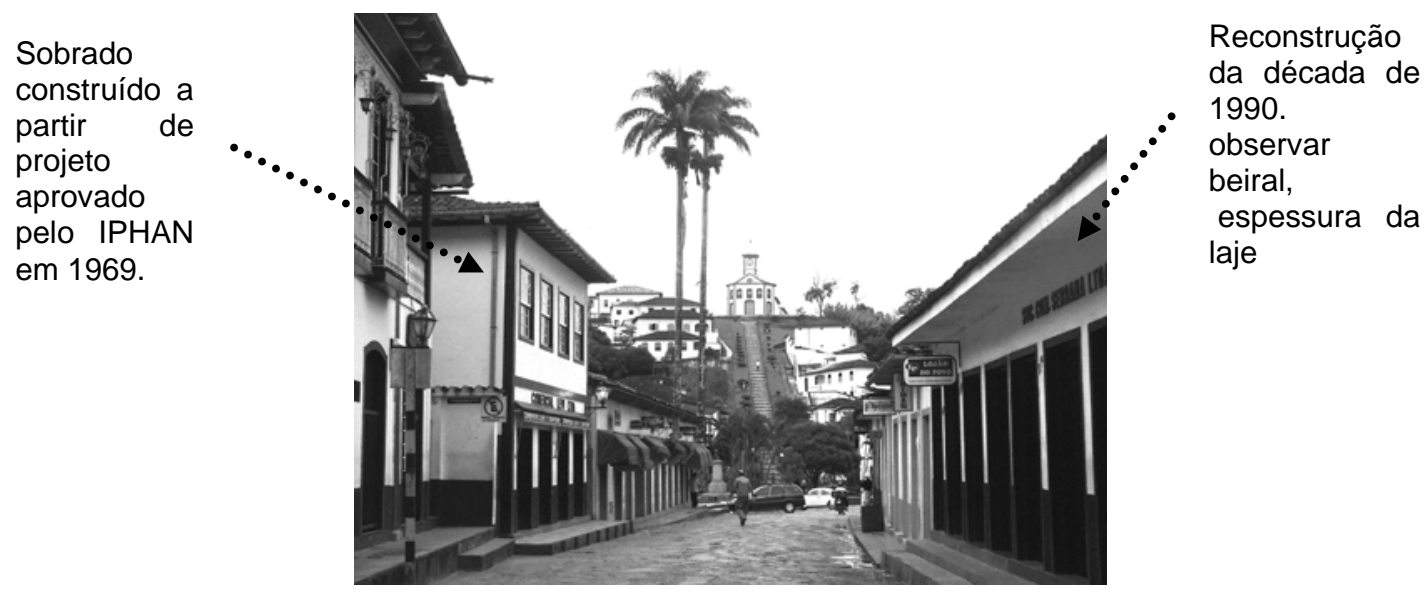

Figura 68. Rua Dr. Antônio Tolentino/Serro construções contemporâneas.

Mas, para Serro, esta ação de novas construções não foi inicialmente tão expressiva, pois o conjunto cresceu pouco até a década de 1980 . Foram poucos os projetos dessa natureza, sendo ainda possível a percepção das edificações originais, apesar de que, para os não especialistas sobre o tema, pode haver dúvidas. Acreditamos que os maiores danos estejam atrelados às intervenções da década de 1990, com o acelerado adensamento e parcelamento do solo urbano, e graves substituições de originais por reconstruções arquitetônicas, que podem colocar em dúvida a autenticidade do conjunto.

Entretanto, a arquitetura de origem colonial mineira, é marcada pela simplicidade de detalhes. Na maioria das situações, ao se observar os pormenores arquitetônicos (beiral, cunhal, vãos, plasticidade do telhado, dentre outros), percebese a "imitação". 


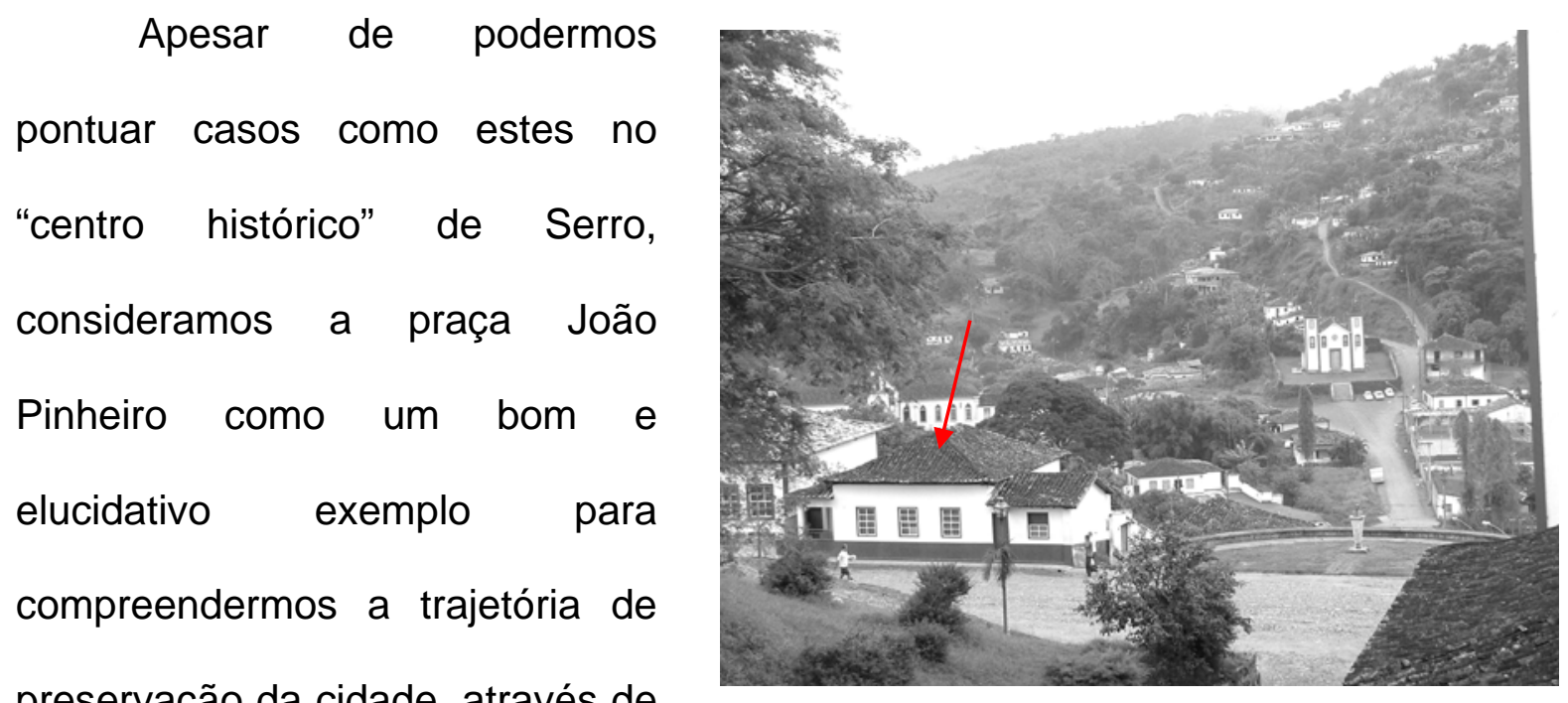

preservação da cidade, através de

suas transformações urbanísticas
Figura 69. Construção do séc XX que ocupou parte da Praça Getúlio Vargas/Praça da Matriz ou Largo do Pelourinho.

e arquitetônicas, que resulta na alteração na imagem urbana. E discutimos as modificações sofridas por esta praça que representa destacada configuração do urbanismo das cidades de origem portuguesa no Brasil.

Nestas cidades, estruturadas de maneira natural, que acompanham a geografia, a topografia no terreno, o conjunto de vias se apresenta principalmente a partir das ruas e praças, além de uma sucessão de outros tipos de espaços públicos como largos, pátios e antigos terreiros - de forma geralmente irregular freqüentemente conectados por monumentos religiosos ou administrativos - que desempenham papel de destaque na articulação urbana e social, conforme

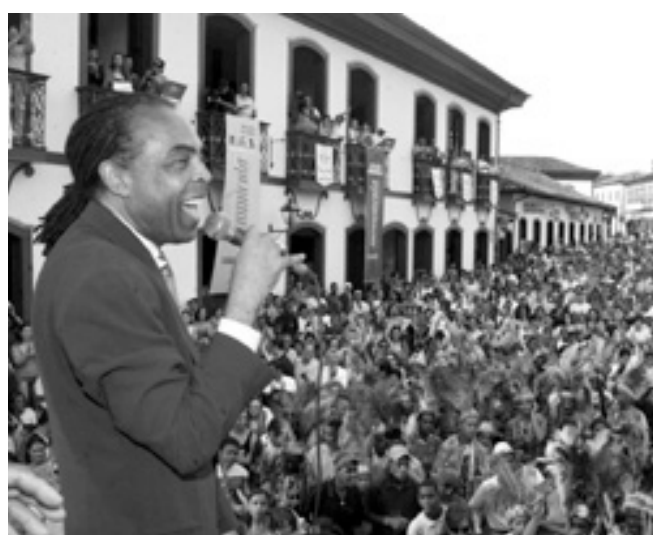

Figura 70. Praça João Pinheiro - ato público de demanda cultural - Ministro da Cultura em oficialização do Programa Monumenta em Serro. Fonte: MINC (2007) entendimentos, também, de Camillo Sitte (1992). 
Esta é a realidade do antigo largo da Cavalhada em Serro, que era um "espaço vazio" estendido à frente da destacada Igreja de Santa Rita, e servindo de platéia para a praça da igreja de Nossa Senhora do Carmo em Serro. Localizado praticamente ao lado da praça da antiga igreja de Nossa Senhora da Purificação (hoje praça Dom Epaminondas), o largo da Cavalhada, ou atual praça João Pinheiro, até o século XIX recebia a confluência das atividades da vida cotidiana, como lazer, já que o espaço oficial da cidade era a praça da Matriz. A partir do século $X X$, com a transferência da Câmara e Prefeitura Municipal para o mesmo sobrado, a praça João Pinheiro passou a representar o centro do poder oficial da cidade.

Percebemos que espaços como esse não são originalmente obras de projeto rígido; seu uso e significado não são dados de uma vez por todas. Formam a cada momento uma nova história. Assim, com o passar do tempo, a ligação entre os edifícios religiosos e oficiais que circundam este "espaço vazio", com a inserção de edificações residências e comerciais, foi se tornando especial para cada momento no transcorrer dos anos.

Ao compreendermos a origem da conformação do largo da Cavalhada, percebemos que no final do século XVIII, de acordo com Silva (1928), fieis obtiveram terreno na "rua direita da Cavalhada", para erigir uma capela, e assim, em 1781 estava sendo inaugurada a igreja de Nossa Senhora do Carmo. E, antes disso, na $1^{\mathrm{a}}$ metade do século XVIII, já existia a igreja de Santa Rita, com a implantação em cota de nível bem mais elevada que a da praça. 
A arquitetura civil da praça é predominantemente do século XIX, inclusive o sobrado da Prefeitura Municipal/Câmara Municipal do Serro, que foi construído no último quartel do século XIX, para hospedar o imperador Dom Pedro II (o que não aconteceu devido à Proclamação da República). Tornou-se residência particular até 1914, quando passou à Câmara Municipal e, posteriormente, abrigou ainda a prefeitura (FUNDAÇÃO JOÃO PINHEIRO, 1993).

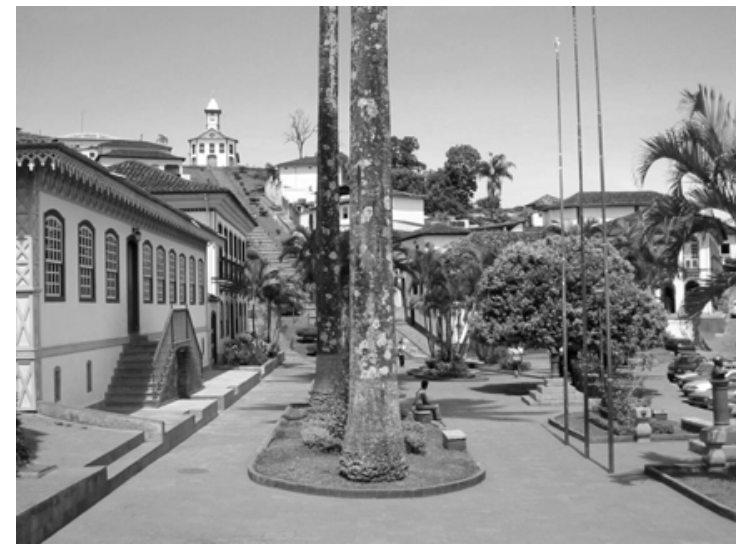

Figura 71. Praça João Pinheiro - igreja Santa Rita

Fonte: EA UFMG (2006), PDM, Serro

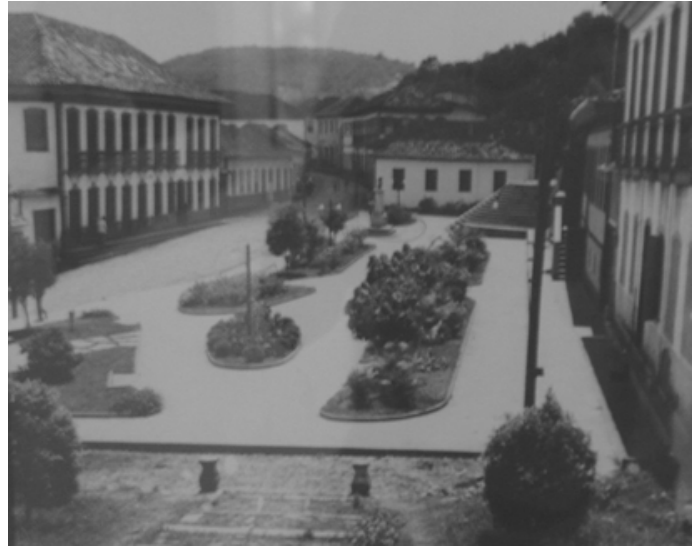

Figura 72. Praça João Pinheiro após 1943 Fonte: IPHAN (2006)

Desde sua origem, a praça João Pinheiro demonstrou vocação para o uso público oficial (treinamento das milícias), social e de lazer, que foi reforçado no início do século XX com a transferência da Câmara da praça da Matriz para o então largo da Cavalhada. Serro vinha seguindo o seu ritmo de transformação, mais intenso em épocas de dinamismo econômico, e mais lento em tempos de estagnação. 


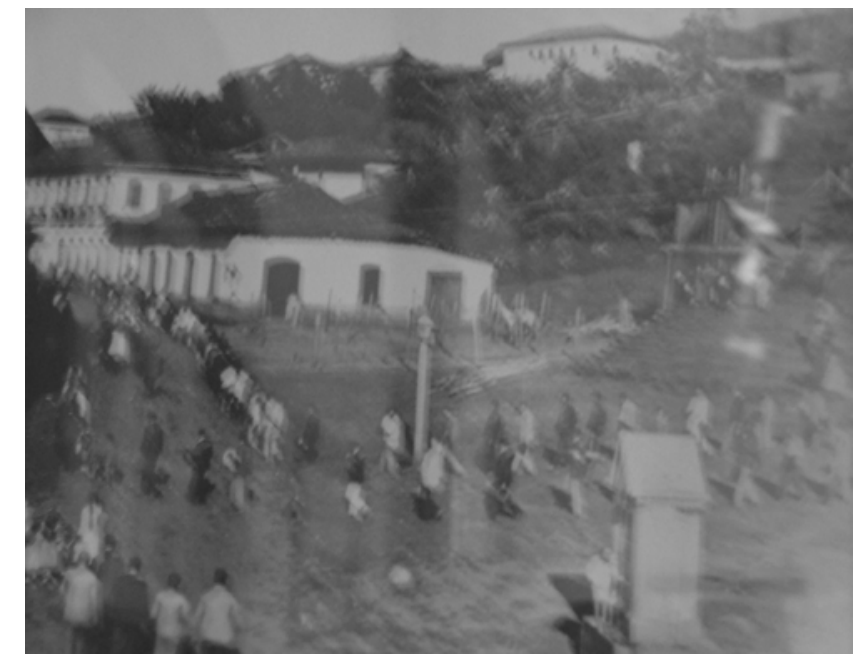

Figura 73. Largo da Cavalhada - foto sem data (primeiras décadas do século $X X$ ) Fonte: IPHAN (2006)

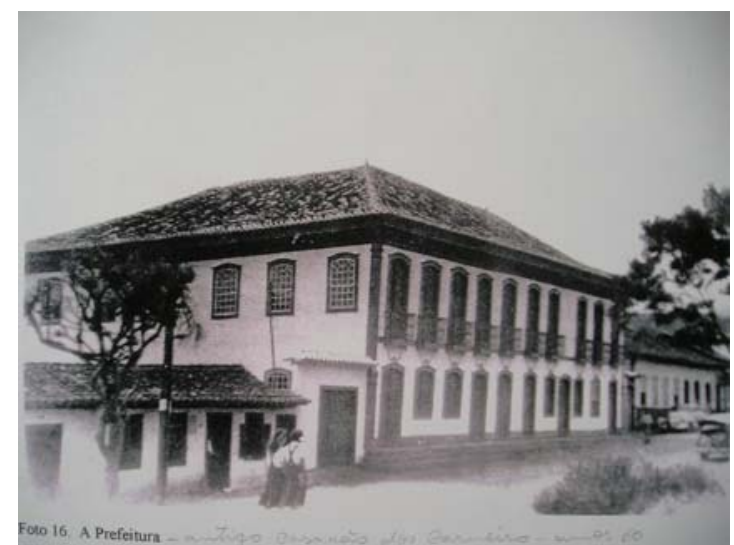

Figura 74. Largo da Cavalhada - Prefeitura Fonte: IPHAN (2006)

O largo pavimentado em seixo rolado, sem definição de limites, terminava junto às escadarias e muro do adro da igreja de Nossa Senhora do Carmo, escadaria da igreja Santa Rita e fachada das edificações que o contornam. Não havia rua no largo, este tipo de caminho convergia para a "praça", que recebia e distribuía os caminhos; portanto, não havia calçadas. No começo do século XX, colocou-se um coreto e vegetação na praça, sem mudar o seu desenho.

Em 1943, por intervenção do exército brasileiro, o largo da Cavalhada, para receber o busto de general Carneiro, teve a pavimentação removida, o terreno foi recortado e nivelado. Criou-se a praça João Pinheiro, com jardins, canteiros, marcação de rua e calçada, e fechamento do beco do Carmo.

Esta, talvez, tenha sido a intervenção de maior alteração na "'cidade antiga" de Serro. Contudo, a partir dela, outras ocorreram no mesmo local, sempre no sentido de sua manutenção. Será que o beco do Carmo ficará sempre interditado? 
É curioso que todas essas obras tenham sido realizadas após o tombamento do Serro. E atrelado a essa descaracterização urbana, ocorreram substituições de vários exemplares arquitetônicos da praça, algumas fortemente questionáveis. Recentemente, na década de 1990, conforme evidenciamos através da Figura 75, na praça João Pinheiro foram substituídas duas casas térreas por um único volume.

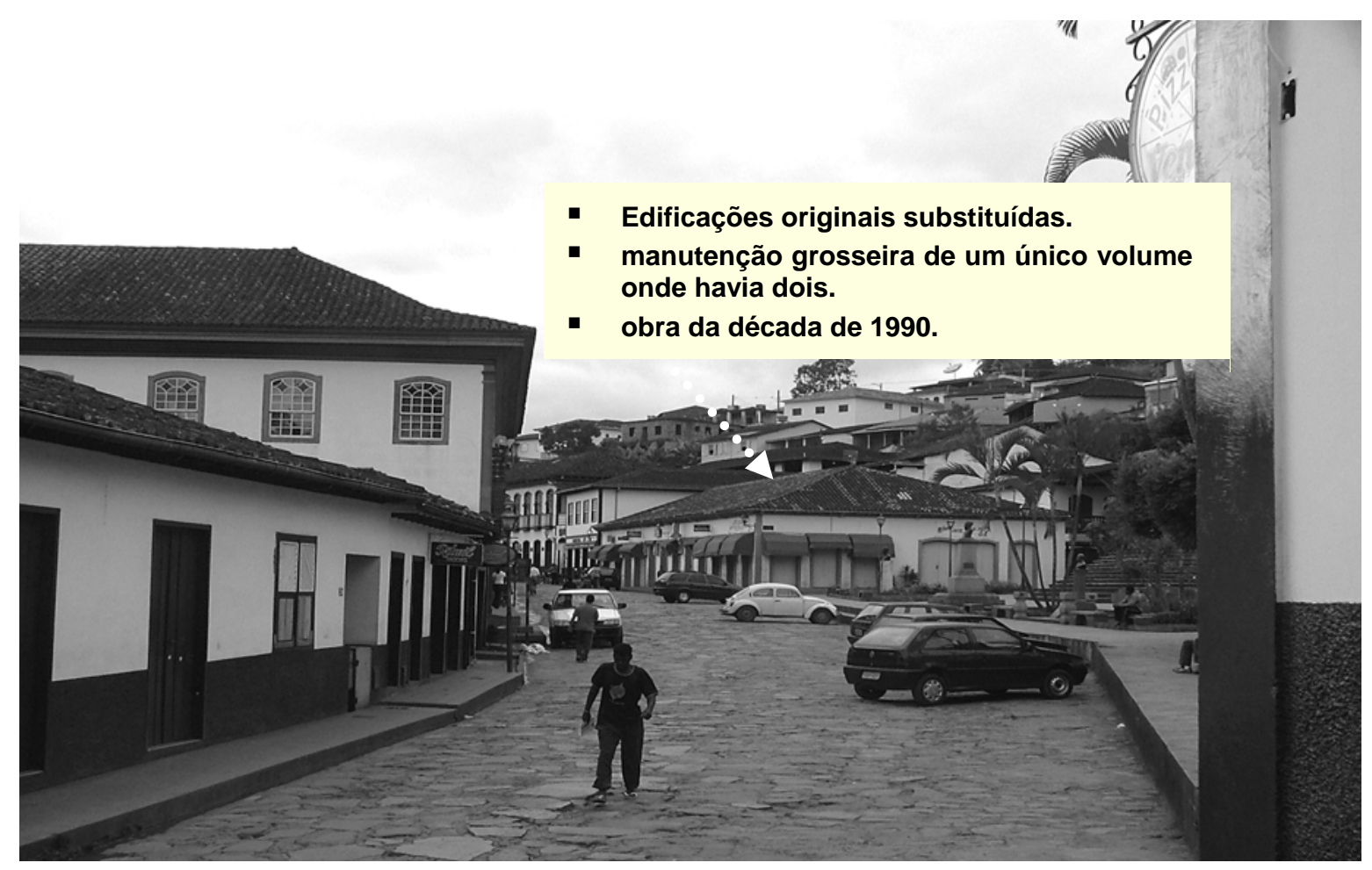

Figura 75. Praça João Pinheiro - rua Antônio Honório Pires - junho de 2006.

Destas modificações arquitetônicas, aquelas referentes ao emolduramento da praça são expressivas tendo em vista a elevada declividade da área, atrelada ao adensamento e parcelamento do solo. Neste sentido, é evidente a ocupação recente 
da encosta que a encerra eliminando parte da "área verde" que envolve a igreja Nossa Senhora do Carmo e suas edificações vizinhas.

Conforme Castriota (2003), "a persistência estabilizadora do lugar como um contenedor de experiências que contribui tão poderosamente para a sua memorabilidade intrínseca", contribui para a denominação do que se identifica como "memória do lugar". Dolores discute como acontece a relação entre a preservação do ambiente construído, a história pública e a memória social. Entendemos que a ação que visou a homenagem militar ao serrano general Carneiro através da transformação do bem tombado "Largo da Cavalhada" em "Praça João Pinheiro", ignorou a "memória do lugar", a memória social aí depositada. A história local, as relações sociais, econômicas, culturais, religiosas, formais e artísticas que compõem a fisionomia do lugar e a vida de uma cidade se modificam ou desaparecem, para dar lugar a um símbolo militar. O que aconteceu com a ação de preservação do Estado?

Não podemos nos surpreender com a ausência de "memorabilidade" do lugar por sua população, constantemente excluída da formulação das políticas de preservação. A falta de informação e educação cultural representaria uma colaboradora para esta exclusão dos indivíduos do processo de transformação de sua cidade? Esse mesmo fator não os leva a denegrir, danificar seu próprio patrimônio pela ausência de uma consciência da memória local? Com isso, segundo Albano (1994), o Estado se tornaria o verdadeiro "guardião" da cidade, e os moradores opositores à preservação ou, mesmo, transgressores. Entretanto, no Serro não é exatamente o que aconteceu e nem o que está acontecendo. 
Conforme observamos no caso do largo da Cavalhada, onde o dano foi causado pelo próprio Estado (poder público), é assim que vem se procedendo em inúmeras situações, em sua maioria por desconhecimento. Serro, até a segunda metade do século $X X$, encontrava-se praticamente isolada, as vias que the davam acesso não tinham pavimentação. Atualmente, mantém apenas um caminho rodoviário pavimentado. Essa realidade a colocou, de certa forma, "à margem" em vários seguimentos da economia e política, e não foi diferente quanto à presença do Estado em sua preservação.

Em parecer de 1958 quanto a obras de conservação em Ouro Preto, Lúcio Costa demonstra preocupação em investir melhor na cidade, para receber o turismo, que se tornou criador de fortes impactos na vida cotidiana de várias cidades setecentistas mineiras, com a redefinição de uso e ocupação no centro histórico e transformação de habitações e infra-estrutura (hotéis, comércio, serviços em geral) para receber os visitantes. Entretanto, Serro ainda não apresenta essa demanda. Apenas nesses últimos anos, com o surgimento da marca "Estrada Real", é que Serro se viu condicionada a se preparar e investir nesta indústria que aquecerá sua economia, mas que trará novas demandas quanto à preservação de seus bens culturais.

O que era preocupação do IPHAN em Ouro Preto há quarenta anos ainda não faz parte da realidade do Serro. Mas outros temas são constantes, como a ocupação de encostas, adensamento de áreas centrais e, principalmente, parcelamento do solo, que representa grave dano à estrutura urbana tradicional conforme nos aponta Camillo Sitte (1992) em suas análises do espaço urbano. 
O IPHAN foi criado em 1937 no Rio de Janeiro (capital do Brasil), exercendo sua atribuição de responsável pela preservação do patrimônio histórico e artístico nacional. Sua estrutura administrativa foi se ramificando com o passar dos anos. Minas Gerais possuía um Distrito Administrativo, sediado a princípio em Ouro Preto e posteriormente transferido para Belo Horizonte, com um diretor e auxiliares administrativos essenciais. Nas cidades tombadas do interior, existiam profissionais da construção civil contratados para realizarem obras de restauração e conservação arquitetônica, que acabavam se tornando contatos locais e posteriormente funcionários da instituição. Na década de 1980, Serro era atendido por um mestre de obras, que seguia orientação direta de outro profissional de Diamantina com nível médio de escolaridade, mas com reconhecimento de sua prática profissional, realizava um trabalho heróico, assim como outras figuras do IPHAN pelo Brasil.

No final da década de oitenta, o patrimônio cultural de Serro era acompanhado, em sua rotina de fiscalização e conservação, por esse profissional, que fazia esse mesmo trabalho em Diamantina (dois núcleos urbanos tombados, com seu acervo de bens arquitetônicos protegidos individualmente e um museu em cada umas dessas cidades, na responsabilidade de uma única pessoa). Demandas maiores ou excepcionais eram encaminhadas para Belo Horizonte ou Rio de Janeiro, o que exigia um tempo técnico e restrições geográficas que condicionavam respostas. Era possível um acompanhamento adequado?

Apenas na década de 1990 foi criada a Sub Regional do Serro (14 ${ }^{\mathrm{a}} \mathrm{SubR}$ ), com responsabilidade pelo Escritório Técnico e Diretoria do Museu Regional Casa dos Ottoni, exigindo acúmulo de função por um único diretor (até hoje têm sido 
arquitetos), mas estava concretizada a instalação de um representante local, da Federação, na cidade tombada (nesta época o IPHAN conseguiu a instalação destes escritórios nas principais cidades tombadas de Minas - atualmente apenas Cataguases não possui). Esta deficiência de trabalho em Serro, até a década de 1990, possibilitou danos irreparáveis ao seu acervo protegido por lei, com a eliminação e perdas de edificações inteiras por toda a estrutura urbana setecentista. Dessas lacunas, muitas já foram preenchidas e pelo menos trinta ainda estão vazias.

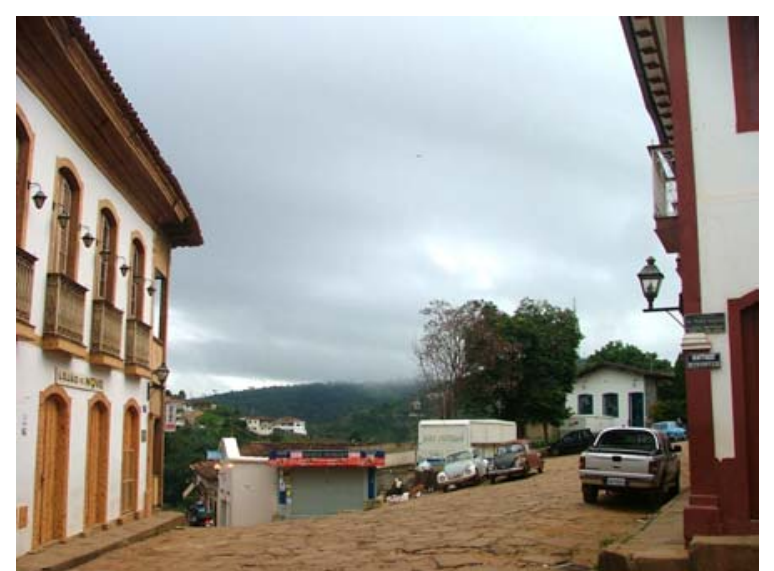

Figura 76. Lacuna referente a demolição da Igreja Nossa Senhora da Purificação - atual praça Dom Epaminondas, abril de 2006.

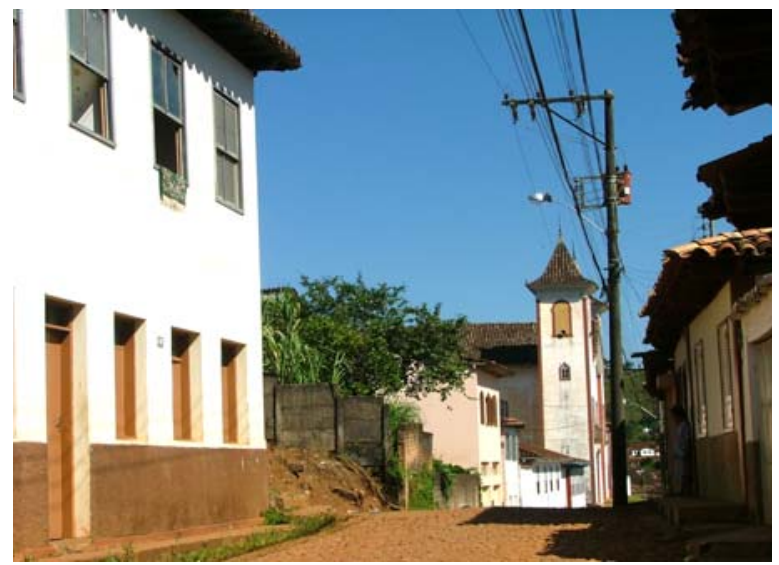

Figura 77. Lacuna referente a arruinamento de sobrado à rua Nelson de Senna, abril de 2006. 
CINJUNTD ARQUITEONICL E URBANESTICD TUMBADL DE SERRD

E MaNuMENTOS RELLGIOSOS

$\square$ LACUNA UREANA

para Belo Horlxante

o
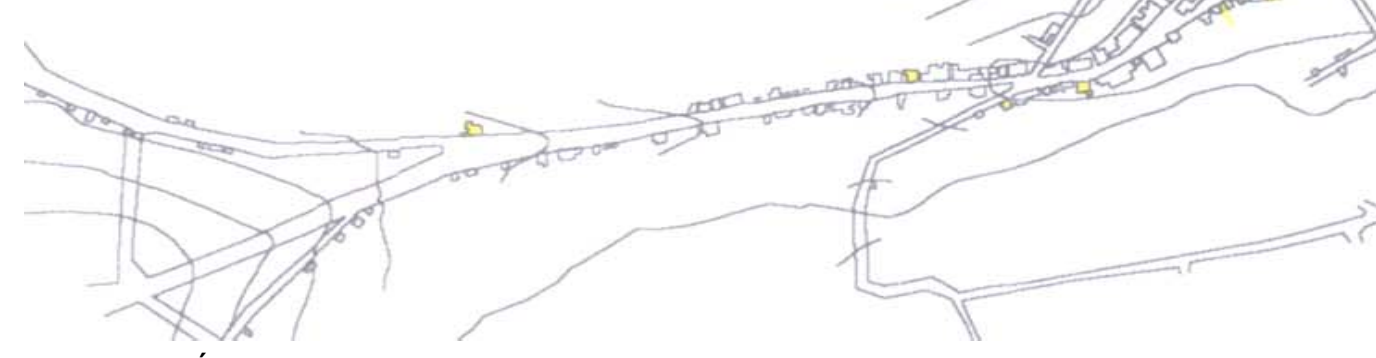

Figura 78. Área de ocupação tradicional de Serro (pontinhos amarelos: lacunas por perda de edificação; pontinhos vermelhos: igrejas). 
Entretanto, o maior comprometimento da cidade se deu não por lacunas decorrentes de eliminação de edifícios, mas por acréscimos, em sua grande maioria muito recentes (predominantemente na década de 1990). A ação de um diretor não preparado, responsável pelo Escritório Técnico do Serro durante 10(dez) anos de 1993 a 2003, causou à "cidade tombada" danos que não teve em toda a sua existência. Reconstruções, falsificações, adensamentos, parcelamento do solo, alterações volumétricas e de acabamento arquitetônico, dentre inúmeras outras intervenções, na região mais antiga da cidade, comprometeram expressivamente sua natureza plástica, alterando seu tecido figurativo, conforme nos indica Brandi (2005). Será que Serro mantém sua "unidade potencial"?

Conforme verificamos e estamos ilustrando por meio de imagens neste trabalho, é possível ainda vislumbrar muito do que Saint-Hilaire (1975) descreveu da Vila do Príncipe em sua viagem de 1817 (Figura 79 e Figura 80). Será que é possível restaurar o espaço urbano de Serro?

Entendemos que cidades como Serro vivem atualmente um momento de dúvidas e opções no que se refere a uma perspectiva sustentável de desenvolvimento. Serro manteve-se em um constante desaquecimento industrial ao longo do século XX. Constratando com esta constante inércia econômica, o turismo é visto como uma alternativa econômica importante, tanto para a sociedade quanto para seus administradores. Entretanto, as políticas de preservação implementadas na cidade não favorecem o desenvolvimento deste modelo de crescimento. 


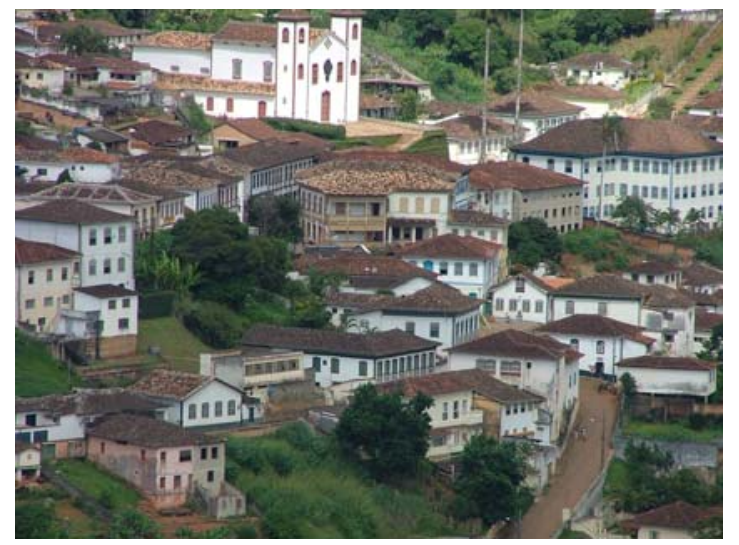

Figura 79. vista panorâmica do Serro Igreja Nossa Senhora do Carmo.

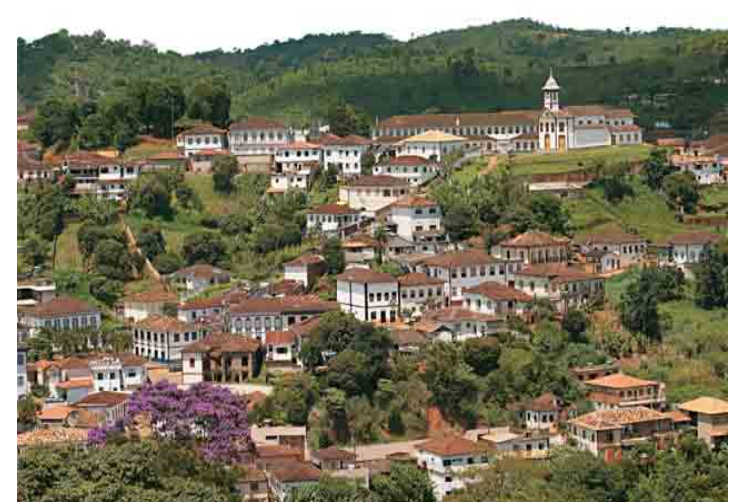

Figura 80. vista panorâmica do Serro - Igreja Santa Rita.

Fonte: www.descubraminas.com.br

Para Castriota (2003), ao analisar Ouro Preto, o turismo se mostra como uma "contraposição entre uma espécie de falsa tradição, para consumo externo, e uma tradição secreta local, que se mantém à margem e à revelia das políticas de preservação". Será que o turismo pretendido pela marca "Estrada Real" na cidade de Serro, será como esse?

\subsection{O estado da forma urbana}

Conforme discutimos no capítulo primeiro desta pesquisa, em "o método formal", tendo como referência a "Escola Italiana" de morfologia urbana, compreendemos o que significa "forma urbana" para Muratori (1959), que nos 
indicou a importância das análises sobre como as cidades deveriam ser traçadas, tendo como referência as tradições históricas. E no que se refere à preservação e restauração urbana, estamos convencidos de que o estudo da forma urbana é igualmente necessário. Neste sentido, buscaremos compreender o estado atual da forma urbana de Serro, com o auxílio dos ensinamentos contidos nos princípios artísticos de Camillo Sitte (1992).

Bittencourt (1999), ao se referir ao Serro em sua tese de doutorado, afirma: "o que é gritante aos olhos, ainda hoje (apesar dos anos de insensata descaracterização, por abandono ou reformas descabidas), é a impressionante coesão apresentada pelo conjunto". Para ele isso se deve, sobretudo, às relações harmônicas vinculadas à escala do observador e à sua capacidade de "perscrutar pelo olho".

O valor estético atribuído aos espaços urbanos, estudados e analisados por Camillo Sitte (1992) (há mais de 100 anos), está vinculado a esta escala do observador e de seu olhar sobre a cidade, comprovando-se sempre atualizados. Dentre inúmeras situações, podemos considerar como bom exemplo disto as considerações apontadas por Bittencourt (1999).

Através de uma releitura ou, mesmo, de uma transposição do que se entende por cidade antiga em Camillo Sitte (1992), acreditamos que a cidade de Serro com suas referências barrocas confirma-se como integrante de um grupo, tal como o daquelas valorizadas esteticamente por Camillo Sitte, pois, de acordo com ele, 
apesar de o barroco se divergir dos princípios básicos da antigüidade, "alcançou um requinte muito particular na arte da construção urbana" (SITTE, 1992).

Em seus estudos sobre a cidade, Camillo Sitte, em Städtebau, apresentou uma crítica à cidade moderna do ponto de vista comparativo com os espaços antigos. E, através da crítica à atitude daqueles que transformam a cidade em sua contemporaneidade, Sitte (1992) sustenta que, em seu tempo, não se preocupava com a elaboração da cidade enquanto obra de arte, mas com sua construção como um problema técnico. Percebemos que este entendimento se mantém ainda atual.

Acreditamos, assim como Kohlsdorf (1996), que Sitte realiza análises seqüenciais, buscando representar a passagem do que se vê para o que se percebe, através dos registros da composição morfológica de um determinado "espaço urbano livre" (principalmente praças). O que representa, normalmente, o reconhecimento do sentimento direto do indivíduo perante uma obra de arte. A concepção estética deste "espaço urbano livre", que é público: aberto, "vazio", representado pelas praças, largos e ruas, registra-se importante aspecto da obra de Camillo Sitte (1992).

Consideramos tal concepção e reflexão a respeito da beleza sensível e do fenômeno artístico determinado por estes espaços como fundamentais para o desenvolvimento de nossas análises em Serro.

é indiscutível que a obra [de Camillo Sitte] desperta um vivo estímulo à reflexão sobre a essência da qualidade deste espaço [público] assim como remete à reflexão sobre métodos de projeto do mesmo pelos profissionais engajados em tal tarefa (SALGADO, 2004, p.2). 
Para Salgado (2004), um dos principais objetivos de Sitte é oferecer ao profissional urbanista um material de estudo e de dedução para sua prática projetiva, entendendo que Sitte "moldou as idéias sobre a vida e a forma urbana" (SALGADO 2004). Camillo Sitte se coloca diante ao novo urbanismo de seu tempo, e argumenta que tradicionalmente, até aquele momento, a arte de construir espaços públicos livres se caracterizava pela construção de espaços visualmente fechados. E para Salgado (2004) "este é um dos principais argumentos de Camillo Sitte sobre os princípios artísticos de construção dos espaços públicos".

Em nossas análises da forma urbana de Serro, da sua materialidade, na busca pela verificação de um possível restauro urbano, partimos de espaços públicos livres, com o auxílio dos preceitos de Sitte (1992), na busca pela percepção dos princípios existentes nas várias praças da cidade, na verificação de suas concepções espaciais arquitetônicas diversas e na expectativa de uma concepção perspéctica que Ihes traduza uma artisticidade ou não. Para Camillo Sitte (1992), as praças principais das cidades antigas eram indispensáveis para a existência cotidiana destas, pois ali se desenvolvia parte da vida pública (em Serro podemos identificar a praça João Pinheiro, conforme Figura 70).

$\mathrm{O}$ arquiteto vienense demonstra, em seus estudos, certa preferência pelo pinturesco, e isso se mostra atrelado à leitura que ele realiza das qualidades artísticas da cidade antiga observada pelas perspectivas visuais. Tal preferência de Sitte (1992) é ainda percebida através da concepção estética dos espaços urbanos, entendidos por ele como "espaços visualmente fechados", onde ele apresenta seus 
principais argumentos para os princípios artísticos e concepções espaciais arquitetônicas.

\begin{abstract}
Para Camillo Sitte, a relação entre os edifícios na sua composição espacial deveria ser estabelecida de maneira que a percepção visual, dos mesmos, causasse no observador o efeito estético que remetesse a uma sensação agradável e reconfortável, acolhedora e bela. (SALGADO, 2004, p.3).
\end{abstract}

Esta maneira de perceber a cidade nos auxiliou a identificar percursos no espaço urbano de Serro, caminhos que confluem em praças - relacionadas, conforme Figura 81: praças João Pinheiro, Dom Epaminondas e Getúlio Vargas -, as quais analisaremos com especial consideração por suas características estéticas, formais, ou seja, são primeiramente as concepções espaciais do ambiente urbano (Figura 75, Figura 82, Figura 83, Figura 84) que importa compreender.

CIDADE DO SERRO - área de estudo Principais Praças tradicionais

LEGENDA:

Antiga Praça da Cavalhada atual praça J oão Pinheiro

Antigo Largo da Purificação atual Praça Dom Epaminondas

Antigo Largo do Pelourinho

atual Praça da Matriz ou Praça Getúlio Vargas

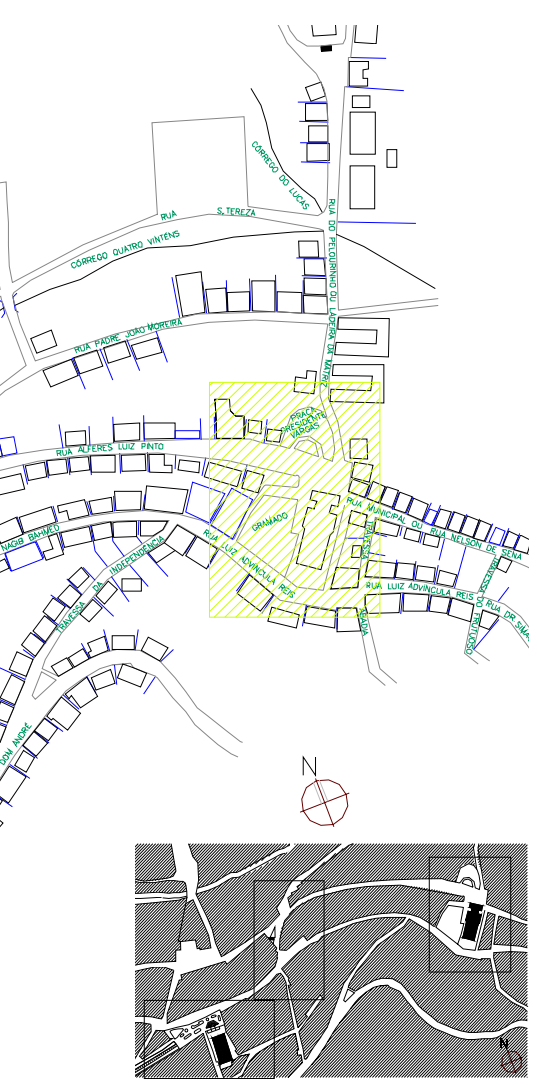

Figura 81. Principais praças de Serro estudadas nesta pesquisa - Praça João Pinheiro, Dom Epaminondas e Getúlio Vargas (da esquerda para a direita).

Fonte: adaptado de MC Arquitetos (2004) 


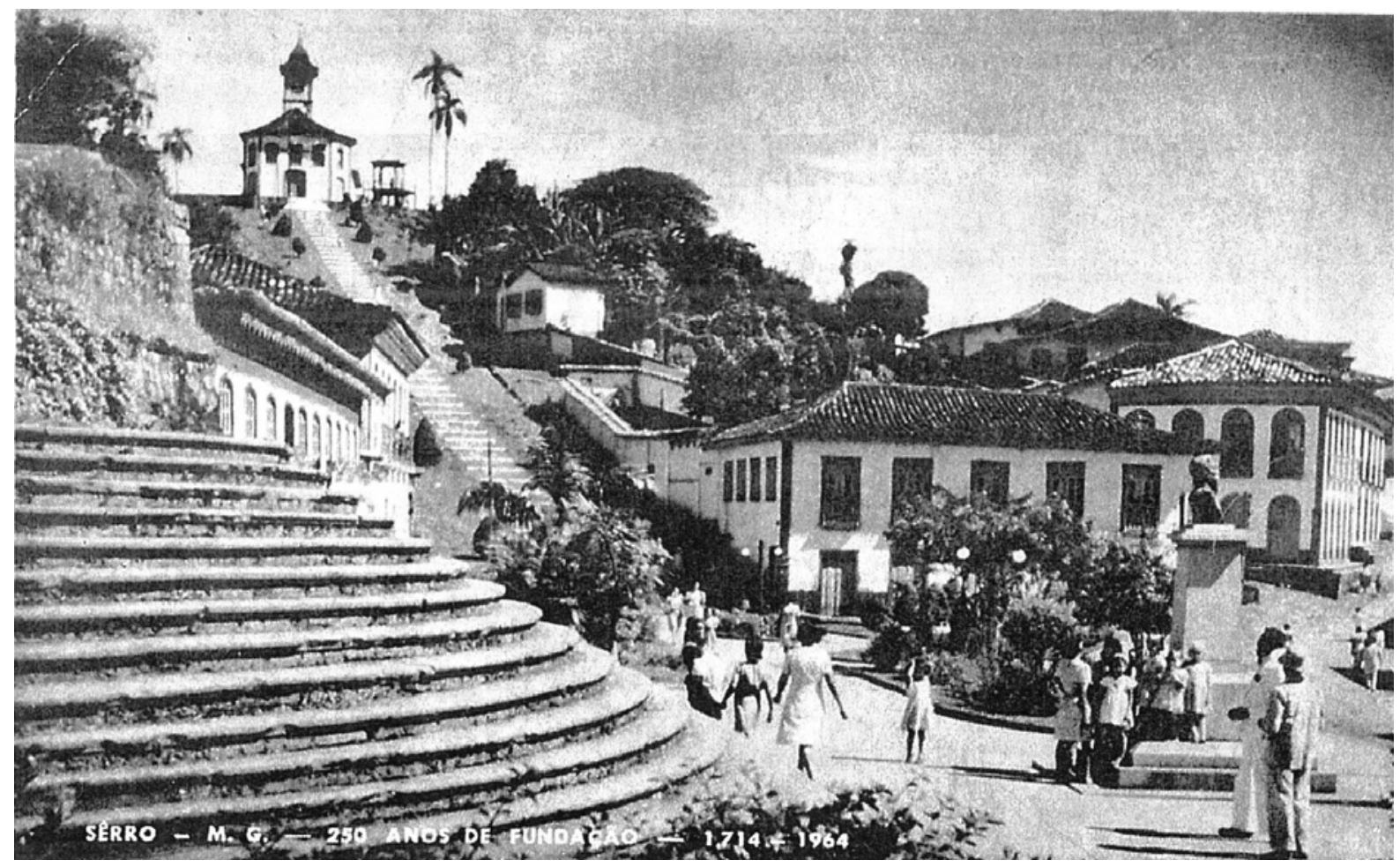

Figura 82. Praça João Pinheiro - antiga praça da Cavalhada - escadaria da igreja do Nossa Senhora do Carmo e igreja Santa Rita ao fundo

Fonte: IPHAN (2006)

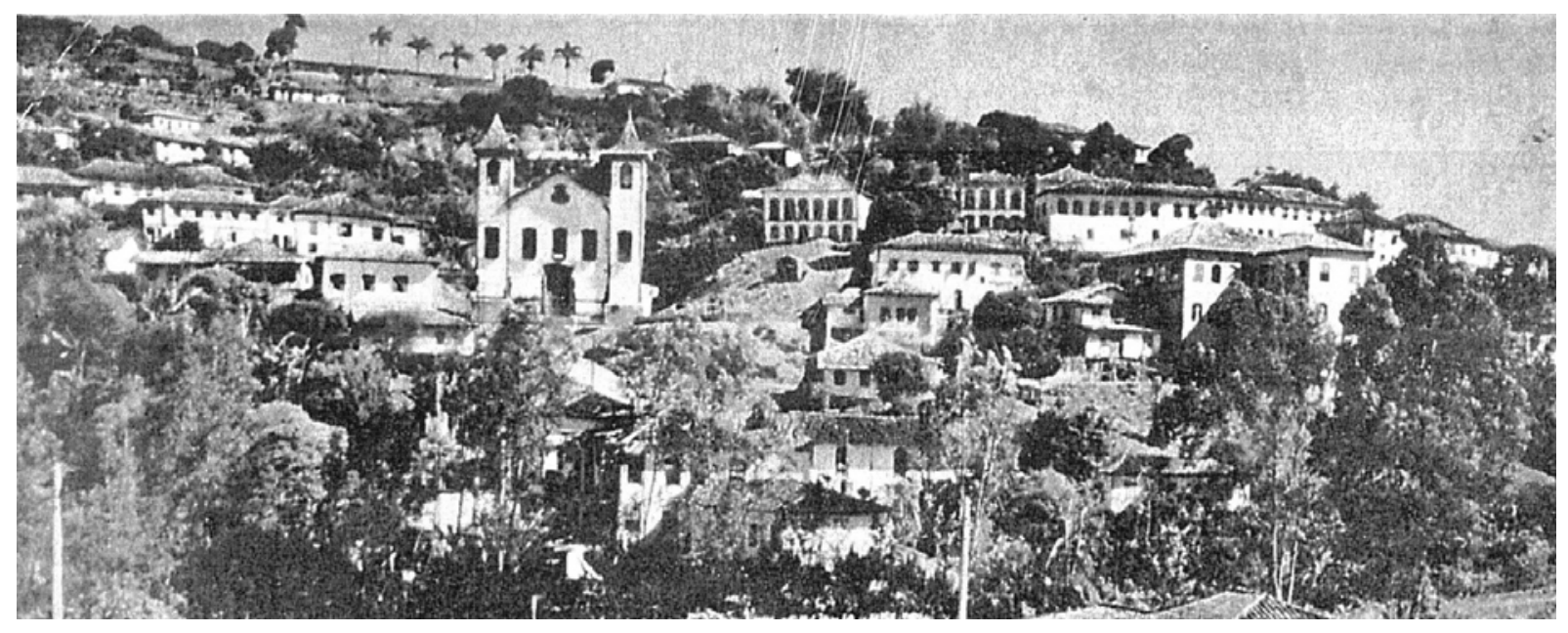

Figura 83. Praça Getúlio Vargas - antiga praça do Pelourinho - Igreja Matriz de Nossa Senhora da Conceição

Fonte: IPHAN (2006) 


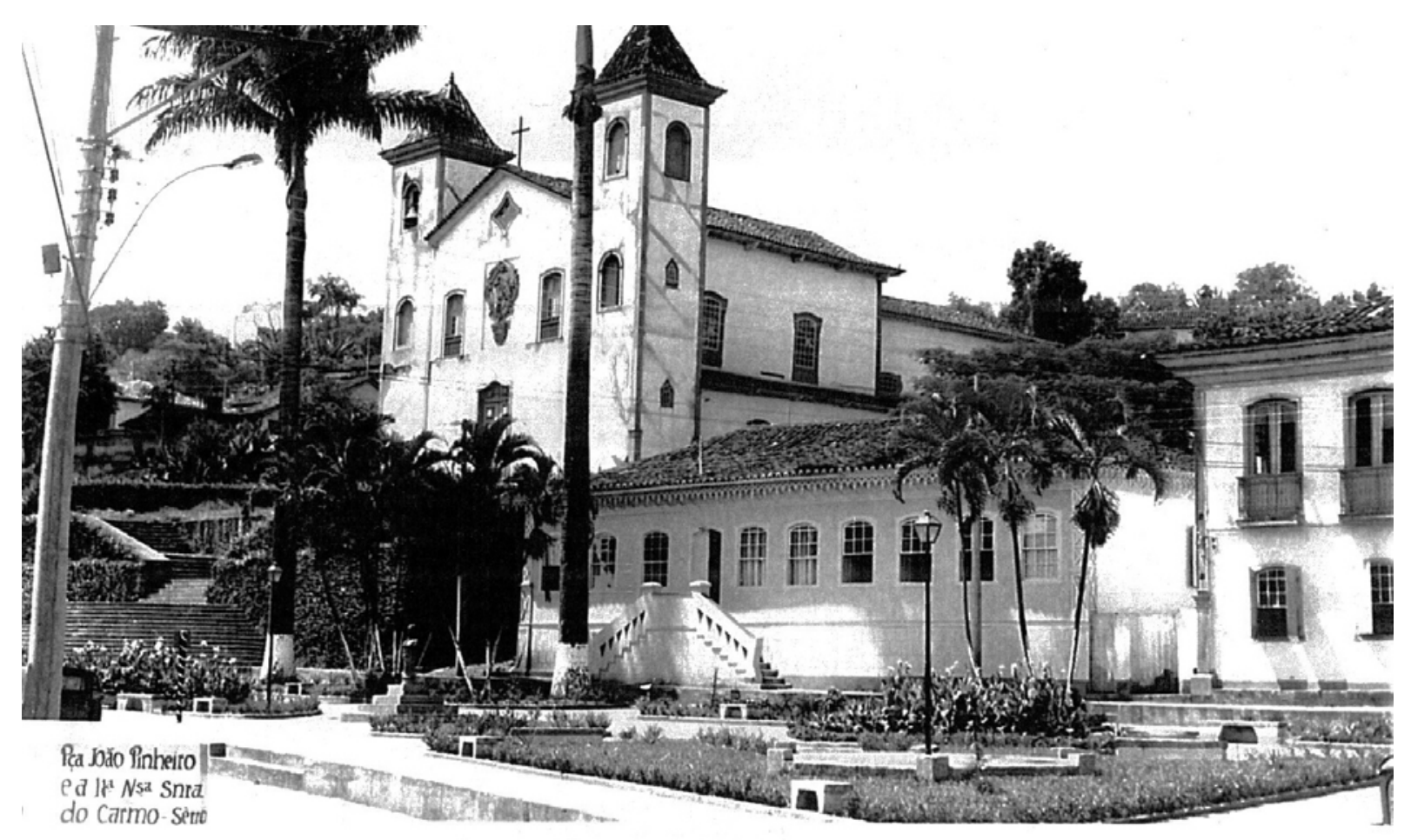

Figura 84. Praça João Pinheiro - antiga praça da Cavalhada - Igreja Nossa Senhora do Carmo Fonte: IPHAN (2006)

Para ampliar a percepção do significado do ambiente urbano em sua materialidade, nos valemos da dimensão visual da cidade de Serro, conforme princípios de Camillo Sitte. Em inúmeras situações, a topografia mostra-se como fator determinante no emolduramento ou fechamento do "espaço urbano livre". Neste sentido, uma vez que tal elemento interfere diretamente na percepção do espaço construído, entendemos ser fundamental ter ciência da topografia (Figura 85) e declividade (Figura 86) do território definidor de Serro, na certeza de que esta aproximação física possibilite maior conhecimento das relações arquitetônicas presentes na cidade, que poderão ser compreendidas em sua complexidade e 
simplicidade, onde se desvendarão importantes valores plásticos e estéticos de destacada importância em nossas pesquisas e discussões.

Observamos que, em Serro, surge como forte condicionante morfológico a expressiva relação entre os aclives e declives, que nos apresentam novos horizontes a cada momento de observação e percepção da espacialidade construída (Figura 85). O espaço visual da cidade é dinâmico e sinuoso, decorrente de sua implantação longitudinal em sintonia com as curvas de nível, em terreno de altos índices de variação topográfica, que acaba por representar importante definidor dos espaços urbanos, contribuindo de maneira decisiva para sua caracterização morfológica e espacial.

A percepção do espaço está efetivamente marcada pela altimetria, topografia e declividade da região onde a cidade se formou (Figura 88, Figura 89, Figura 90). Conforme indicação no "mapa de declividade" (Figura 86), a maior parte da área tradicional urbanizada, de ocupação pioneira, de Serro está com registros de declividade entre 30\% e 100\%. E, observando a inserção e distribuição da arquitetura na cidade, verificamos que a tipologia de grandes sobrados característicos da ocupação mais antiga de Serro deve-se muito ao elevado índice de inclinação do solo. Disso resulta a particularidade de construções de edificação em declive, (Figura 87), com o dobro ou mais pavimentos na fachada dos fundos se comparada com a fachada frontal, e o contrário a isso aquelas edificações em aclive, com dois pavimentos para a rua principal e um ou mais para os fundos. 


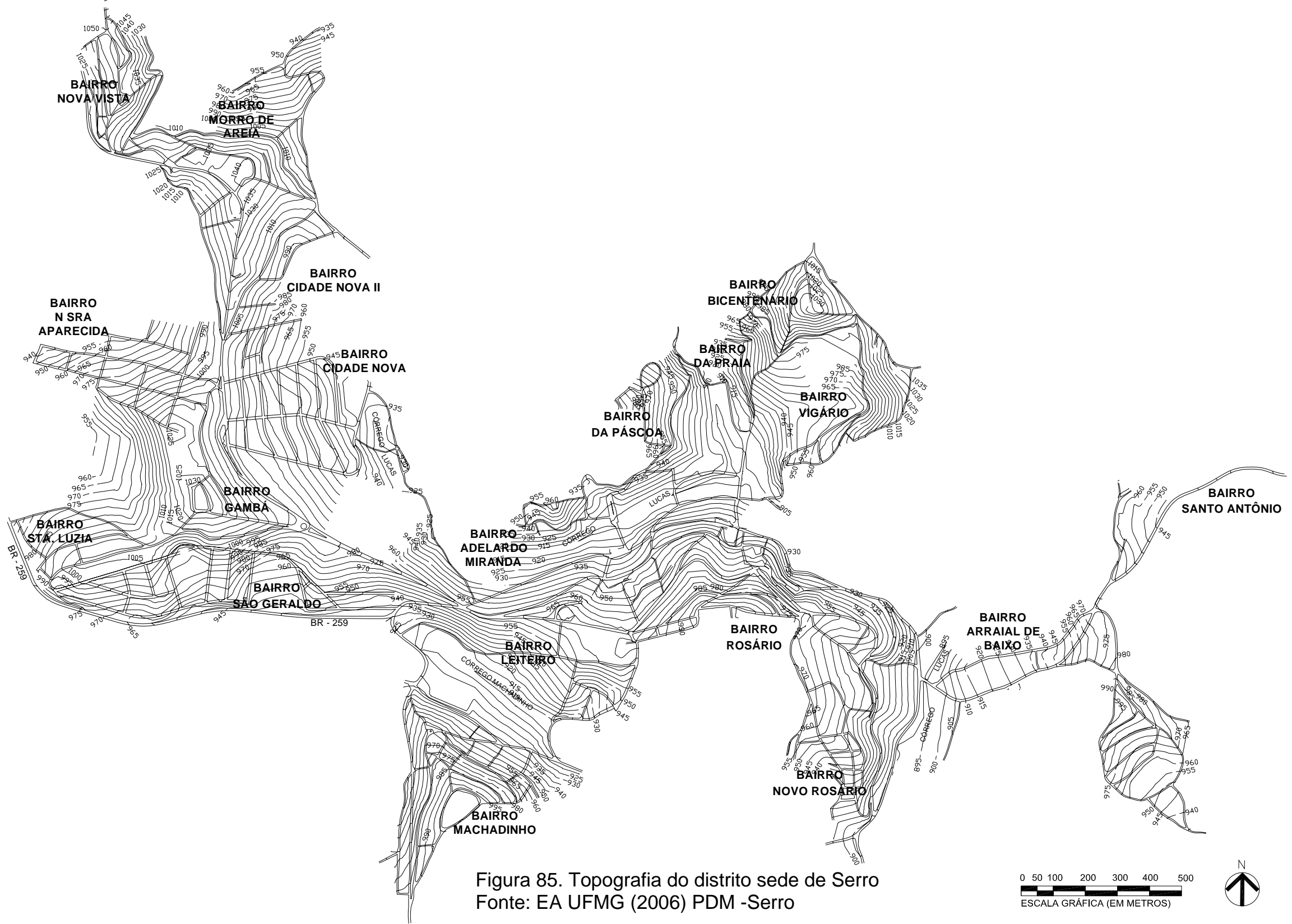




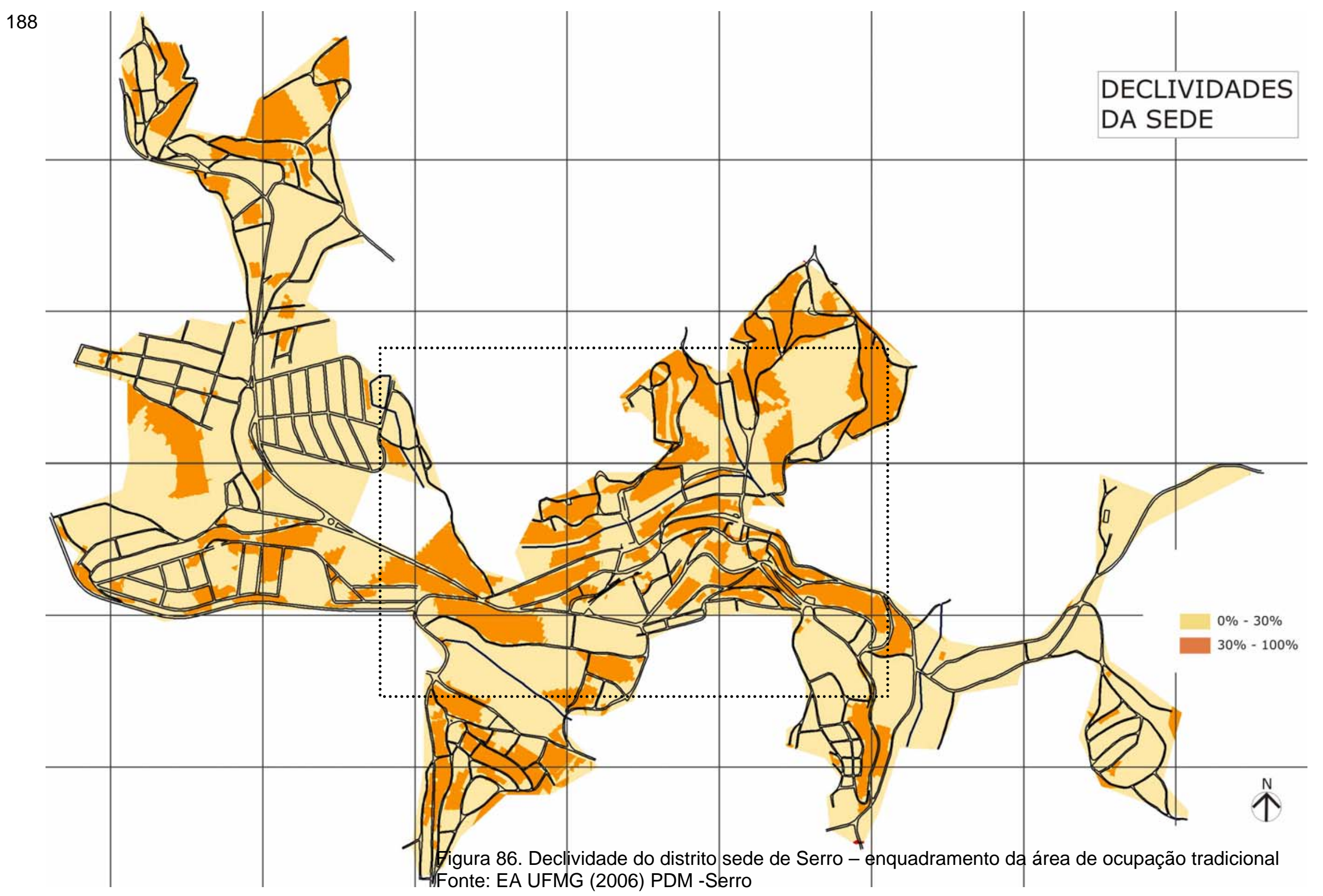




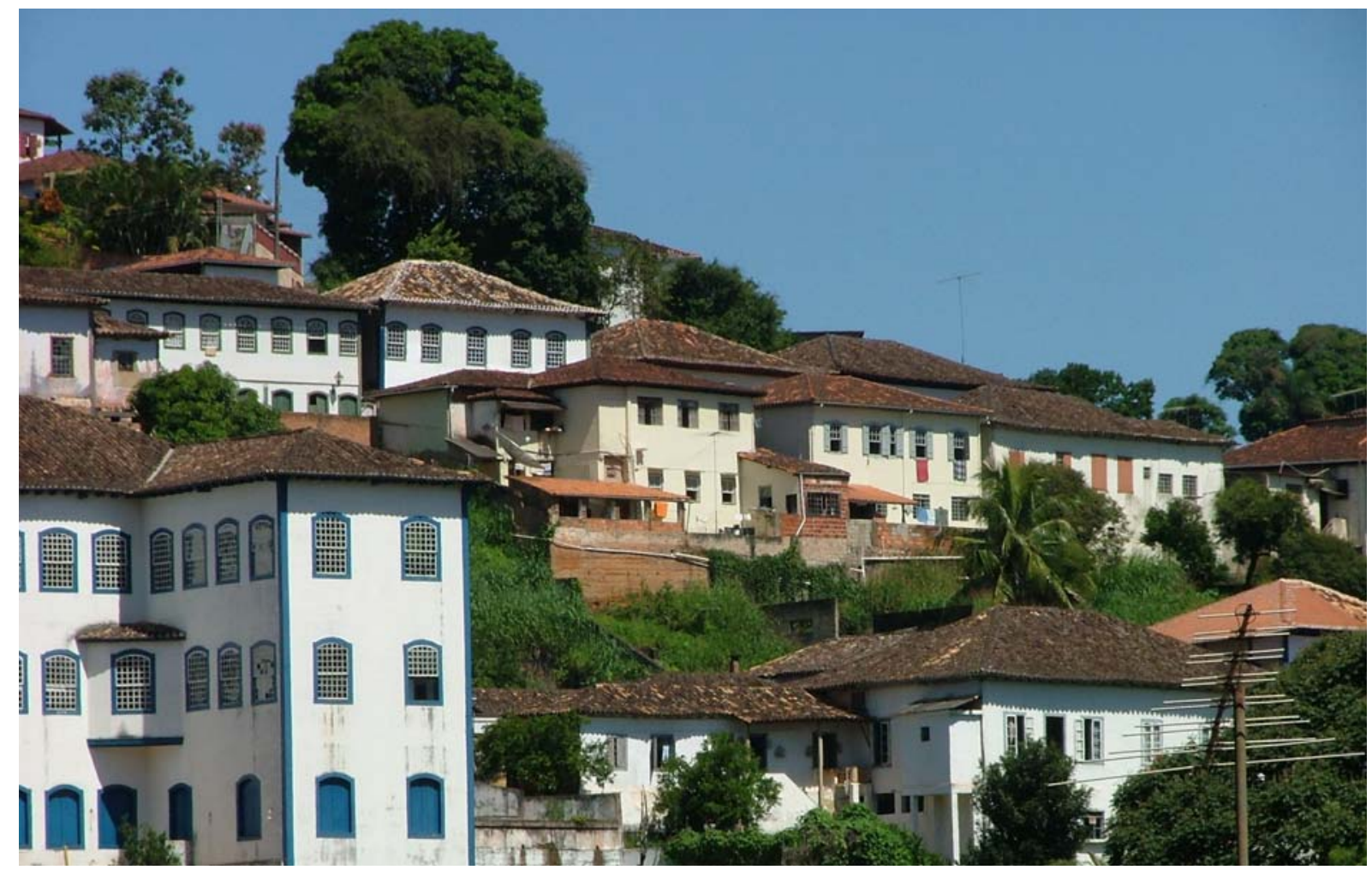

Figura 87. Declividade do Serro - condiciona a ocupação - edificação sobre terreno em declive

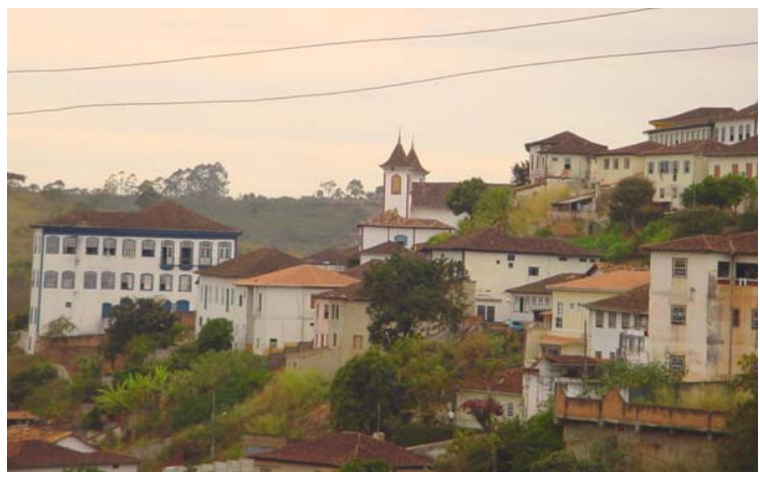

Figura 88. Vista parcial do conjunto urbano de Serro - perfil da implantação urbana

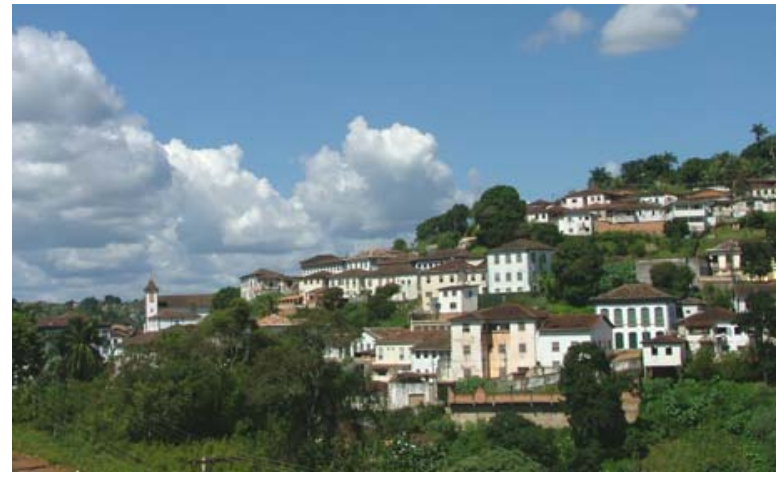

Figura 89. Vista parcial do conjunto urbano de Serro - forma de ocupação na encosta

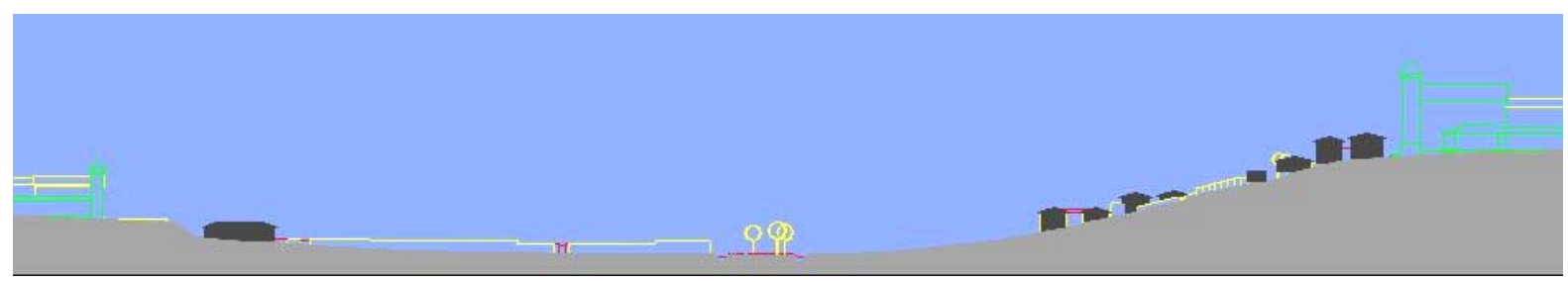

Figura 90. Corte esquemático do perfil topográfico da implantação urbana do Serro. Fonte: PROGRAMA MONUMENTA (2005). 
Tendo em vista a destacada importância que representam os elementos naturais e geográficos para o ambiente urbano, é pertinente que lembremos das referências portuguesas na urbanização brasileira.

\begin{abstract}
A cidade portuguesa é o resultado de várias influências e de várias concepções de espaço, que nela confluem e se sintetizam. Por um lado, uma concepção de espaço de natureza mediterrânica, vernácula e muito ligada à estrutura do território, que pode ser verificada nas cidades gregas, em que o elemento essencial, são os edifícios localizados em posições dominantes, que dão sentido e estruturam os espaços urbanos envolventes. Por outro lado, uma concepção de espaço racional, intelectual e abstrata, que, embora presente nas cidades romanas de colonização não é especificamente mediterrânica (TEIXEIRA, 2000, p. 2).
\end{abstract}

Historicamente, as cidades tradicionais construídas no Brasil possuem características morfológicas conforme tradição urbana portuguesa. Podemos citar características de destaque como: a lógica das suas localizações; especificidades topográficas do sítio; relação que estabelecem com o território; organização global da cidade e suas principais linhas estruturantes; características do traçado; estrutura de quarteirões e de loteamento; características arquitetônicas. Salientamos que com certa facilidade é possível identificar tais características morfológicas em Serro.

Verificamos que esta concepção urbana presente em Serro tem como uma de suas características mais importantes, a relação com o território, que pode ser observada na escolha de localizações, nas características específicas do sítio selecionado para a sua fundação, na eleição dos locais proeminentes para a implantação dos edifícios institucionais, na definição das principais vias estruturantes, que se inserem simultaneamente numa lógica territorial e urbana que as articula, no ordenamento global da cidade e definição do seu traçado, assim como no desenvolvimento de espaços urbanos com características formais específicas. 
A ocupação presente em Serro retrata uma capacidade de se moldar ao território, ainda que às vezes a partir da utilização de um relativo e menor rigor geométrico (Figura 88, Figura 89, Figura 90). Constatamos a escolha dos sítios topograficamente dominantes para a implantação do aglomerado urbano; a íntima articulação do seu traçado com a topografia; a localização dos edifícios institucionais de naturezas religiosas, civis ou militares em sintonia com as particularidades topográficas e o papel destes edifícios na estruturação do traçado urbano (Figura 91). Podemos perceber que o próprio processo de planejamento e de construção da cidade de Serro se concretiza na ausência de conflitos com a estrutura física e natural do território.

Serro é uma cidade de origem portuguesa que se desenvolveu junto a dois cursos d'água, em pendentes suaves: córrego Quatro Vinténs e ribeirão do Lucas. Em seu traçado, os pontos topograficamente dominantes do território são ocupados por igrejas. E a primeira grande via estruturante da cidade desenvolveu-se, no entanto, a uma cota mais baixa, relativamente próxima ao rio. É ao longo desse primeiro percurso que se definem os primeiros lotes e se constroem as primeiras casas, seguindo o seu alinhamento; e, num segundo momento, observam-se a ocupação dos pontos dominantes do território por funções urbanas e edifícios significativos, e o desenvolvimento de ruas dirigindo-se para eles. Essa característica de ocupação, conforme nos aponta Teixeira (2000), trata de padrão português de construção de cidades. 


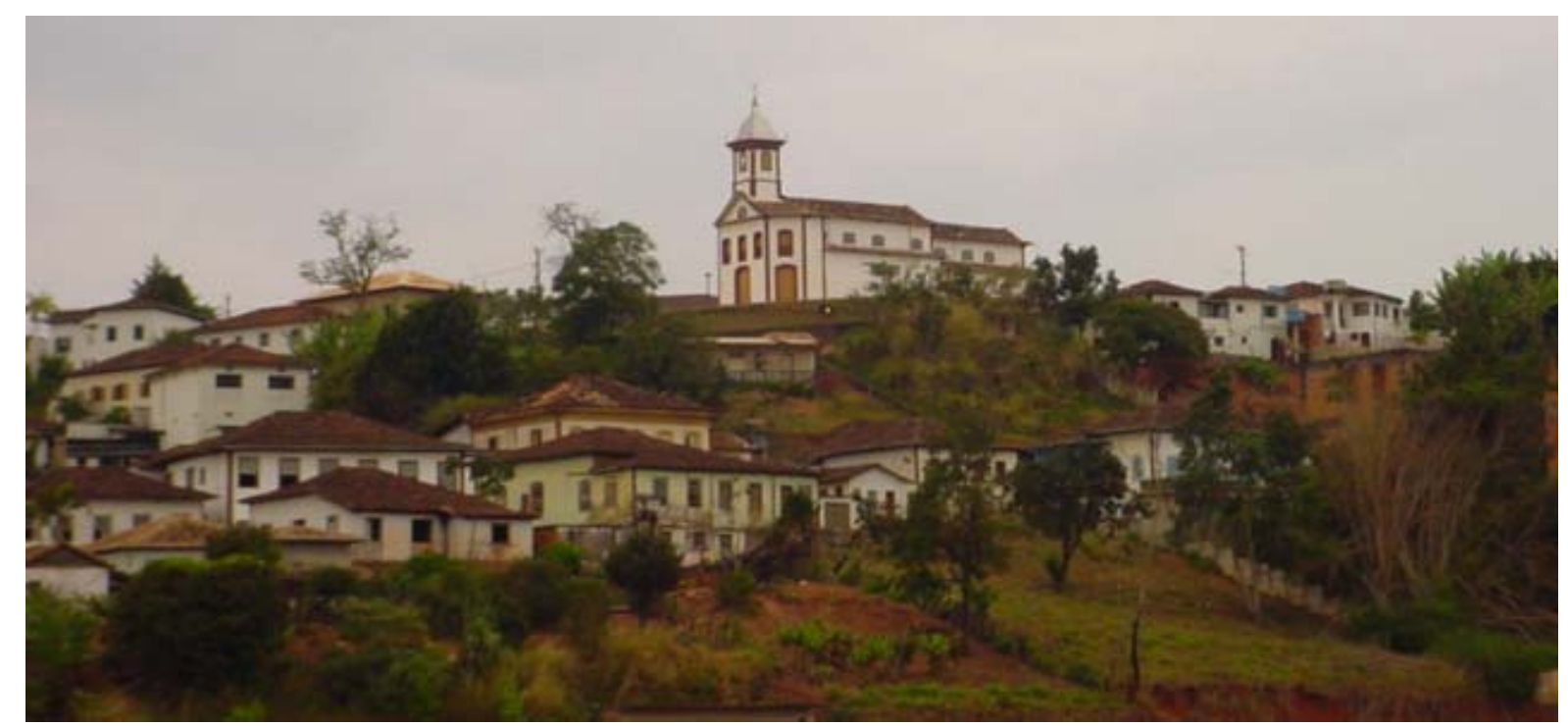

Figura 91. Vista parcial de Serro - destaque Igreja Santa Rita

Geralmente, as ruas que se dirigem para esses edifícios são perpendiculares ao eixo original, mas em pontos onde, apesar da grande inclinação, a pendente é menor. Tal característica representa importante referência de artisticidade indicada por Camillo Sitte (1992) no que se refere às condições geométricas das vias que chegam às praças. Entretanto, é importante lembrarmos que o traçado urbano de Serro representa uma ordenação de modo natural, territorial de construção da cidade, conforme princípios do conhecimento vernáculo do urbanismo português.

Destacamos, a partir de pesquisa do Departamento de Tecnologia da Escola de Arquitetura da UFMG, a distribuição predominante dos ventos na cidade de Serro, que percorrem os vales e colinas que definem a cidade, acompanhando a direção e sentido da ocupação tradicional setecentista (Figura 92). Essa realidade representa um indicativo de que a apropriação pioneira da área que representa a cidade se consolidou em sentido favorável a parâmetros de conforto ambiental, tanto 
pelos ventos conforme ilustra o mapa "distribuição de ventos" quanto pela insolação, tendo em vista sua implantação longitudinal em sentido leste-oeste.

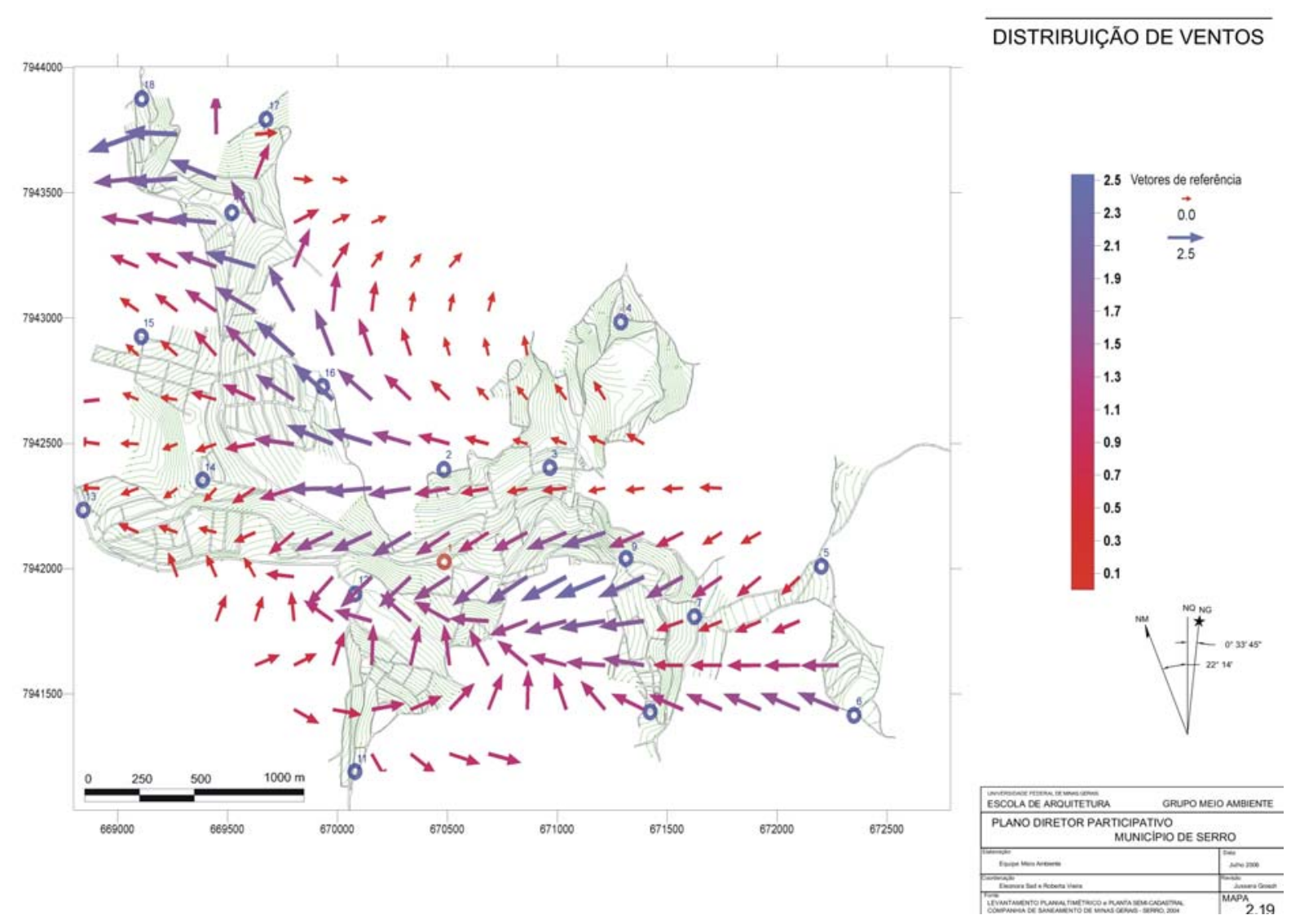

Figura 92. Mapa Distribuição de Ventos

Fonte: EA UFMG (2006) PDM - Serro

Tendo esses condicionantes como básicos, com o auxílio dos princípios artísticos estudados por Camillo Sitte (1992) avançamos nossas análises, em Serro, a partir do percurso entre o largo do Pelourinho ou praça da Matriz, denominada oficialmente por praça Getúlio Vargas, seguindo para a praça João Pinheiro, antiga praça da Cavalhada, percorrendo entre as praças anteriores a atual praça Dom 
Epaminondas, antiga praça da Purificação, para avaliarmos a relação continuada destes ambientes, a fim de identificar suas características e condições físicas.

Desenvolvemos investigação exploratória adotando princípios da percepção de forma intuitiva e apriorística a partir da qual a sensibilidade organiza a experiência sensorial, estabelecendo relações e distâncias entre os objetos percebidos de maneira simultânea até onde o ambiente urbano e as nossas limitações nos possibilitaram. Nessa trajetória, focamos constantemente o olhar na dimensão espacial do ambiente na busca pela compreensão de sua morfologia. Para isso, observamos os princípios artísticos desenvolvidos por Camillo Sitte, compreendidos conforme o capítulo primeiro desta pesquisa, utilizando como instrumento auxiliar os dados da Figura 13, Figura 14, Figura 15, Figura 16, Figura 17, Figura 18, que servirão ainda como elementos auxiliares de compreensão do objeto cidade.

Por uma questão restritiva e instrumental para um debate mais objetivo e direto, é que estamos realizando esta investigação urbana apenas nos trechos citados anteriormente, conforme ilustraremos a seguir, registrados pelo máximo de ângulos que foram possíveis no momento. 


\section{PRAÇA GETÚLIO VARGAS - praça da Matriz}

Conforme apresentamos no capítulo segundo desta pesquisa, a praça Getúlio

Vargas é das mais tradicionais de Serro. Representa o local do antigo pelourinho,

Casa de Câmara e Igreja Matriz da cidade (Figura 93, Figura 94).
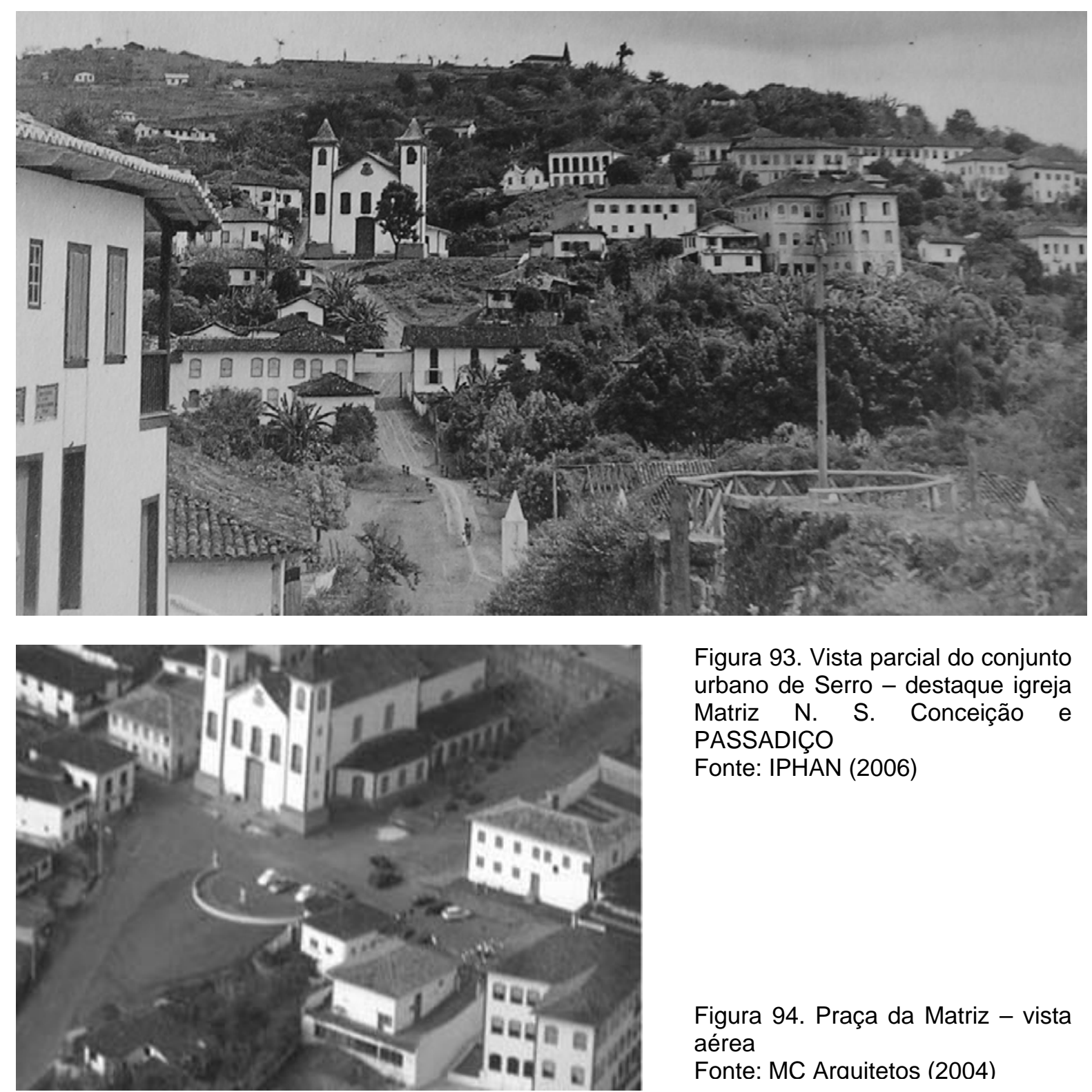

Figura 93. Vista parcial do conjunto urbano de Serro - destaque igreja Matriz N. S. Conceição e PASSADIÇO

Fonte: IPHAN (2006)

Figura 94. Praça da Matriz - vista aérea

Fonte: MC Arquitetos (2004) 


\section{A percepção da Praça Getúlio Vargas: Pela Ladeira da Matriz}

Ao percorrer o eixo de conexão da igreja Bom Jesus do Matosinho e a Matriz de Nossa Senhora da Conceição (Figura 95 a Figura 98), percebe-se que há acentuada diferença de nível topográfico. Ao passar pela área de várzea na confluência do córrego Quatro Vinténs e ribeirão do Lucas em direção à encosta de ocupação tradicional da cidade historicamente mais densa, onde se localiza a igreja Matriz de Nossa Senhora da Conceição, deparamos com a ladeira da Matriz, uma via perpendicular às curvas de nível que desemboca diretamente na fachada principal da Matriz (Figura 97, Figura 98, Figura 99), que representa arquitetura de escala monumental.

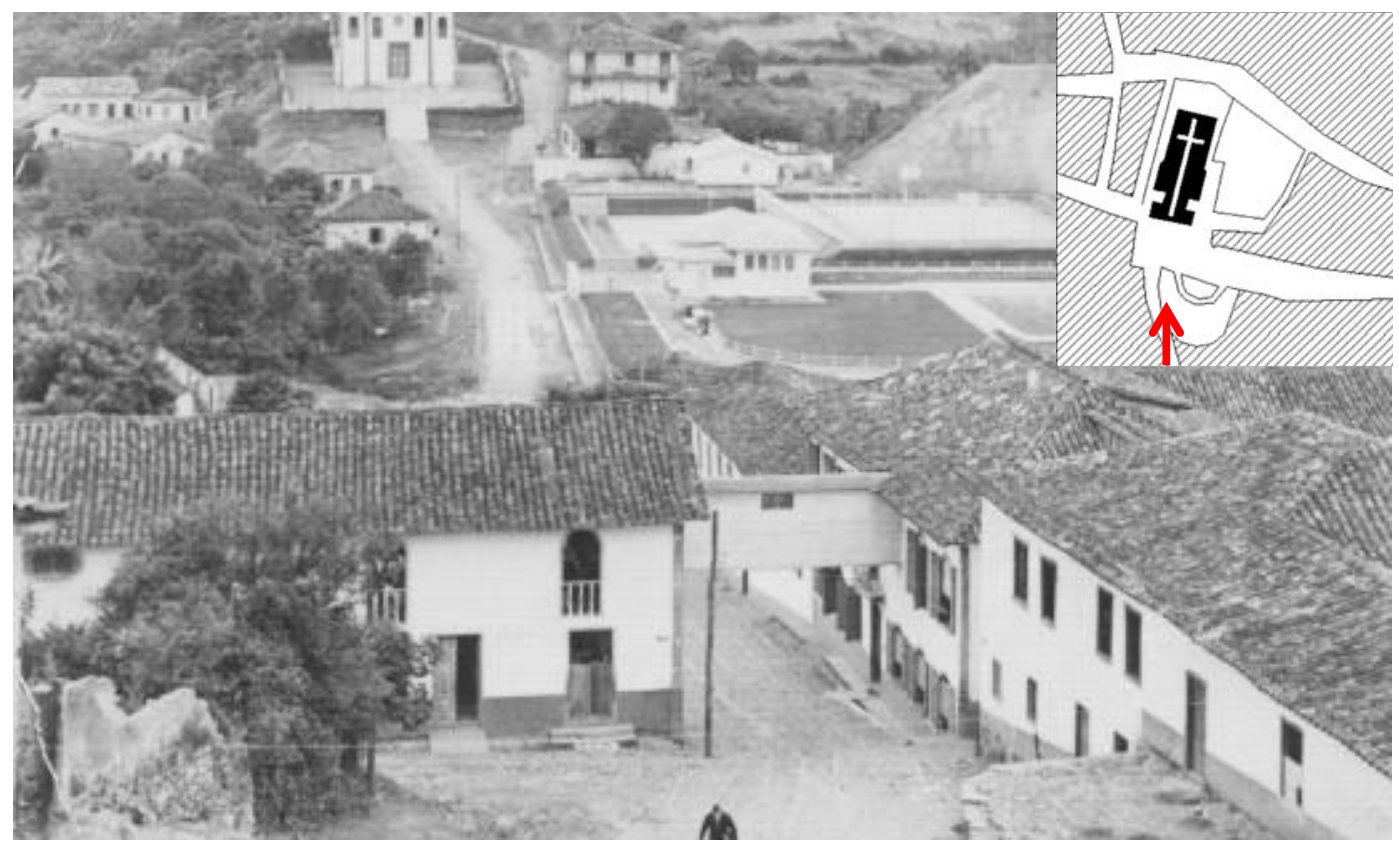

Figura 95. Serro (MG) - Ladeira da Matriz, passadiço do colégio Nossa Senhora da Conceição; ao fundo igreja Bom Jesus do Matosinho

Figura 96. Mapa de localização do observador em direção à praça Fonte: IPHAN (2006) 

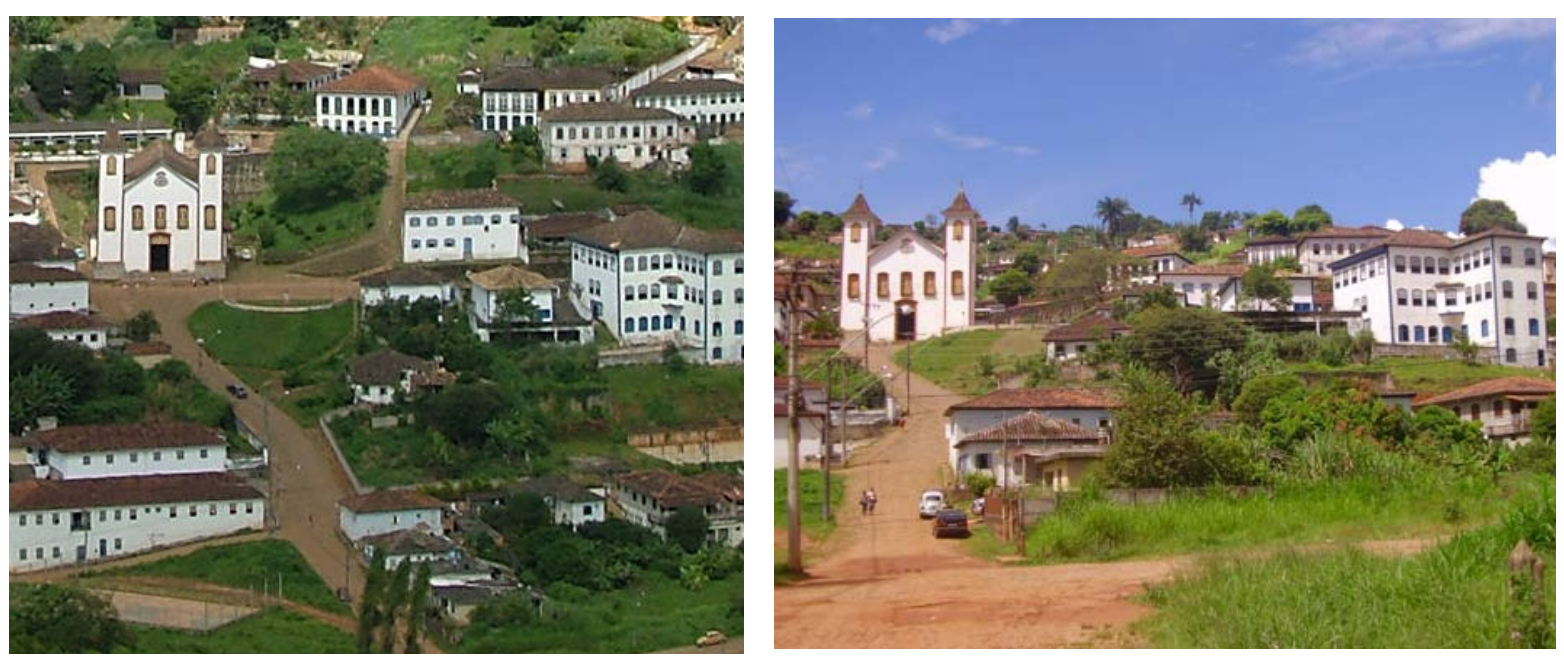

Figura 97 e Figura 98. Praça da Matriz ou Getúlio Vargas e Ladeira da Matriz

Descortina-se, então, a praça Getúlio Vargas, que deste ponto de vista mostra-se como um pequeno largo comprimido pela imensa igreja (Figura 100, 101). Entretanto, ao virar-se para direita, observa-se amplo largo que se encerra com a silhueta de uma rua que aparentemente termina no casario em curva para a direita (Figura 102, 103). A praça se encerra rapidamente, à esquerda, pelo casario que constrói linha contínua junto à Igreja Matriz (Figura 100, 101).

Figura 99. Percepção da Praça da Matriz (Praça Getulio Vargas) - acesso pela ladeira da Matriz

Fonte Seqawa (2004)

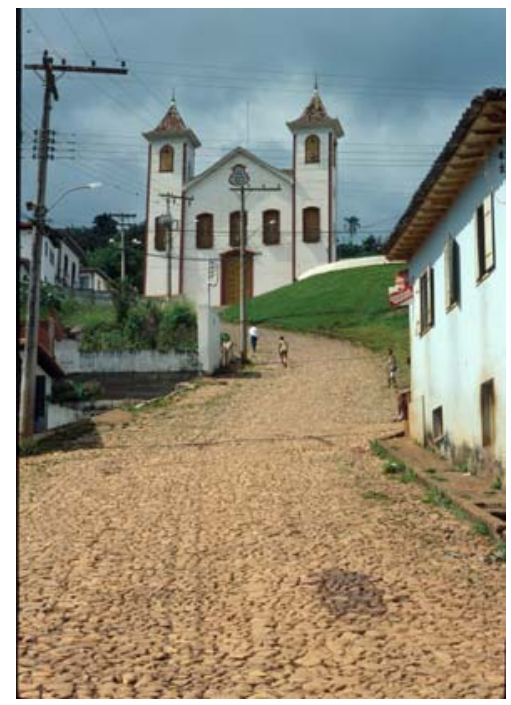



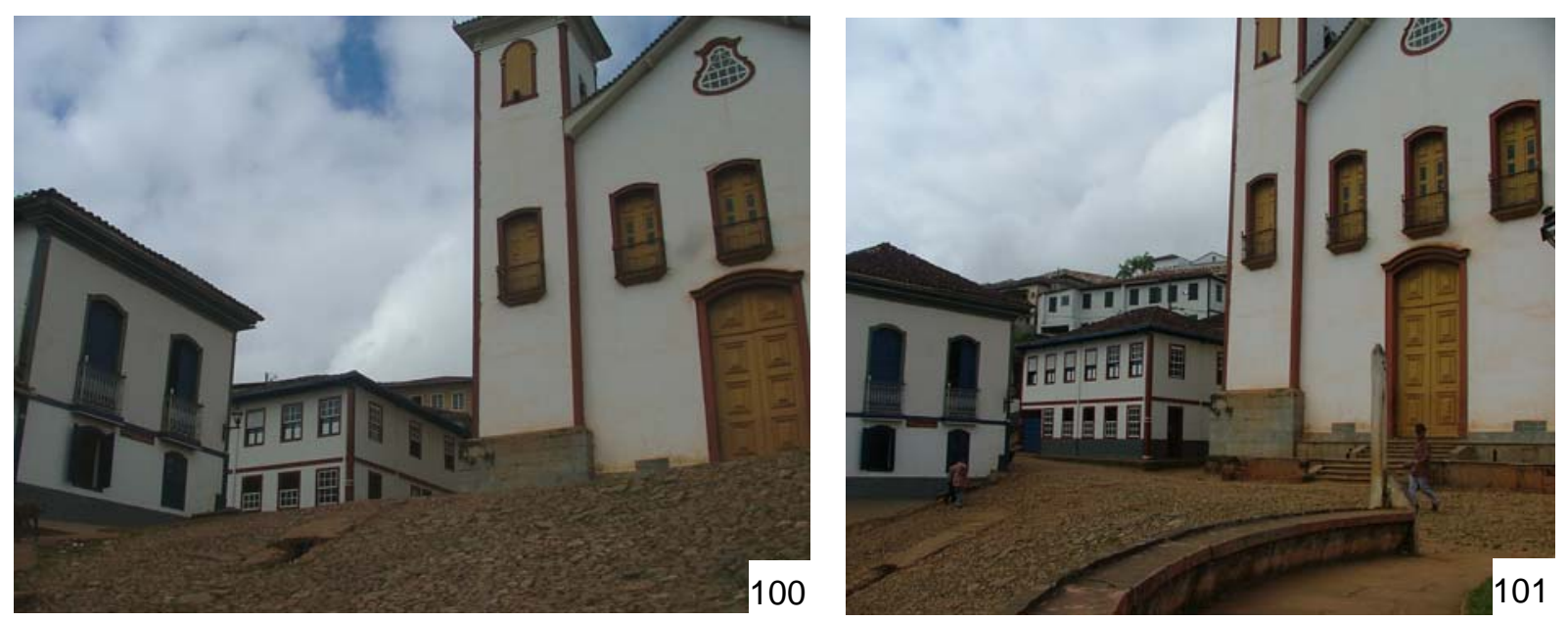

Figura 100 e Figura 101. Percepção da praça da Matriz (Praça Getulio Vargas) - acesso pela ladeira da Matriz, olhando para a esquerda
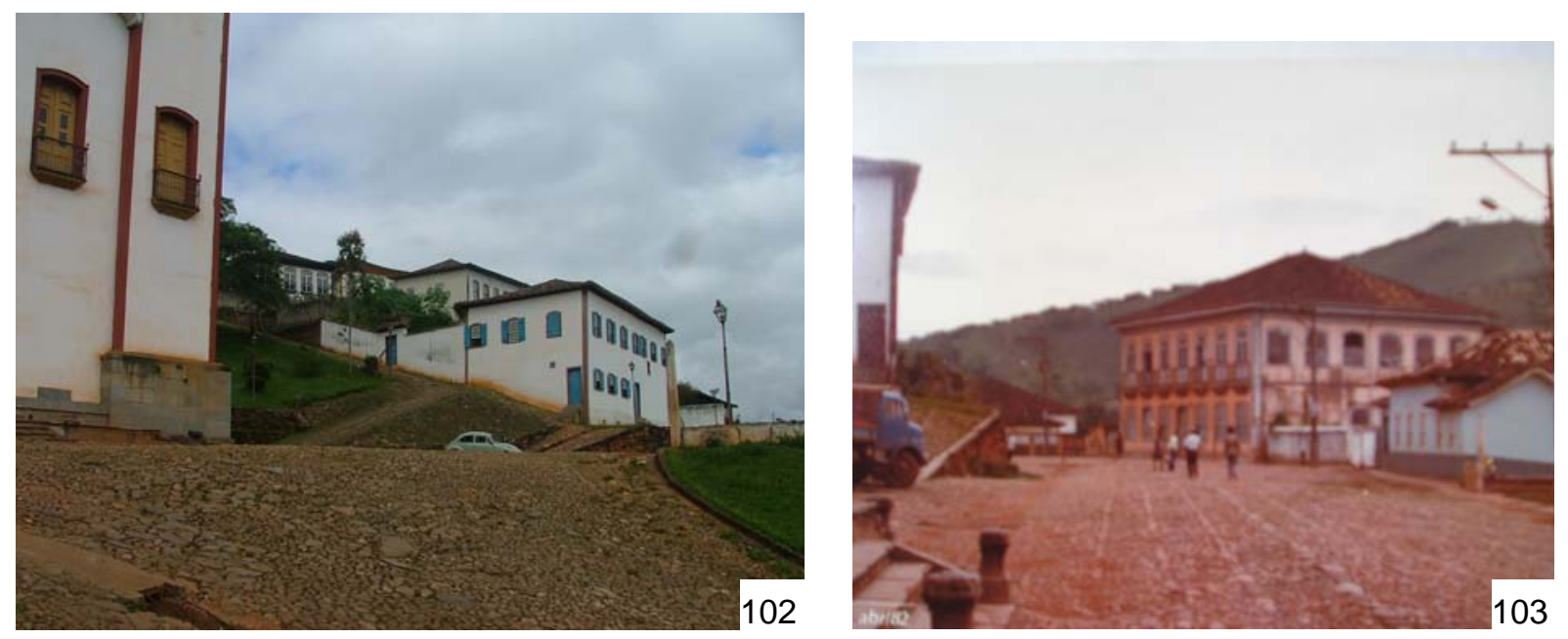

Figura 102 e Figura 103. Percepção da Praça da Matriz (praça Getulio Vargas). Acesso pela ladeira da Matriz, olhando para a direita. Fonte: IPHAN (2006)

Prosseguimos para ao próximo acesso à praça, outro caminho, pela rua Nelson de Senna, conforme a capacidade de compreensão apresentada a seguir. 


\section{A percepção da Praça Getúlio Vargas: a partir da rua Nelson de Senna}

Passando pela rua Nelson de Senna, percebe-se estar em via sinuosa, praticamente na mesma cota de nível, trazendo a sensação de estar caminhando no plano. O movimento de ondulação horizontal e levemente vertical que a via gera representa importante elemento de revelação da arquitetura, da espacialidade urbana que se mostra inédita a cada movimento de um lado a outro da rua (da Figura 106 à Figura 114). E por essa trajetória percebem-se ao longe as torres da igreja Matriz, quase que uma sobreposta a outra (Figura 106 à Figura 112).

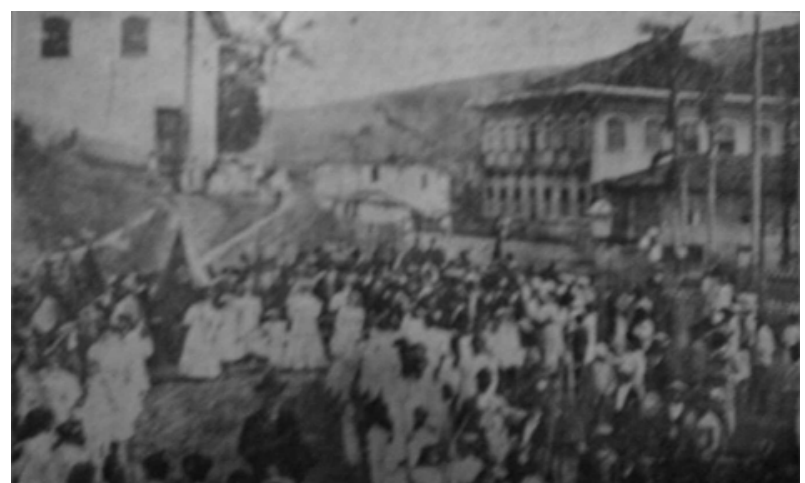

Figura 104. Praça da Matriz - Festa do Império do Divino

Fonte: IPHAN (2006)

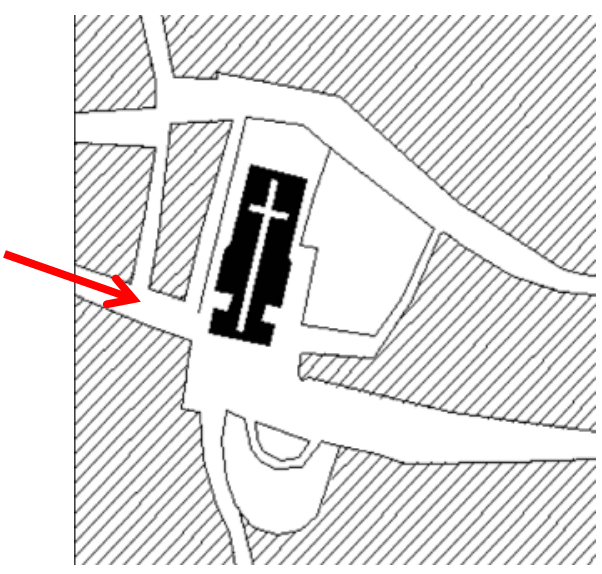

Figura 105. de indicação de acesso a praça Getúlio Vargas

A igreja se mostra tímida, aparentemente na mesma proporção que os casarões (Figura 106, 107 e Figura 108 à 110), mas à medida que nos aproximamos 
dela, há a descoberta e o impacto de sua presença em escala destacadamente superior às das demais edificações que nos direcionou a ela (Figura 111 e 112). Neste momento de aproximação não se imagina a presença de praça ou largo, pois o que se vê é a continuação da rua Nelson de Senna com sua sinuosidade característica, após a fachada principal da Matriz (Figura 112). Entretanto, quando já nos encontramos quase em frente à antiga Casa de Câmara, edificação modesta, é que percebemos a abertura de amplo largo, livre de qualquer obstáculo, ou elementos em seu centro (Figura 114). Ao se observar pela direita depara-se com a ladeira da Matriz e, ao longe, a igreja Bom Jesus do Matosinho. Imediatamente nos limites da praça, neste lado não há edificações, mas a sensação de espaço fechado se mantém pela forte presença da topografia, que se reflete em rebatimentos de encostas e morros, criando um espaço encerrado em si mesmo (Figura 95 e Figura 226, 227).
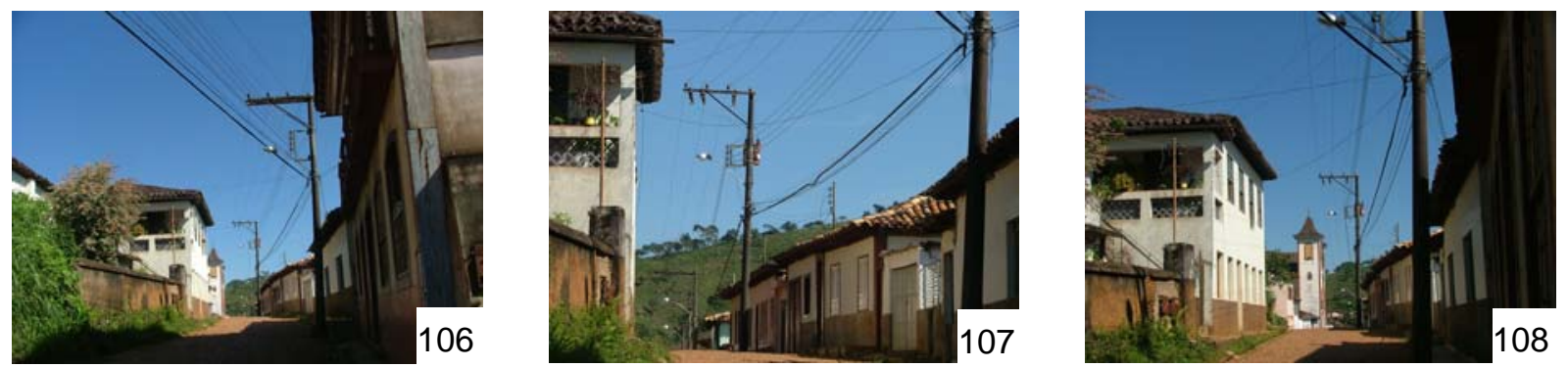

Figura 106, 107, 108. Praça da Matriz - percebida pela rua Nelson de Senna
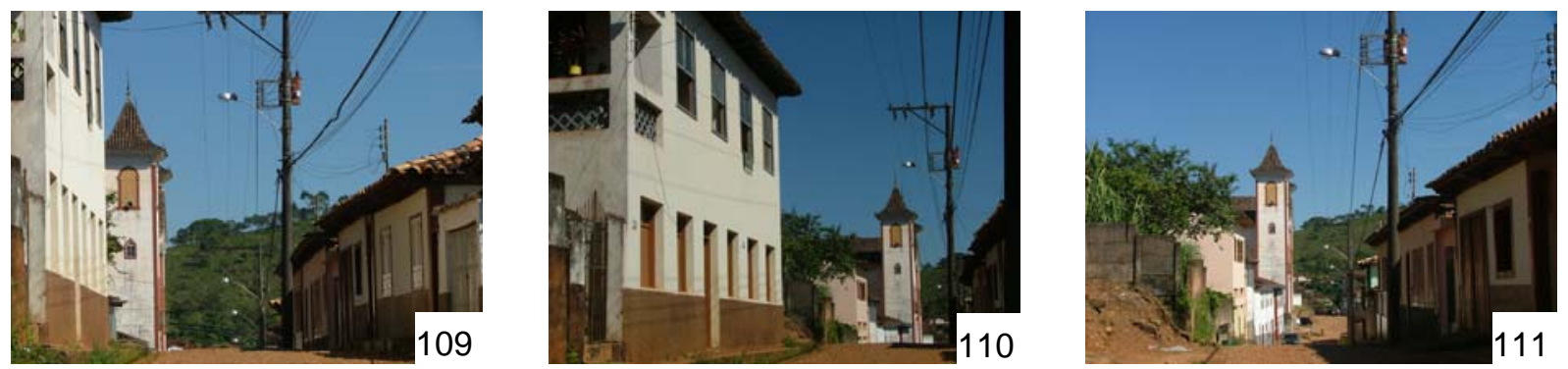

Figura 109, 110, 111. Praça da Matriz - percebida pela rua Nelson de Senna 

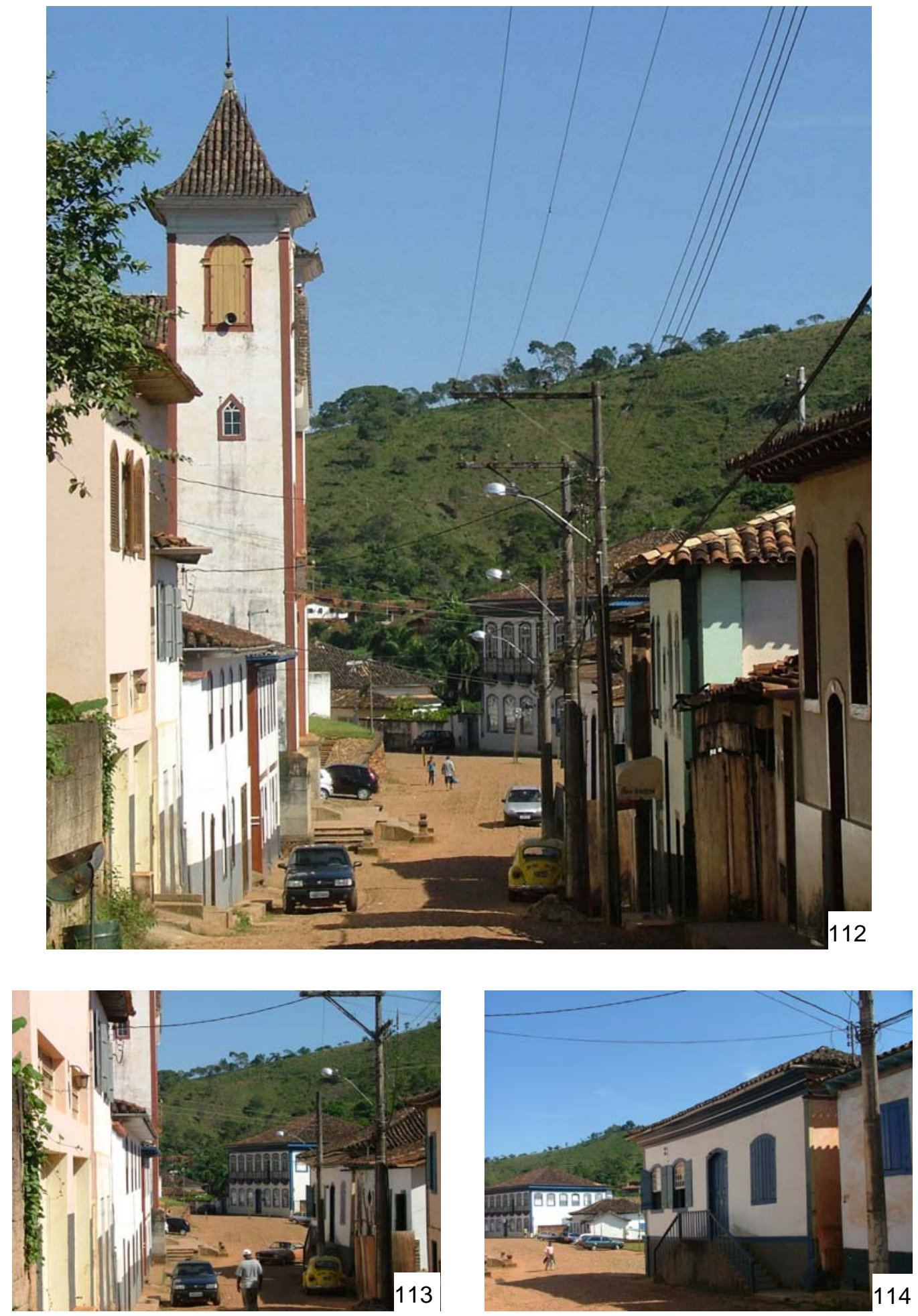

Figura 112. Figura 113. Figura 114. Praça da Matriz percebida a partir da rua Nelson de Senna 


\section{Direita}
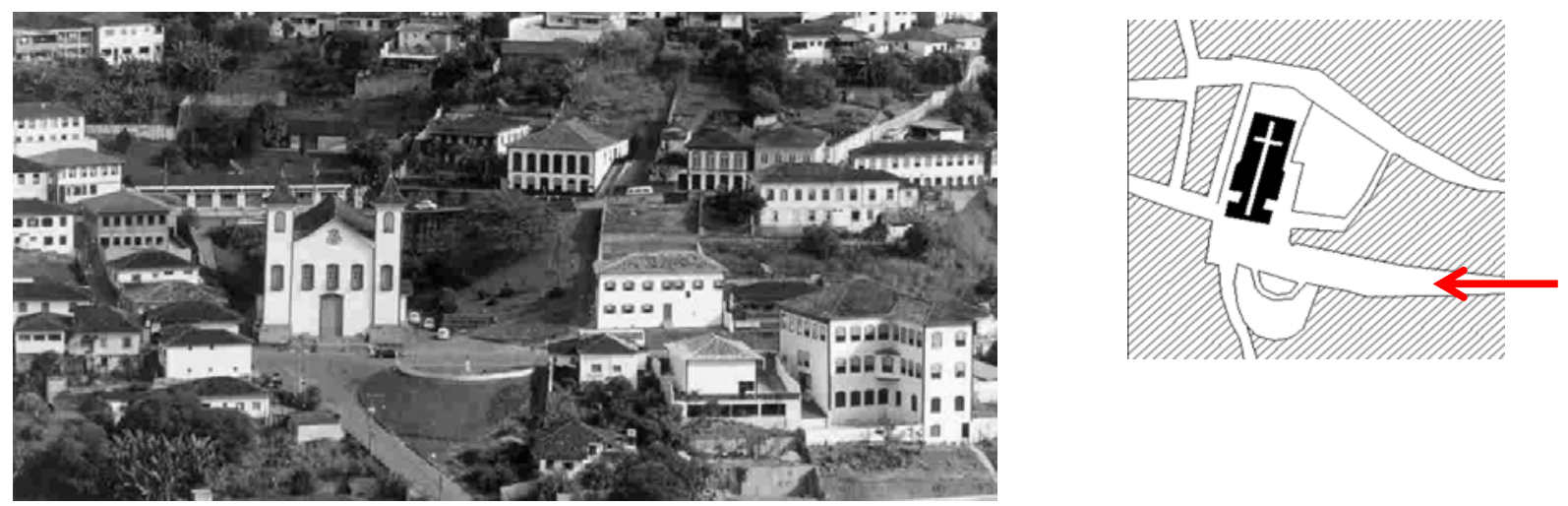

Figura 115. Praça da Matriz - acesso pela antiga rua Direita e Figura 116. Mapa de acesso à praça

Ao aproximarmos da praça Getúlio Vargas, pela antiga rua Direita, a princípio vislumbramos apenas uma via estreita e sinuosa (Figura 117). Ma, em seguida, ela se abre amplamente e descobrimos um grande largo (Figura 118). Uma praça surge do alargamento desta via e é emoldurada pelo casario e topografia que a envolvem, (Figura 118, Figura 119), como um "fim de linha", tendo como edificação principal a antiga Casa de Câmara (em sua modesta escala). Surgem como em um encontro final de confluência, onde todos possam estar juntos, um grande salão, uma praça fechada. 

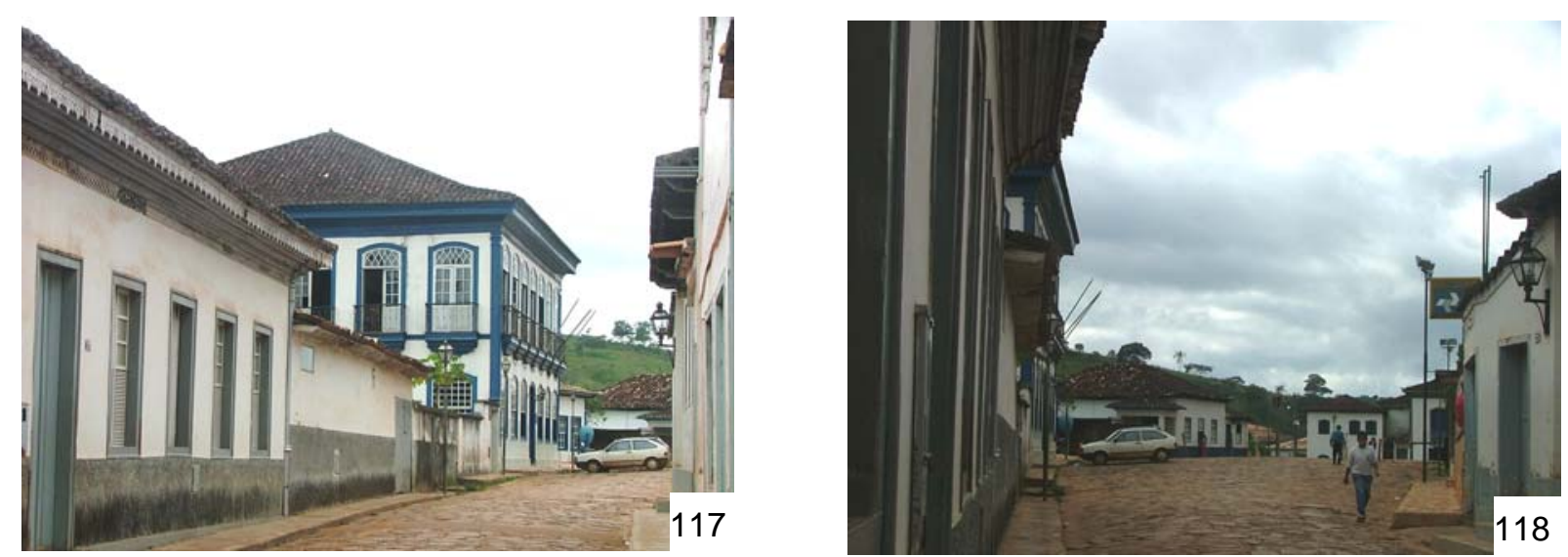

Figura 117 e 118. Praça da Matriz - acesso pela antiga rua Direita

Entretanto, à direita percebe-se a presença marcante da igreja Matriz (Figura 120), e, firmando o olhar nesta direção, constatamos que a antiga rua Direta e rua $p$ Getúlio Vargas, que se encerra nesta direção pelo casario e nível topográfico da própria via que se torna mais elevado ao se afastar da praça em sentido à rua Nelson de Senna (Figura 120, Figura 121).
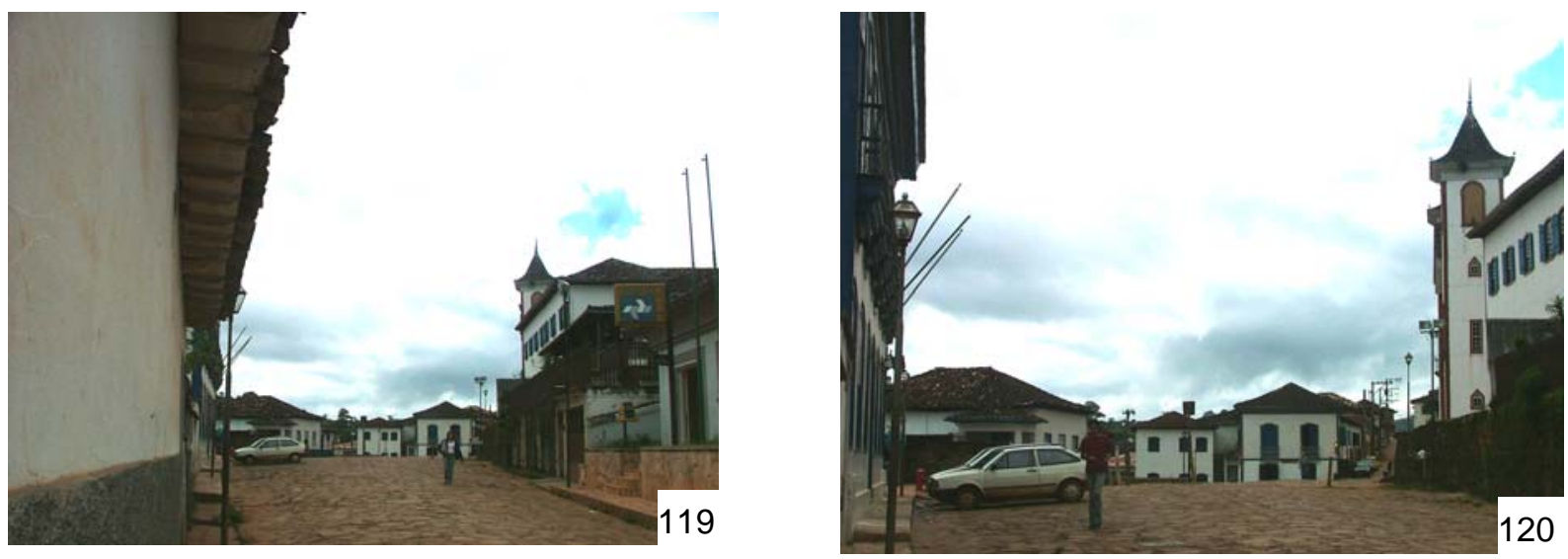

Figura 119, 120. Praça da Matriz - acesso pela antiga rua Direita 

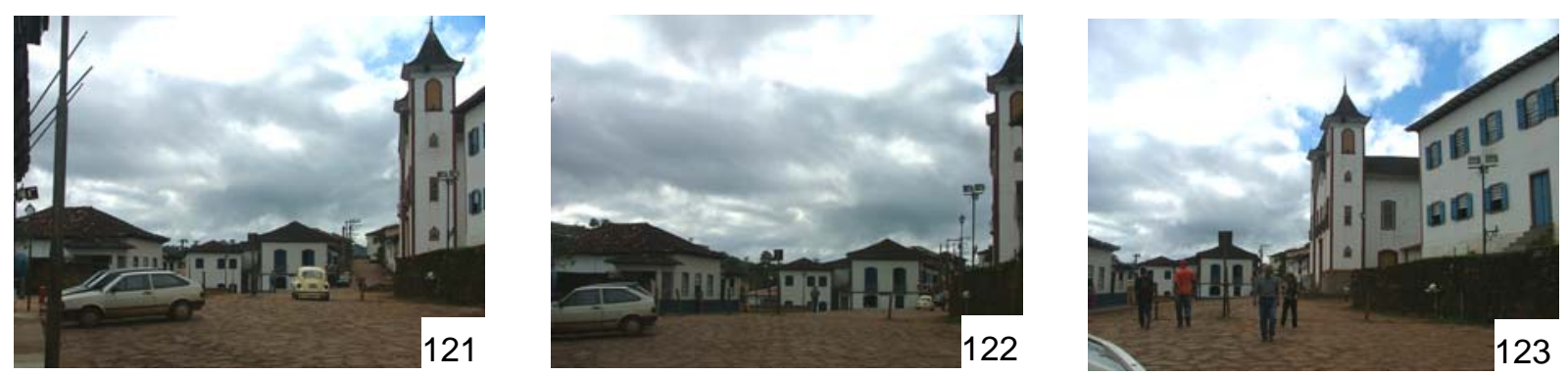

Figura 121, 122, 123. Praça da Matriz - acesso pela antiga rua Direita

Após entrada definitiva na praça Getúlio Vargas, à esquerda, nos deparamos com o ponto do antigo Pelourinho, que é emoldurado por uma colina, morro elevado que se mostra como uma tangente à praça, consolidando seu fechamento (Figura 125).
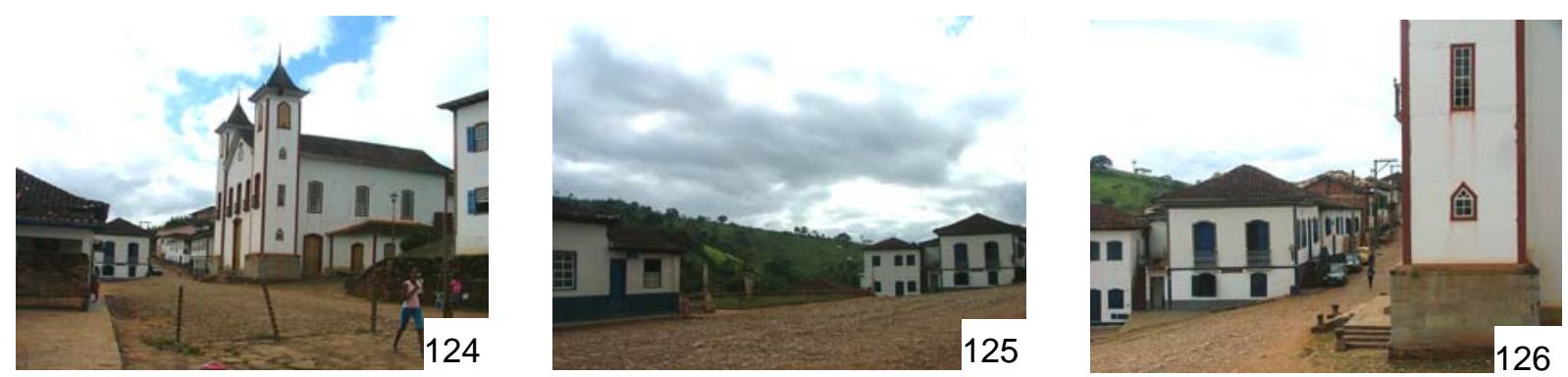

Figura 124, 125, 126. Praça da Matriz - acesso pela antiga rua Direita

Nesta leitura do espaço perspéctico que conduz à praça Getúlio Vargas, percebemos que ocorrem lacunas por perda de edificações que ruíram ou foram demolidas, gerando descontinuidade na linha de percepção do espaço que nos direciona à praça. É como algum tipo de ruído visual que não deveria existir, tais como as edificações eliminadas na rua Nelson de Senna (Figura 77, Figura 111), 
que comprometem a trajetória de apreensão e descoberta da igreja Matriz e sua praça, assim como a demolição do passadiço do antigo colégio de Nossa Senhora da Conceição na ladeira da Matriz, que representa a supressão de uma importante interrupção da linha de visada, que colaborava para o encerramento e emolduramento da igreja Matriz e da praça Getúlio Vargas quando percebida pelo transeunte de origem do vale, do córrego Quatro Vinténs, e ribeirão do Lucas (Figura 93 e 98). Identificamos ainda o nivelamento de parte da praça, no local do antigo Pelourinho, traduzindo certa geometrização do espaço e indicação de construção da edificação térrea em parte da área que tradicionalmente pertencia à praça (Figura 69).

Após a percepção espacial da praça Getúlio Vargas, buscando a compreensão de seus princípios artísticos de acordo com Camillo Sitte (1992), reconhecemos que é difícil distinguir os limites explorados beneficamente pelas praças irregulares. Entretanto, no caso desta praça, tivemos a oportunidade de descobrir, notar, identificar os seguintes princípios artísticos indicados por Camillo Sitte (1992) em seus estudos, conforme entendimentos apontados no capítulo primeiro desta pesquisa:

- Praça do tipo larga;

- Dominada pela fachada da Matriz.;

- Fácil percepção da edificação mais importante (sua forma/ dimensão/ ornamentação figurativa); 
- Praça formada por amplo espaço livre (sem monumentos ornamentais em seu centro);

- A Igreja Matriz é o componente básico (apesar da importância da edificação da Câmara, que é bem modesta em escala e valoração arquitetônica);

- A construção da Igreja é "entalada" em talude e não é geminada a outras edificações;

- Praça que pode ser entendida como fechada, se considerarmos, além da arquitetura, o emolduramento pelos morros que a cercam.

Acreditamos que este entendimento sobre a importância da topografia na artisticidade do ambiente possa ser reforçado pela afirmação de Charre (1990 p.221).

In questo caso il ruolo accordato all'estetica non se limita all'arredo urbano, né allá decorazione delle facciate, ma investe l'elaborazione dell'intera organizzazione topográfica.

Destacamos, por serem de relevância, as transformações ocorridas na praça Getúlio Vargas, desde o tombamento da cidade pelo IPHAN: a redução de sua área tradicional por inserção de nova arquitetura, a construção de "platô" onde ficava o pelourinho e a eliminação do passadiço da ladeira da Matriz. 


\section{PRAÇA JOÃO PINHEIRO, praça da Prefeitura}

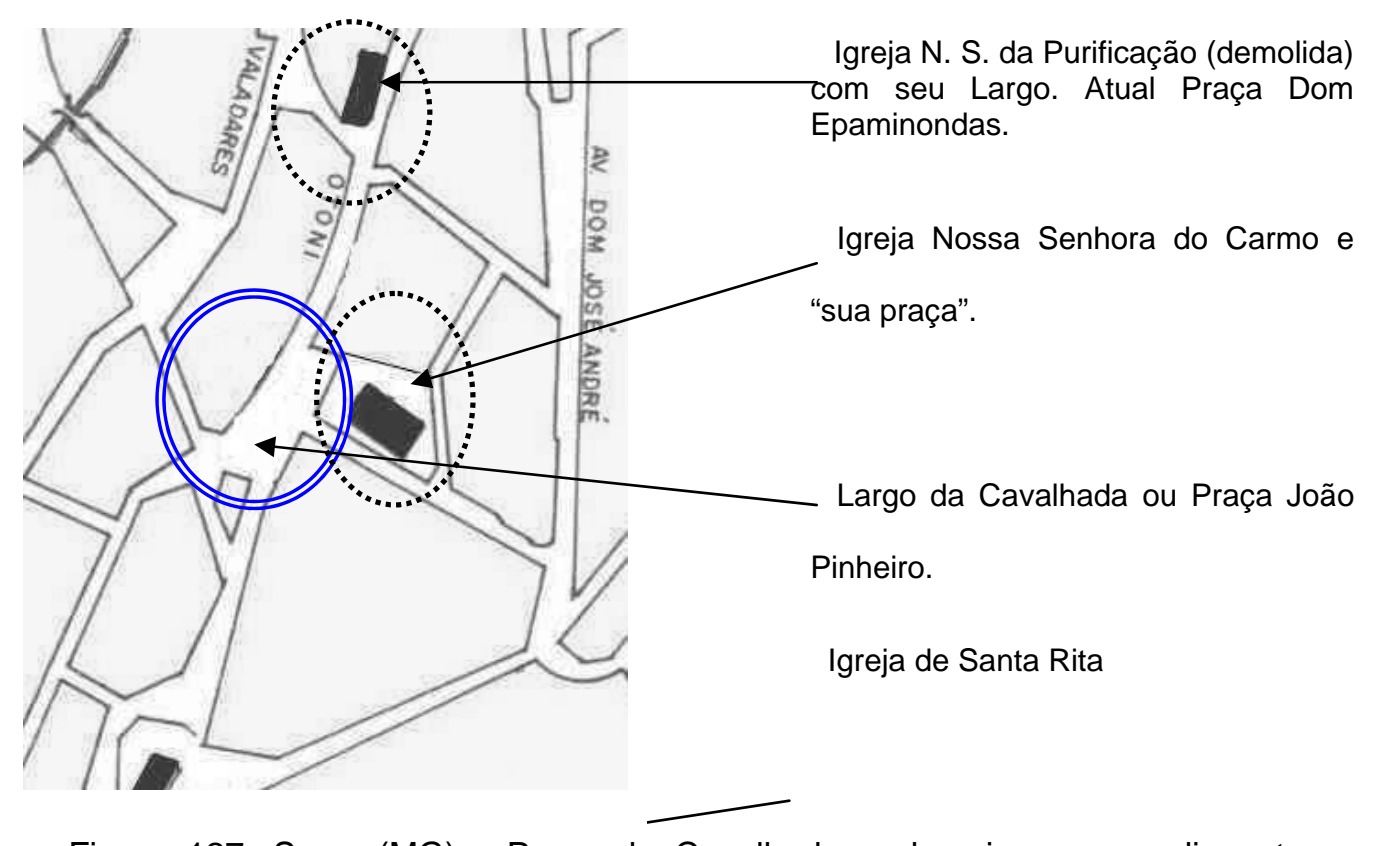

Figura 127.: Serro (MG) - Praça da Cavalhada e demais praças adjacentes. Fớnte: adụ̂tado de (FUNDAÇÃO JOÃO PINHEIRO 1994)

A praça João Pinheiro é ressaltada no universo urbano de Serro, dentre inúmeros fatores, pela sua condição de destaque no tecido figurativo da cidade. Recebe a confluência direta dos movimentos de circulação entre a igreja Nossa Senhora do Carmo, igreja Santa Rita e antiga igreja Nossa Senhora da Purificação hoje praça Dom Epaminondas - (Figura 127), representando importante espaço público de encontro entre pessoas e manifestações culturais diversas (Figura 129, Figura 131). Passou por transformações morfológicas expressivas ao longo do século XX, que resultaram em uma nova configuração e maneira de apropriação do 
espaço. Entretanto, sua condição espacial de principal praça de lazer e manifestação social em Serro permanece.

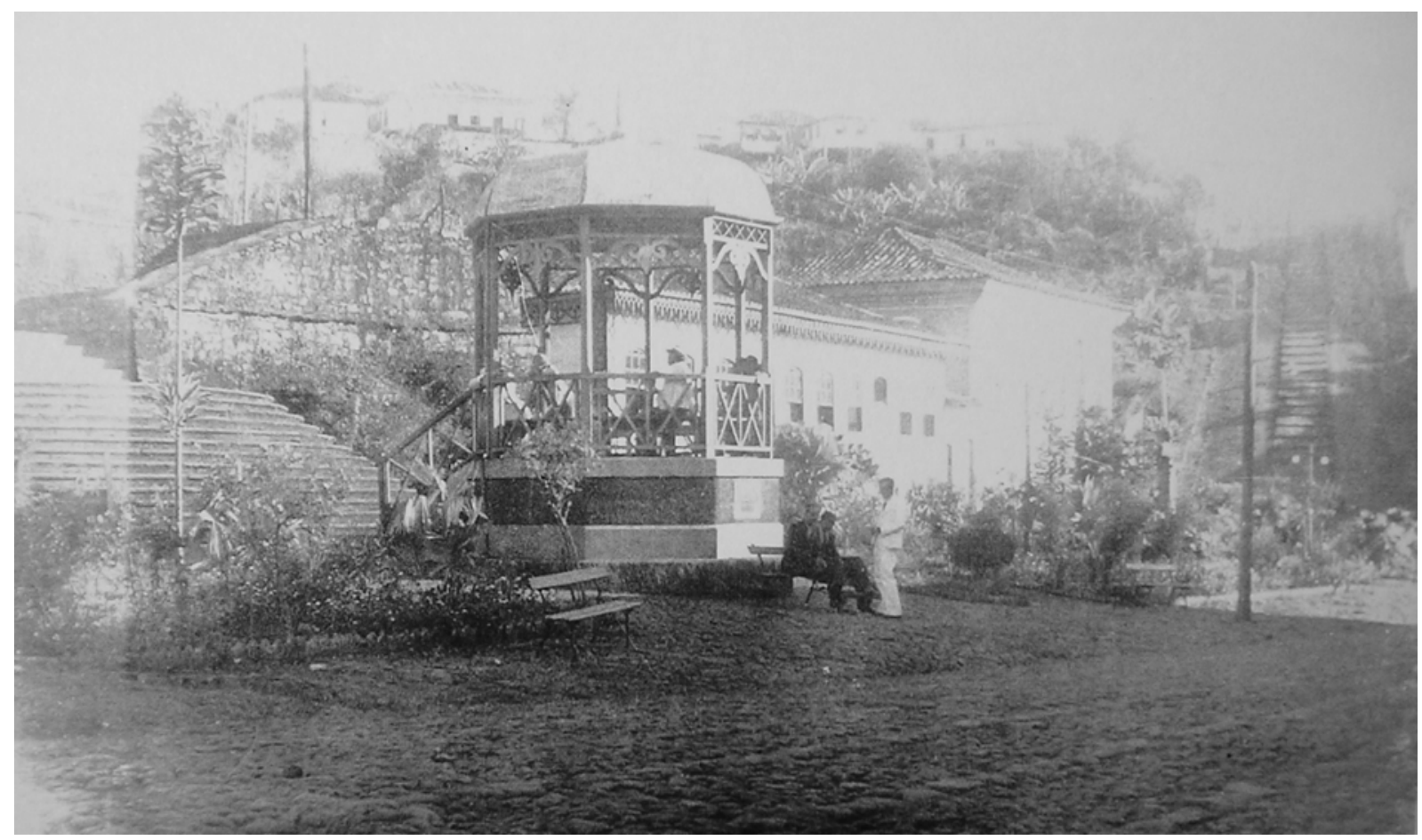

Figura 128. Praça João Pinheiro, ainda como largo da Cavalhada - escadaria do Carmo e escadaria de Santa Rita

Fonte: IPHAN (2006)
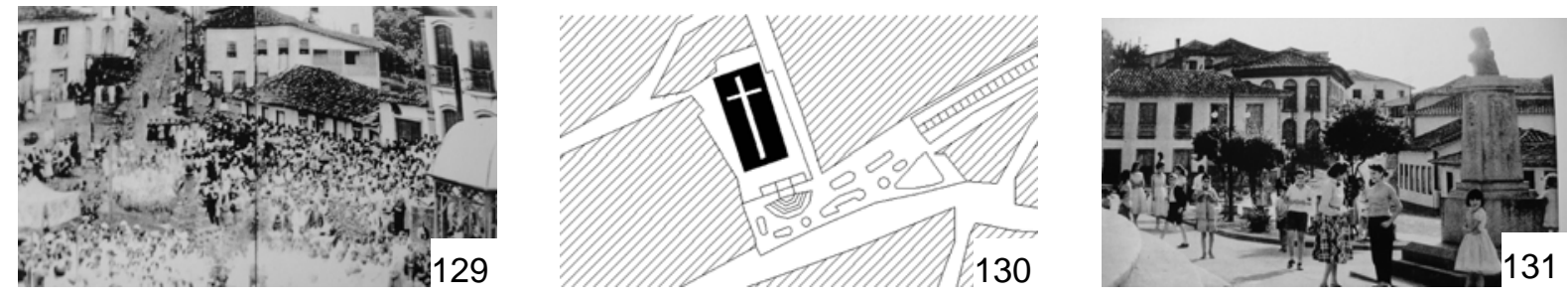

Figura 129, 130, 131. Praça João Pinheiro Fonte: IPHAN (2006)

A imagem da praça com o coreto e jardins reflete adequação do final do século XIX e início do século XX (Figura 128), uma vez que sua origem setecentista remete a amplo terreiro. Mas, com este desenho, ainda mantinha a apropriação ininterrupta do espaço, do piso, percebido a partir da pavimentação e cotas de nível, 
que foram radicalmente alterados na década de 1940 (Figura 162 a 165 e Figura 166). Ao observamos a praça João Pinheiro em planta baixa ou através de uma perspectiva mais ampla verificamos que a ela estão ligados diretamente por escadarias o largo da igreja de Nossa Senhora do Carmo, e também o largo da igreja Santa Rita, indicando a presença de praças seqüenciadas - mesmo que atualmente ocorra ocupação margeando a escadaria de Santa Rita - (Figura 133). Contudo, se nos ativermos apenas ao largo do Carmo e à Praça João Pinheiro, acreditamos não haver dúvidas quanto à continuidade das duas praças definidas pela mesma arquitetura monumental, uma única igreja, a de Nossa Senhora do Carmo (Figura 132).

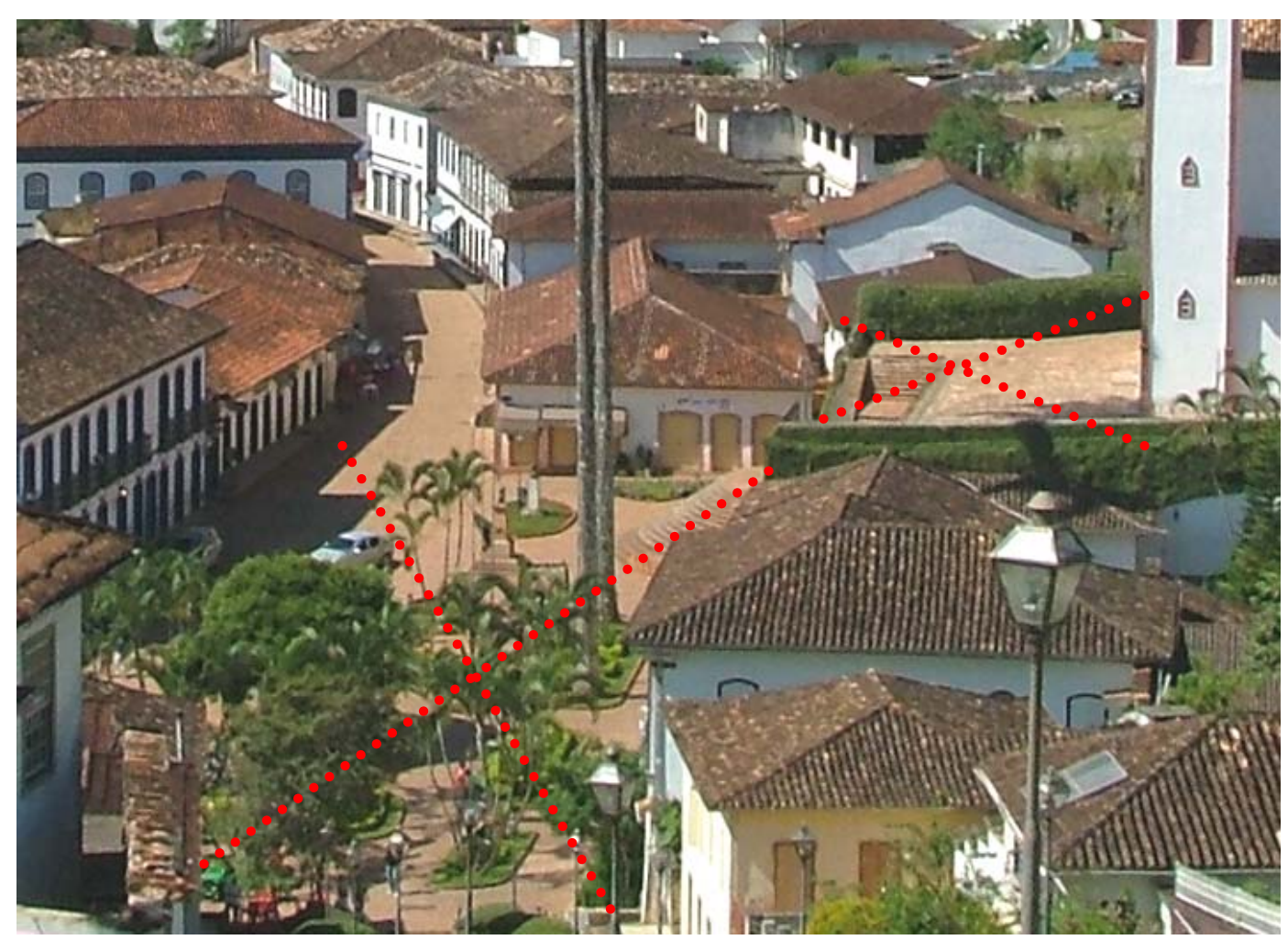

Figura 132. Praça João Pinheiro e largo da igreja Nossa Senhora do Carmo. 
Importa, ainda, destacar que do largo da igreja Santa Rita vislumbramos a igreja do Carmo e a igreja Nossa Senhora da Purificação (se não tivesse sido demolida), com suas fachadas principais voltadas para a praça João Pinheiro, direcionando o fluxo, o movimento, o olhar para o "Largo da Cavalhada" - atual praça João Pinheiro - inclusive para a própria Igreja Santa Rita (Figura 133).

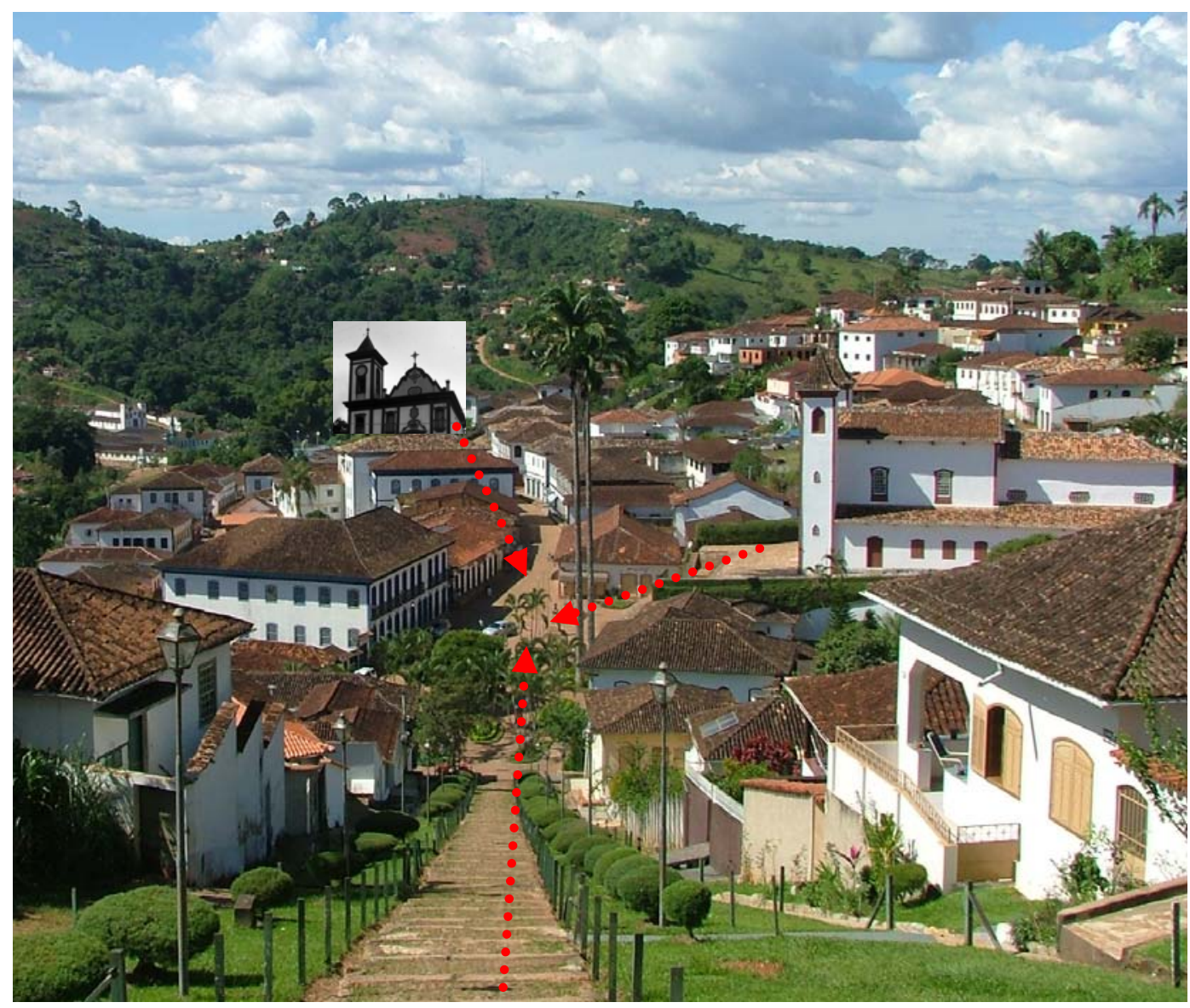

Figura 133. Praça João Pinheiro - ligação entre a Igreja Santa Rita, Nossa Senhora do Carmo e a antiga igreja da Purificação (simulação).

Entendemos que a ligação entre a Igreja de Nossa Senhora do Carmo e Santa Rita à praça João Pinheiro é direta, uma vez que as escadarias de acesso ao 
largo de ambas nascem nesta praça (Figura 82, Figura 128, Figura 133). A partir desta realidade, apresentaremos a percepção da praça pelos seus principais caminhos de acessos: rua Fernando Vasconcellos - umas das mais antigas vias de chegada à cidade (Figura 172), rua Dr. Antônio Honório Pires - via de ligação entre a igreja Matriz, o "largo da Purificação" hoje praça Dom Epaminondas à praça João Pinheiro (Figura 148) e Travessa Magalhães - ligação direta entre a parte baixa da cidade, onde hoje estão a rodoviária e a área historicamente mais nobre e elevada da cidade setecentista, representando caminho direto para a igreja Santa Rita (Figura 183).

Consideramos o acesso entre a igreja Nossa Senhora do Carmo e a de Santa Rita como relações diretas com a praça João Pinheiro; acreditamos que a interdependência entre esses ambientes ocorra a partir de uma concepção imediata e ao mesmo tempo surpreendente,o que nos condiciona a uma percepção distinta diante dos demais caminhos investigados para a compreensão da praça João Pinheiro.

$\underline{\text { Relação de proximidade entre a Praça João Pinheiro e o largo da Igreja de Nossa }}$ Senhora do Carmo

A relação entre a igreja de Nossa Senhora do Carmo e praça João Pinheiro é contínua (Figura 132); a igreja pertence ao conjunto que configura a praça, mesmo 
tendo seu largo, "sua própria praça" em patamar superior. Uma praça é a extensão da outra, possibilitando um vínculo que nos apresenta os dois espaços como se estivessem compreendidos numa situação de causa e reciprocidade. Podemos, ainda, perceber a especial condição que liga os valores dos dois ambientes no domínio de "um único".
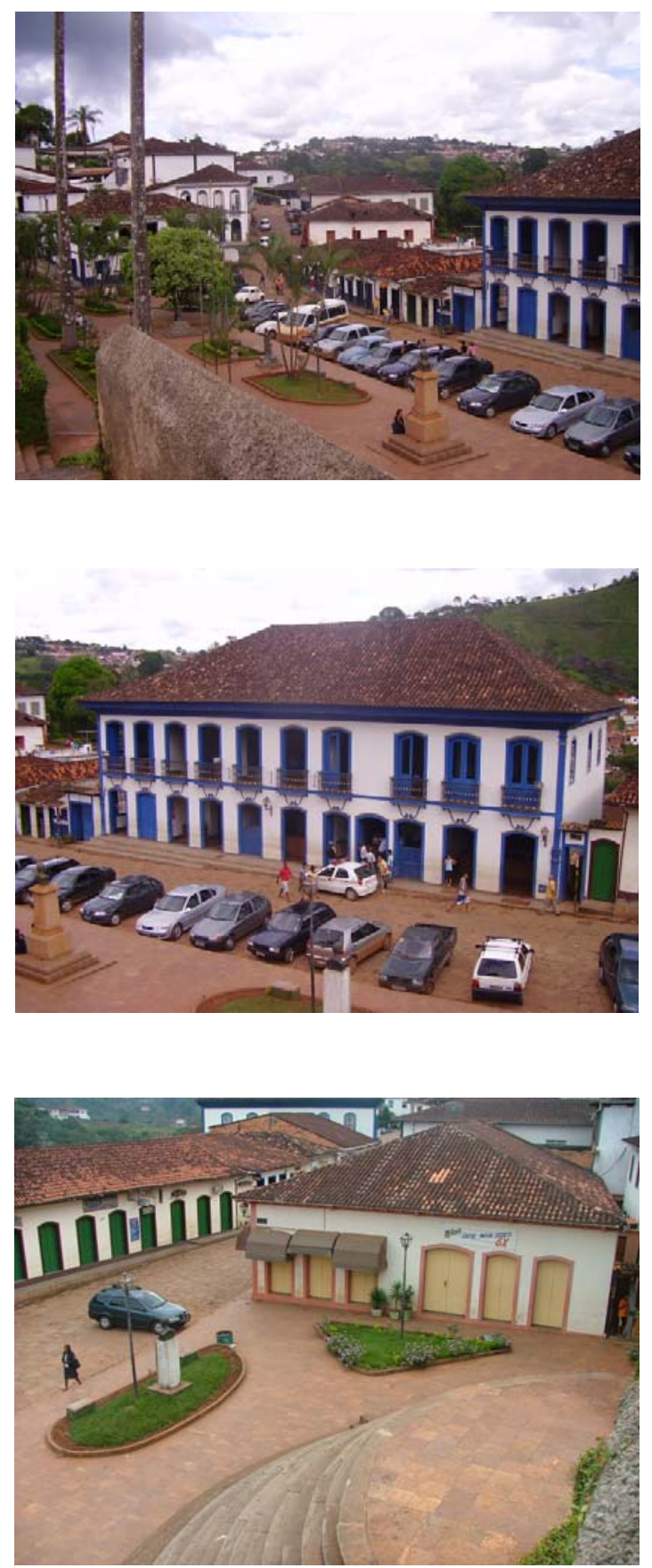

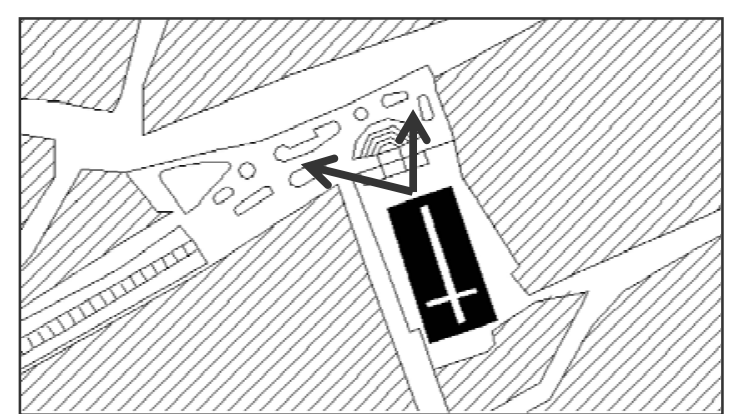

Figura 134. Praça João Pinheiro - mapa da praça e da posição do observador.

Figura 135. Praça João Pinheiro - casario no sentido rua Fernando Vasconcellos.

Figura 136. Praça João Pinheiro - sede da Prefeitura.

Figura 137. Praça João Pinheiro - casario no sentido rua Antônio Honório Pires. 
Para aquele que se localiza no topo da escadaria da igreja Nossa Senhora do Carmo (Figura 134), a praça João Pinheiro se apresenta absolutamente encerrada em um ambiente fechado pelo casario e colinas - 0 ambiente natural que a envolve - contribuindo para uma percepção de espaço coeso (Figura 135 à Figura 137). E, nessa perspectiva o sobrado da prefeitura, com sua expressiva escala arquitetônica, se coloca por meio de proporções absolutas, como edificação dominante diante da praça João Pinheiro.

Entretanto, para aquele que se posiciona diante do edifício da prefeitura, a igreja de Nossa Senhora do Carmo, se torna quase "onipresente". Em sua posição de palco, faz do "resto" da praça mera platéia diante de seu forte domínio e impacto na paisagem e composição de todo o conjunto. As dimensões de sua arquitetura, simples, de linhas retas, ressaltam sua monumentalidade, marcada pelas proporções em relação às da praça João Pinheiro (Figura 138 à Figura 140). Mesmo em alguns pontos, com vegetação comprometendo a sua conexão com o observador, ela se impõe. Entretanto, do ponto de vista daquele que acessa a praça pela rua Antônio Pires, a igreja do Carmo, apesar das dimensões arquitetônicas, divide a atenção com a igreja Santa Rita, que, mesmo com uma escala arquitetônica diminuta, se destaca pela especificidade de sua implantação, não somente diante da praça João Pinheiro, mas também (Figura 164, Figura 167) diante da cidade de Serro. 


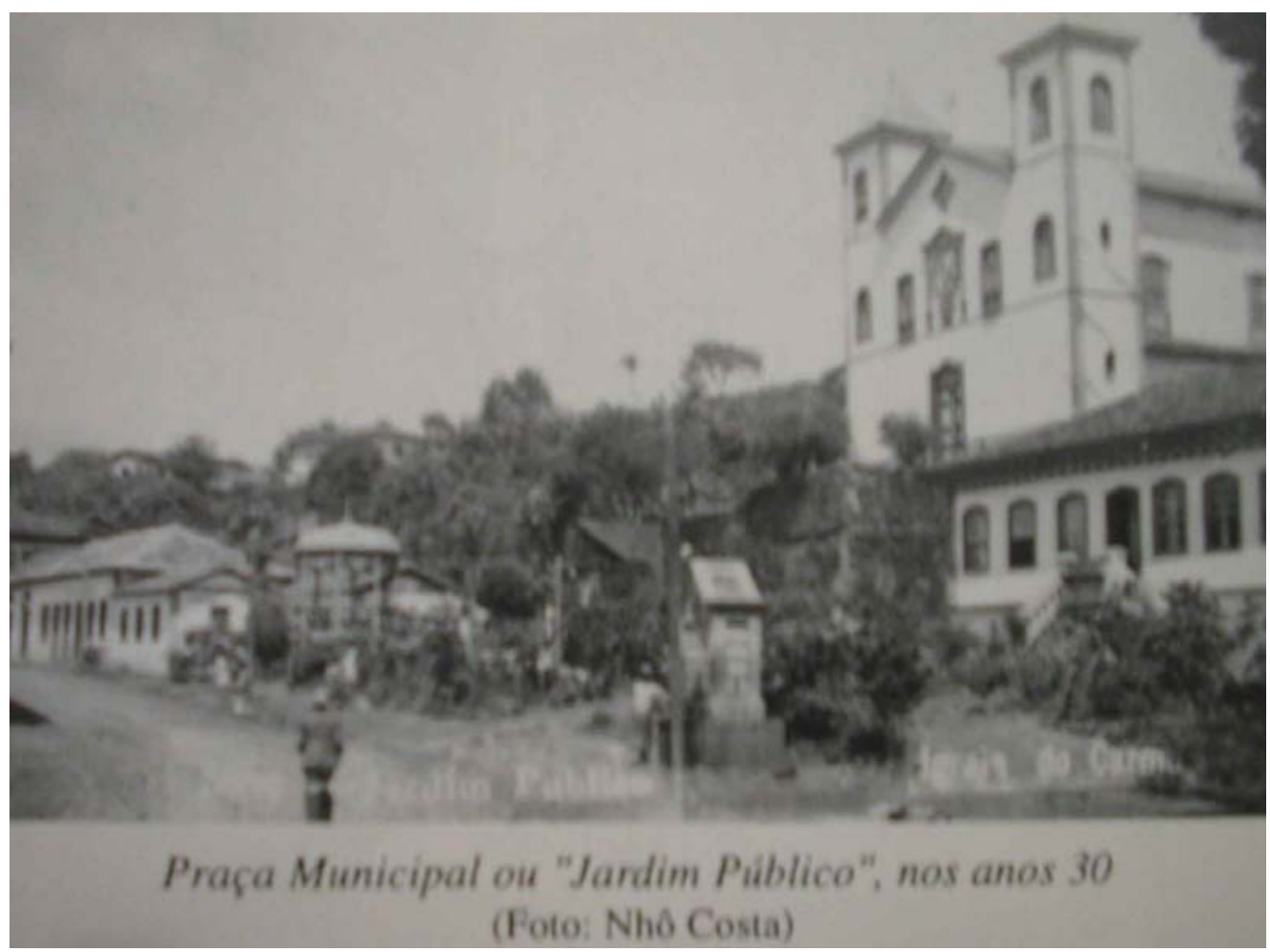

Figura 138. Praça João Pinheiro e igreja Nossa Senhora do Carmo. Fonte: IPHAN (2006)
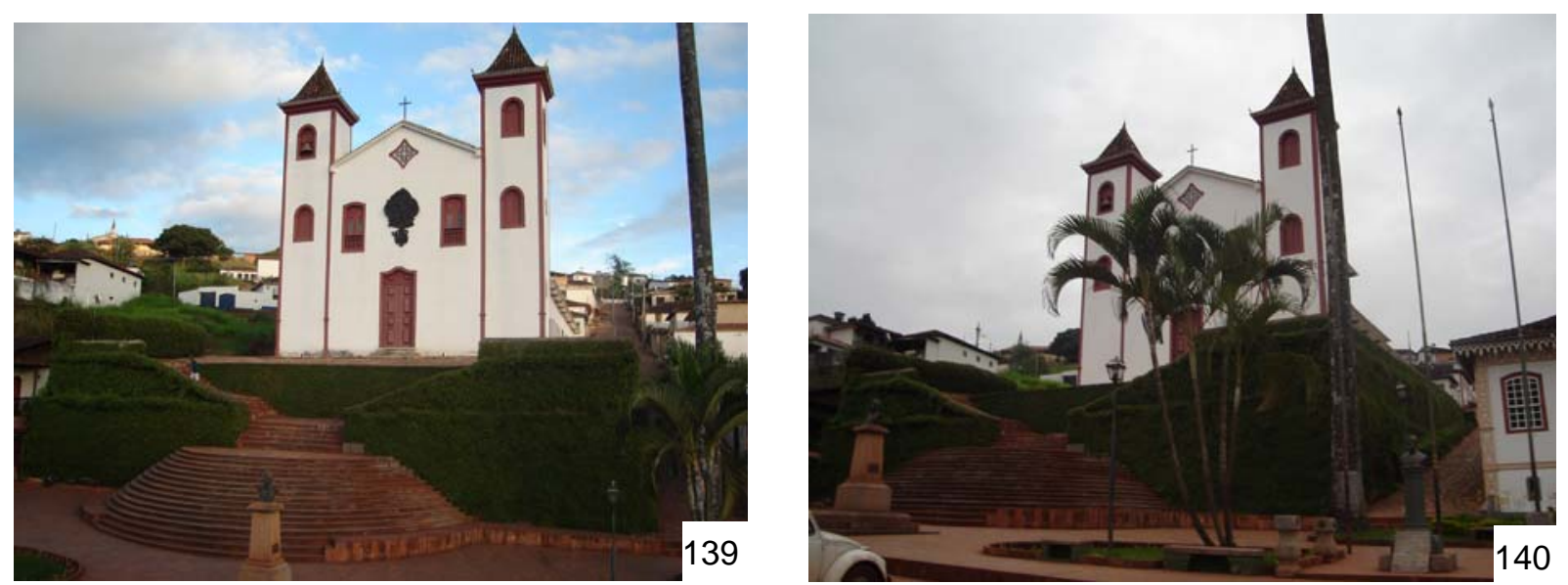

Figura 139, 140. Praça João Pinheiro e igreja Nossa Senhora do Carmo. 
$\underline{\text { Relação de proximidade entre a Praça João Pinheiro e Largo da Igreja Santa Rita }}$

A escadaria de acesso à Igreja Santa Rita surge na praça João Pinheiro como forte eixo que direciona o olhar e o movimento (Figura 141 à Figura 143). Devido à implantação (Figura 144) no topo da colina que faz parte da delimitação da praça João Pinheiro e define a ocupação da cidade de Serro, a igreja Santa Rita se coloca como um importante marco urbano, representando elemento de referência por toda a cidade de Serro.
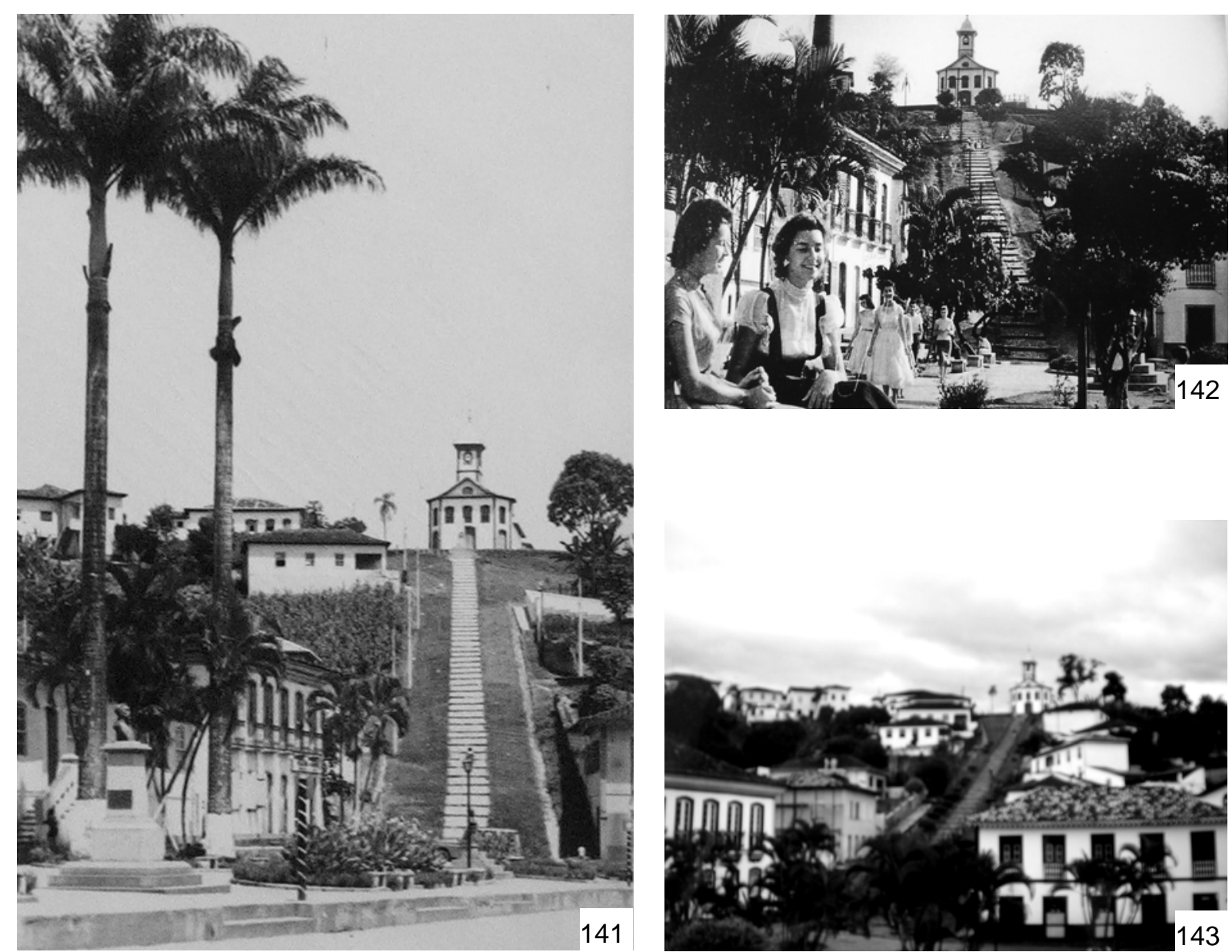

Figura 141, 142, 143. Praça João Pinheiro e Igreja Santa Rita Fonte: EA UFMG (2006) LAFODOC 
A partir do largo da igreja Santa Rita, temos uma vista panorâmica da cidade, centrada pela praça João Pinheiro e delimitada pela Igreja Bom Jesus do Matosinho em plano bem distante, e que se encerra na topografia, que é a principal responsável pela delimitação do ambiente construído da cidade (Figura 145).

Estando no largo da Igreja Santa Rita, percebemos com maior clareza a relação espacial entre o largo da igreja de Nossa Senhora do Carmo, e a praça João Pinheiro fazendo com que o espaço por eles configurado (Figura 132) represente, juntamente com a atual praça Dom Epaminondas, antigo largo da igreja da Purificação, a platéia do palco que representa a igreja Santa Rita (Figura 133 e 146). Trata da expressão máxima do barroco urbano em Serro.
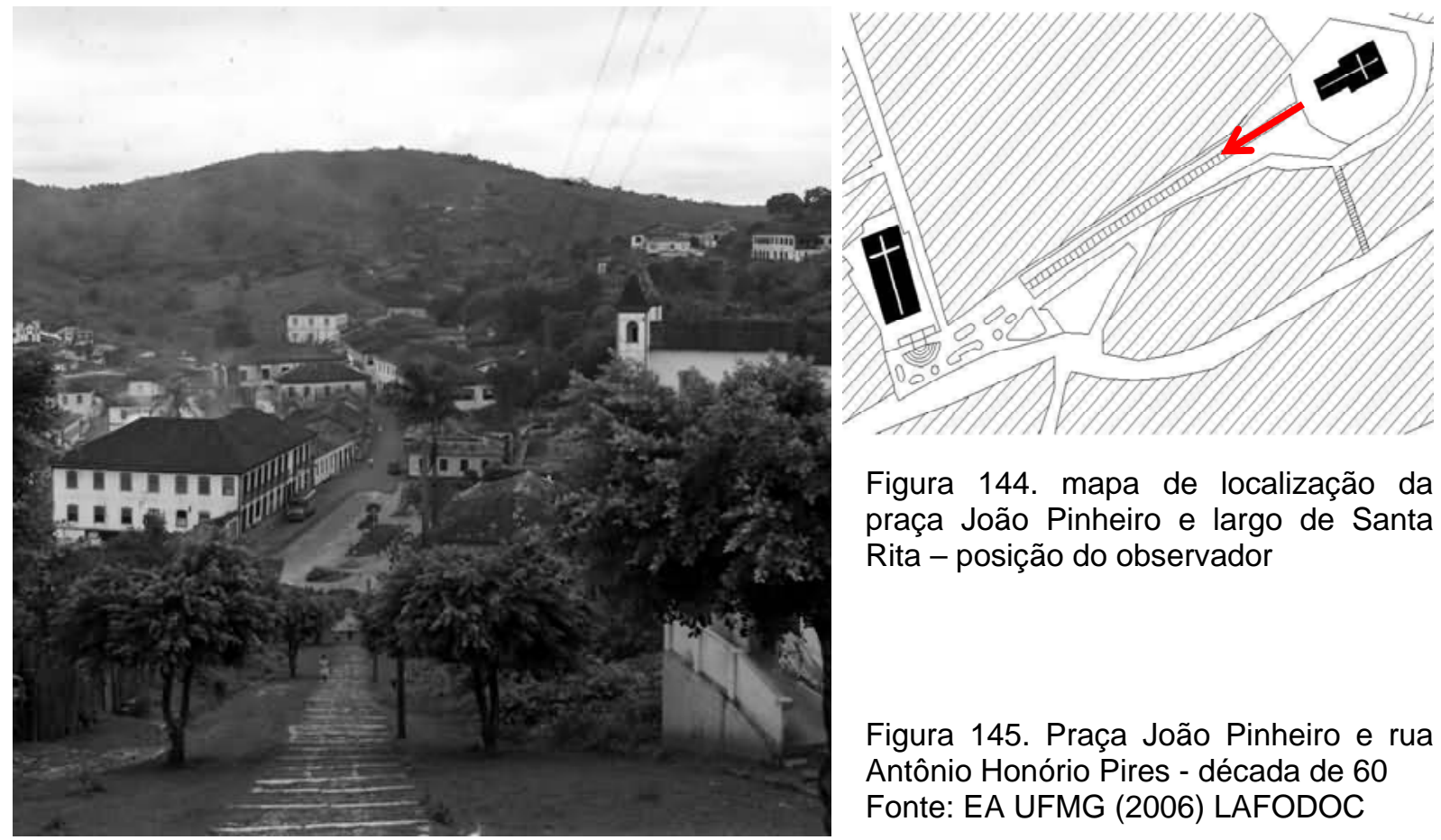

Figura 144. mapa de localização da praça João Pinheiro e largo de Santa Rita - posição do observador

Figura 145. Praça João Pinheiro e rua Antônio Honório Pires - década de 60 Fonte: EA UFMG (2006) LAFODOC 

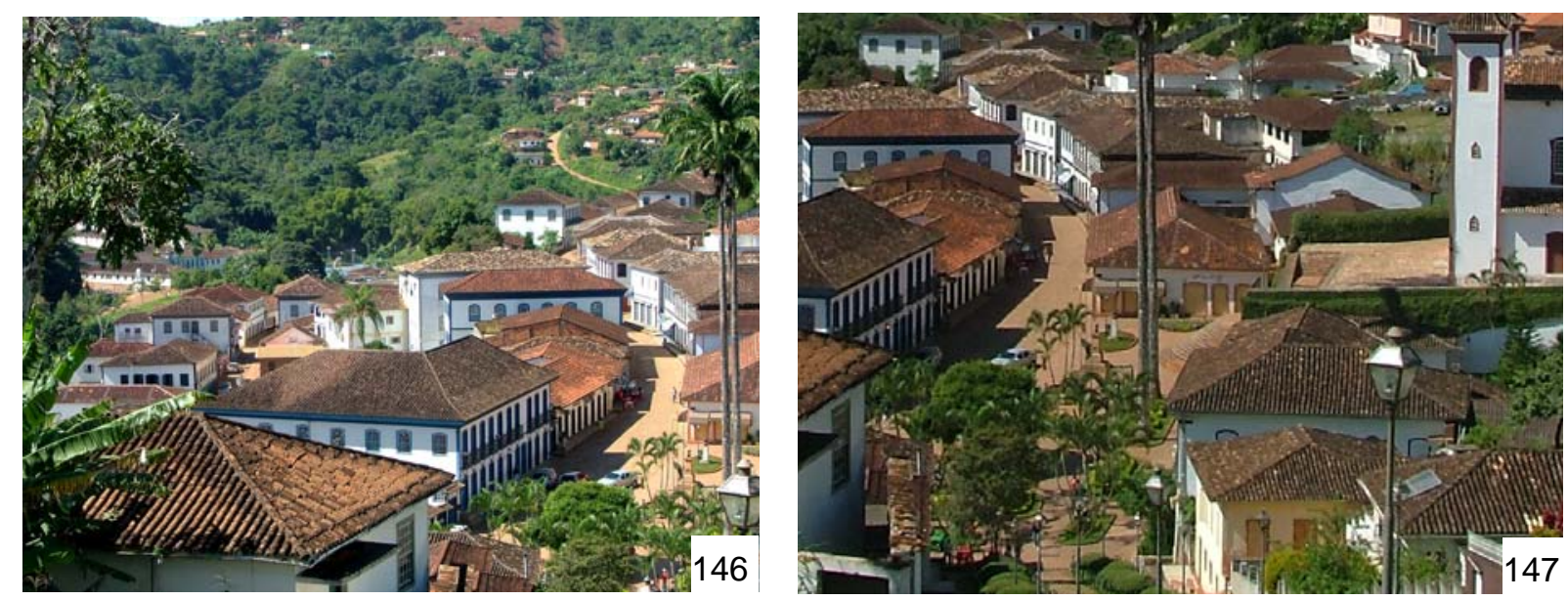

Figura 146. Figura 147. Praça João Pinheiro e rua Antônio Honório Pires // casario.

\section{A percepção da praça João Pinheiro: a partir da rua Antônio Honório Pires}

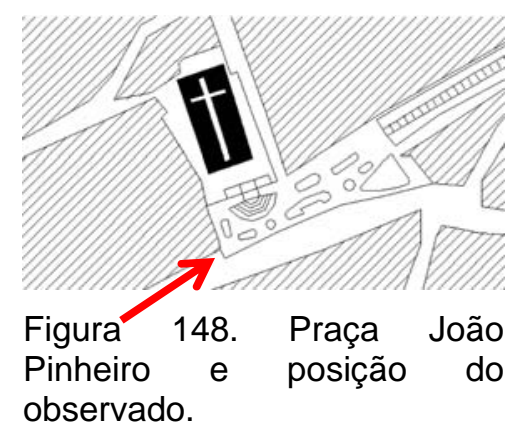

A rua Nagib Bahamed - antiga rua de Cima - quando encontra a praça Dom Epaminondas - antigo largo da igreja da Purificação - passa a se chamar rua Antônio Honório Pires, que termina na praça João Pinheiro. Definimos, então, nossas leituras para chegar a esta praça, partindo da praça Dom Epaminondas. 


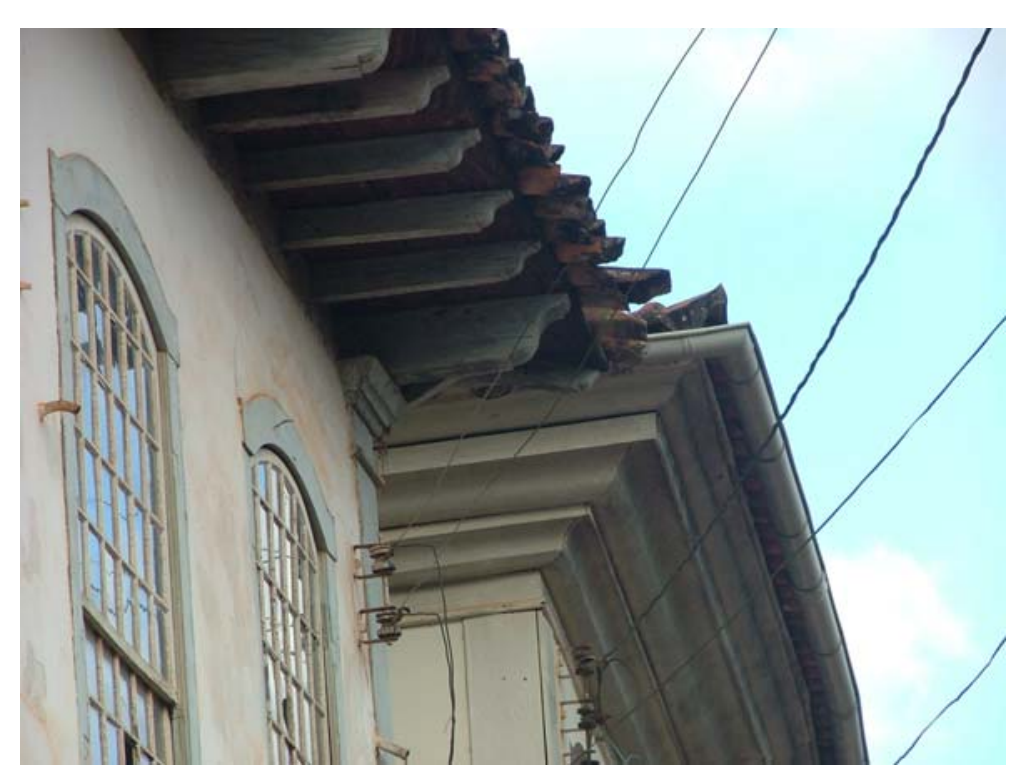

Figura 149. Beirais de sobrados na rua Nagib Bahamed

Se o observador se posicionar no lado esquerdo da via, perceberá um sinuoso caminho delimitado pelos grandes sobrados, marcados por amplos beirais sobrepostos em alguns pontos, e em outros emparelhados devido aos afastamentos laterais entre os edifícios (Figura 149) desta imponente arquitetura, que exibe casarões com telhados com quatro águas em linha contínua, formando os limites do arruamento que conduz ao antigo largo da Cavalhada, ou como era reconhecido na década de 30, "Praça Municipal, ou Jardim Público".
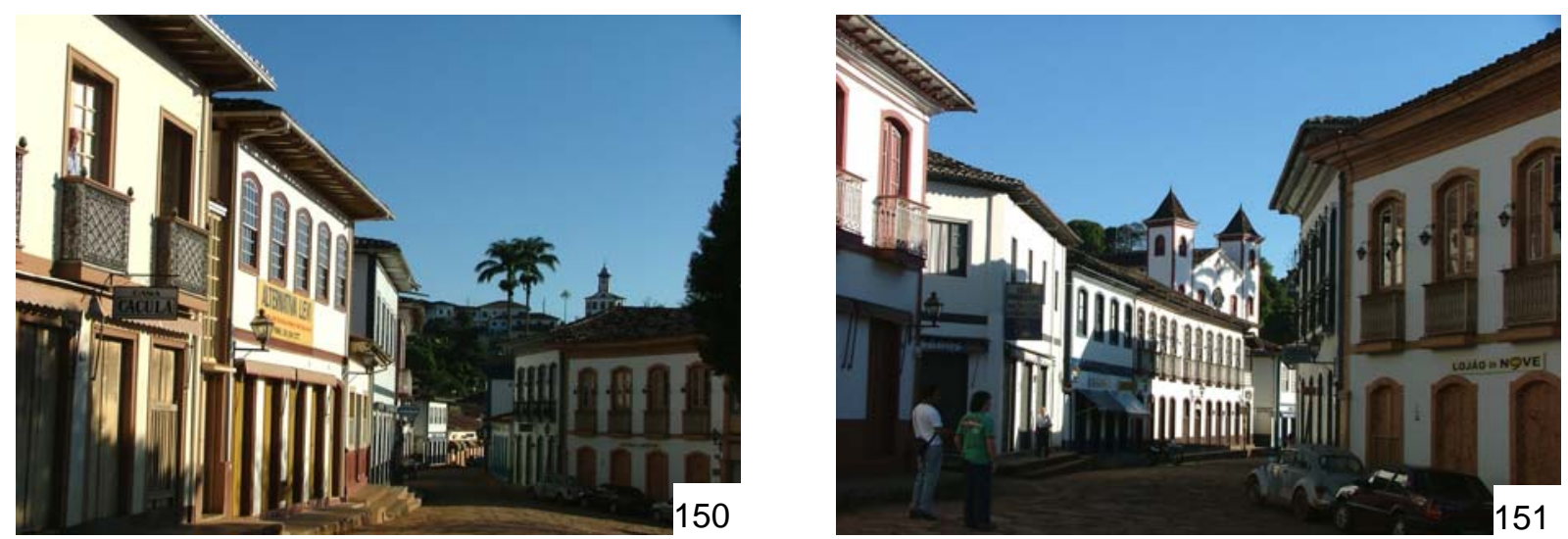

Figura 150. Figura 151. Rua Antônio Honório Pires, em direção à praça João Pinheiro. 

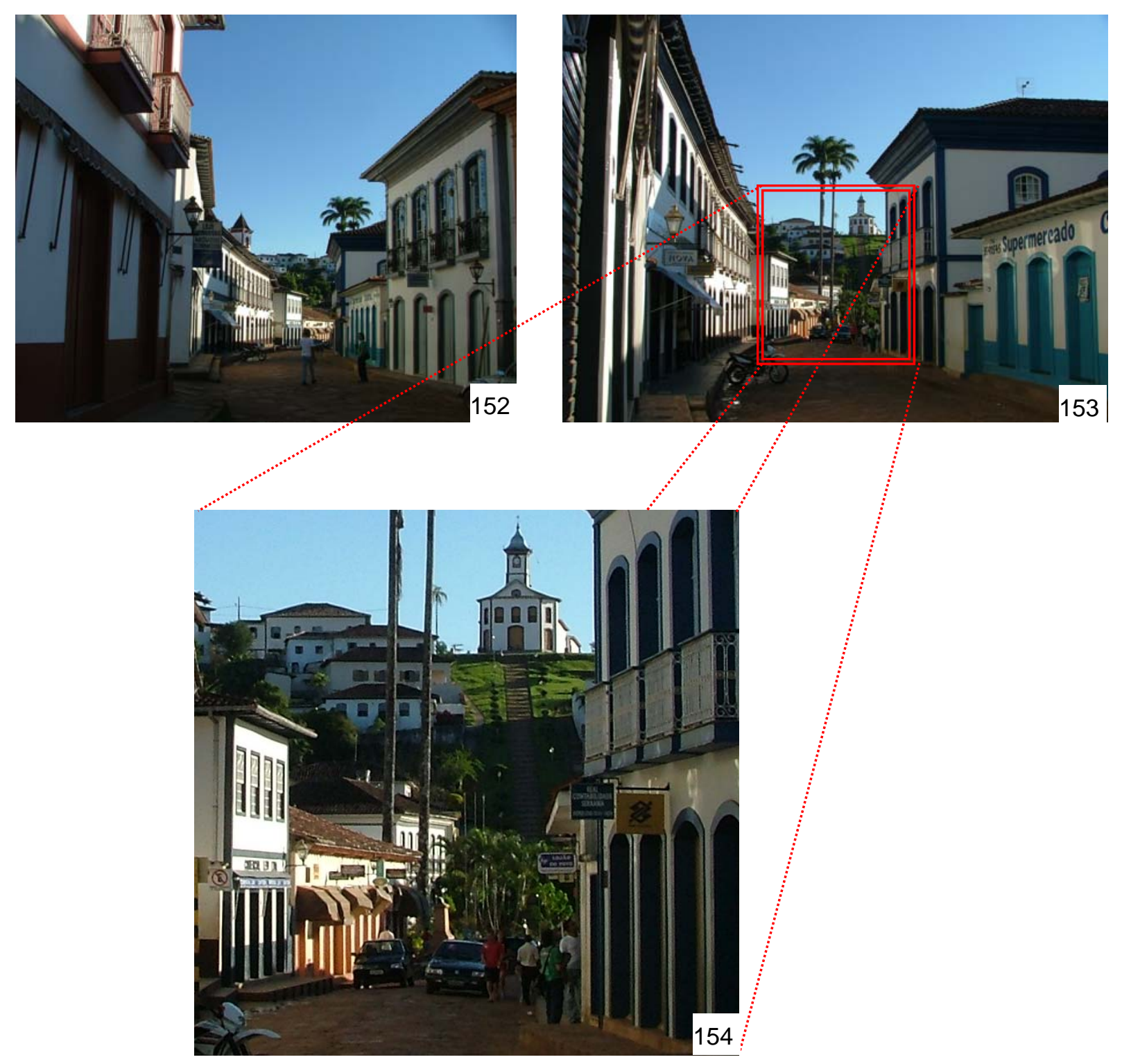

Figura 152. Figura 153. Figura 154. Rua Antônio Honório Pires, em direção à Praça João Pinheiro, Igreja de Santa Rita

A espacialidade deste ambiente nos apresenta a particularidade de termos, do lado esquerdo da rua, como coroamento do casario à direita, a igrejinha de Santa Rita (Figura 150); e ao olhar do observador que se localiza à direta da rua aparece como coroamento do casario do lado esquerdo da via, a igreja de Nossa Senhora do 
Carmo (Figura 151). E, decorrente de uma especial riqueza morfológica, cabe destacar que o acesso a tais igrejas se faz pela praça João Pinheiro, que logo em seguida se mostra marcada fortemente pela escadaria de acesso à igreja de Santa Rita, com implantação em cota de nível a aproximadamente 10 metros acima daquela da praça João Pinheiro (Figura 154).

Entretanto, apesar de perceber que existe uma praça, não a vemos completamente, ainda não temos condições de dominá-la, de saber como ela é. 0 que o posicionamento da praça e da rua nos possibilita é a condução do olhar absolutamente dirigido para a igreja de Santa Rita, destacando a força apelativa do barroco, onde somos colados, na condição de platéia, diante de sua imponência apesar de toda uma simplicidade e singeleza em sua arquitetura. Tanto pela esquerda (Figura 155) como pela direita (Figura 156) ou pelo eixo central do caminho que nos conduz (Figura 157), a igreja de Santa Rita se impõe.
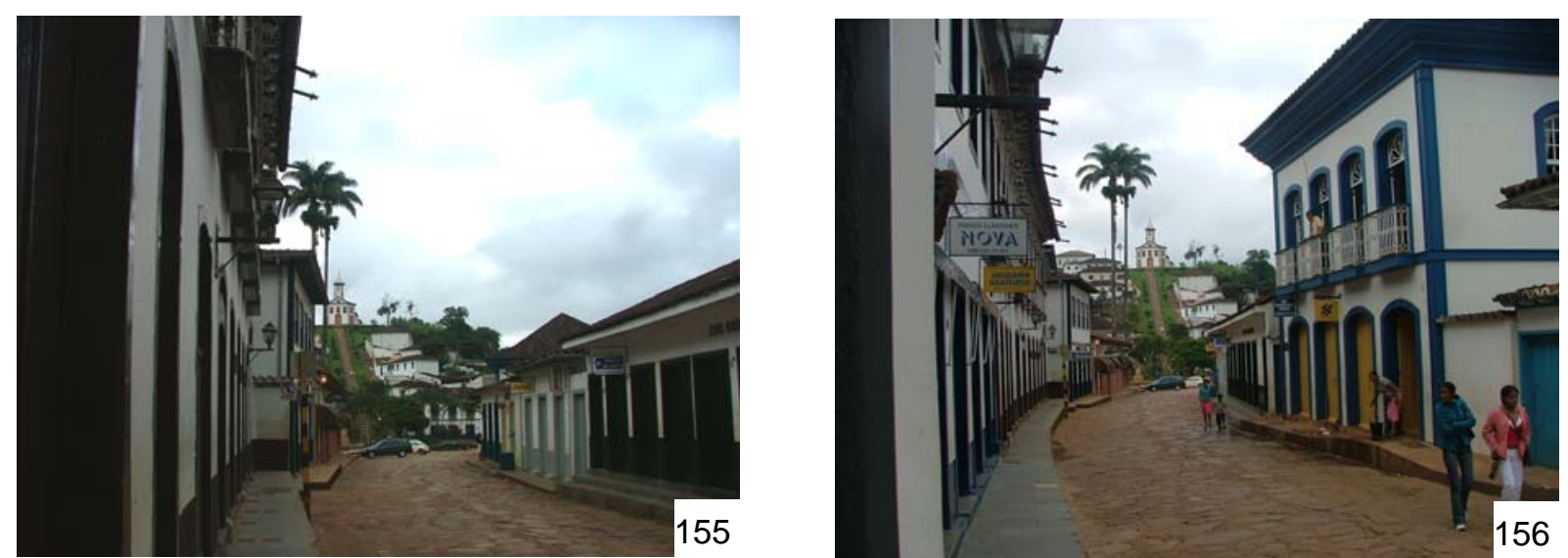

Figura 155, 156. Rua Antônio Honório Pires - sensação de continuidade. A praça não se impõe marcação da força do eixo da igreja Santa Rita 
Figura 157. Rua Antônio Honório Pires - marcação da força do eixo da Igreja Santa Rita

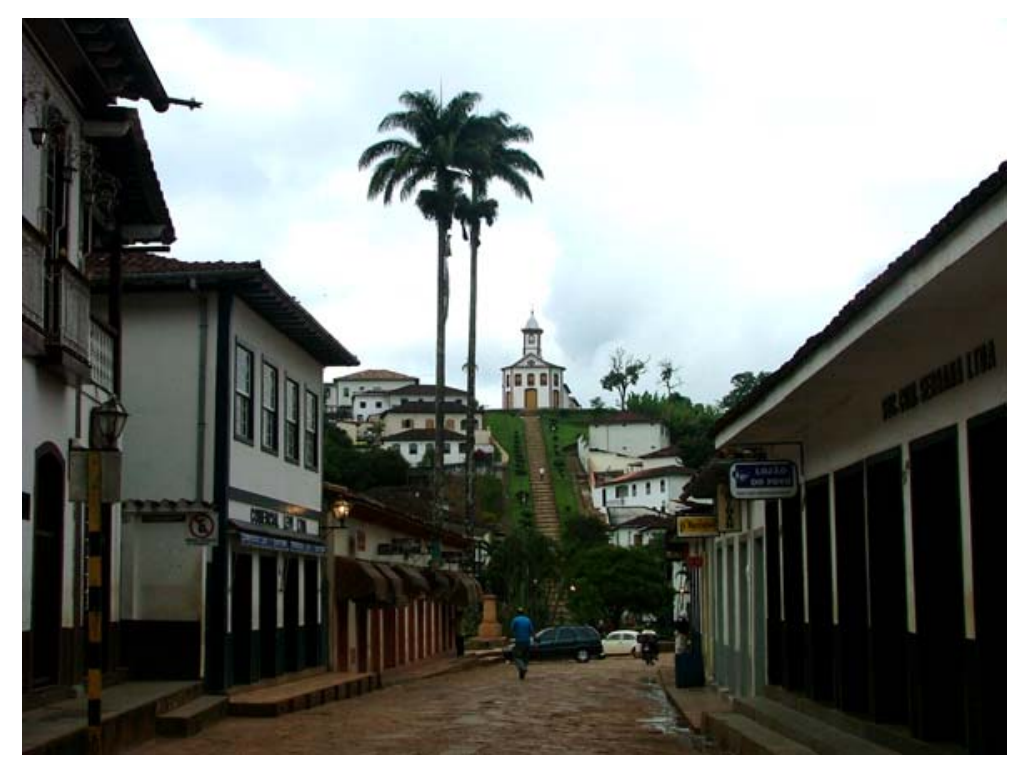

Apenas bem próximo à praça, é que ocorrem ângulos que nos proporcionm outras visões em que a igreja de Santa Rita não é percebida (Figura 158, Figura 159).
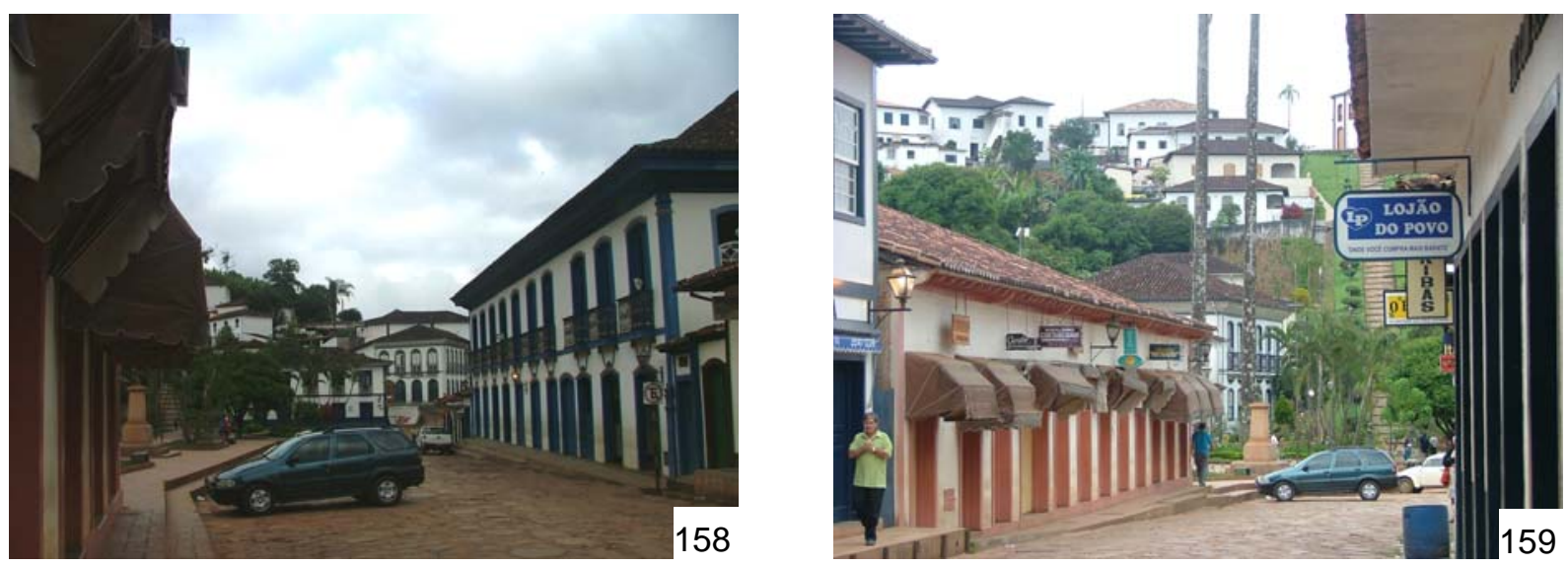

Figura 158. Figura 159. Rua Antônio Honório Pires - encontro com a praça João Pinheiro

Descortina-se, então, a praça de maneira confusa, ela se mostra como "anexo" à rua (da Figura 160 à Figura 165). Ao aproximarmos mais da praça, é que podemos percebê-la de fato, com seus canteiros e bustos de personalidades serranas (da Figura 162 à 165). 

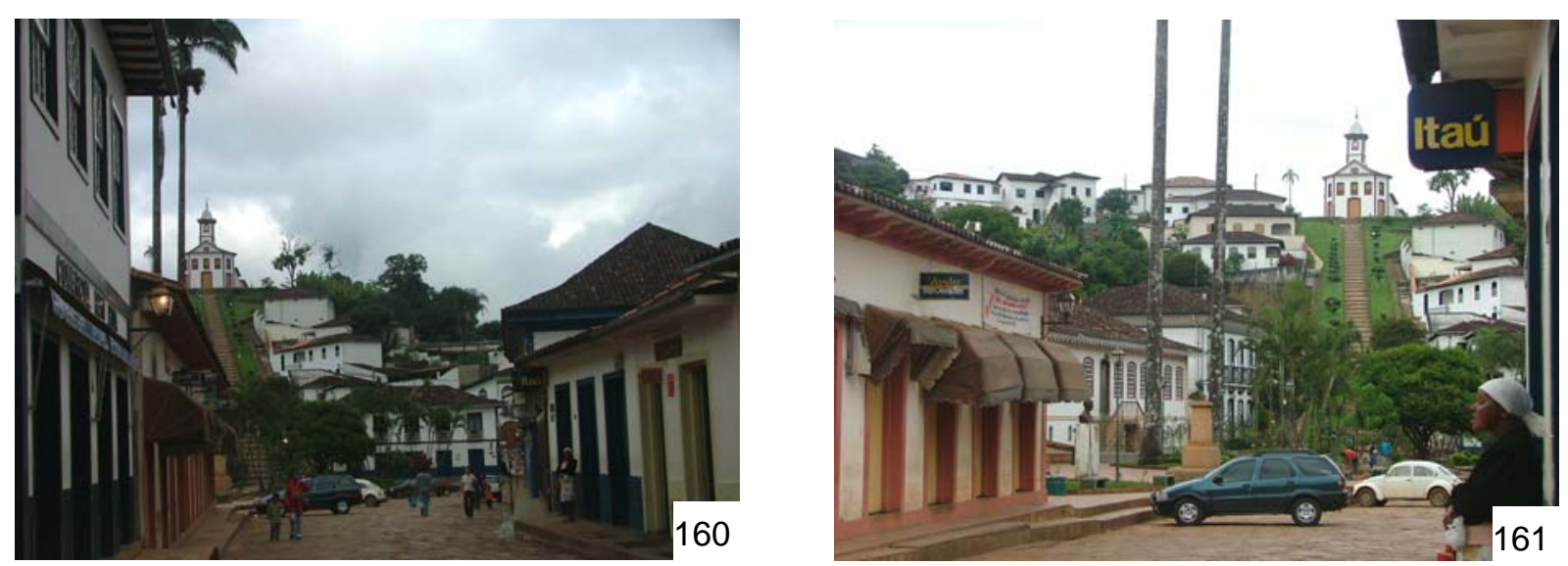

Figura 160. Figura 161. Praça João Pinheiro - chegada pela rua Antônio Honório Pires

Mesmo a praça "parecendo um apêndice da rua", mantém-se coesa, emoldurada, definida, encerrada pelo casario que a envolve. É necessário lembrar das alterações físicas que esta praça sofreu (Figura 166), pois acreditamos que esta imagem confusa com que nos deparamos deve-se à delimitação da rua, com recorte e nivelamento da praça, que originalmente se mostrava como amplo terreiro (Figura 128 e Figura 129) que se abria a partir da rua Antônio Honório Pires, talvez de maneira similar à praça Getúlio Vargas.
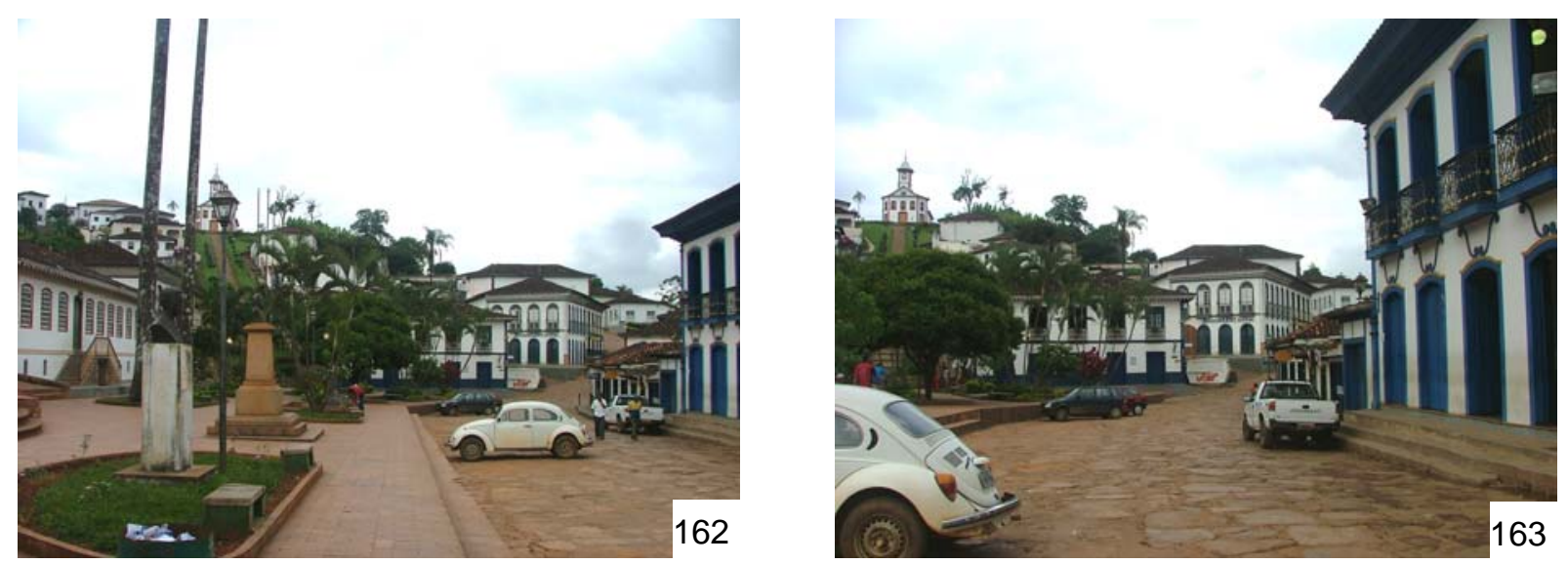

Figura 162. Figura 163. Praça João Pinheiro - encerramento da praça pela rua Fernando Vasconcelos e colina de implantação da igreja Santa Rita 

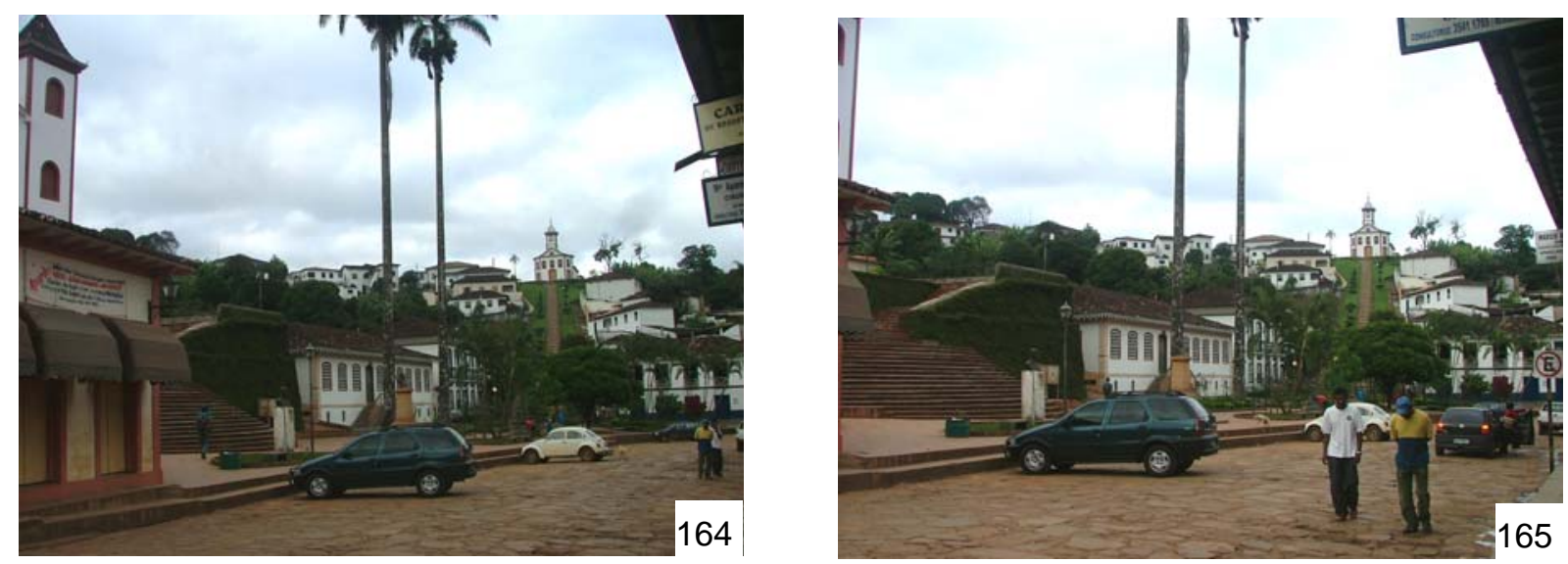

Figura 164. Praça João Pinheiro - eixo da Igreja Santa Rita e surgimento da torre da igreja Nossa Senhora do Carmo. Figura 165. Praça João Pinheiro - eixo da Santa Rita e escadaria de acesso a igreja de Nossa Senhora do Carmo.

O fato é que tudo isso compromete a percepção da praça, mas não destrói sua unidade figurativa. A força de sua coesão e definição espacial prevalece; e, ainda, percebemos seu conjunto formal e estético de expressivo nível qualitativo garantido.

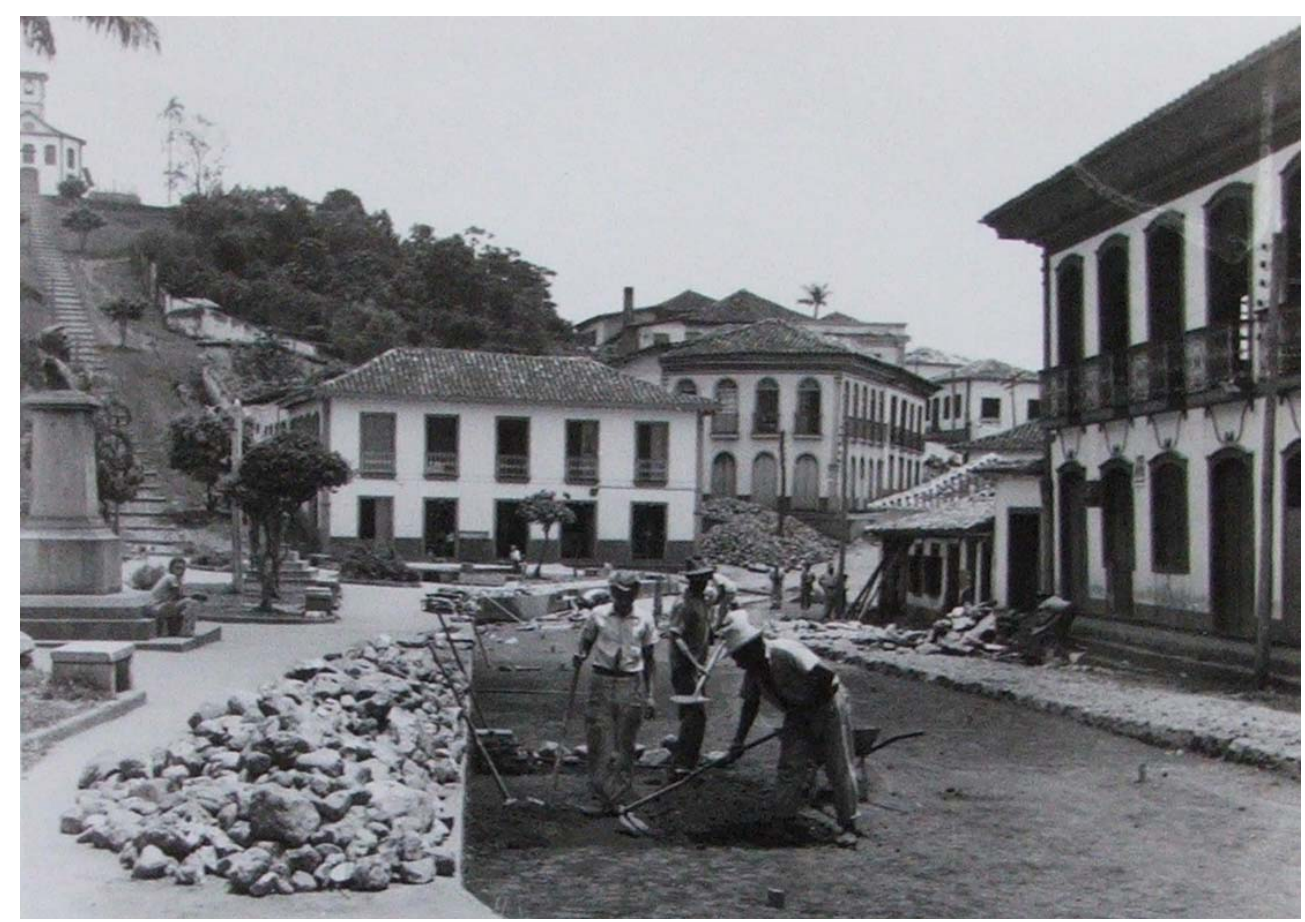

Figura 166. Praça João Pinheiro - obra de pavimentação viária - nivelamento de definição da "caixa" da rua Antônio Honório Pires na praça João Pinheiro. Fonte: IPHAN (2006) 
Ao chegarmos à praça João Pinheiro, no lado esquerdo do acesso, pela rua Antônio Honório Pires, surge a igreja de Nossa Senhora do Carmo que se torna então o elemento definidor e de destaque da praça João Pinheiro, (Figura 169), principalmente para o observador localizado em frente ao monumental edifício da Prefeitura de Serro. A escadaria de acesso ao largo do Carmo, coloca a igreja como que em um palco (Figura 138 à Figura 140), evidenciando sua monumentalidade e destacada escala arquitetônica. Descobrimos, então, que a praça João Pinheiro é platéia para o largo de Santa Rita e Largo do Carmo, estando esta percepção condicionada à posição e olhar do observador (Figura 170).

Tendo como referência parâmetros artísticos definidos por Camillo Sitte (1992), consideraremos, a título ilustrativo nesta pesquisa, o observador em frente ao edifício da igreja Nossa Senhora do Carmo, entendendo que, mesmo se localizado em frente aos demais edifícios de destaque da praça, como a prefeitura e até mesmo a Igreja Santa Rita, as conclusões quanto à artisticidade da praça não seriam marcadas por discrepâncias.

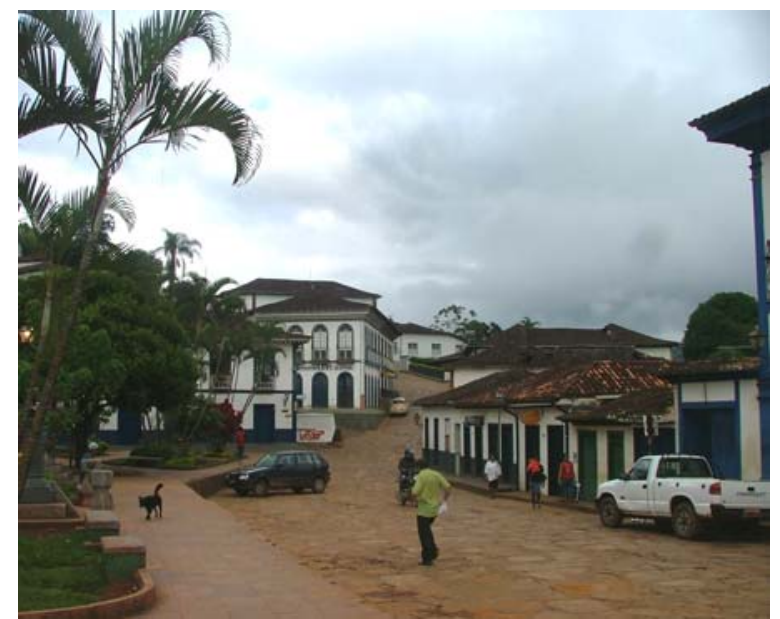

Figura 167. Praça João Pinheiro encerramento pela rua Fernando Vasconcelos.

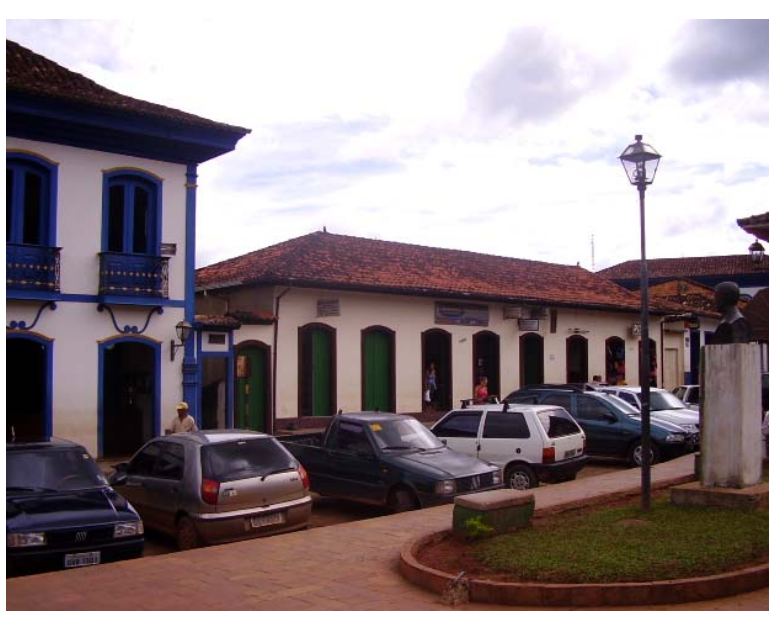

Figura 168. Praça João Pinheiro encerramento pela rua Antônio Honório Pires. 


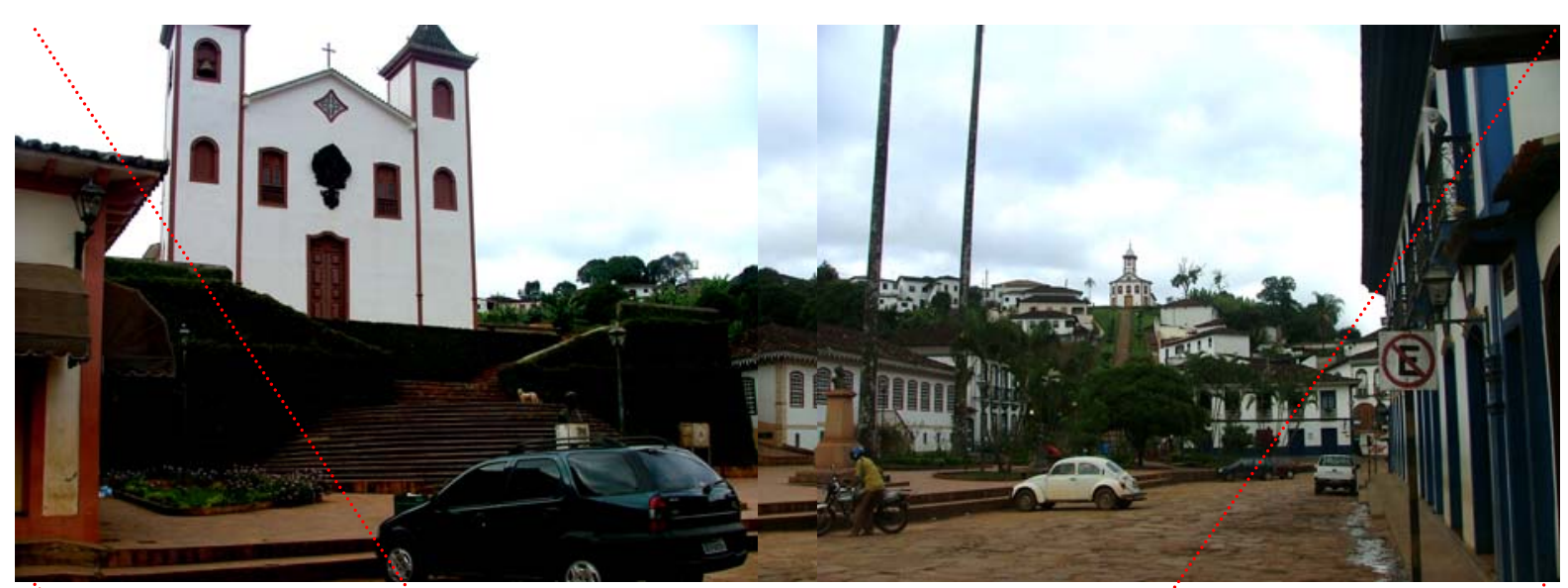

Figura 169. Praça João Pinheiro - relação com as igrejas Nossa Senhora do Carmo e Santa Rita Figura 170. Mapa da praça João Pinheiro e posição do observador.

\section{A percepção da praça João Pinheiro: a partir da rua Fernando Vasconcelos}

A declividade da rua Fernando Vasconcellos é expressiva, ocorre uma grande diferença de nível ao longo dela e a praça João Pinheiro. No extremo da rua, quando 
ela encontra a praça Pedro Lessa, estamos praticamente na mesma cota de nível de implantação da igreja Santa Rita, evidenciando um traçado viário transversal às curvas de nível (Figura 171 e Figura 173).
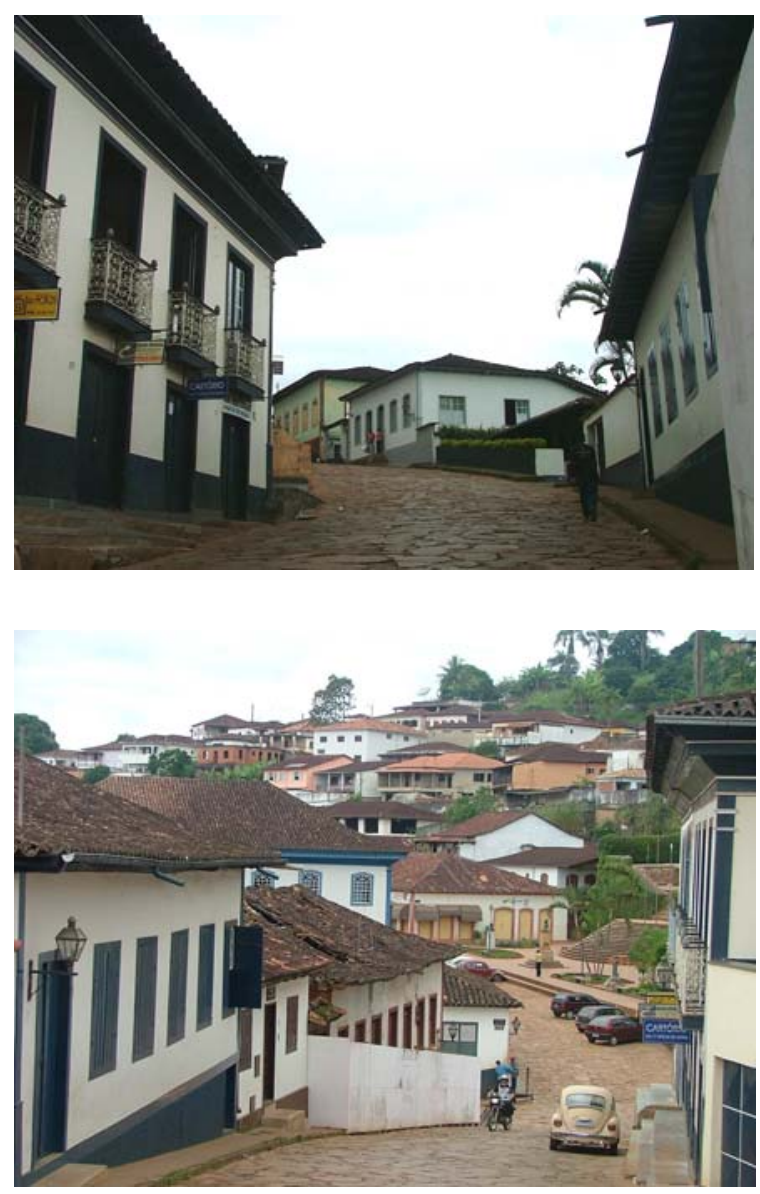

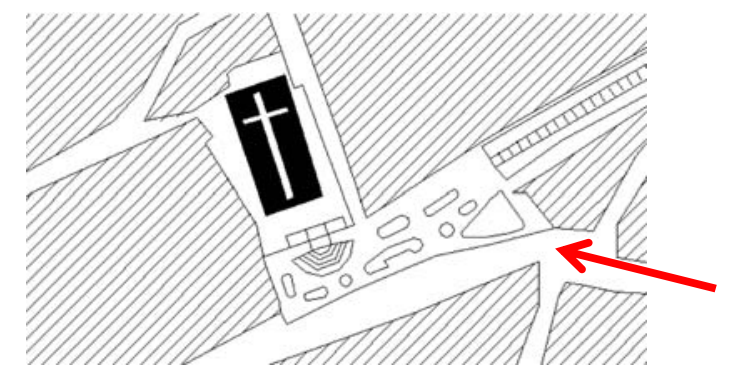

Figura 171. Rua Fernando Vasconcelos (observador de costas para a praça João Pinheiro)

Figura 172. Mapa da praça João Pinheiro e posição do observador na rua Fernando Vasconcellos

\begin{abstract}
Figura 173. Rua Fernando Vasconcelos - surgimento da praça João Pinheiro - escadaria da igreja do Carmo - destaque para a marcação do eixo viário diante da praça
\end{abstract}

Como a grande maioria dos caminhos da cidade, esta rua é sinuosa, mas não se mantém em uma mesma cota de nível; neste sentido, se comporta como as travessas - rompendo perpendicularmente a diferença de nível para passar de uma rua a outra. Quando o observador, descendo a rua Fernando Vasconcellos, se posiciona no ponto extremo da curva que encerra a rua, conforme (Figura 173), é 
percebida pela primeira vez a presença da praça João Pinheiro, que, apesar da delimitação da rua que a recorta, é nítido o seu alargamento mantendo-se o entendimento de que foi, no passado, um amplo terreiro (Figura 176 à Figura 178). Acreditamos que, conforme Brandi (2005), a unidade potencial da obra de arte está garantida, apesar das alterações físicas e morfológicas que aconteceram.

À medida que caminhamos, descendo a rua Fernando Vasconcellos em ziguezague, ora à direita e ora à esquerda da via, ampliamos a percepção da praça. Surgem os degraus de acesso para o largo do Carmo, na seqüência as torres da igreja, que vai se mostrando gradativamente (Figura 174, Figura 175) até que percebamos sua imponência absolutamente dominante na paisagem da praça, para o observador localizado à esquerda da rua Fernando Vasconcellos (Figura 176, Figura 178).
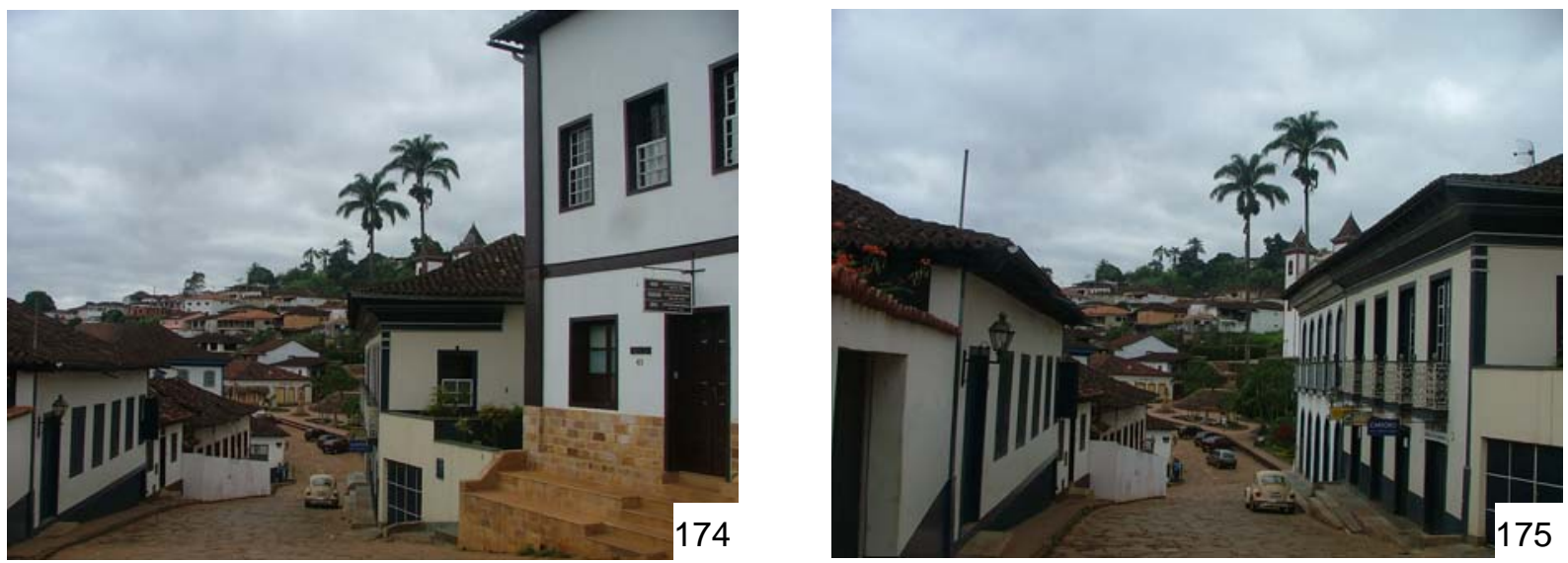

Figura 174. Figura 175. Praça João Pinheiro - surgimento a partir da rua Fernando Vasconcellos

Mas a igreja torna-se inexistente para aquele que se posiciona à direita da rua Fernando Vasconcellos, que não vê a praça como elemento principal, mas a rua que 
se finda em sua própria silhueta -e passará a chamar Antônio Honório Pires (Figura 177).
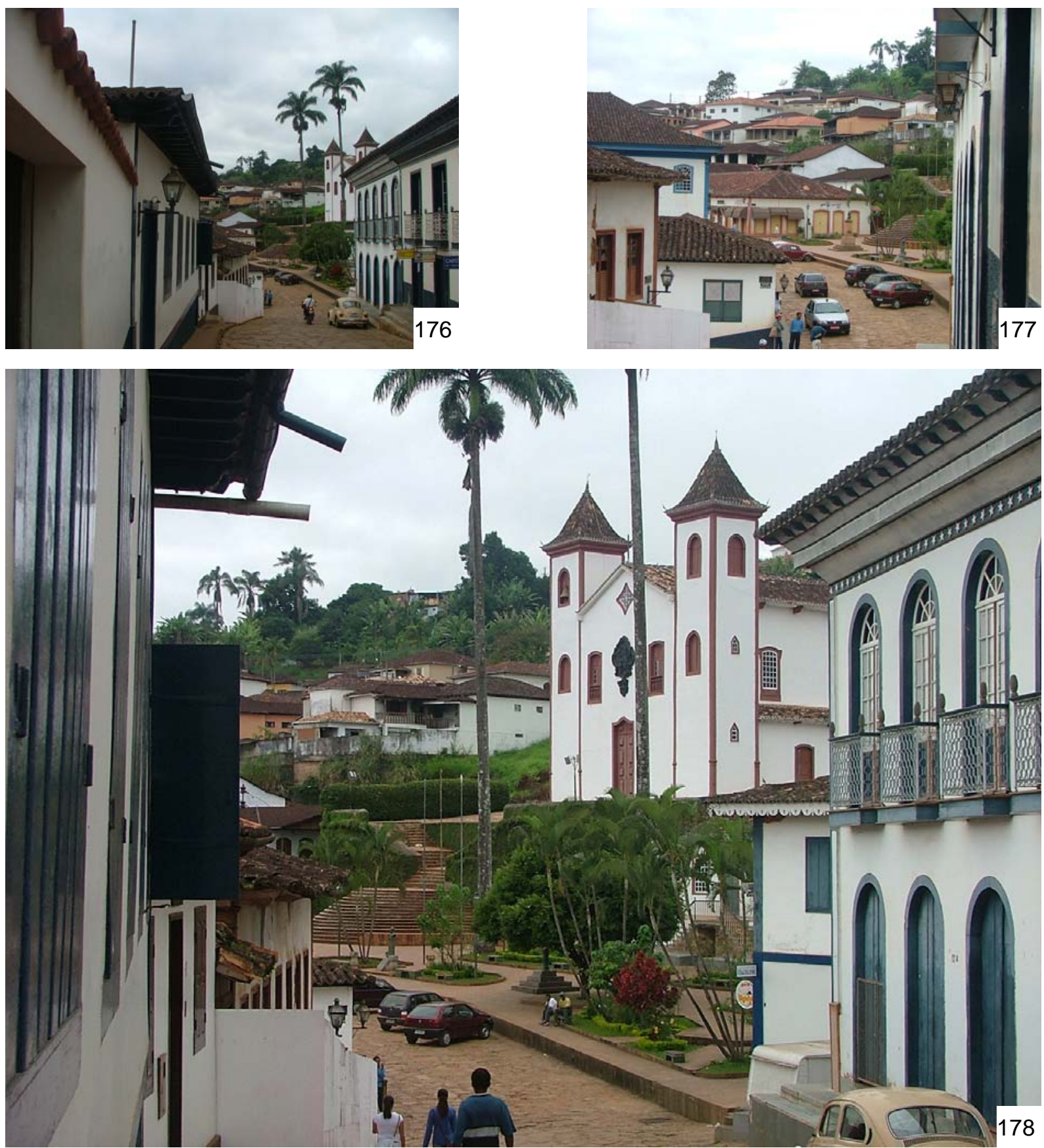

Figura 176. Figura 177. Figura 178. Percepção da praça João Pinheiro a partir da rua Fernando Vasconcelos // Igreja Nossa Senhora do Carmo 
Chegando à praça João Pinheiro por este percurso, a travessa Magalhães não é notada (Figura 179), pois trata-se de caminho praticamente perpendicular à praça, sendo possível sua percepção apenas quando já nos encontramos defronte a ela (Figura 180), talvez com a posição de "pá" (Figura 183) - conforme entendimento de Camillo Sitte (1992) -, participando de uma adequada posição para a percepção de fechamento da praça João Pinheiro.
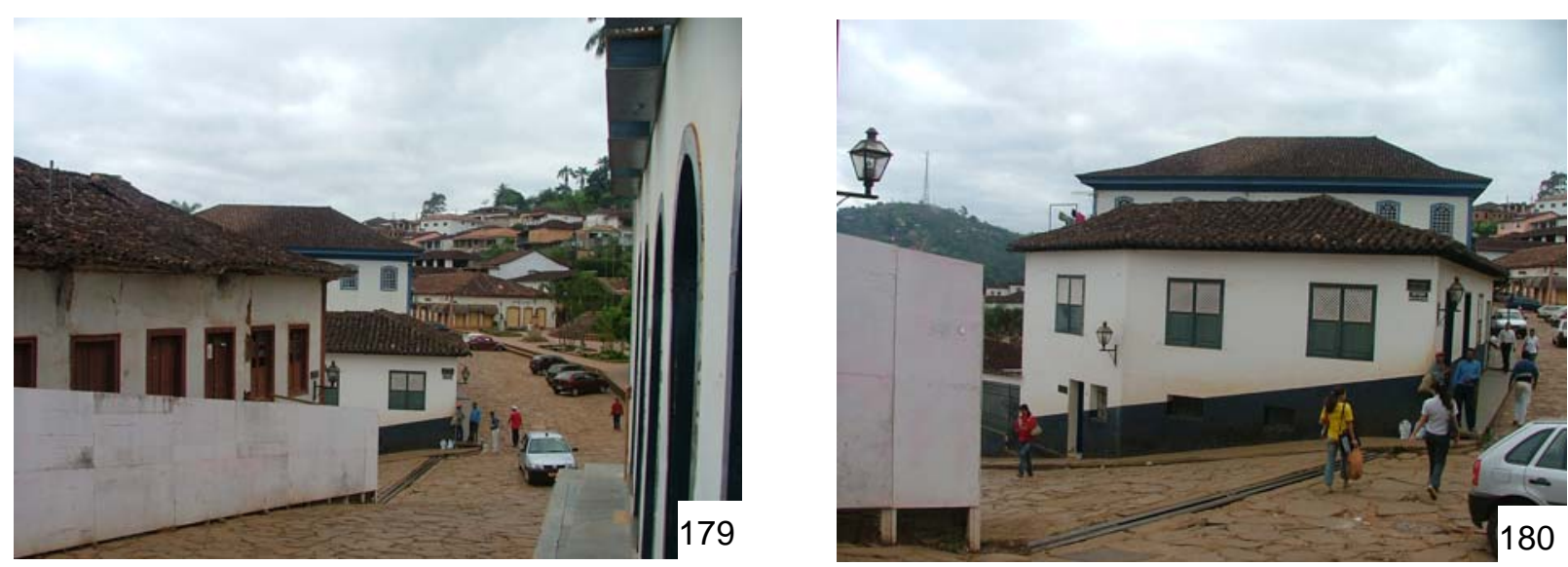

Figura 179. Figura 180. Praça João Pinheiro - relação com a travessa Magalhães.

\section{A percepção da praça João Pinheiro: a partir da travessa Magalhães}

A travessa Magalhães, talvez pela sua condição de via secundária de ligação entre caminhos mais importantes na formação da cidade, não cria fortes 
expectativas quanto àquela com que nos depararemos ao seu findar. Ao contrário, em seu início, vislumbramos um aclive em linha reta se encerrando no casario (Figura 181 e Figura 182) que continua por um estreito beco (Figura 185).

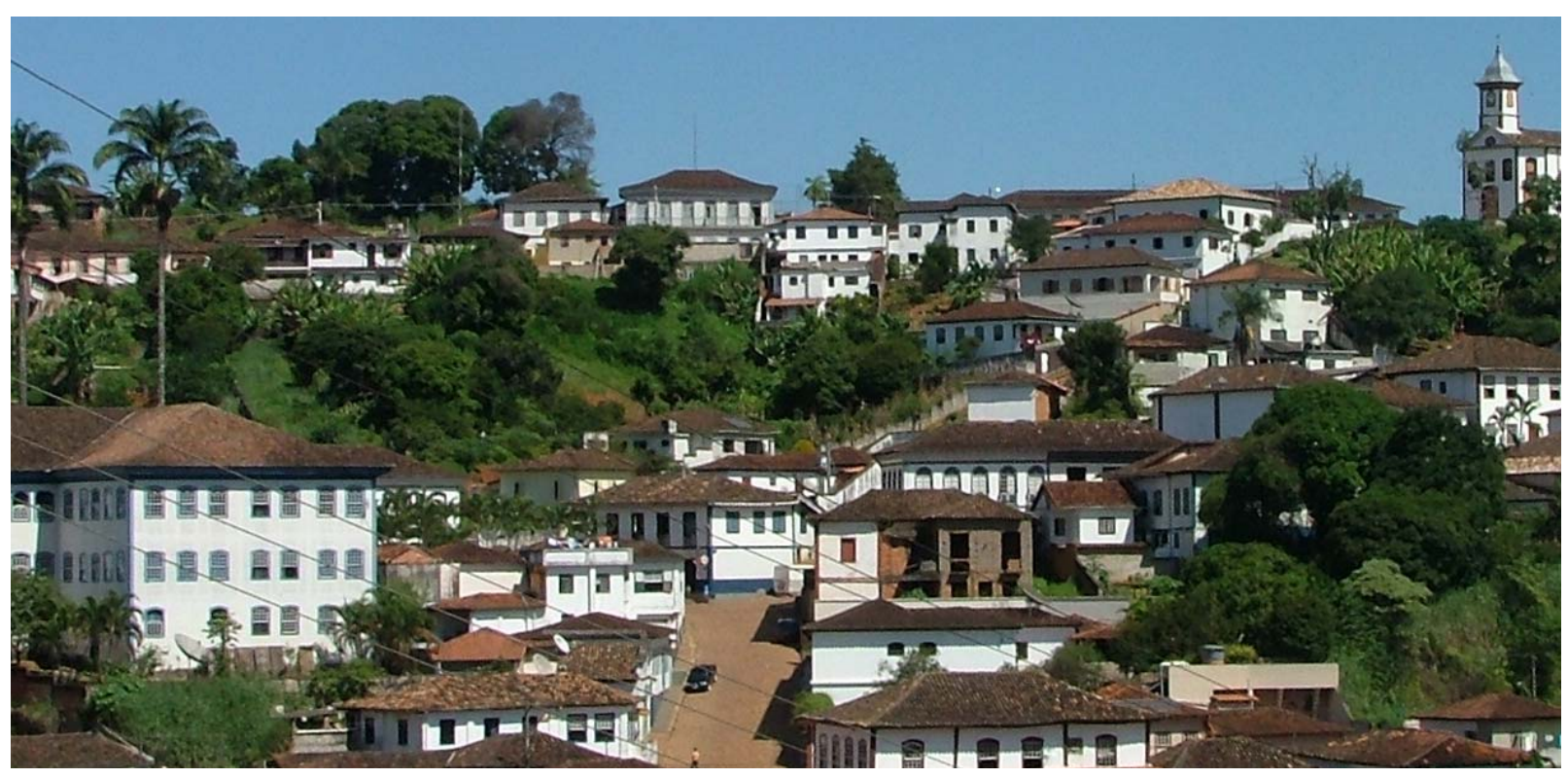

Figura 181. Travessa Magalhães - vista panorâmica.

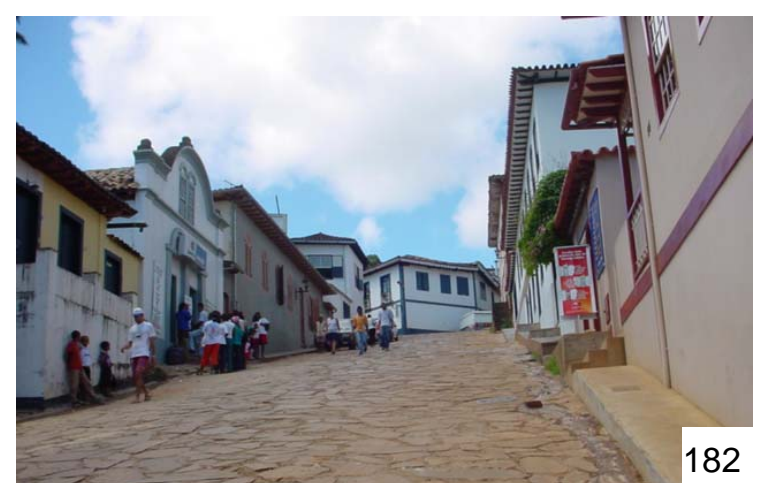

Contudo, ao término do percurso, nos deparamos à direita com a rua Fernando Vasconcellos (Figura 187), e à esquerda com a praça João Pinheiro (Figura 186) e com a magnitude da igreja Nossa senhora do Carmo (Figura 188).

Destaca-se uma grande revelação, inesperada, gerada pela surpresa proporcionada 
pela geografia e posicionamento da travessa em relação à praça, demonstrando planejamento e intenção quanto à valorização e criação artística do ambiente urbano envolvido pelos elementos indicados (via, praça, casario, geografia, dentre outros).
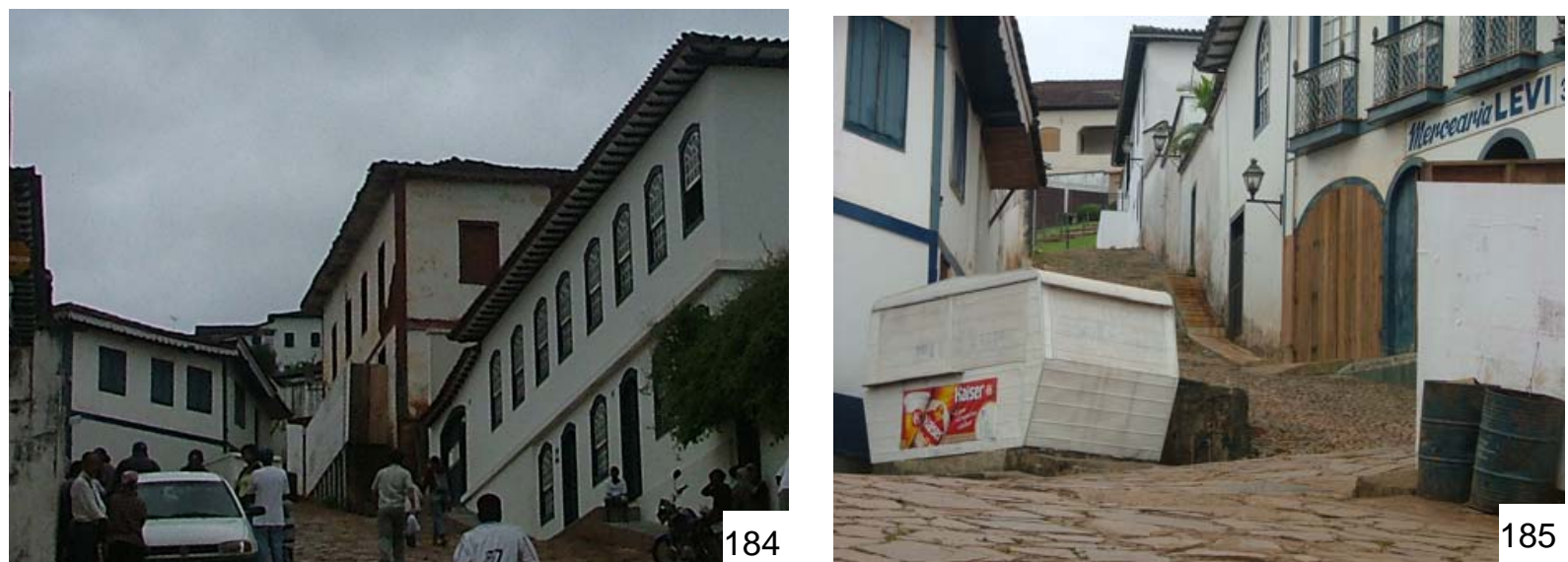

Figura 184. Figura 185. Acesso à praça João Pinheiro pela travessa Magalhães

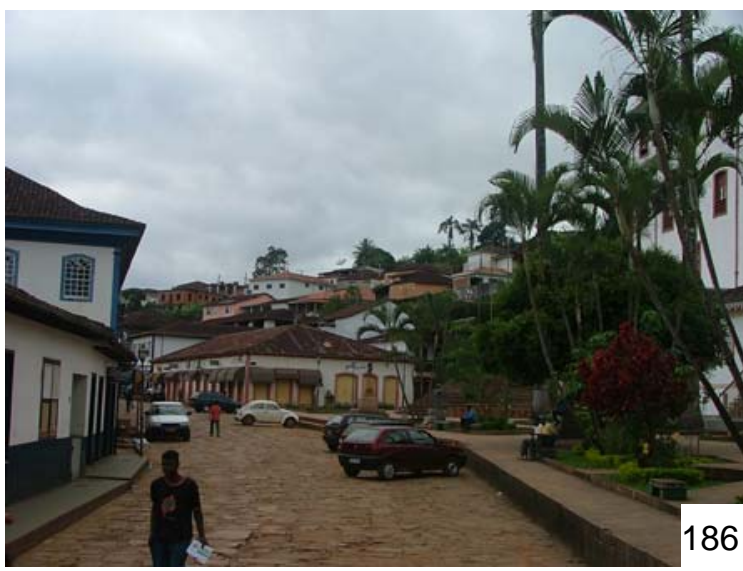

Figura 186. Praça João Pinheiro - acesso pela travessa Magalhães - esquerda do observador

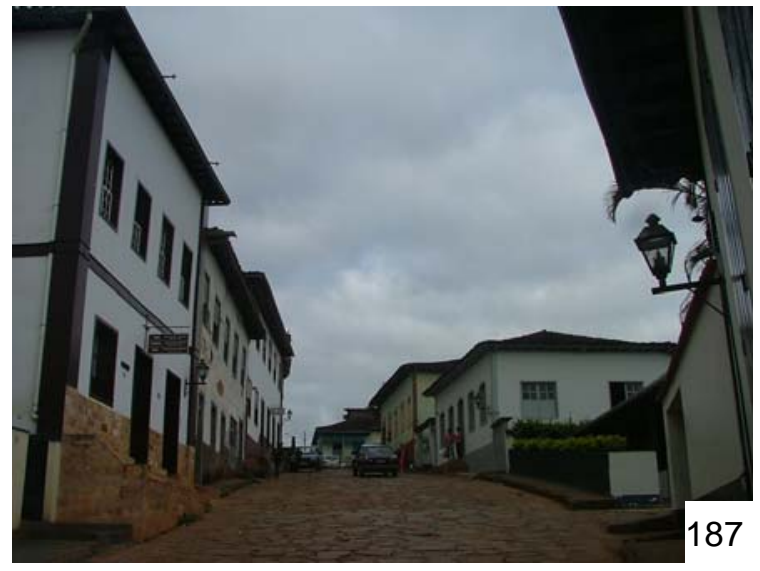

Figura 187. Praça João Pinheiro - acesso pela travessa Magalhães - direita do observador

Entendemos que a praça João Pinheiro representa importante atribuição na estruturação do espaço urbano de Serro. Acreditamos que isso se deve muito à consolidação da cidade no final do século XVIII e início do XIX (Figura 127). 


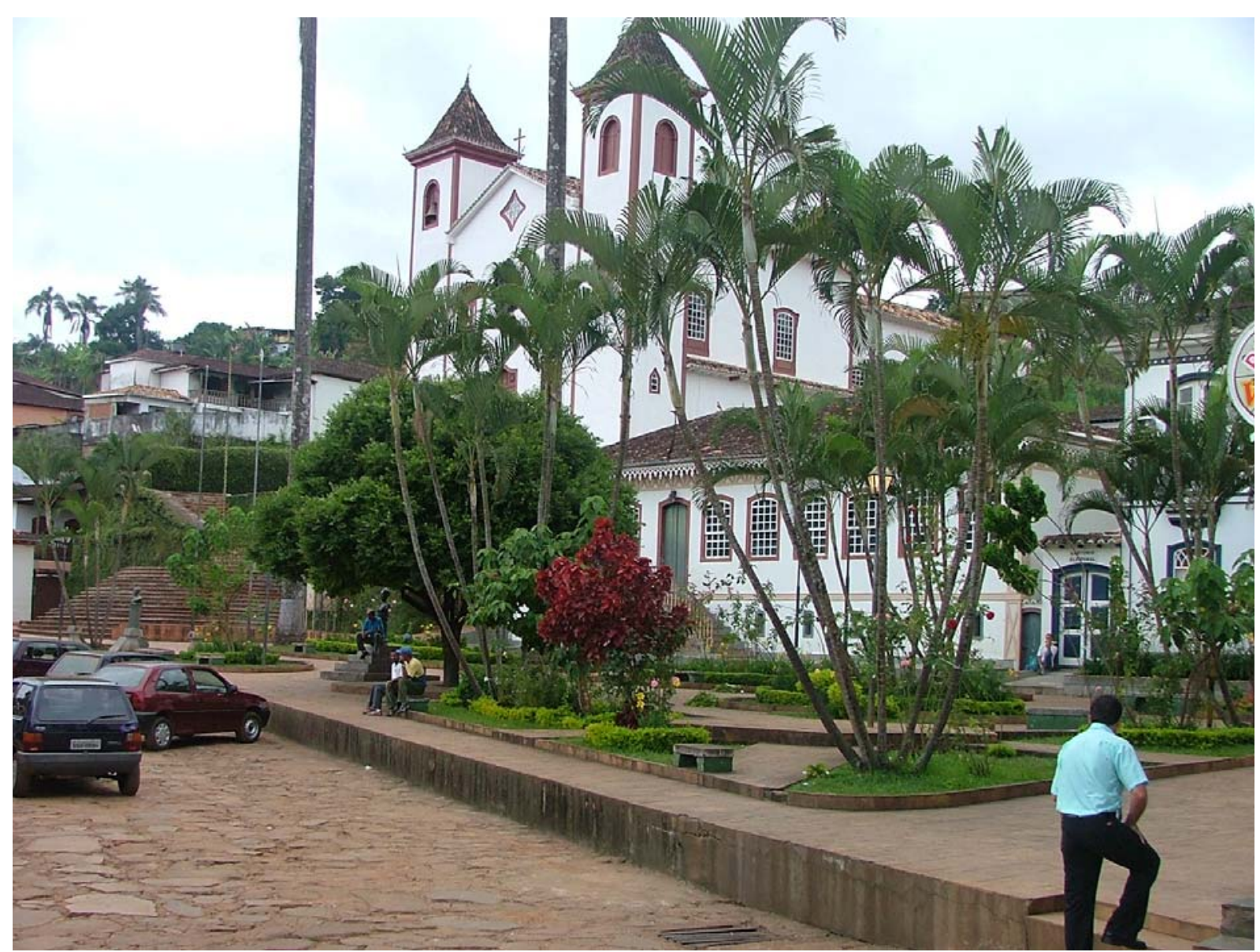

Figura 188. Praça João Pinheiro - encerramento pela rua Fernando Vasconcelos - vista pela esquerda do observador

Como sabemos, a igreja de Nossa Senhora do Carmo é de construção posterior à de Santa Rita, e que no século XVIII a praça João Pinheiro estava em um dos extremos da Vila, funcionando como local inclusive de treinamentos militares. É marcada por características espaciais dos séculos XVIII e XIX. Entretanto, no século $X X$, foi centro de interesse de austeras transformações morfológicas, resultando em fortes conflitos quanto à evidência de sua figuratividade enquanto espaço autêntico. 

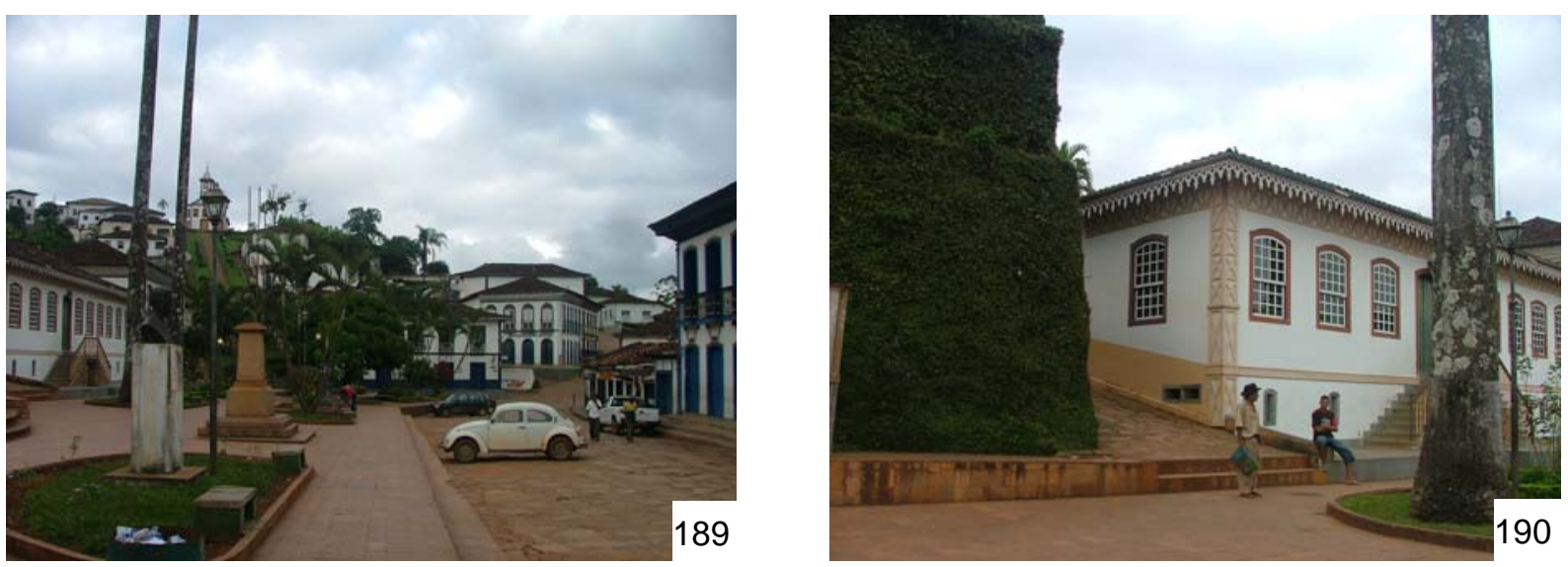

Figura 189. Praça João Pinheiro pavimentação, canteiros, vegetação, diferença de níveis

Figura 190. Praça João Pinheiro - obstrução do beco do Carmo.

Figura 191. Vista do Beco do Carmo a partir da praça João Pinheiro

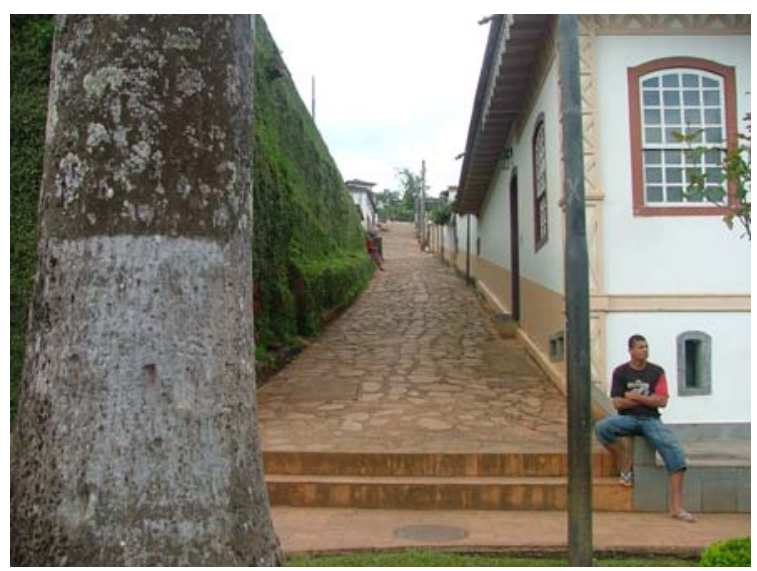

Figura 192. Conexão do Beco do Carmo com a antiga rua do Corte - pela lateral da Igreja do Carmo

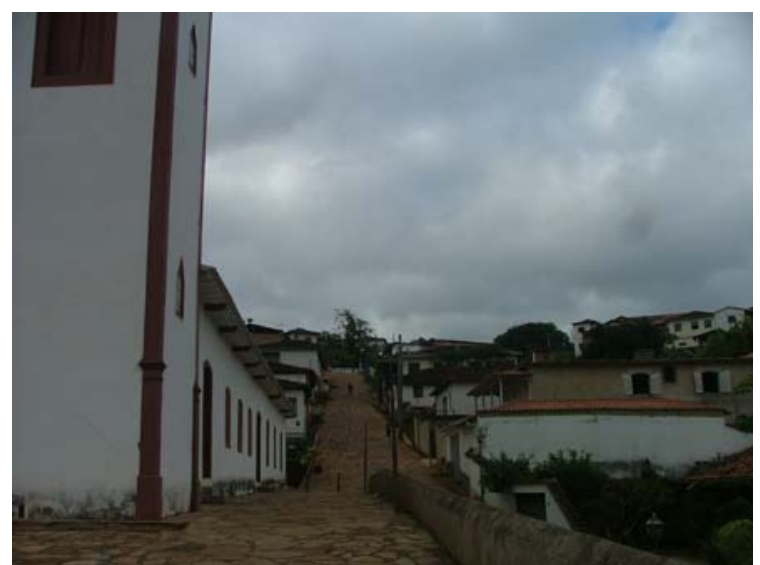

Podemos indicar, desde a interrupção de via, até alteração de pavimentação, definição de diferença de níveis topográficos, vegetação, substituição de edificações 
antigas por novas "reconstruções", o que poderia colocar em dúvida a integridade do conjunto urbano enquanto obra de arte.

Entretanto, essas alterações foram "em uma parte" da cidade "monumento", e não são entendidas isoladamente, pois a cidade é representada por "um inteiro". O que podemos perceber é que a praça é fechada, coesa, e mantém sua unidade e artisticidade; Tendo como referência Camillo Sitte (1992), podemos indicar alguns parâmetros a serem considerados:

- Ela se aproxima daquela do tipo larga - o conflito ocorre devido à força monumental da igreja de Nossa Senhora do Carmo ser maior que a do prédio da prefeitura (normalmente este tipo de configuração ocorre para edifícios administrativos/ civis). E o domínio da igreja do Carmo é, em alguns pontos, relativizado pelo da Igreja de Santa Rita, que poderia tornar a praça do tipo comprida; entretanto, ela é dominada pela fachada da igreja do Carmo (Figura 167).

- Nela é possível perceber uma edificação de importância destacada -sua forma/ dimensão/ ornamentação figurativa - (Figura 167 e Figura 188).

- Pode ser entendida como fechada, se considerarmos seu emolduramento pela arquitetura, e ângulo de ligação entre ruas e caminhos conectados a ela (Figura 167 e 170 e Figura 188 e 189).

- É formada por amplos espaços livres em potencial (perdas por colocação de bustos e vegetação em seu interior). 
- Nela a igreja do Carmo é o componente básico (apesar da importância da edificação da Prefeitura e o forte eixo da igreja de Santa Rita, que é minimizado no conjunto devido à pequena escala volumétrica de sua arquitetura).

- Nela a construção da igreja está afastada do plano da praça a partir de muro de arrimo que a coloca em palco acima do nível da praça, sem interromper o fechamento do conjunto.

- Nela a construção da igreja não é geminada a outras edificações.

Destacamos transformações espaciais percebidas nesta praça, tais como: a interrupção do beco do Carmo (Figura 190 e Figura 191); definição de níveis altimétricos do piso da praça (Figura 188, Figura 189); acréscimo de novos degraus para acesso ao adro da igreja de Nossa Senhora do Carmo; marcação da "caixa" da rua em frente à praça João Pinheiro (Figura 189); adensamento do ambiente que envolve a praça - construção de novas edificações onde havia áreas verdes /livres (Figura 177, Figura 178); construção de jardim com vários espécimes de plantas na praça (Figura 186, Figura 188). 


\section{PRACCA DOM EPAMINONDAS}

Entendemos que a praça Dom Epaminondas não existe de fato. O que é assim denominado é o espaço remanescente do que fora o largo da Purificação, direcionado para a antiga praça da Cavalhada; atualmente se mostra como uma imensa lacuna da igreja da Purificação, que originalmente estava construída no alinhamento do casario, integrada a ele, entalada na arquitetura (como ocorre com a Igreja de Nossa Senhora do Amparo em Diamantina), definindo e delimitando o arruamento de uma das principais vias de formação de Serro (Figura 204).

Como é uma lacuna, a praça Dom Epaminondas revela descontinuidade do tecido figurativo urbano de Serro. E, por ser resultante da ausência de um monumento de grande escala e estar em posição de destaque no conjunto urbano, a percepção desta realidade parece se tornar evidente (Figura 212).

Consideramos a antiga rua de Cima de destacada importância na formação de Serro - atual rua Nagib Bahamed - e por percorrer a fachada posterior da Igreja Matriz de Nossa Senhora da Conceição, optamos por partir deste ponto com destino à "praça Dom Epaminondas", onde chegaríamos à igreja da Purificação pela lateral esquerda. Posteriormente desvendaremos os acessos à praça Dom Epaminondas, buscando o que seria a fachada principal da igreja Purificação, que representa a confluência da rua Antônio Honório Pires com a Nagib Bahamed (visualmente representa uma única via - (Figura 193)). 


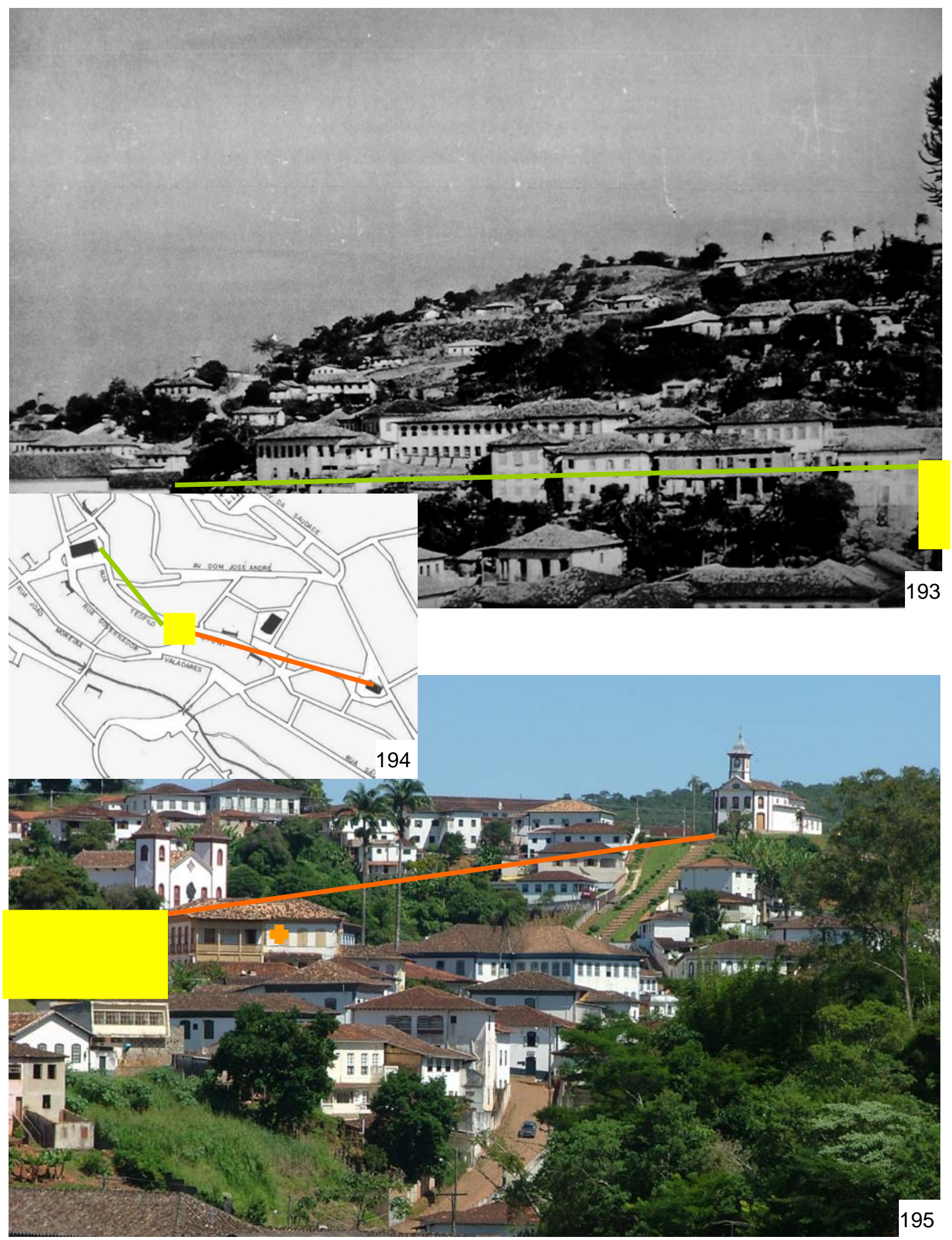

Figura 193. Figura 194. Figura 195. Localização da antiga Igreja da Purificação, atual praça Dom Epaminondas, em relação à Igreja Nossa Senhora da Conceição (Matriz) e Igreja Santa Rita. Fonte: IPHAN (2006) 
O ponto da praça Dom Epaminondas, mesmo sem a igreja da Purificação carrega o tributo de conector entre a igreja Nossa Senhora da Conceição, igreja Nossa Senhora do Carmo e igreja Santa Rita com suas respectivas praças, ou largos, que podem ser interpretados como vinculados a um único caminho, apesar da diversidade e riqueza de relações que esses monumentos religiosos possibilitam, ou trazem à paisagem urbana (Figura 193 a Figura 195).

Devido à ausência da igreja da Purificação, atual praça Dom Epaminondas, será identificada em figuras com o auxílio de marcadores que utilizaremos nas edificações que se tornaram de referência nas imagens selecionadas ao longo dos percursos estabelecidos. Os marcadores têm forma de uma cruz, e se tornam uma referência para a edificação que se repete em cada imagem, servindo como auxílio ao leitor.

\section{A percepcão da praça Dom Epaminondas: a partir da rua Nagib Bahamed}

A rua Nagib Bahamed, antiga rua de Cima, é uma das vias mais antigas do Serro, caminho de destaque na formação da cidade, liga a igreja Matriz à antiga praça da Cavalhada praticamente por uma única cota de nível. Tendo em vista a ocupação de Serro em encosta de elevada declividade, a sinuosidade da rua Nagib Bahamed realça o movimento transmitido à arquitetura que, a cada trecho de 
deslocamento do observador, propicia um novo horizonte, uma realidade urbana desconhecida (Figura 193 à Figura 203).
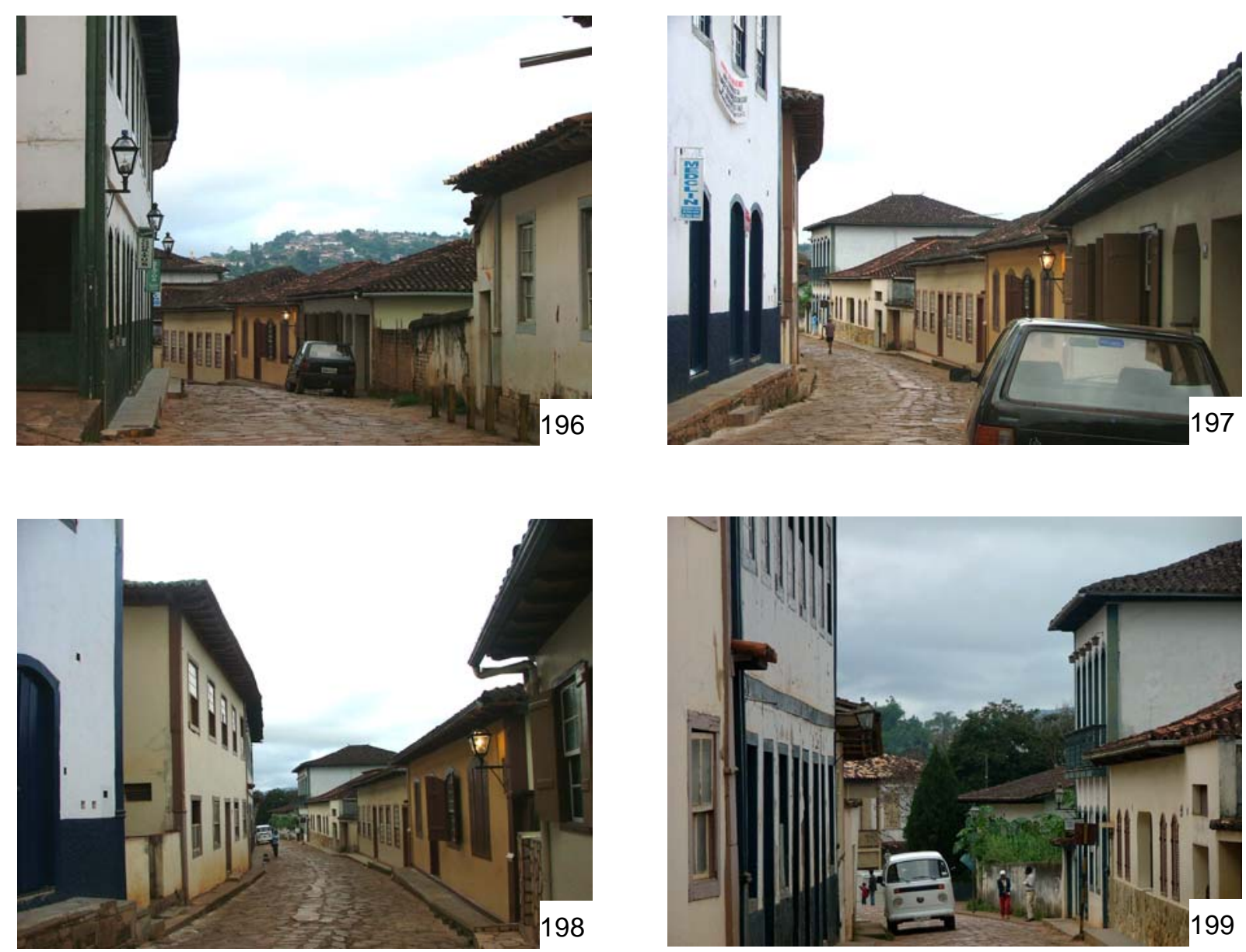

Figura 196. Figura 197. Figura 198. Figura 199. Rua Nagib Bahamed sentido praça Dom Epaminondas.

À medida que caminhamos, percebemos que todo o movimento desenvolvido pela rua nos conduz à praça João Pinheiro, que é insinuada, num primeiro momento, pela igreja Santa Rita (Figura 203). Este direcionamento é desvirtuado pela praça Dom Epaminondas, que se mostra como uma ausência de continuidade arquitetônica (Figura 202) - ocorre a "falta do amparo" que sustenta o transeunte no sentido de um destino que não é a praça Dom Epaminondas - é como se 
estivéssemos descendo uma escada, segurando em um corrimão e, de repente, lhe faltasse um pedaço e ficássemos por alguns instantes desamparados. Entendemos que a cidade, com a ausência da igreja da Purificação, "chama por socorro", através desta lacuna denominada praça Dom Epaminondas (Figura 199, 200 e da figura 205 à 207).
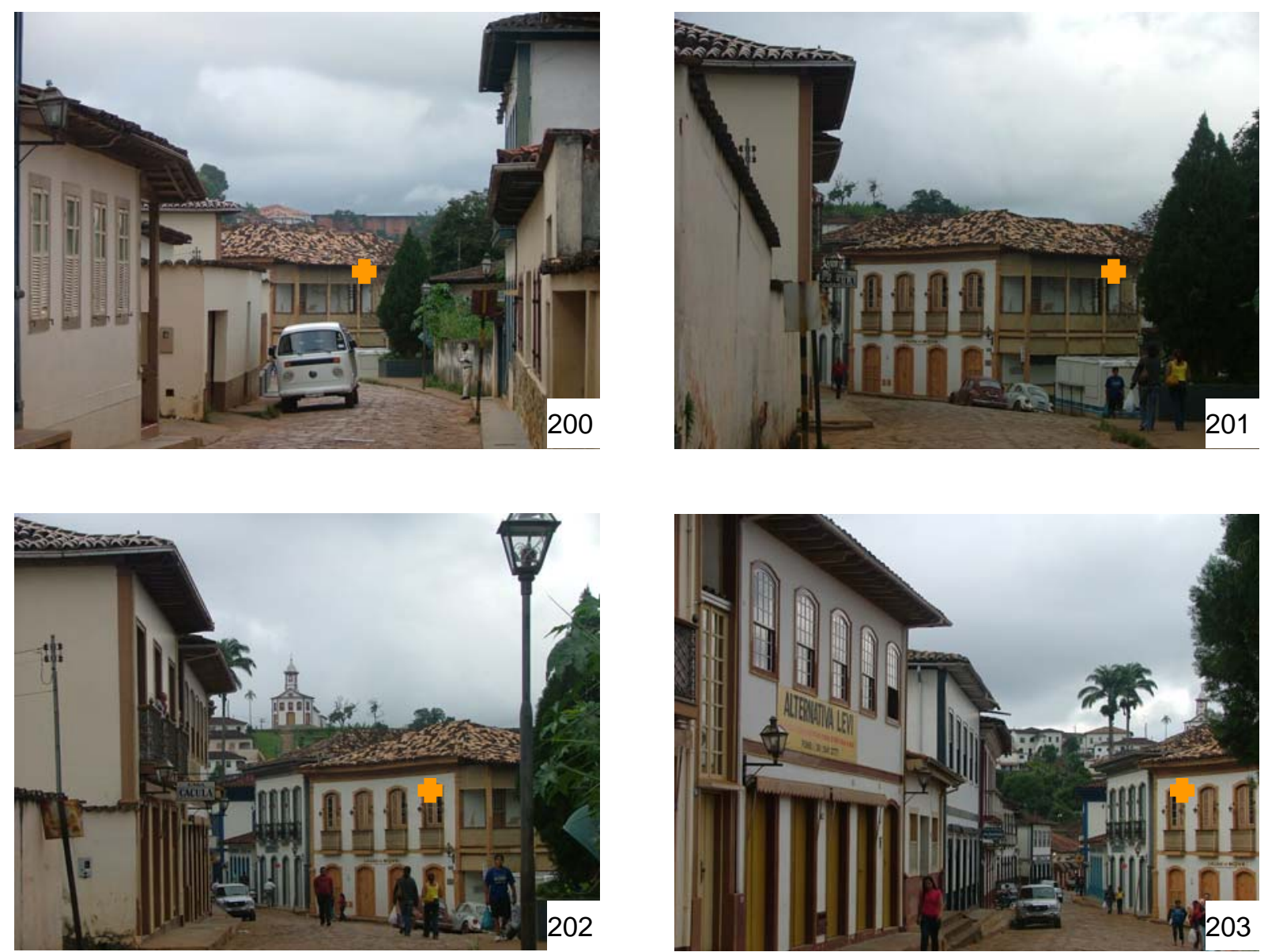

Figura 200. Figura 201. Figura 202. Figura 203. Praça Dom Epaminondas// lacuna da Igreja da Purificação// rua Nagib Bahamed passando à rua Antônio Honório Pires - marcação de edificação de referência no movimento do observador.

Após a praça Dom Epaminondas, o caminho nos conduz à praça João Pinheiro conforme apresentamos em sua percepção a partir da rua Antônio Honório Pires. 
Infelizmente, neste trecho da rua Nagib Bahamed não é apenas a lacuna da igreja da Purificação que se faz presente, mas também outras graves lacunas decorrentes da eliminação de três casinhas térreas e da transformação do telhado de duas águas para quatro (alterando significativamente a sua volumetria) de um sobrado contíguo a elas (Figura 205). A gravidade de tudo isso é potencializada, uma vez que essas transformações estão praticamente na mesma região da lacuna da igreja da Purificação - cada caso de um dos lados da rua (Figura 206 e Figura 207).

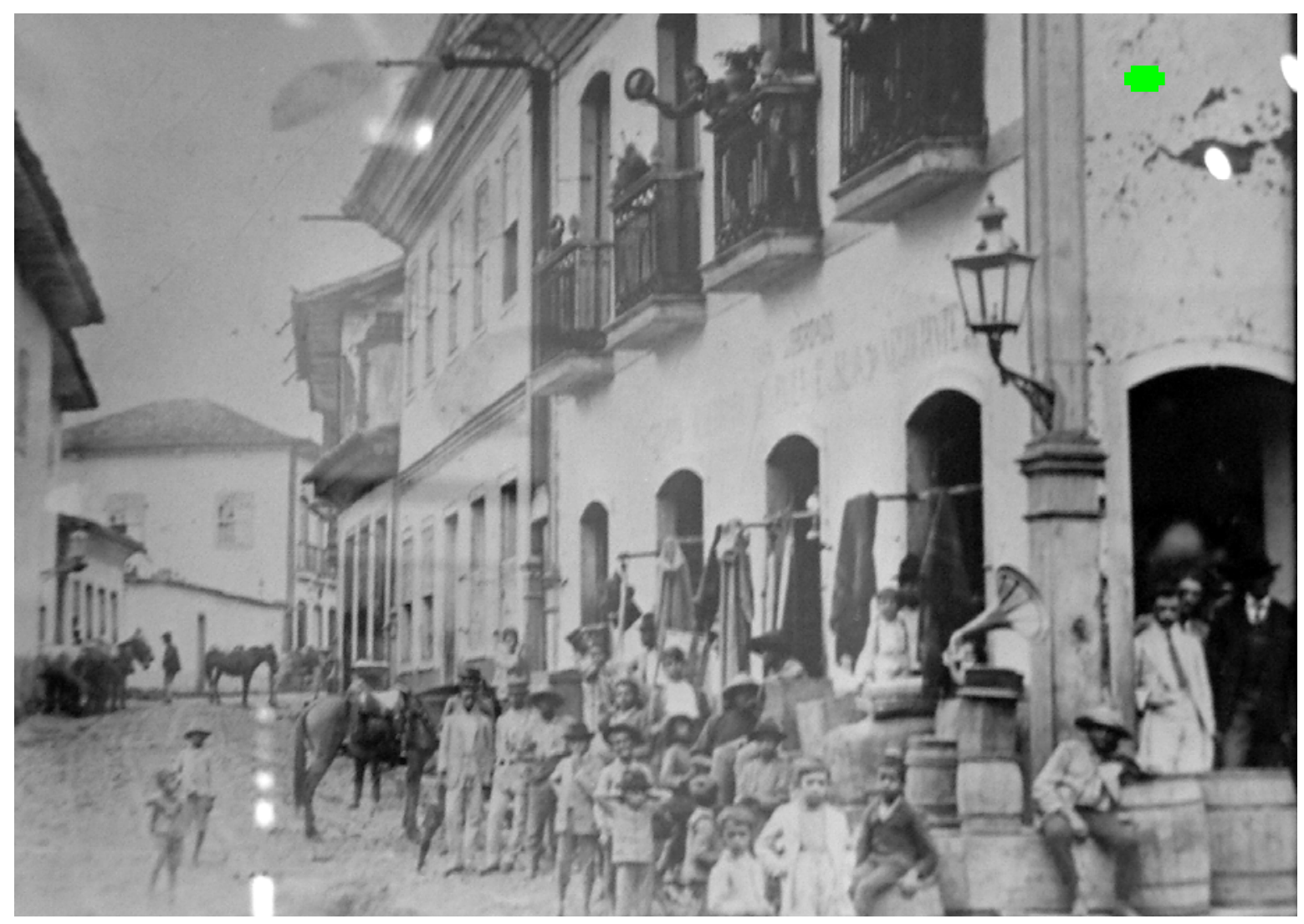

Figura 204. À esquerda, parte da fachada lateral da igreja da Purificação // rua Nagib Bahamed observador vindo da praça João Pinheiro, localizado na rua Antônio Honório Pires // marcação de edificação para referência.

Fonte: IPHAN (2006) 


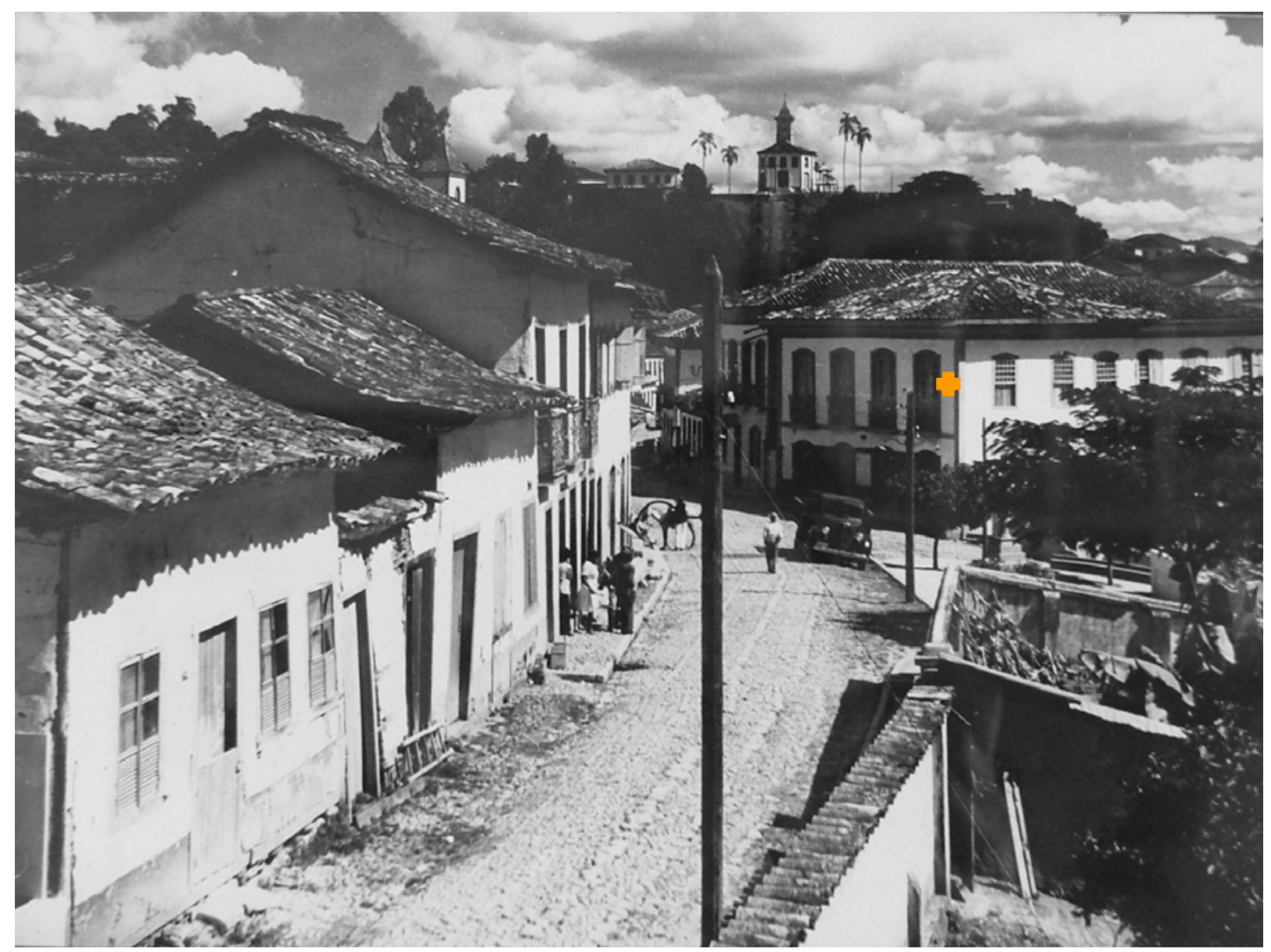

Figura 205. Lacuna da igreja da Purificação e à esquerda edificações térreas, atualmente inexistentes.

Fonte: IPHAN (2006)

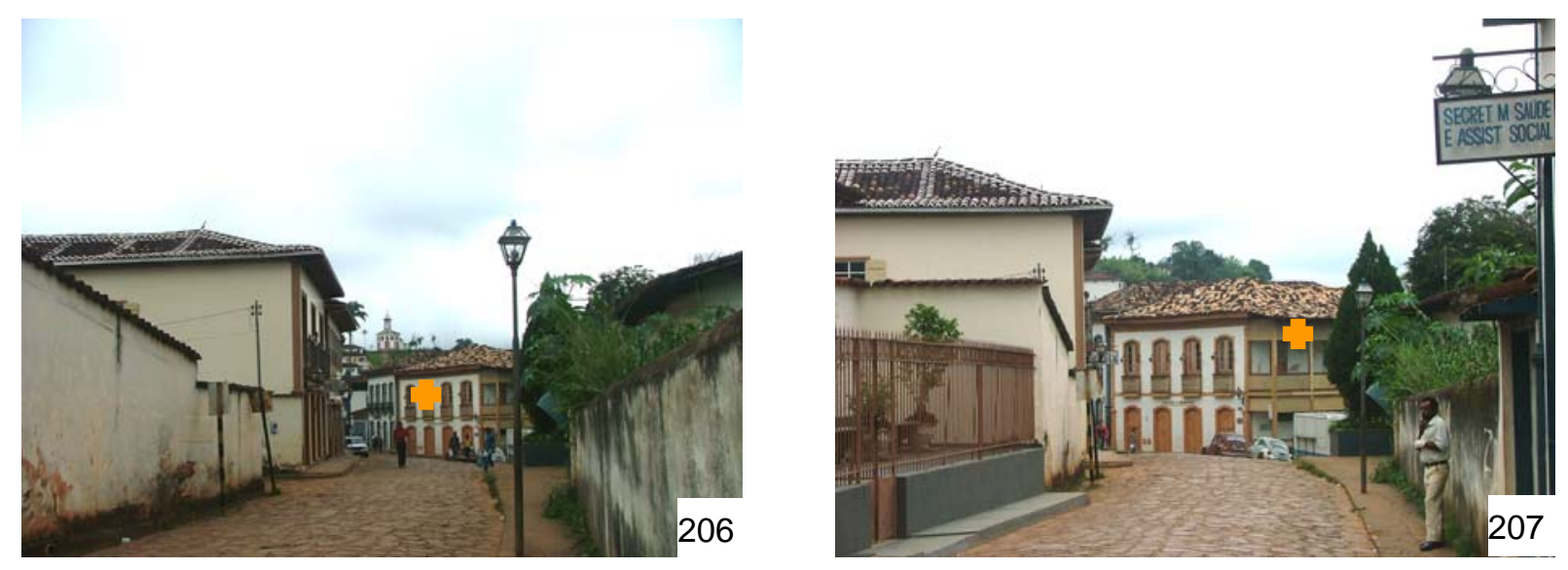

Figura 206. Figura 207. Lacuna da Igreja da Purificação e casas térreas mostradas na Figura 205. 
Considerando, portanto, que ocorre um amplo espaço "vazio" e com acréscimos na área das lacunas da igreja da Purificação e edificações térreas no ambiente que envolve a denominada praça Dom Epaminondas, acreditamos que cabe aqui, primeiramente, ilustrar tal realidade e, posteriormente, discuti-la. Deslocando a estrutura de apresentação adotada por acessos que chegam e partem das praças.

\section{A percepção da Praça Dom Epaminondas: Pela rua Antônio Honório Pires}

Uma das possibilidades de chegar à praça Dom Epaminondas (onde culminaria na fachada principal e lateral esquerda da igreja da Purificação), se faz partindo da praça João Pinheiro pela rua Antônio Honório Pires (Figura 208).

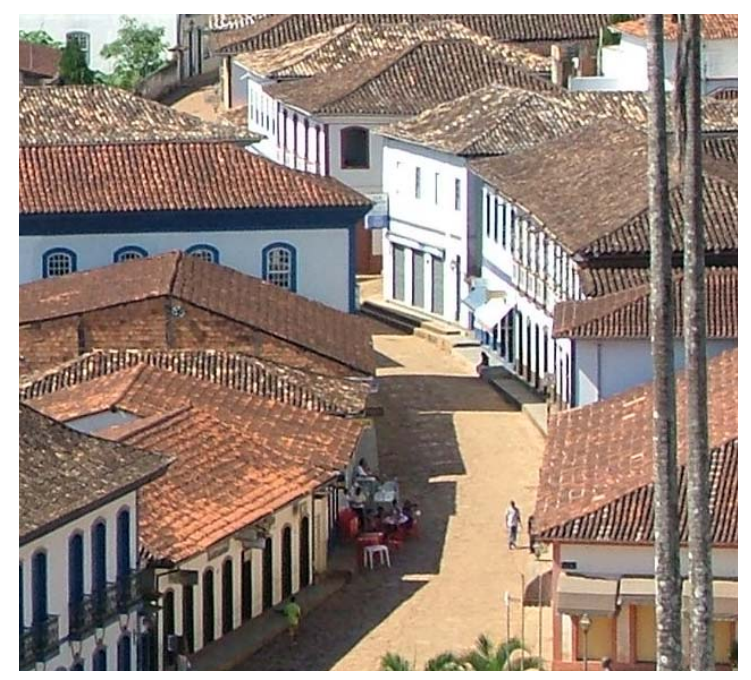

Figura 208. Rua Antônio Honório Pires iniciando na praça João Pinheiro em direção à praça Dom Epaminondas

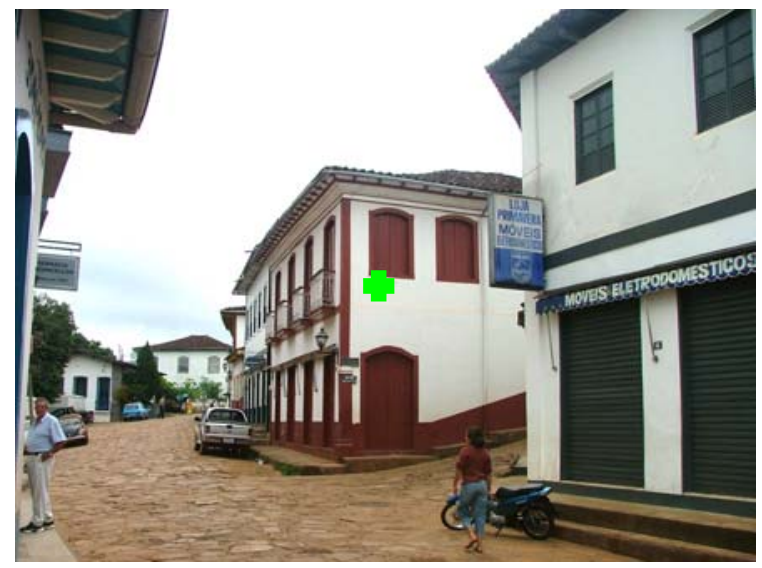

Figura 209. Rua Antônio Honório Pires acessando a praça Dom Epaminondas 

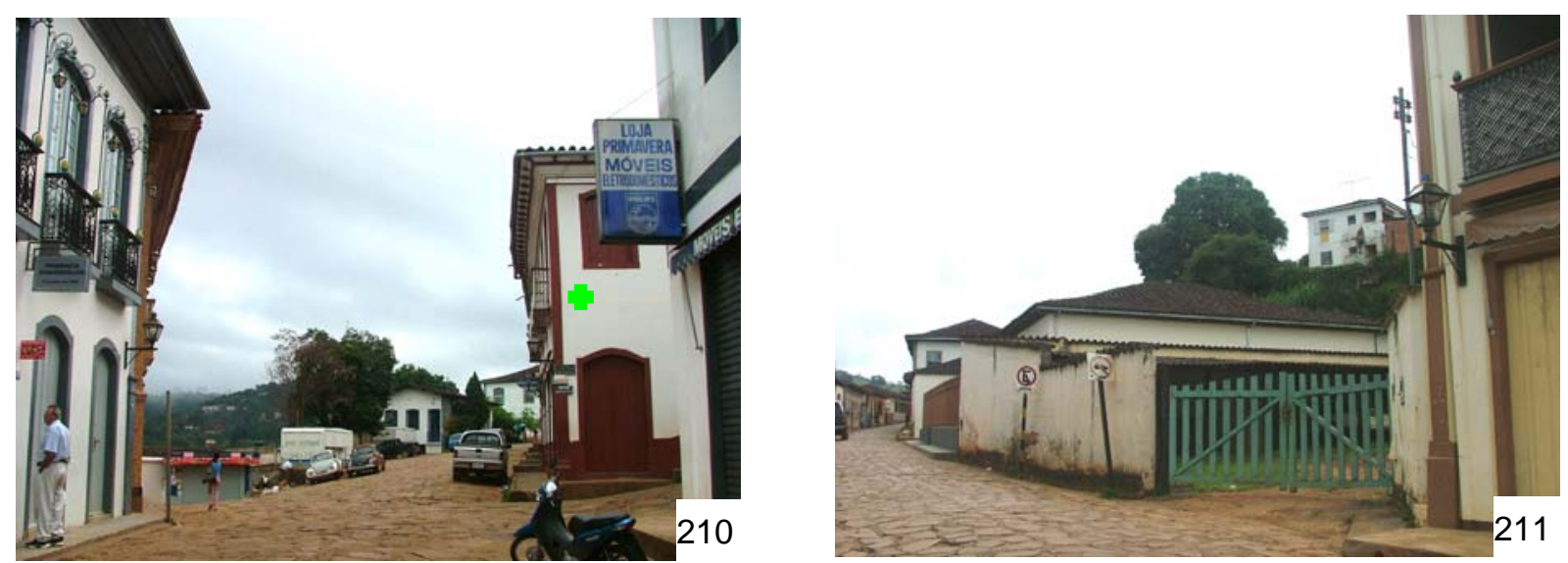

Figura 210. Figura 211. Lacuna da Igreja da Purificação - praça Dom Epaminondas e lacuna das casas térreas mostradas na figura 205 - rua Nagib Bahamed
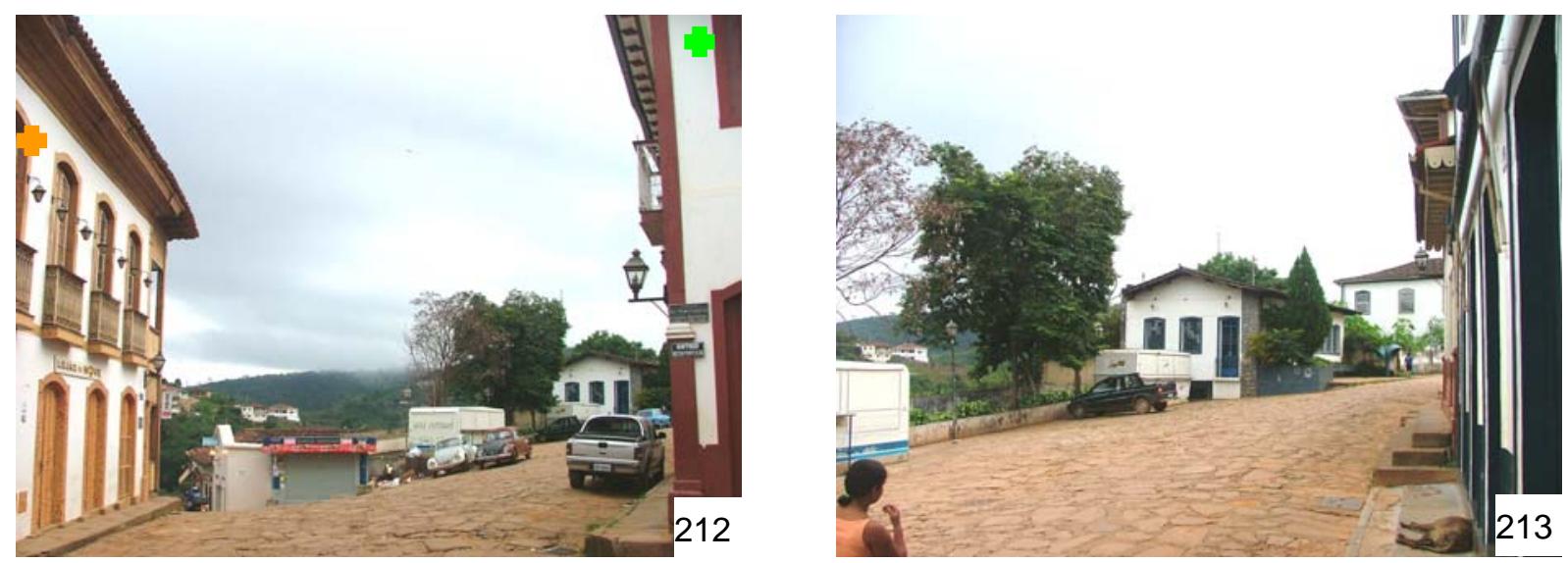

Figura 212. Figura 213. Lacuna da Igreja da Purificação (denominada praça Dom Epaminondas) observador vindo da praça João Pinheiro

Como podemos observar pela Figura 208, o percurso entre a praça João Pinheiro e a praça Dom Epaminondas é muito curto, não havendo a construção de expectativa ou descoberta. O caminho nos leva a prosseguir pela rua Antônio Honório Pires, que passa a ser denominada Nagib Bahamed, sem nenhuma indicação urbana para esta alteração (Figura 209). Por isso, talvez, tradicionalmente 
esta via era denominada simplesmente de a rua de Cima (aquela acima da Matriz, acima da rua Direita).

E, quando nos deparamos com a praça Dom Epaminondas, não vemos uma praça com suas composições artísticas, formais, como é o imaginado. Ao contrário disso, encontramos um vazio, uma interrupção na imagem, na figura constituída pelo espaço visual determinado pela paisagem urbana (Figura 212 - parece um "buraco" onde vamos cair).

\section{A percepção da praça Dom Epaminondas: a partir da rua Aferes Luis Pinto}

Outro importante caminho de entrada na praça Dom Epaminondas (que nos conduz para onde estaria a fachada principal da igreja da Purificação) é o que parte do cruzamento entre a antiga rua Direita (rua Alferes Luiz Pinto) e rua da Cadeia (Figura 214 e Figura 215). A partir deste cruzamento de vias, percebe-se que em um último plano ocorre algum tipo de interseção, mas nada que não indique o limite final de uma travessa, que rompe perpendicularmente as curvas de níveis para ligar a rua Direita à rua de Cima (Figura 214).

Verificamos que, ao seguir em direção à praça Dom Epaminondas, somos conduzidos à rua Antônio Honório Pires rumo à praça João Pinheiro (Figura 221). 
Mesmo com a ausência do volume de escala monumental, que era a arquitetura da igreja da Purificação, onde podemos identificar uma banca de revistas no local da escadaria e fachada principal da antiga igreja (Figura 217 à Figura 220). Mas isso não é o mais importante, e sim como o espaço se comporta atualmente diante da realidade que representa. Percebemos que a força da definição dos caminhos, das ruas e travessas sustenta a condição espacial adequada ao ambiente em questão.
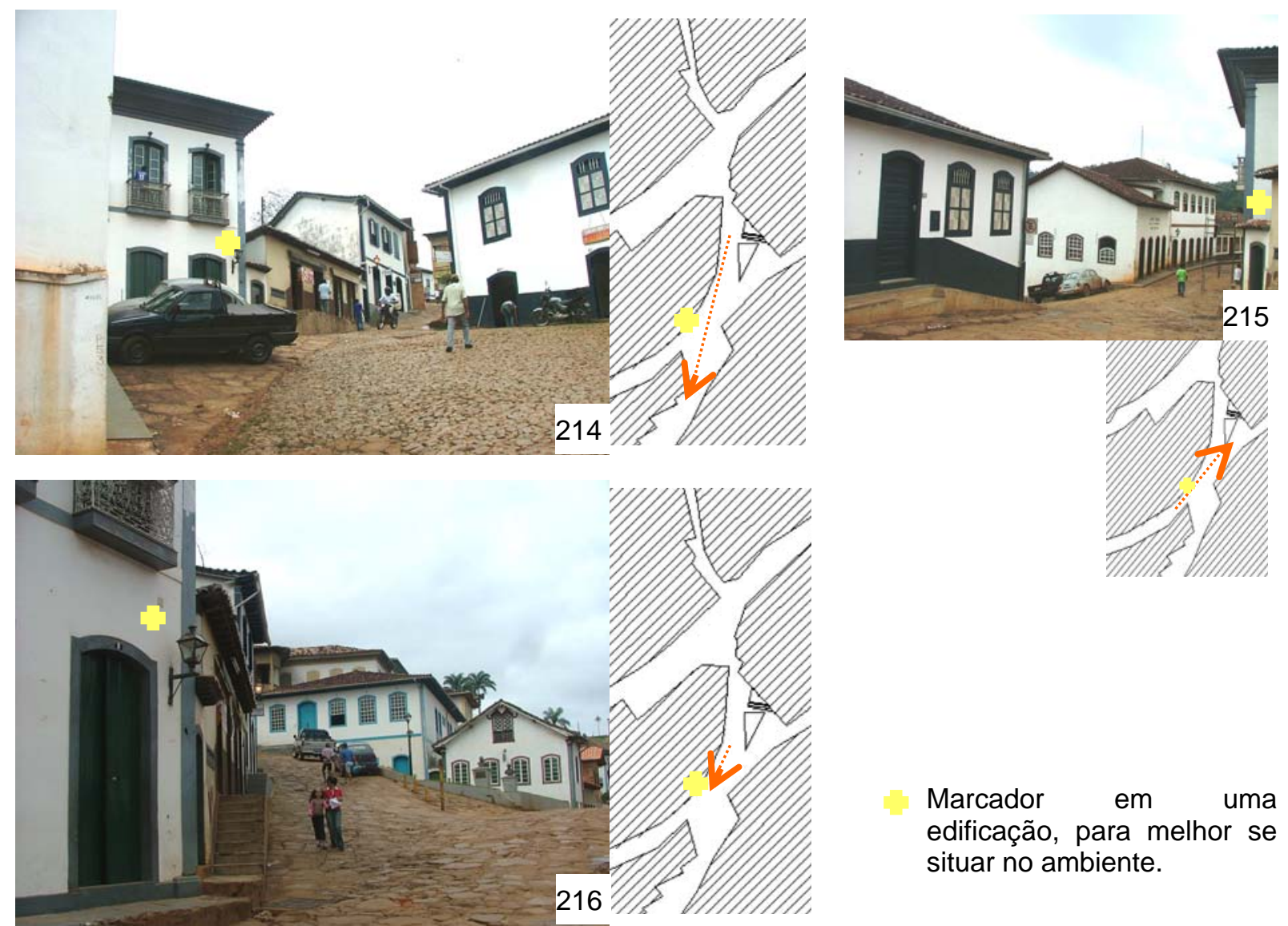

Marcador em uma edificação, para melhor se situar no ambiente.

Figura 214. Figura 215. Figura 216. Acesso à praça Dom Epaminondas a partir do cruzamento da antiga rua Direita e da antiga rua da Cadeia (foto com respectivo mapa de posição do observador)

Acreditamos que a praça Dom Epaminondas, mesmo sem a igreja da Purificação, continue se impondo como região de conexão da igreja Matriz de Nossa 
Senhora da Conceição e praça João Pinheiro com asi Nossa Senhora do Carmo e Santa Rita (Figura 222). É evidente a gravidade da lacuna da igreja da Purificação, mas o fato de ser um vazio de escala não harmônica com o ambiente urbano nos indica providências não para mudá-lo, mas para responder à demanda que ele naturalmente indica (Figura 223).
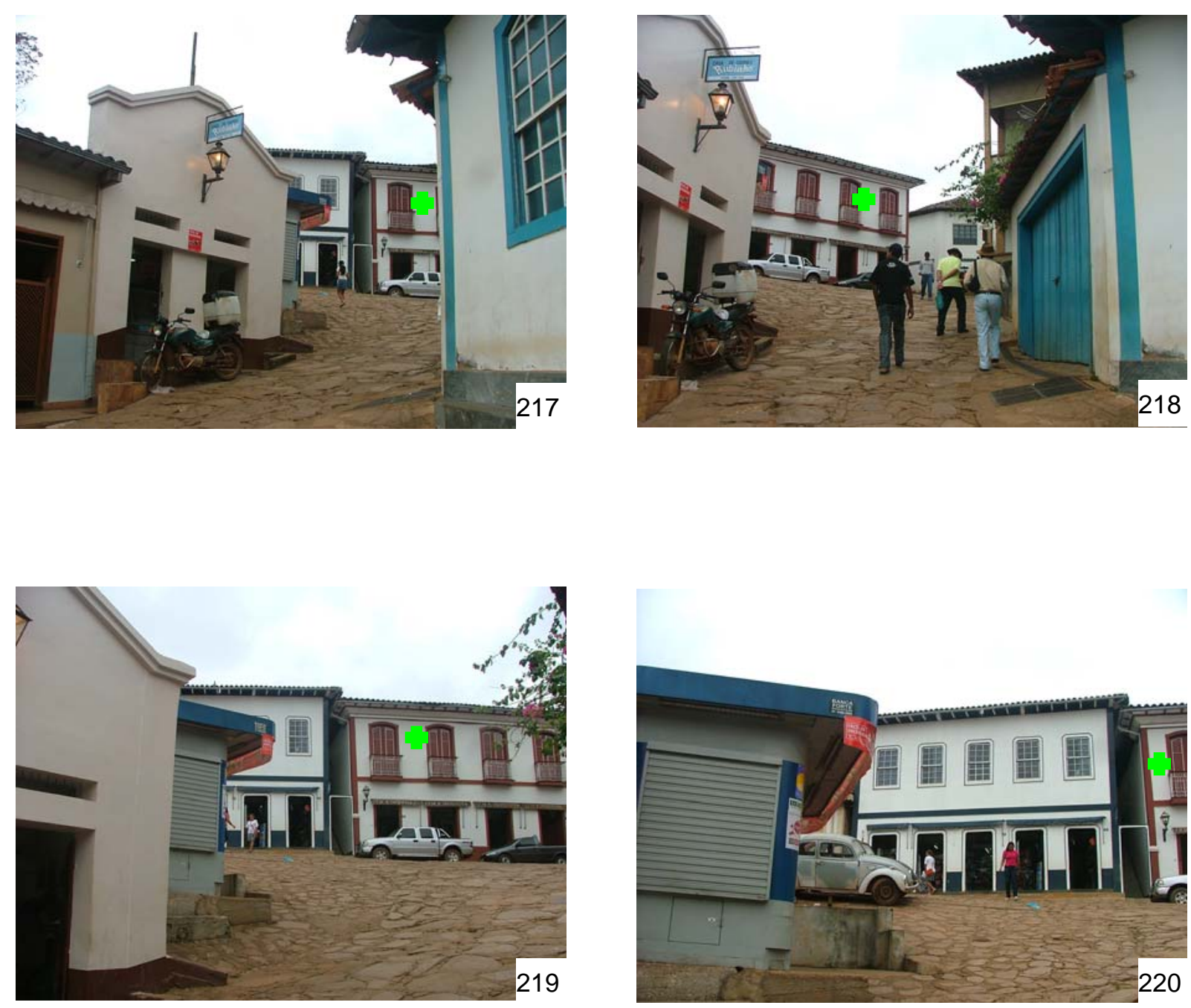

Figura 217. Figura 218. Figura 219. Figura 220. Acesso à praça Dom Epaminondas a partir do cruzamento da antiga rua Direita com a rua da Cadeia. 


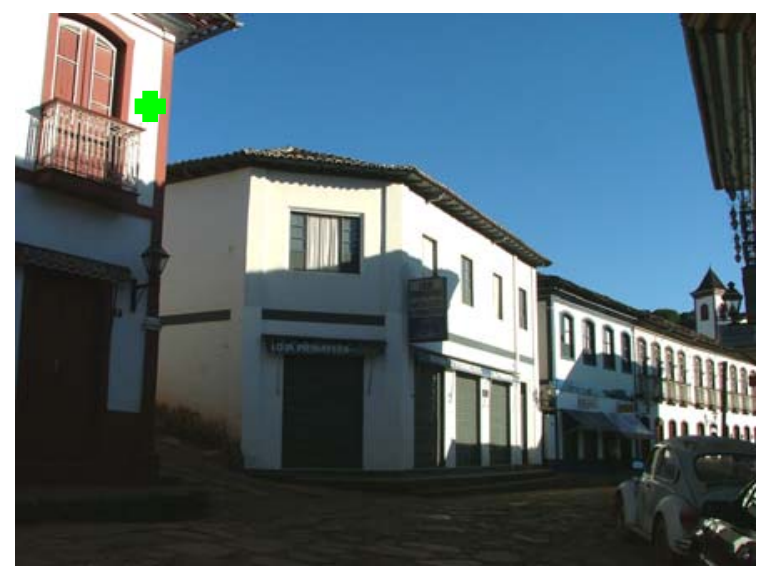

Figura 221. praça Dom Epaminondas, onde poderíamos entender como o largo da igreja da Purificação, conforme figura

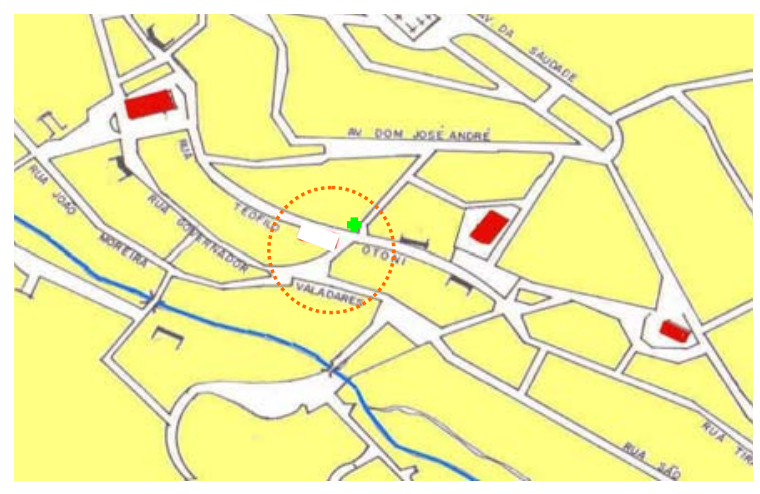

Figura 222. Localização da lacuna da igreja da Purificação em relação às igrejas Matriz, Nossa Senhora do Carmo Santa Rita.

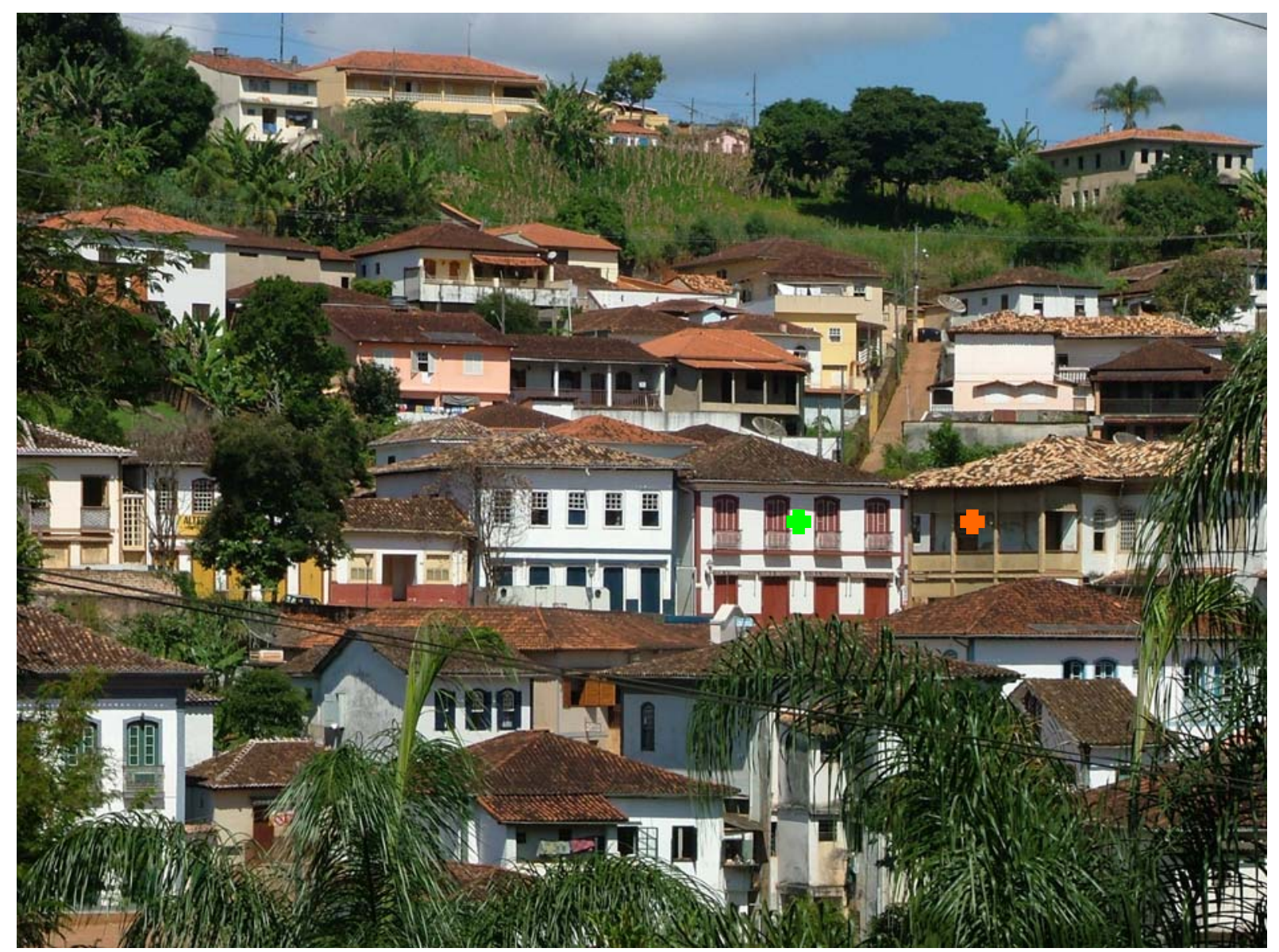

Figura 223. Vista panorâmica do conjunto urbano onde se localiza a praça Dom Epaminondas marcação, para referência ao observador, das edificações conforme figuras anteriores. 


\section{Capítulo 3 - O restauro urbano}

Este capítulo evidencia a resposta à possibilidade de um restauro urbano, a partir da interpretação e estudo analítico e crítico da "Teoria da Restauração" de Cesare Brandi, tradução de Beatriz Kühl, publicada em 2005. Identificamos apontamentos feitos por Brandi (2005), que, segundo onde entendemos, tratam da questão da restauração adequada ao ambiente urbano. Utilizamos ainda outros escritos de Brandi (2005) com o intuito de reforçar o entendimento quanto à possibilidade de um restauro urbano. A partir desses instrumentos, verificamos tal possibilidade, tendo como objeto principal, as demandas identificadas em praças de Serro, estudadas com a devida crítica e respeito à instância histórica, estética, no reconhecimento delas enquanto obra de arte.

Trata do encerramento das análises e reflexões pretendidas para esta pesquisa, dentro do objetivo principal pretendido de verificar a possibilidade de um restauro urbano da cidade patrimônio cultural, tendo como estudo de caso o ambiente urbano de Serro. 


\subsection{A restauração da cidade e a Teoria brandiana}

Giovanni Carbonara (2002, tradução da autora) em seu livro Avvicinamento al Restauro afirma estar convencido de que "a linha mais correta e mais adequada para a defesa do patrimônio cultural seja a crítica-brandiana, porque se mostra atual e possibilita a extensão do conceito de 'bem cultural' ", que acontece a partir do rápido consumo por via de "relíquias materiais do passado", que são percebidas atualmente em uma nova estratégia quantitativa, caracterizada por uma necessária e ampla tutela, com especial empenho de pesquisas, da documentação históricotestemunhal dessas relíquias.

O apoio conceitual e propositivo impregnado por Brandi (2005) na Teoria da Restauração está fundamentado através da estética e da história, e para ele os procedimentos de restauro estão atrelados ao reconhecimento que possamos fazer da obra de arte como tal e enquanto documento histórico, de maneira conjunta; portanto, como dado cultural, consubstanciado na análise da obra em seus aspectos físicos e como imagem figurada, sem deixar de considerar sua transformação ao longo do tempo. Para isso, Brandi (2005) serve-se de instrumentos de base filosófica além de fundamentar-se na história, crítica da arte e estética.

Para Beatriz Kühl (2006), o reconhecimento da teoria de Brandi representa uma aplicação de medidas, "com raízes na fenomenologia, profunda e complexa de 
deixar-se penetrar na obra de arte e no processo que a produziu, examinando-a em sua plenitude formal, buscando, por assim dizer, sua realidade ontológica".

Disto resulta o entendimento de que, para Brandi (2005), uma obra de arte "não se compreende, se reconhece", uma vez que se trata da totalidade do processo que a produziu. Esse modo particular do existir da obra é denominado por Cesare Brandi (2005) como "astanza", que representa a especial condição do indivíduo no mundo do objeto, e acontece sempre que a obra é percebida, havendo possibilidade contínua de seu reconhecimento no decorrer do tempo. E para Kuhl (2006) "é esse reconhecimento que faz da obra de arte uma obra de arte, processo que não é imediato, mas extremamente complexo, reconhecendo o objeto na plenitude de sua herança formal", de sua estrutura em dimensão ampla e fundamental relativa ao ser em si mesmo.

Para Cesare Brandi (2005), com a "astanza" o reconhecimento da obra de arte é "duplamente singular", vinculado ao indivíduo que o efetua. Entretanto, isso não quer dizer que restauração seja ato relativo ao próprio indivíduo, uma vez que Brandi (2005) vincula o restauro a um processo histórico-crítico. Se retomarmos a definição de restauração, perceberemos a condução de um trabalho multidisciplinar - consistência física e dúplice polaridade estética e histórica -, ainda que a parte de contribuição direta para a obtenção do resultado pretendido seja desempenhada por uma única pessoa.

E, neste trabalho de distanciamento do empirismo, Brandi (2005) enfatiza a partir da utilização de procedimentos vinculados à crítica de arte, estética e história 
que restauração não é apenas reconhecimento, é o "momento metodológico" deste reconhecimento da obra de arte, agora ampliada ao conceito de bem cultural, mas focado na "sua consistência física e na sua dúplice polaridade estética e histórica", comprometido à transmissão destes bens para as gerações futuras. Percebemos que, por se fundamentar na relação dialética entre as "instâncias" estéticas e históricas de uma ou mais obras, as proposições da Teoria da Restauração exigem significativo esforço interpretativo caso a caso.

Apesar de alguns profissionais ainda colocarem dúvidas sobre a aplicabilidade dos princípios brandianos à arquitetura, identificamos apontamentos de nítida evidência de a Teoria da Restauração de Cesare Brandi ser adequada não só para arquitetura como para o espaço urbano. Ressaltamos que esta verificação se ateve apenas na Teoria brandiana, não levamos em consideração outros escritos de Brandi neste momento das análises. Estudamos publicações diversas desta, desenvolvidas por ele, em alguns momentos no intuito de reforçar determinados entendimentos. Cabe ainda lembrarmos que a Teoria da Restauração está organizada em "capítulos", textos reunidos por Cesare Brandi, que devem ser entendidos e estudados em conjunto; não é possível uma adequada interpretação tratando-os separadamente.

Brandi (2005), por meio do texto "Princípios para a Restauração dos Monumentos", responde de imediato às indagações daqueles que entendem a arquitetura e a cidade fora do escopo artístico decorrente de sua funcionalidade, e dinâmica de transformação ambiental, esclarecendo que 
para a restauração dos monumentos valem os mesmos princípios que foram explicados para restauração das obras de arte, [...] dado que a arquitetura, como tal, é obra de arte, como obra de arte goza da dúplice e indivisível natureza de monumento histórico e obra de arte, e o restauro arquitetônico recai também sob a instância histórica e a instância estética (BRANDI, 2005, p.131).

Entretanto é fundamental que estejamos atentos à especificidade da estrutura formal da arquitetura, que é diferente das obras de arte entendidas a partir da experiência da observação, como pintura (exceto a rupestre), escultura, pois conforme esclarece Brandi (2005), a distinção básica entre arquitetura e demais artes é percebida na espacialidade que se realiza em uma dada figuratividade, e que não vem até a obra a partir do exterior, mas como função da sua própria estrutura. E assim podemos perceber a condição da cidade que, formalmente, é constituída de arquitetura, e pode ainda ser entendida como arquitetura.

Brandi (2005) chama atenção para o importante entendimento da diferença na arquitetura em um caso de restauro, onde a questão não diz respeito à essência da arquitetura, diversa ou não, da obra de arte, mas ao fato de que "na arquitetura a espacialidade própria do monumento é coexistente com o espaço ambiente em que o monumento foi construído" (BRANDI, 2005). Conclui-se, portanto, que "a dimensão interior-exterior exige a conservação do espaço ambiente em que o monumento foi construído". Conseqüentemente, entende-se melhor que sob este aspecto a questão pode ser vista sob a ótica do monumento, ou do ambiente que, "além de estar ligado de modo indissolúvel ao próprio monumento do ponto de vista espacial, pode constituir, por sua vez, um monumento, de que o monumento em questão constitui elemento" (BRANDI, 2005). Delineia-se a questão da arquitetura como exterior, que 
tange eventuais operações de restauro, de onde podemos compreender com clareza a questão para o contexto urbano.

Dentro do texto da Teoria da Restauração (não se considerando outros escritos), Brandi (2005) indica situações em que podemos relacionar a aplicabilidade de sua teoria para a cidade. Consideramos de destaque os apontamentos referentes ao caso da ruína, da inserção da arquitetura moderna em ambiente antigo e do refazimento do Campanário de São Marcos em Veneza. Nessas situações, fica evidente a presença da dimensão espacial do ambiente urbano no processo de restauro.

Ao se referir à ruína, Brandi (2005) tem o cuidado de esclarecer o seu conceito técnico de historicidade "como ponto mais remoto a que poderíamos remontar, no rio de ação do restauro, em relação àquilo que revelasse de atualização humana"; disto ele coloca como prerrogativa que tal remanescente ligado à atividade humana tivesse sido também obra de arte. Enfatiza, ainda, que quando a artisticidade permanece em um produto da atividade humana, por mais que ele esteja mutilado, não se deve denominá-lo de ruína e vice-versa. Caso tais vestígios estejam de fato perdidos, não há mais artisticidade, mas apenas historicidade. Daí, Brandi (2005) conclui que ruína é "qualquer remanescente de obra de arte que não pode ser reconduzido à unidade potencial, sem que a obra se torne uma cópia ou um falso de si própria". Portanto, ele passa a evidenciar ruínas que não podem ser integradas e sim conservadas, resultando desta afirmação o entendimento de que, estando a ruína sem condições de ser reconduzida à unidade potencial, contrapõe-se à determinação positiva no qual o "remanescente de obra de 
arte que, sem poder ser reconduzida à unidade potencial, se associe a outra obra de arte, de que recebe e em que impõe uma particular qualificação espacial, ou faz adequar a si uma dada zona paisagística" (BRANDI, 2005).

Brandi (2005) afirma que, quando se tratar de uma obra de arte em que a ruína foi absorvida, é esta "segunda" obra de arte que deve prevalecer. Destacamos, no caso, o reconhecimento do espaço ambiente entendido como prioritário em uma obra de restauração que envolva ruína, quer seja arquitetura, quer cidade.

O historiador e crítico de arte afirma que, em se tratando de ruínas "deveria conservar-se não apenas a ruína do monumento, mas o âmbito que era a ela conexo e que era, pela ruína, qualificado" (BRANDI, 2005). Assim, ao assumir a importância que a ruína possui de chamar para si o ambiente que a envolve, ou o espaço que define sua vizinhança, Brandi (2005) enfatiza esta capacidade de sustentação da síntese paisagística e urbanística onde a ruína está inserida, em prejuízo da própria consistência da ruína, devendo ela ser entendida como um qualificador da paisagem ou zona urbana, passando a completar o ambiente de onde é reconhecida a sua vitalidade enquanto ruína.

é por isso um erro crer que toda coluna despedaçada possa ser reerguida e recomposta de modo legítimo quando, ao contrário, o ambiente onde isso deveria acontecer já atingiu, historicamente e esteticamente, uma acomodação que não deve ser destruída nem para a história nem para a arte (BRANDI, 2005, p.82).

Conforme o autor, uma vez ruína e associada a outra obra de arte, esta passa então a ser o objeto principal das análises. É ressaltada por Brandi (2005) a importância do espaço ambiente seja ele paisagístico - obra envolvida pela natureza 
- ou urbanístico, na conservação da ruína. Cesare Brandi faz a inserção da cidade na demanda de preservação de uma obra de arte; e, no caso da ruína, a obra de arte que a recebe passa a ser a de primeira análise. Entendemos que, neste caso, possa ser a paisagem urbana.

Podemos identificar como outra questão urbana na Teoria brandiana aquela referente ao "refazimento do Campanário de São Marcos" em Veneza. Esta reflexão acontece a partir das discussões quanto à permanência ou não de refazimentos que devem ser conservados quando alcançar uma nova unidade artística; e mesmo nos casos que representem "condenável repristinação ou uma nova adaptação" (BRANDI, 2005), devem ser mantidos, pois o contrário poderia levar à destruição parcial de alguns aspectos do monumento. Brandi (2005) enfatiza que neste caso o refazimento do campanário de São Marcos, entendido por ele "antes uma cópia do que um refazimento, mas funciona como refazimento para o ambiente urbano que completava" -; a cópia é um falso histórico e um falso estético e, por isso, "pode ter uma justificação puramente didática e rememorativa, mas não se pode substituir sem dano histórico e estético ao original" (BRANDI, 2005).

Dessa reflexão ocorre a clareza da abordagem urbana por Cesare Brandi. Para ele "no caso do campanário de São Marcos, aquilo que importava era um elemento vertical na praça; a reprodução exata não era requerida a não ser pelo sentimentalismo bairrista" (BRANDI, 2005). E tudo isso se torna mais evidente quando Brandi utiliza o ditado "como era, onde estava" lembrando que se trata da “negação do próprio princípio da restauração", representando uma "ofensa à história e um ultraje à estética" (BRANDI, 2005). 
Neste caso, entendemos que, ao afirmar que o "refazimento do campanário" se trata do "refazimento do ambiente urbano", Brandi (2005) está reconhecendo no ambiente urbano, na cidade, a condição material, estética, histórica, onde a crítica remete ao conceito de restauração. Entendemos que Brandi (2005) trata com naturalidade a utilização dos princípios de restauração, tendo como exemplo a cidade de Veneza.

Outro importante indicativo que relacionamos quanto aos apontamentos urbanísticos presentes na Teoria brandiana se refere à abordagem de preservação de um único monumento denominado "Vila Giulia", em Roma, onde Brandi (2005) evidencia a manutenção da unidade perspéctica da rua, com destaque para massa, cor, altura, admnistrando - em casos de necessária inserção - uma nova construção onde existia "a casa, a casinha acomodada" (BRANDI, 2005). Entretanto, no caso de inserção em ambiente monumental com "uma moderna [arquitetura] de igual massa, altura, cor", o historiador da arte é categórico e afirma que não poderá "uma construção que tem o direito de se chamar arquitetura" destruir um status quo. Acreditamos que estas considerações permitem facilmente estabelecer um paralelo com nosso objeto de estudo. A Figura 224 ilustra, a nosso ver, muito apropriadamente esse entendimento de Cesare Brandi (2005), quando registra a interrupção da forma urbana consolidada na cidade de Diamantina, pela inserção de edificação modernista, com escala, forma, implantação, diversos do padrão urbanístico existente, criando forte ruptura na percepção da imagem do conjunto.

dada a espacialidade contrastante que personifica a arquitetura moderna, a inserção de uma verdadeira arquitetura moderna em um contexto antigo é inaceitável. Portanto, de nenhum modo, em se tratando ou não de 
arquitetura, pode-se conceder a alteração de um ambiente arquitetônico antigo com a substituição das partes que constituem seu tecido conectivo que, mesmo se amorfo, é sempre coevo e historicamente válido (BRANDI, 2005, p.108).

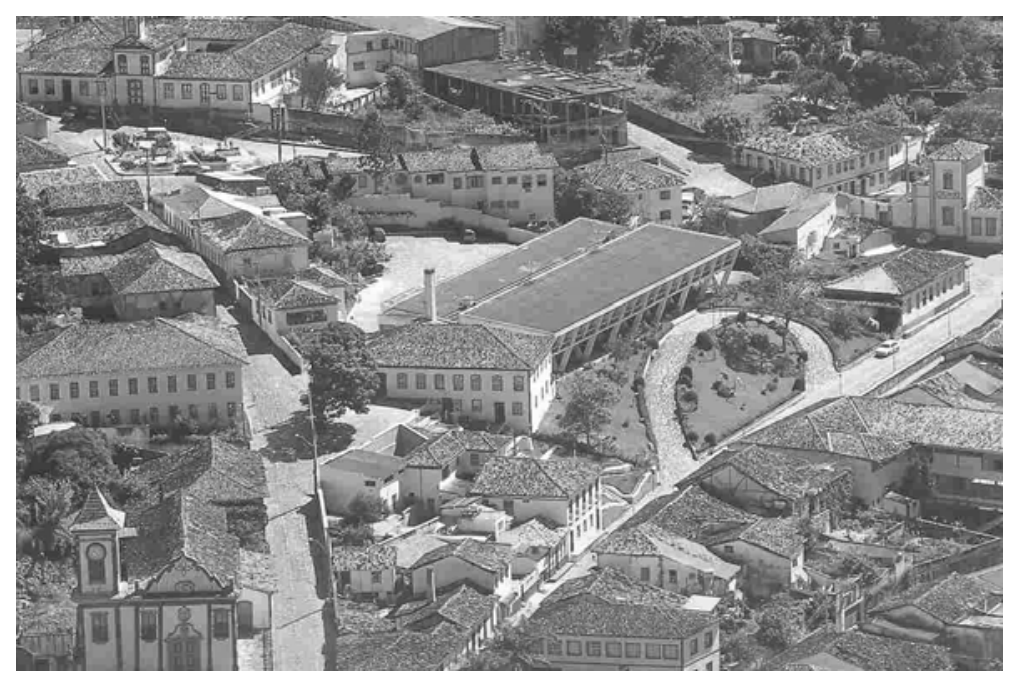

Figura 224. Relação de escala urbana entre edificação de arquitetura modernista e a cidade de Diamantina.

Fonte: IPHAN (2006)

Acreditamos, portanto, que, com tais abordagens, Cesare Brandi (2005) indica com clareza que a Teoria da Restauração se aplica ao ambiente urbano e, neste sentido, torna-se indispensável o discernimento dos esclarecimentos de Giovanni Carbonara quanto à importância do alargamento do conceito de Bem Cultural, com o qual a Teoria brandiana se mostra atual e absolutamente contemporânea.

A Teoria da Restauração de Cesare Brandi parte de uma lógica dedutiva fundamentada em axiomas éticos e científicos. Nela expõe que o fato de se reconhecer a obra de arte como tal impõe a quem reconhece o imperativo moral da 
sua conservação também por isso, é imperioso que a análise que guia a intervenção seja muito bem fundamentada, pois somos responsáveis pelos nossos atos perante o presente e perante as gerações futuras.

Neste sentido, procuramos, por meio do estudo de caso de Serro, evidenciar tal responsabilidade ante a pretensão de se intervir na cidade. Ao compreendermos restauração como "momento metodológico do reconhecimento da obra de arte, na sua consistência física e na dúplice polaridade estética e histórica, com vista à sua transmissão ao futuro" (BRANDI, 2005), buscamos identificar em Serro o reconhecimento de sua condição artística, no âmbito físico, material, formal, onde a estética e a história se mostraram instrumentos inerentes a este próprio reconhecimento, para evidenciarmos ilustrativamente, a partir dele, a necessidade iminente de a cidade de Serro ser restaurada, dentro de um adequado e respeitoso procedimento, visando à sua coerente salvaguarda para as gerações futuras, que sobre isso possuem legítimo direito. 


\subsection{Serro para o futuro}

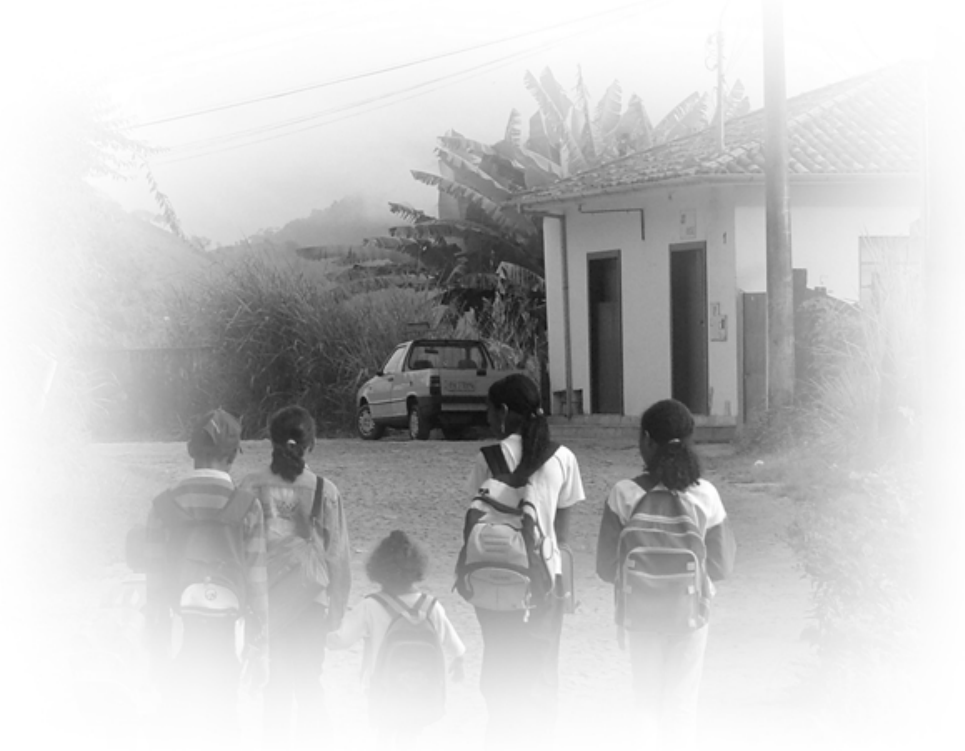

Figura 225. Crianças caminhando para a escola no Serro

Acreditamos que por todas as condições que nos permitem conhecer a cidade de Serro, sejam elas entendidas através da estética, de seus dados formais, da história, - entendendo que são características coexistentes -, ou mesmo por outros fatores, temos a convicção de que tudo isto deva continuar. Mesmo compreendendo a dinâmica das transformações urbanísticas às quais estão sujeitas as cidades na atualidade, conforme verificamos neste estudo, é possível a manutenção adequada da preservação urbana e, se for necessário, podemos recorrer à restauração como importante auxílio nesta tarefa. 
Com o apoio dos princípios artísticos de Camillo Sitte (1992), instrumentalizamos procedimentos para mapear danos formais de significativo comprometimento físico em ambientes urbanos de Serro. E, a partir do destaque de algumas situações, consideradas danosas para a preservação da cidade (apresentadas no capítulo 2), verificamos a evidência de um adequado procedimento restaurativo, em busca do resgate e ou manutenção da unidade potencial do ambiente urbano em questão, conforme preceitos de Cesare Brandi (2005).

\section{$\underline{\text { Lacunas por adição e por supressão - a teoria brandiana no Serro }}$}

Em Serro (conforme estudos demonstrados no capítulo 2 desta pesquisa Estado da forma urbana), podemos destacar, dentre as transformações ocorridas na antiga praça do Pelourinho ou da Matriz, atual praça Getúlio Vargas, desde o tombamento da cidade pelo IPHAN, a redução de sua área tradicional pela inserção de nova arquitetura; pela construção de "platô" onde ficava o Pelourinho (Figura 226 e Figura 227); pela eliminação do passadiço da Ladeira da Matriz (Figura 97, Figura 98, Figura 229, Figura 230). 

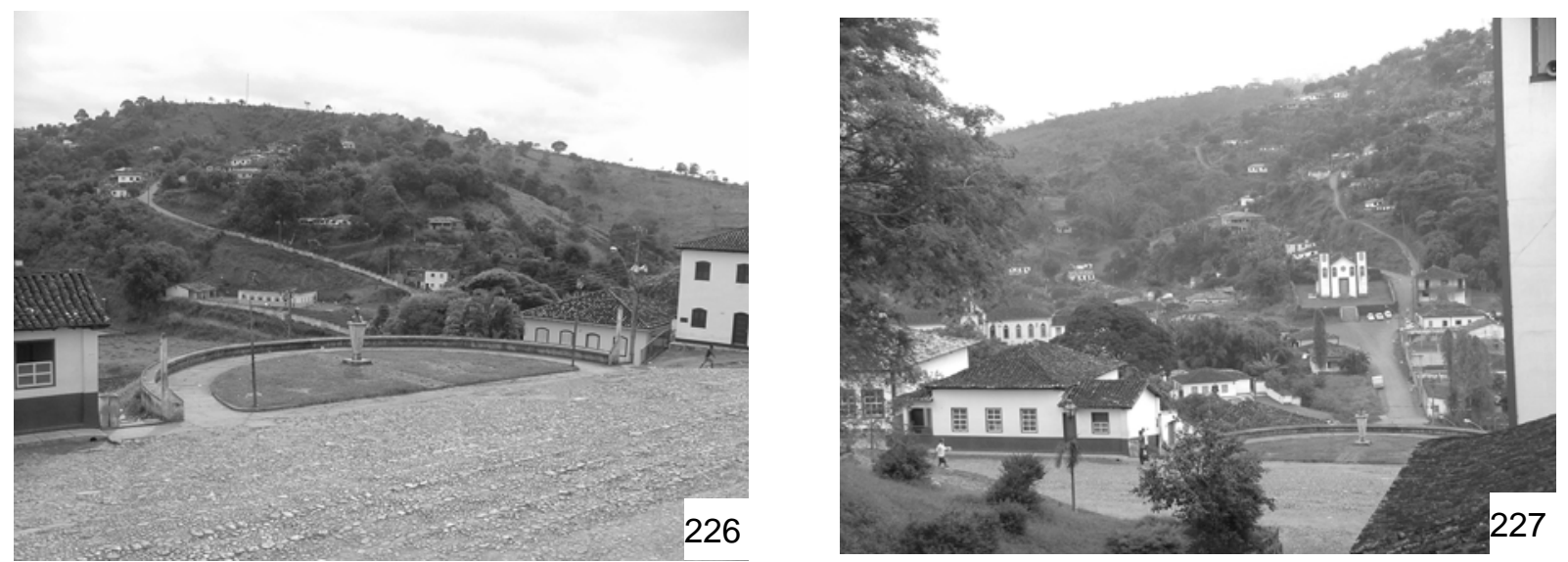

Figura 226. Figura 227. Praça Getúlio Vargas - "platô" onde ficava o Pelourinho.
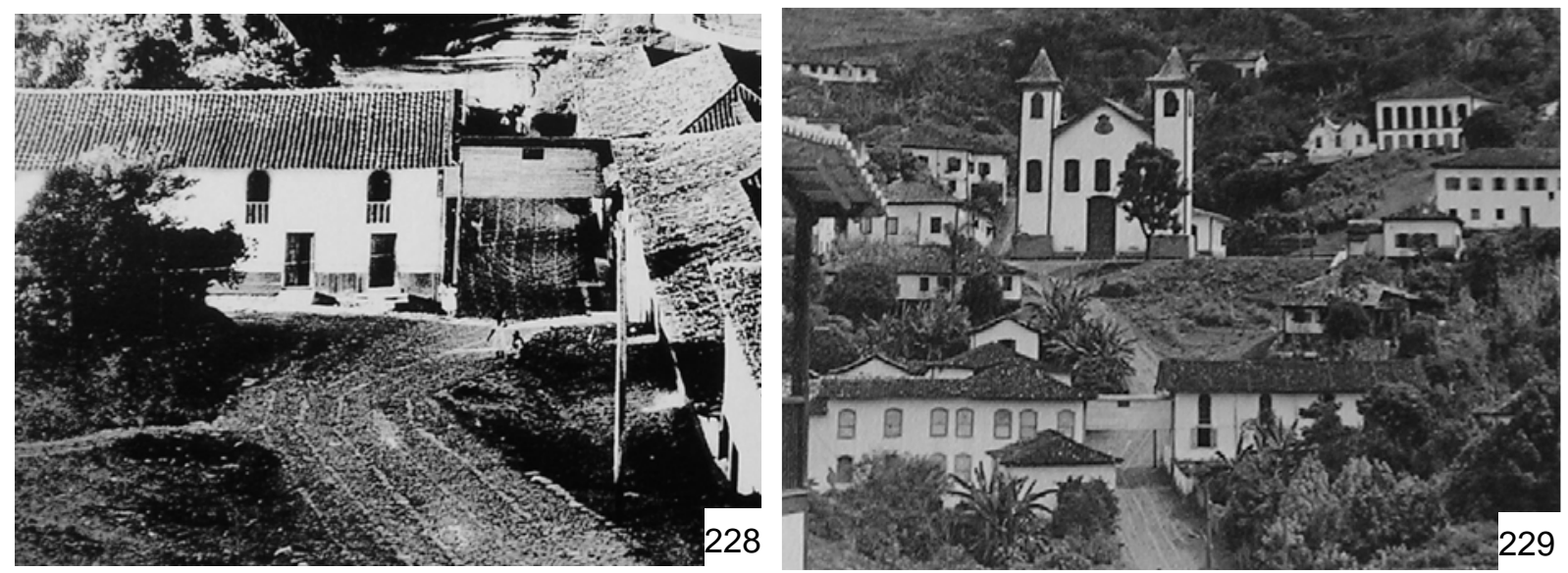

Figura 228. Figura 229. Passadiço do antigo colégio Nossa Senhora da Conceição // vista pela descida e subida da ladeira da Matriz.

Fonte: IPHAN (2006)

No caso da praça João Pinheiro, destaca-se a interrupção do beco do Carmo; a modificação de seus níveis altimétricos; o acréscimo de novos degraus para acesso ao adro da igreja de Nossa Senhora do Carmo; a marcação da "caixa" da rua em frente à praça João Pinheiro; o adensamento do ambiente que envolve a praça - 
construção de novas edificações onde havia área verde/ livre/ fundo de quintais (Figura 241 à Figura 246).

Consideramos que transformações que de fato foram incorporadas pela obra de arte devam permanecer, mas, nos casos em que representem danos, eles devem ser removidos. Brandi (2005) ressalta que o tratamento das lacunas em uma obra de arte versa sobre "uma solução, sobretudo, teórica", uma vez que o problema está conexo à própria essência da obra. Ou seja, a condição para a adequação "de cada caso a caso" não deve desconsiderar a premissa teórica.

Pensando em um tratamento para lacunas em Serro, primeiramente circunscrevemos o objeto da pesquisa. Implementando princípios da Teoria da Restauração de Brandi, aplicamos às praças - estudadas em Serro, conforme capítulo anterior desta pesquisa - um tratamento fenomenológico, submetendo-as a um especial limite. "Nós nos limitaremos a considerar a obra de arte só como objeto de experiência do mundo da vida, para nos atermos a uma expressão de Husserl" (BRANDI, 2005). Através desse posicionamento, Brandi (2005) condiciona a aceitação da obra como ela entrou no campo de nossa percepção, de nossa experiência sem indagá-la em sua essência. Esclarecemos que esta circunscrição do objeto foi realizada, no caso de Serro, com o auxílio dos princípios artísticos de Sitte (1992), que acreditamos ter possibilitado a interseção necessária ao adequado entendimento do objeto, visando sua preservação, no caso, a restauração de espaços urbanos com lacunas. 
Este especial limite circunscrito à obra de arte "está relacionado com a suspensão prévia de qualquer juízo sobre o domínio do conhecimento em consideração" (KÜHL, 2006). Para Brandi (2005), a obra de arte chega até nós como "um circuito fechado", representando algo em que temos o direito de intervir apenas para conservá-la o mais íntegra possível, ou para reforçá-la "em sua estrutura material periclitante", se necessário. Nesse sentido, o historiador da arte esclarece que a conservação da obra de arte na sua integridade "deve limitar-se a intervir na obra só porque, por indevidas intervenções ou por ação do tempo a obra tenha sido desfigurada por acréscimos ou modificações que não realizam uma nova síntese" (BRANDI, 2005). Portanto, na conservação não podemos ultrapassar o momento em que a obra entrou "no mundo da vida", e em decorrência disso adquiriu uma segunda historicidade em relação ao seu primeiro ingresso. É assim esclarecida por Brandi (2005) a premissa teórica para o tratamento das lacunas.

Interrogando deste modo, como objeto de nossa experiência atual, sem colocar em discussão a sua essência, mas tratando esta essência como objeto dessa forma de conhecimento, é que temos abordado as praças Getúlio Vargas, João Pinheiro e a praça Dom Epaminondas, em Serro.

Retomamos, então, o resultado de nossa percepção dos aspectos da "consistência da obra de arte na sua estrutura material" apresentada conforme preceitos de Camillo Sitte (1992), observando a obra de arte circunscrita como fenômeno, onde podemos, conforme Brandi (2005), tratar o problema das lacunas. 
Há de se ter respeito à integridade daquilo que chegou até nós, sem prejudicar o seu futuro, favorecendo a fruição do que resta e se apresenta da obra de arte "sem integrações analógicas, de modo que não possam surgir dúvidas sobre a autenticidade de uma parte qualquer da própria obra de arte" (BRANDI, 2005). Entretanto, cabe a verificação da permanência da obra de arte como "um inteiro" e não como "um total", possibilitando a reconstituição de sua unidade potencial. E, neste momento, Brandi (2005) admite a necessidade de se voltar para uma interrogação sobre a essência da obra de arte, rompendo os limites fenomenológicos estabelecidos para as análises de lacunas, com a intenção de realizar um juízo crítico, visando a reintegração delas como emanação da própria imagem e não como uma "integração analógica ou fantasiosa". É por isso que, para Brandi (2005), "qualquer eventual integração, mesmo se mínima, deverá ser identificável de modo fácil".

Por exemplo, o uso do tratteggio, (Figura 230), que se diferencia em técnica e matéria quando utilizado na reintegração, onde é possibilitada a manutenção dos limites fenomenológicos estabelecidos, uma vez que se trata de "fenômeno no fenômeno e como tal não se esconde, mas, antes - mais do que se submeter à experiência do outro - ostenta-se" (BRANDI, 2005).

Gaetani (2006) lembra que esta técnica foi criada por Brandi para a reintegração pictórica de lacunas, e que, a partir da interpretação das linhas marcadas pelas pinceladas em uma pintura, ele criou este procedimento de restauro com o desenho de linhas verticais e paralelas sobre a obra de arte danificada (Figura 230). O tratteggio possui atualmente várias releituras, tanto para a escultura 
como para a arquitetura, e devem ser realizadas a partir das interpretações de parâmetros formais e cromáticos, fundamentados em um dever crítico.

Na arquitetura, podemos destacar o exemplo da Torre Salomon de Visegrád, na Hungria, onde Giuseppe Zander realizou a reintegração da volumetria, não executando um falso, ou uma imitação. Ele utiliza uma releitura do tratteggio, representado na arquitetura como uma tradução contemporânea do elaborado método pictórico, em uma abstração da matéria, com reintegração em concreto, sugerindo a volumetria original - Figura 231 - (CARBONARA, 2002).

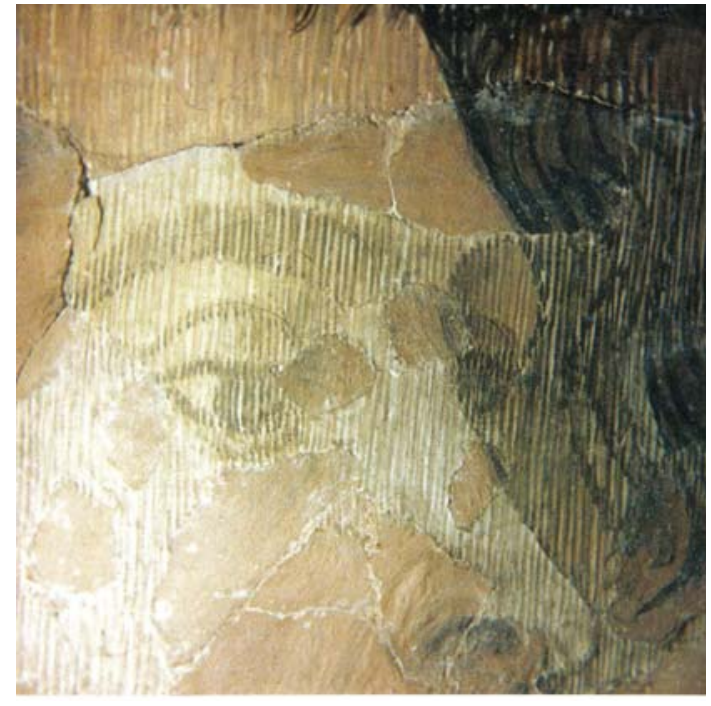

Figura 230. Viterbo, Santuário de Santa Maria della Verità, Capella Mazzatosta, afresco de Lorenço de Viterbo: Matrimonio della Vergine - tratamento da pintura com tratteggio.

Fonte: Andaloro (2006)

Figura 231. Visegrád (Ungria), Torre Salomon, restaurada em 1963-66 tratteggio em arquitetura.

Fonte: Carbonra (1997)

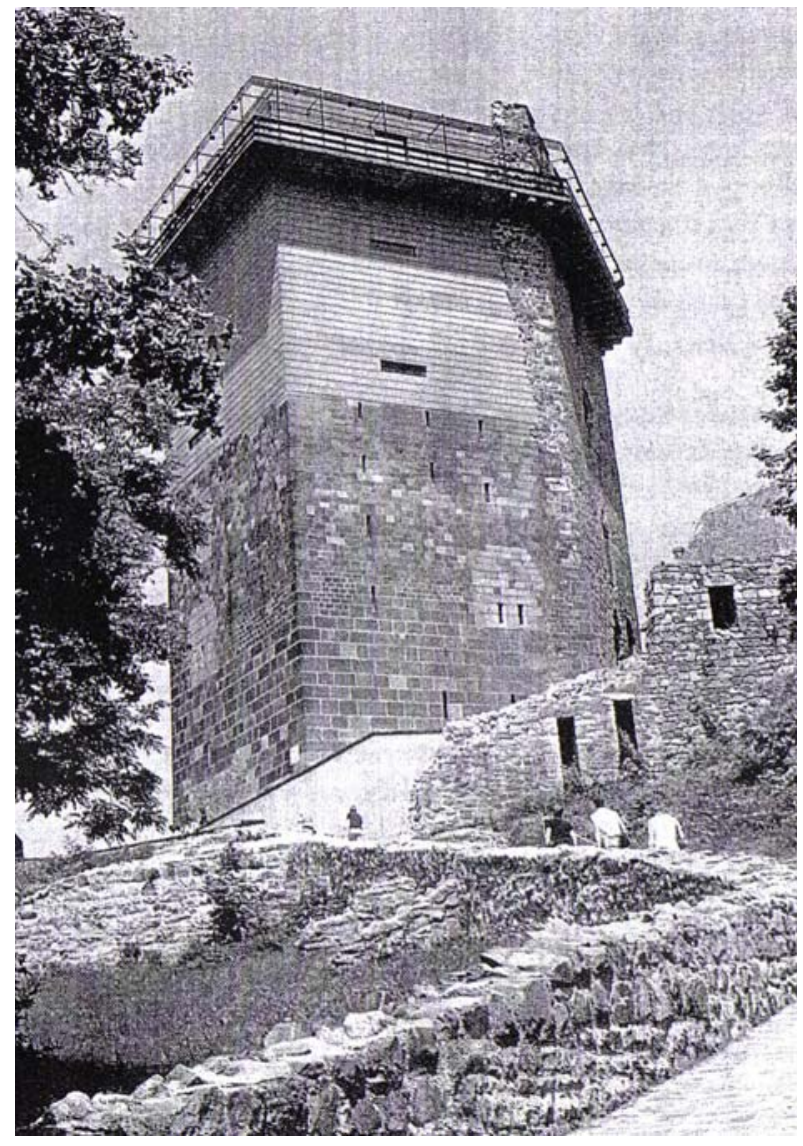


No caso do Serro, tendo como referência as áreas estudas que elegemos e reconhecemos em leitura crítica desenvolvida no capítulo 2, podemos entender que nelas "ocorre interrupção do tecido figurativo". Acreditamos que os danos de maior grandeza estejam atrelados às lacunas da praça Dom Epaminondas e da praça João Pinheiro.

Ao analisarmos a perda da Igreja de Nossa Senhora da Purificação - que tem sua lacuna denominada praça Dom Epaminondas - e, atrelado a isso, o conhecimento de que as integrações hipotéticas são contrárias aos princípios da Teoria da Restauração, nos voltamos a Cesare Brandi que, ao recorrer ao Gestaltismo, acredita que "o problema da lacuna se coloca em si e por si". O autor define, então, lacuna como

interrupção formal indevida e que poderemos considerar como dolorosa, [...], e sentiremos a lacuna como figura a que a imagem pictórica, escultórica ou arquitetônica serve de fundo, enquanto é ela própria e, em primeiríssimo lugar, figura (BRANDI, 2005, p.128).

Brandi (2005) apresenta, como solução para o problema da lacuna, a necessidade de diminuir o valor emergente com que ela se apresenta enquanto figura sobre a obra de arte, cuja solução é caso a caso, reduzindo-se esta emergência na percepção.

Ele ressalta que se deve remover qualquer ambigüidade da lacuna evitando que ela seja reabsorvida pela imagem da obra de arte, que poderia ser enfraquecida. Importa, portanto, que "a lacuna se encontre em um nível diverso daquele da superfície da imagem" (BRANDI, 2005), de maneira que seja fácil a distinguibilidade das integrações que conformam a unidade potencial da imagem e a 
efetiva diminuição da evidência da lacuna como figura. Brandi (2005) mostra com clareza que o tratamento da lacuna está diretamente ligado à percepção (Figura 235).
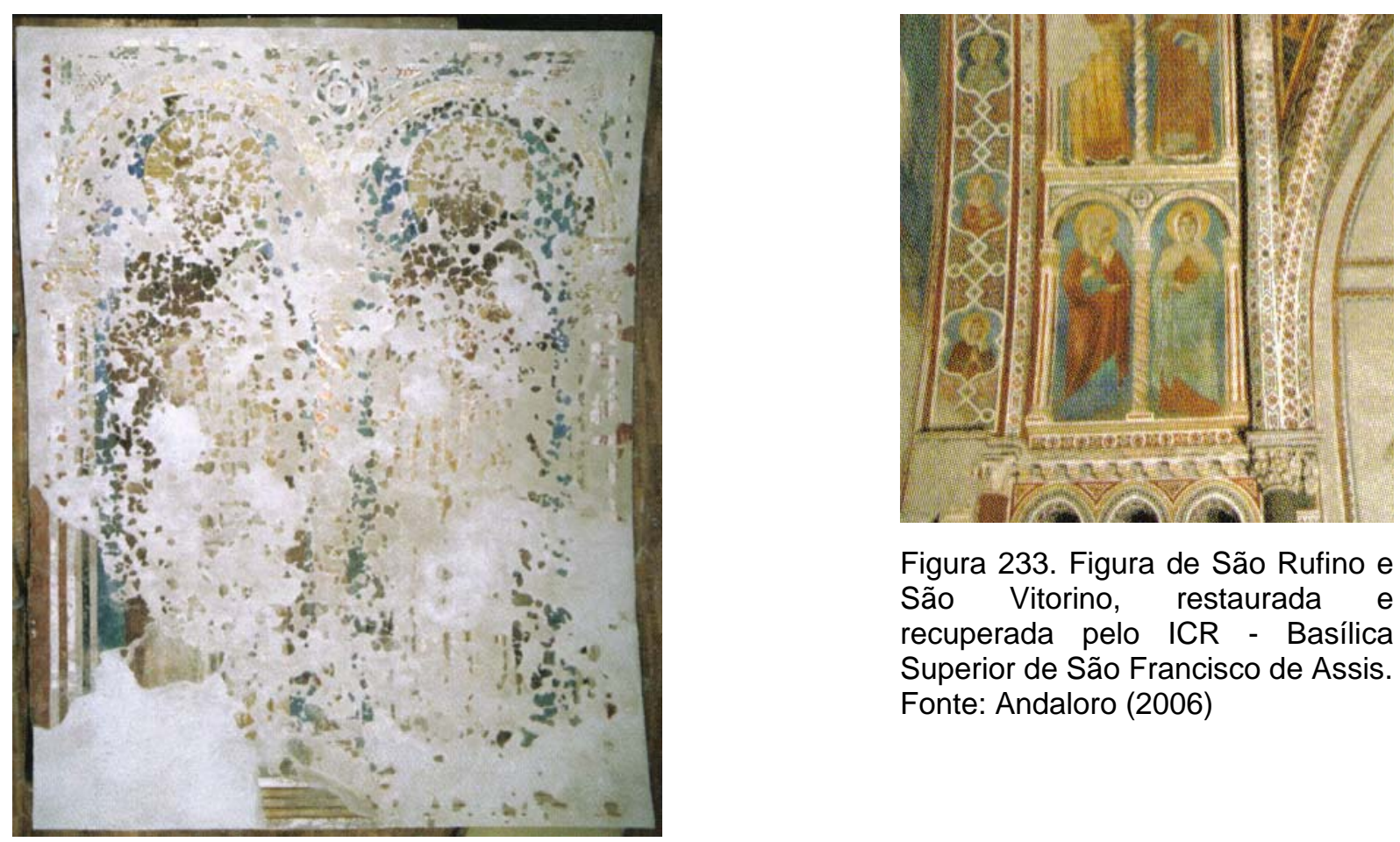

Figura 233. Figura de São Rufino e São Vitorino, restaurada e recuperada pelo ICR - Basílica Superior de São Francisco de Assis. Fonte: Andaloro (2006)

Figura 232. Figura de São Rufino e São Vitorino, recomposição dos fragmentos - Basílica Superior de São Francisco de Assis (IT)

Fonte: Andaloro (2006)

A reintegração da imagem deve ser feita a partir da unidade potencial da obra de arte, sem execução de intervenção fantasiosa. O tratamento da lacuna se realizará de maneira que não prejudique o futuro da obra nem altere sua essência (Figura 234, Figura 235). 


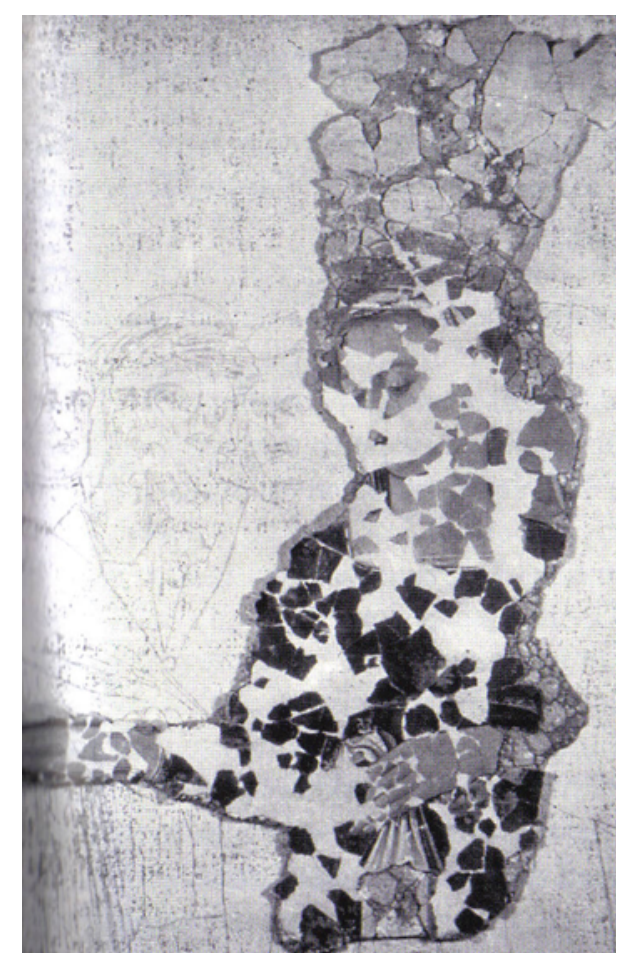

Figura 234. Viterbo, Santuário de Santa Maria della Verità, Capella Mazzatosta, afresco de Lorenço de Viterbo: depois da recomposição dos fragmentos e da estrutura do afresco.

Fonte: Andaloro (2006)

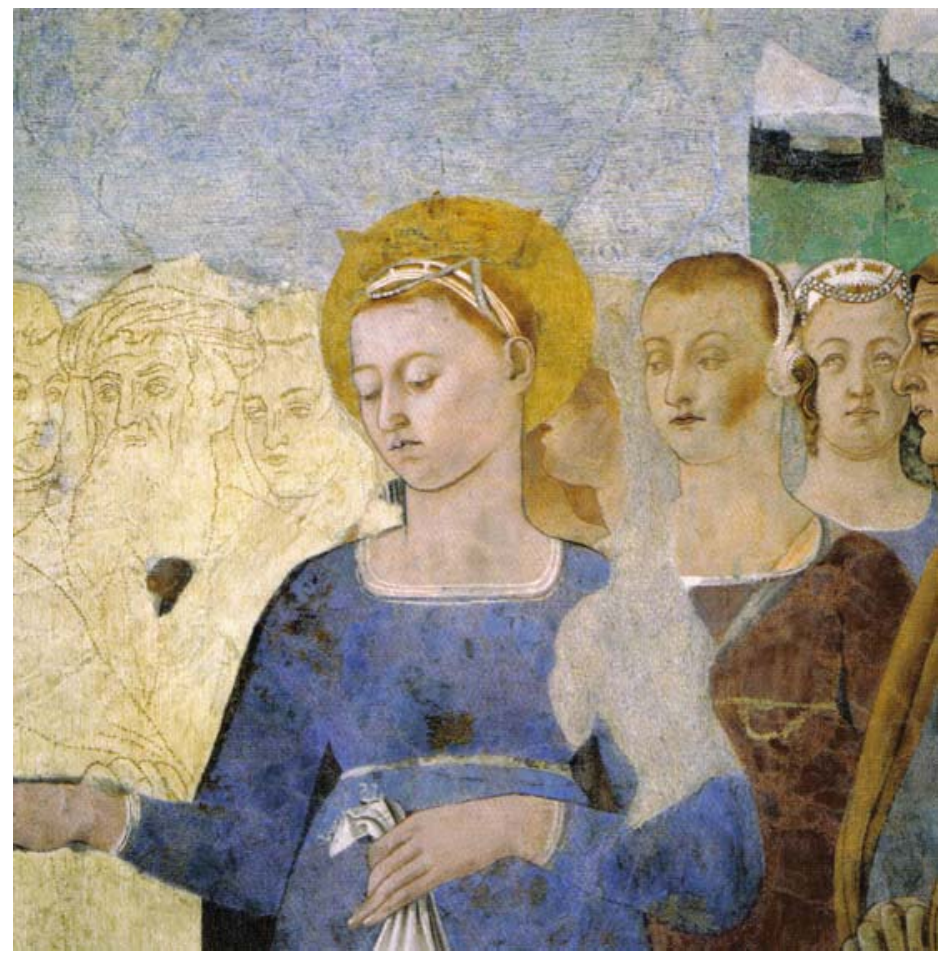

Figura 235. Viterbo, Santuário de Santa Maria della Verità, Capella Mazzatosta, afresco de Lorenço de Viterbo: a Virgem, depois da reintegração - restauro utilizando o tratteggio.

Fonte: Andaloro (2006)

No caso das lacunas no ambiente urbano de Serro, verificamos a necessidade da realização de uma restauração. Podemos ilustrar isso principalmente a partir dos casos da praça João Pinheiro e praça Dom Epaminondas. Já no caso da praça Getúlio Vargas, ao retomarmos as leituras realizadas no capítulo 2 "Estado da forma urbana", e nos colocarmos diante da praça - como "um inteiro" diante do condicionante brandiano na qual Kühl (2006) nos esclareceu como sendo "relacionado com a suspensão prévia de qualquer juízo sobre o domínio do conhecimento em consideração", a interpretação é outra. 
Percebemos que as transformações tal como a edificação construída em parte da praça Getulio Vargas está incorporada, pois removê-la seria apagar parte da história. E, lembramos que a prevalência de uma instância sobre outra, na dúplice polaridade apresentada por Brandi (2005) na definição de restauração, não deve acontecer. Se isso for necessário, em último instância, a estética, em especial, deve ser mantida - acreditamos não se tratar do caso da praça Getúlio Vargas -; a perda do passadiço do colégio Nossa Senhora da Conceição apesar de representar prejuízo à espacialidade do ambiente urbano em sua unidade, não compromete gravemente a elaboração artística da praça, que tem a seu favor a geografia - vales e colinas a sua volta, que contribuem positivamente na consolidação das transformações de sua espacialidade.

Ao nos colocarmos diante da obra de arte dessa maneira, acreditamos que a perda do passadiço esteja incorporada à paisagem urbana (pois edificações foram construídas no local das antigas, mas sem o passadiço). Entretanto, isso não significa a eliminação de uma discussão quanto à reintegração desta lacuna, apenas por que nossas leituras nos indicam a sua incorporação à condição atual do espaço urbano da cidade, dispensando esta possível reintegração. Entretanto, esta não é a realidade das outras praças.

A praça Dom Epaminondas se destaca por lacunas de supressão (eliminação de exemplares arquitetônicos - igreja e casas térreas); a João Pinheiro, por lacunas decorrentes de adição de novos elementos ao ambiente pré-existente. Podemos, então, indicar como demandas para restauração na praça Dom Epaminondas a integração espacial do ambiente urbano lacunoso pela ausência da Igreja da 
purificação (da Figura 236 à Figura 238) onde se exige que jamais seja refeito o próprio monumento, mas a reintegração da cidade enquanto obra de arte.

De acordo com Brandi (2005), no que se refere ao preenchimento dos vazios resultantes da ausência de "casas, casinhas acomodadas" - caracterização que podemos atribuir às duas casas térreas demolidas na rua Nagib Bahamed, (Figura 236), que configuram o mesmo ambiente da antiga igreja da Purificação (do outro lado da rua) - é permitido a recomposição do ambiente com "réplicas" das edificações, entendendo que haja ausência de caráter artístico da própria construção por si mesma, estando sua importância atrelada ao reconhecimento do conjunto urbano como a obra de arte em questão.
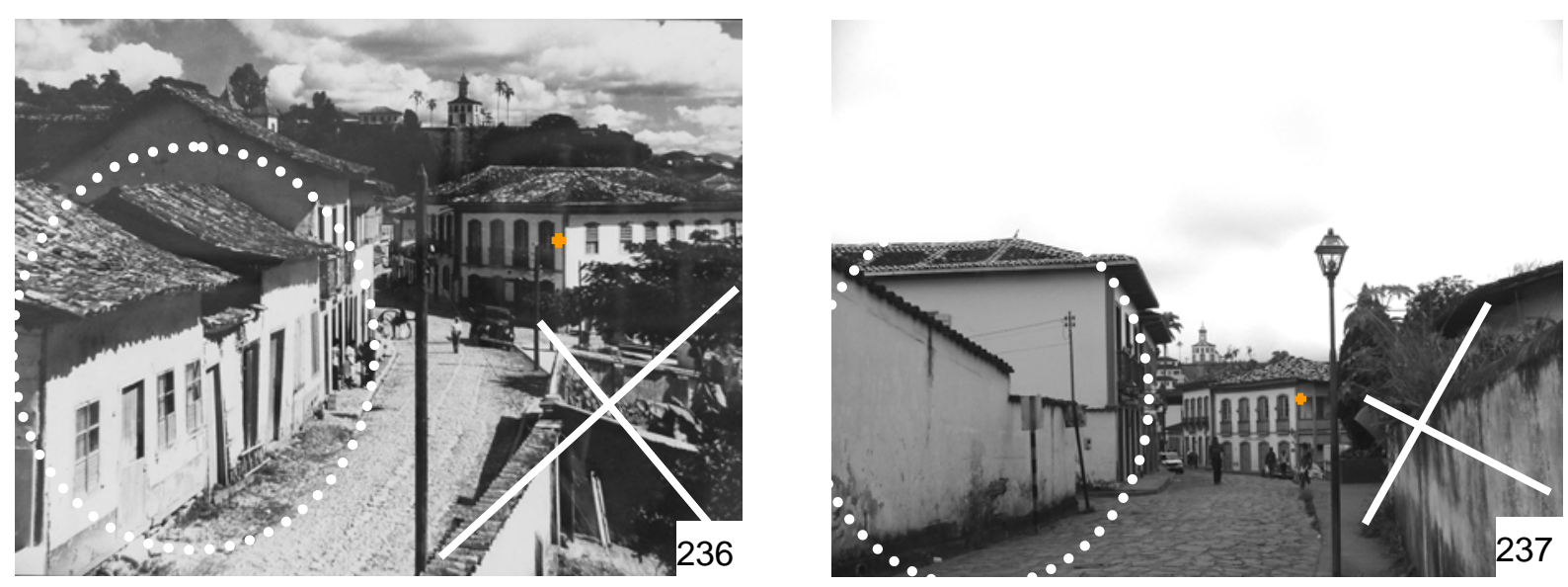

Figura 236. Serro, rua Nagib Bahamed com destaque para edificações térreas e lacuna da igreja da Purificação.

Fonte: IPHAN (2006)

Figura 237. Serro, rua Nagib Bahamed, com destaque para as lacunas das antigas casas térreas da figura 236, e lacuna da igreja da Purificação. 
Figura 238. Mapa com destaque para as lacunas indicadas nas figura 236 e Figura 237.

Fonte: adaptado de MC Arquitetos (2004)

No intuito de ilustrar uma intervenção de natureza urbanística que trata uma lacuna similar à da igreja da Purificação (diferente da "casa casinha acomodada" brandiana), identificamos a intervenção em "San Michele in Borgo a Pisa", projeto de Massimo Carmassi, como um exemplo adequado, por trabalhar a reintegração do tecido figurativo da unidade espacial do ambiente urbano - não estamos analisando a intervenção arquitetônica, mas a urbanística - (Figura 239 e Figura 240). Acreditamos que, neste caso, sem execução de réplicas ou imitações, recompõe-se a unidade potencial do conjunto urbano, resgatando a integridade perspéctica da rua, ou seja, procurou-se "reconduzir os dados espaciais do sítio ao estado o mais próximo possível daqueles originais" (BRANDI, 2005). 

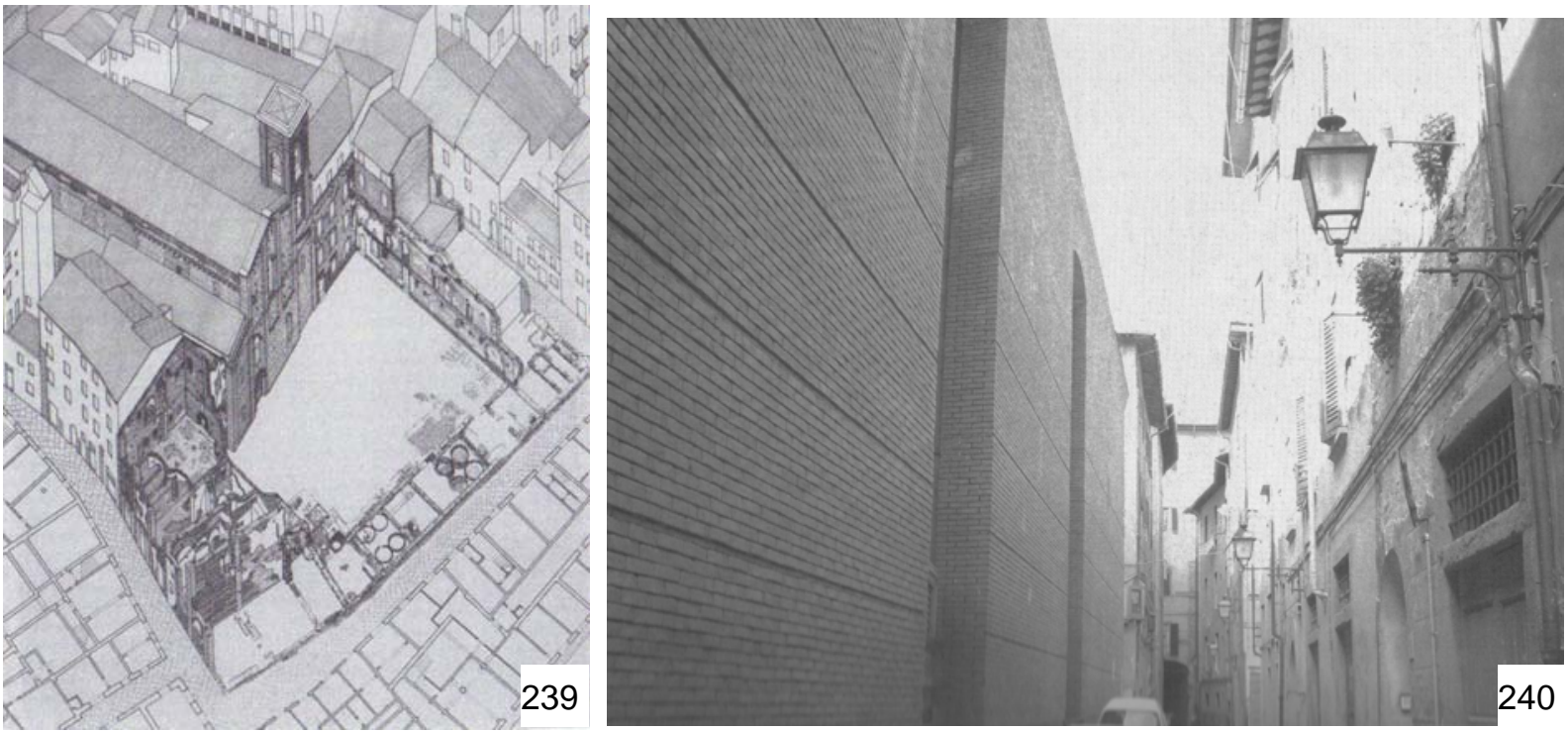

Figura 239. Pisa, área circunscrita a leste da Igreja de São Miguel, dentro do povoado do século XIII: situação antes da intervenção.

Figura 240. Pisa, sistematização urbana da área de São Miguel.

Fonte: Ranellucci (2003)

Diferentemente disso, no caso da praça João Pinheiro, em Serro, a lacuna se faz por adição e, por isso, entendemos que a ação restaurativa se torna mais complexa e difícil do que no caso da praça Dom Epaminondas - lacuna da Igreja da Purificação -, uma vez que na João Pinheiro o juízo de valor se torna evidente. Daí ser necessário que nos "retiremos" daquela leitura realizada sob o recorte fenomenológico efetuado diante da obra (o que no caso da lacuna por supressão não foi necessário). Precisamos considerar o juízo sobre o domínio do conhecimento em questão (BRANDI, 2005).

Entendemos que ocorrem transformações na obra de arte que não foram incorporadas e que devem, portanto, ser removidas. Podemos indicar a necessidade da retomada da livre circulação pelo beco do Carmo (Figura 242:c), assim como da eliminação dos degraus que criam o desnível entre a praça e a rua em frente a travessa Magalhães (Figura 241:a), e dos degraus de concreto entre a praça e a 
escadaria da igreja de Nossa Senhora do Carmo (Figura 243:b); e ainda a eliminação da própria marcação da rua (Figura 241), por entendermos que compromete expressivamente a percepção da praça em sua unidade como conjunto. Estes pequenos pontos de transformação da praça carregam aspectos geradores de graves alterações e deformidades na percepção imediata do ambiente e na sua relação com aquele circundante. Esses danos são correlatos tanto à estrutura formal da praça quanto aos monumentos que nela se conectam configurando o aspecto e estrutura do ambiente urbano em questão.

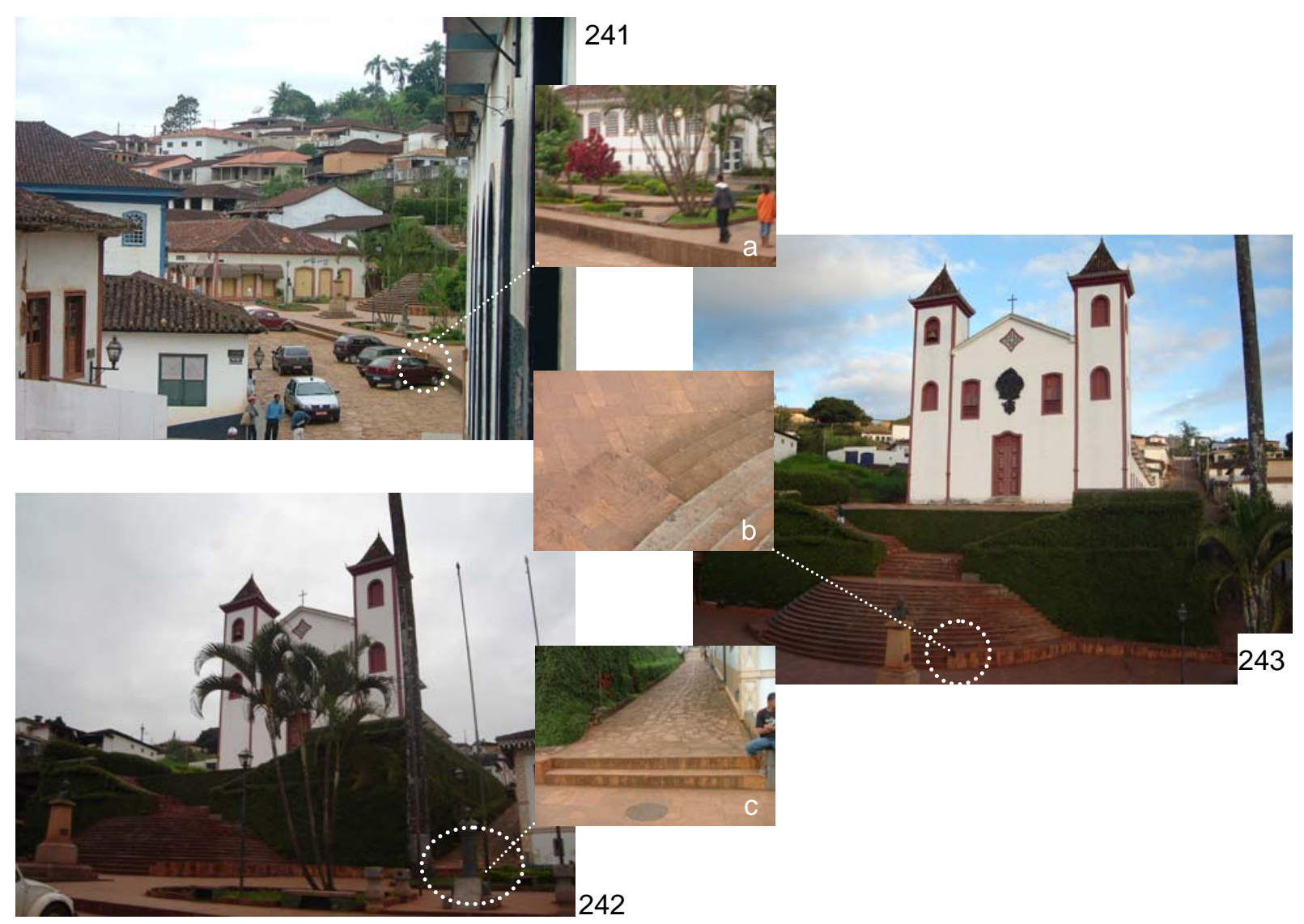

Figura 241. Serro (MG), praça João Pinheiro: a - demarcação de rua e desníveis.

Figura 242. Serro (MG), praça João Pinheiro: b - interrupção do Beco do Carmo.

Figura 243. Serro (MG), praça João Pinheiro: c - ampliação dos degraus de acesso à Igreja de Nossa Senhora do Carmo. 
Entretanto, as transformações em elementos da paisagem também interferem negativamente na figuratividade deste ambiente. Consideramos que a vegetação, nestes casos, por comprometer a legibilidade dos monumentos representa aspecto negativo conforme indica Camillo Sitte (1992). Acreditamos, porém, que ela já esteja incorporada aos dados espaciais do conjunto urbano, exemplificado neste caso pela praça João Pinheiro. Dessas transformações da paisagem, consideramos ainda que o parcelamento do solo e o conseqüente adensamento de novas construções no emolduramento da praça, antes caracterizado por massa arbustiva, representem danos inadmissíveis à adequada preservação do ambiente urbano. Neste caso, conforme Brandi (2005), o dano pede a remoção (se mostrando inviável), indicandonos que talvez, de maneira mais séria que nas demais obras de arte, o restauro preventivo seja o que melhor se aplique à cidade.

Apesar dos sérios danos presentes na praça João Pinheiro, entendemos que sua unidade potencial se mantém, devido à forte coesão que o espaço apresenta "o casario denso, nas laterais, fecha visualmente esse espaço, junto com a igreja, como que tentando estabelecer uma sobriedade impossível de ser imaginada nas vilas de Minas" (BITTENCOURT, 1999). 


\subsection{Se necessário,... restaurar}

O tema da preservação está fundamentado em, pelo menos, dois séculos acumulados de experiências e de reflexões, e as tendências atuais que possuem efetivamente caráter cultural e procuram seguir os preceitos estão sob sólido embasamento. Entre elas, tendo em vista o escopo desta pesquisa temos o dever de enfatizar por estar alicerçada na Teoria brandiana, denominada por Giovanni Carbonara "crítico-conservativa e criativa" e por Miarelli Mariani como "posição central" (KÜHL, 2006), aquela à qual eles são vinculados e se fundamenta na releitura de aspectos do chamado restauro crítico, e é incorporada principalmente pela Faculdade de Arquitetura de Roma, Firenze, Pescara e Napoli (CARBONARA, 2006).

Nessa vertente, a restauração acontece a partir de uma atitude conservativa, de maneira cautelosa, sem assumir nenhuma postura de congelamento nem renúncia à demanda de restauro, mas ao contrário, se necessário, a partir da criatividade "utilizada, porém, com respeito pela obra e não em detrimento dela" (KÜHL, 2006). Trata de importantes questões que são envolvidas na restauração, tais como a remoção de adições e reintegração de lacunas por supressão. A tendência "crítico-conservativa" é dialética entre as instâncias estéticas e históricas de cada obra, caso a caso, que exclui, na prática, qualquer tipo de interpretação mecânica de relação causa-efeito. É postura, pois, que devota grande atenção aos 
valores documentais e formais da obra como imagem figurada (KÜHL, 2006, p.11).

Importa, ainda, lembrarmos que o conceito de "bem cultural", atualmente, passa por entendimentos atrelados a uma dimensão quantitativa, com necessária tutela difusa, e adequado empenho e defesa da documentação históricotestemunhal considerada enquanto tal "testemunho dos valores de uma civilização, expressão de uma cultura material, e, como disse Argan (1998), 'objetos de pesquisa científica' " (CARBONARA, 2005, tradução da autora). Entretanto, a grande maioria dos bens a serem salvaguardados está, ainda, vinculada a categoria de obra e arte.

Acreditamos que devam ser ampliados estudos vinculados ao tema da restauração urbana, principalmente no Brasil, principalmente porque segundo Carbonara (2006, p.228, tradução da autora) "no difícil campo do restauro urbano, o único estudioso que hoje se pronuncia expressamente acerca da concepção crítica brandiana [...] é Francesco Blandino".

Carbonara (2006) afirma que a Teoria brandiana, com o "restauro crítico" seja efetivamente a linha mais correta e adequada à tutela do patrimônio cultural, e entendemos que neste grupo a cidade seja representante de destaque. Se apenas Francesco Blandino assumi esta atitude "crítico-brandiana" diante da restauração urbana, temos a convicção da fertilidade deste campo diante do estado de preservação de cidades como Serro.

Isso reforça a viabilidade de um restauro urbano com tais preceitos conceituais, nos trazendo, ainda, a esperança de uma adequada participação da 
restauração, quando necessária, para um futuro melhor de nossas cidades, uma vez que a realidade brasileira diante de um restauro responsável é pobre em contribuições, e destas, nenhuma voltada a restauração urbana.

O Brasil nos apresenta uma sólida carência quanto a publicações, divulgação das posturas conceituais adotadas diante de uma obra quando de sua restauração. Apresentam-se-nos muitos programas públicos para construções de novas sedes políticas administrativas, relacionados a lançamentos de grandes obras de arquitetura, entretanto quando nos voltamos para a preservação, conservação, parece que o entendimento é outro. Retomamos o exemplo do sobrado incendiado em 2003 na praça Tiradentes em Ouro Preto, cidade amplamente reconhecida por sua natureza artística, em que, para se intervir, cabem amplos debates e análises, crítica, histórica, estética, formal, visando um adequado tratamento para a sua preservação. Apesar da catástrofe, a obra de intervenção não nos trouxe debates conceituais, nem foi criado concurso que ampliaria a discussão ou apresentação dos critérios adotados. Ao contrário, talvez o que esse caso tenha trazido seja a ampliação de uma lacuna provocada pelo incêndio, a construção de um falso histórico e estético diante da cidade.

É sabido que em cada época, tanto no passado, como no presente e com certeza no futuro, a preservação acontece a partir de uma pertinência relativa. De acordo com conceitos já firmados pelos princípios brandianos - que constam na carta de Veneza - acreditamos que os critérios se transformam, e a conservação deve ser continuamente debatida dentro dos conceitos de cada época. Isto nos coloca diante da obra de arte, considerando o alargamento do conceito de bens 
culturais, com a responsabilidade de sua preservação para o futuro, na plenitude de sua autenticidade, sem comprometer o legado de outras épocas (a restauração em sua dúplice polaridade estética e histórica).

Torna-se relevante enfatizar positivamente a contribuição de Cesare Brandi no que se refere ao fato deque a partir do reconhecimento da obra de arte, enquanto obra de arte, ocorre automaticamente a imposição a quem a reconhece como tal, atribuindo-Ihe autoridade moral para sua conservação. Temos como desdobramento disto a responsabilidade de que qualquer intervenção nesta obra seja absolutamente fundamentada, uma vez que os resultados se perpetuarão através da obra às gerações futuras.

Entretanto, essa não é a realidade brasileira mais freqüente. Obviamente não se pode generalizar, mas há de se ter um entendimento global onde constantemente é exposta a grave deficiência de formação profissional de capacidade crítica atualmente, não só decorrente do domínio tecnológico que tem reduzido os debates conceituais e críticos diante de uma obra de restauração, conforme nos indica Baptista (2002), mas também, como é discutido por Barbosa (2005), tendo em vista a postura de arquitetos e engenheiros diante de uma cidade reconhecida como obra de arte, como bem cultural. Eles não a vêem nesta ordem, e se eximem da responsabilidade moral de sua salvaguarda. Portanto, a conservação acontece de maneira deficiente.

Pesquisadores e estudiosos brasileiros têm disponibilizado importantes publicações quanto ao debate político-administrativo da preservação cultural no 
Brasil, mas não, na mesma grandeza, à produção científica relativa a critérios conceituais, princípios teóricos que a priori deveriam reger a restauração, mostrando-se em um debate muito limitado, conforme nos esclarece Kühl (2006).

Atrelado a essa deficiência, enfatizamos que danos estão acontecendo ao patrimônio cultural, muitas vezes, decorrentes de um entendimento desvirtuado da real motivação da preservação do bem cultural, que, pelo constante alargamento de seu conceito, trouxe problemas quantitativo e qualitativo, colocando uma série de novas questões, tanto teóricas, quanto técnicas, práticas e éticas, que devem ser analisadas para serem enfrentadas (CARBONARA, 2006). Estas questões se mostraram evidentemente presentes em Serro, nos indicando se tratar de um problema global e não pontual. Tais tipos de distorções se mostram instáveis onde pressões políticas, econômicas têm se tornado hegemônicas. Entendemos que as formas de perceber os monumentos, o patrimônio cultural, são distintas, mas devem ser coexistentes.

É necessário ter em mente, porém, que o movente, aquilo que de início motivou a preservação não foi seu valor monetário, nem seu possível aproveitamento para um uso qualquer. A preservação foi motivada pelo fato de nesses bens ser reconhecido um significado cultural - seu valor estético (ou, mesmo não sendo "obras de arte", obras que possuem uma configuração) histórico, memorial e simbólico - tornando-os dignos de medidas para serm tutelados para as próximas gerações (KÜHL, 2006, p.16).

Acreditamos que são razões desta grandeza que devem guiar as ações, decisões de preservação, e que, no caso de conflitos, se busque, com responsabilidade conceitual, a solução adequada. E não, como temos observado acontecer, por exemplo, nos espaços públicos de Serro com relação às propostas 
de intervenção urbana do Programa Monumenta, em que percebemos falta de atenção e relativa deficiência quanto ao entendimento e reconhecimento da dimensão espacial da cidade em sua condição de patrimônio Cultural. Não há clareza conceitual; o que se observa são propostas de embelezamento, tratamento de fachadas, criação de cenários, visando retorno financeiro, com a ilusão de uma indústria do turismo (sem um coerente planejamento), e não um sólido e adequado posicionamento diante da obra, respeitando sua autenticidade, com vista à sua transmissão para o futuro, (como podemos observar a partir dos preceitos brandianos).

Destacamos que diante da cidade, nos relacionamos com instrumentos de suportes materiais que representam a memória da coletividade, e ao longo do tempo nos oferecem continuamente leituras novas e diferentes, que podem contribuir em futuras adaptações à realidade urbana daquele determinado contexto. Precisamos ter a consciência de que é através da conservação, se necessário utilizando a restauração, que nós garantiremos o direito de acessar o conhecimento que estes bens culturais trazem consigo. "Monumentos históricos - é necessário repetir à exaustão - são únicos e não reproduzíveis e devem portar consigo para o futuro seus elementos caracterizadores e as marcas de sua translação no tempo; todo cuidado é pouco" (KÜHL, 2006). 


\section{Referências}

ALBANO, C.; BORGES, C. (1994). Entre os limites do passado e as demandas do futuro: análise da cidade histórica de Ouro Preto, Minas Gerais. Cadernos de Arquitetura e Urbanismo, Belo Horizonte, v.2 , n.1, p.104.

ANDALORO, M. (org). La Teoria del Restauro nel Novecento da Riegl a Brandi: Atti Del Convegno Internzionale di Studi. Università Degli Studi Della Tuscia. Viterbo: Nardine Editore, 2006, 461p.

ANDRADE, C.R.M. (1993). Dar forma ao informe: o urbanismo e a crise da cidade moderna. In: GONÇALVEZ, M.F. O Novo Brasil urbano: impasses, dilemas, perspectivas. Porto Alegre: Mercado Aberto. p.337-358.

ANDRADE, A.L.D. (1993). Um Estado completo que pode jamais ter existido. 169f. Tese (Doutorado) - Faculdade de Arquitetura e Urbanismo, Universidade de São Paulo, São Paulo, 1993.

AMARAL, A. (1995). Stages in the formation of Brasil's cultural profile. The Journal of Decorative and Propaganda Arts, Miami, n.21, p.14.

ARGAN, G.C. (1995). A Arte e crítica de arte. 2.ed. Tradução de Helena Gubernatis. Lisboa: Estampa. (Coleção Teoria da Arte).

. (1998). História da arte como história da cidade. 4.ed. Tradução de Píer Luigi Cabra. São Paulo: Martins Fontes. (Coleção a).

ASSOCIAÇÃO BRASILEIRA DE NORMAS TÉCNICAS (2002a). NBR 10520: informação e documentação: citações em documentos: apresentação. Rio de Janeiro. 
Rio de Janeiro.

(2202b). NBR 6023: informação e documentação: referências: elaboração.

AZEVEDO, P.O. (2003). A Restauração arquitetônica entre o passado e o presente. RUA: revista de urbanismo e arquitetura, Salvador, v.1, n.8, p.18-23, jul./dez.

BAPTISTA, M.J. (2002). Carta de Cracóvia 2000: os princípios de restauro para uma nova Europa. Revista Patrimônio Estudos, Lisboa, n.3, p.93-99. Disponível em:<http://www.ippar.pt>. Acesso em:6 abr. 2006.

BRANDI, C. (2005). Teoria da restauração. Tradução de Beatriz Mugaya Kühl. Cotia: Ateliê.

BRASIL (1937). Ministério da Educação e Cultura. Decreto lei 25. Rio de Janeiro, DF.

BITTENCOURT, L.C. (1999). Regularidades do visível. 155 f. Tese (Doutorado) Faculdade de Arquitetura e Urbanismo, Universidade de São Paulo, São Paulo, 2000.

BRESCIANI, M.S. (2004). Camillo Sitte entre a estética romântica e a eficiência moderna. In: CONGRESSO INTERNACIONAL DE HISTÓRIA URBANA, 2004, Agudos. Camillo Sitte e a circulação das idéias de estética urbana. Europa e América Latina: 1880-1930. Agudos/SP: Cultura Acadêmica. 1CD-ROM.

CAMPELLO, G. (1999). A Serviço do patrimônio 1994/1998. Rio de Janeiro: Brasileira.

CANNIGIA, G.; MAFFEI, G.L. (2001). Interpretation basic building: architectural composition an building typology. Firenze: Alínea.

CARBONARA, G. (2005). Apresentação. In: BRANDI, C. Teoria da restauração. 2.ed. Tradução de Beatriz Mugaya Kühl. Cotia: Ateliê.

CARBONARA, G. (2002). Avvicinamento al Restauro: Teoria, storia, monumenti. Milano: Liguori Editore. 723p. 
CARBONARA, G. (2000). Le tendenze attuali del restauro in architettura. In Enciclopedia Universale dell'Arte, Secondo supplemento, Nuove conoscenze e prospettive del mondo dell'arte. Novara: Istituto Geografico de Agostini. pp. 533-541.

CARBONARA, G. (2006). Brandi e il restauro archittonico oggi. in ANDALORO, Maria (org). La Teoria del Restauro nel Novecento da Riegl a Brandi: Atti del Convegno Internzionale di Studi. Università Degli Studi Della Tuscia. Viterbo: Nardine Editore. p. 225-238.

CASTRIOTA, L.B. (Org.). (2003). Urbanização brasileira: redescobertas. Belo Horizonte: C/Arte.

CASTRO, S.R. (1991). O Estado na preservação de bens culturais: o tombamento. Rio de Janeiro: Renovar.

CHAGAS, P. P. (1978). Teófilo Ottoni, Ministro do Povo. Belo Horizonte: Itatiaia. Brasília: INL.

CHARRE, A. (1990). La riorganizzazione estetica e topogefica della città di Lione. In: ZUCCONI, G. Camillo Sitte e i sui interpreti. Milano: Urbanística Francoangeli. p.221-228.

CHOAY, F. (2001). A Alegoria do patrimônio. Tradução de Luciano Vieira Machado. São Paulo: Estação Liberdade; UNESP. . (1980). A Regra e o modelo. São Paulo: Perspectiva.

COBRA, R.Q. (2005). Filosofia contemporânea. Disponível em:<www.cobra.pages.nom.br>. Acesso em: 20 nov. 2005.

COSTA, L.A.M. (2004). De Immanuel Kant a Camillo Sitte as noções de história, estética e projeto em: a construção das cidades segundo seus princípios artísticos. In: CONGRESSO INTERNACIONAL DE HISTÓRIA URBANA, 2004, Agudos. Camillo Sitte e a circulação das idéias de estética urbana. Europa e América Latina: 1880-1930. Agudos/SP: Cultura Acadêmica. 1CD-ROM.

CROCE, B. (1990). Breviário de estética aesthetica in nuce. Tradução de Rodolfo llari Jr. São Paulo: Ática.

CUNHA, C. dos R. (2006). Alois Riegl e "O Culto Moderno dos Monumentos". Revista CPC. São Paulo, v.1, n.2, p.6-12, maio/out. 2006. Disponível em <http://www.usp.br/cpc/v1/php/wf07_revista_capa.php?id_revista=2>. Acesso em: 10 dez. 2006. 
DELSON, R.M. (1997). Novas vilas para o Brasil colônia: planejamento espacial e social no século XVIII. Tradução de Fernando de Vasconcelos Pinto. Brasília: Alva.

DOURADO, O. (2003). Por um restauro urbano: novas edificações que restauram cidades monumentais. RUA: revista de urbanismo e arquitetura, Salvador, v.1, n.8, p.8-13, jul.dez.

ESCOLA DE ARQUITETURA DA UFMG - EA UFMG - (2006). Imagens cedidas pelo Laboratório de Fotodocumentação Silvio De Vasconcellos (reproduções e de própria autoria).

ESCOLA DE ARQUITETURA DA UFMG - EA UFMG - (2006). Plano Diretor do Município de Serro. Coordenação Leonardo Barci Castriota. Parceria com Fundação João Pinheiro e Prefeitura Municipal de Serro.

FENOMENOLOGIA. In: HOUAISS, Antônio. Dicionário eletrônico Houaiss da língua portuguesa. Rio de Janeiro: Objetiva. 2001.

FEILDEN, B. M. (1982). The Principles of Conservation. in AA. VV., Conservation of Historic Stone Buildings and Monuments. Report of the Committee on Conservation of Historic Stone Buildings and Monuments. Washington D.C. 1982. Disponível em: http://w3.uniroma1.it/bertirestauro. Acesso em: 19 out. 2006.

FUNDAÇÃO JOÃO PINHEIRO (1994). Serro. In: Minas Gerais monumentos históricos e artísticos: circuito do Diamante. Revista Barroco, Belo Horizonte, n016, p. 139-226. Edição comemorativa. (Coleção Série Municípios e Regiões Mineiriana).

GAETANI, M. C. (2006). La reintegrazione delle lacune attraverso la técnica del tratteggio: considerazioni sul método. in: ANDALORO, Maria (org). La Teoria del Restauro nel Novecento da Riegl a Brandi: Atti Del Convegno Internzionale di Studi. Università Degli Studi Della Tuscia. Viterbo: Nardine Editore. p.277-284.

GIOVANNONI, G. (1925). Questioni di architettura nella storia e nella vita: edilizia, estética architettonica, restauri, ambiente dei monumenti. Roma : Societ'a d'Arte llustrata.

GONZÁLES-VARAS, I. (1999). Conservación de bienes culturales: teoria, historia, principios y normas. Madrid: Catedra. 
GUERRIERO, L. (2004). Corso teoria e storia del restauro. In: Seconda universita degli studi di Napoli. Disponível em:<http://www.unina2.it/menu/facol/Architettura >. Acesso em: 17 mar. 2006.

INSTITUTO DO PATRIMÔNIO HISTÓRICO E ARTÍSTICO NACIONAL. (1990). Serro do Frio: Vila do Príncipe. Belo Horizonte. (Relatório).

INSTITUTO DO PATRIMÔNIO HISTÓRICO E ARTÍSTICO NACIONAL. (2006). Documentação consultada localizada na $13^{a}$ Superintendência - Minas Gerais Centro de Documentação e Identificação - CDI. Belo Horizonte.

JOKILEHTO, J.I. (1986). A History of architectural conservation. 466p. PhD. Thesis - Instituto os Advanced Architectural Studies, The University of York, England. Disponível em:<http://www.iccrom.org>. Acesso em: 10 Sept. 2006.

JULIÃO, R.M. (1989). Churches in Ouro Preto and their spacial patterns. $52 \mathrm{f}$. M.Sc. Dissertation - Barltlett School of Architecture and Planning, London, 1989.

KOHLSDORF, M.E. (1996). A Apreensão da forma da cidade. Brasília: Unb.

KÜHL, B.M. (1998). Arquitetura do ferro e arquitetura ferroviária em São Paulo. São Paulo: Ateliê; FAPESP, Secretaria da Cultura.

KÜHL, B. M. (2006). História e Ética na Conservação e na Restauração de Monumentos Históricos. Revista CPC. São Paulo, v.1, n.1, p.16-40, nov. 2005/ abr. 2006. Disponível em <http://www.usp.br/cpc/v1/php/wf07_revista_capa.php?id_revista=2>. Acesso em: 3 set. 2006.

LAMERS, P. (Coord.). (2003). Teoria da arquitetura até aos nossos dias: 117 tratados apresentados em 89 estudos. Tradução de Maria do Rosário Paiva Baléo. Lisboa: Vernáculo.

MC ARQUITETOS (2004). Inventário Municipal de Serro. Prefeitura Municipal do Serro. Documentação de pleito junto ao IEPHA para Lei de Incentivo a Cultura do Estado de Minas Gerais.

MERLEAU-PONTY, M. (1999). Fenomenologia da Percepção. Tradução Carlos A. De Moura. São Paulo: Martins Fontes.

MOTTA, L.. (1987). A SPHAN em Ouro Preto: uma história de conceitos e critérios. Revista do Patrimônio Histórico e Artístico Nacional, Rio de Janeiro, n.22, p.108122. 
MORRIS, A.E.J. (1985). Historia de la forma urbana: desde sus orígenes hasta la revolución industrial. Barcelona: Imprenta Juvenil. (Colección Arquitectura/Perspectivas).

MOULDON, A.M.V. (1997). Urban morfology na emerging interdisciplinary field. Journal of the International Seminar on Urban Form, Dorchester, v.1, n. , p.3, May.

MOURÃO, F. A. A. (2001). O Coroamento do Milênio através de uma Metamorfose iniciada em Vila Rica - Paixão e Estética na Leitura do traçado das duas cartas urbanas. Urbanismo 3 de origem portuguesa: Revista do Centro de estudos de urbanismo e de arquitetura, Lisboa, n³, abril. Disponível em <http://urban.iscte.pt/Revista/numero3/artigos/artigo_04.html>. Acesso em: 5 nov. 2004.

MURATORI, S. (1959). Studi per uma operante storia urbana de Veneza. Roma: Instituto Poligrafhico dello Stado.

PEREIRA COSTA, S.A. (2004). Transformações, conflitos, perdas e permanências na paisagem sul-metropolitana de Belo Horizonte. $315 \mathrm{f}$. Tese (Doutorado) - Faculdade de Arquitetura e Urbanismo, Universidade de São Paulo, São Paulo, 2004

PROGRAMA MONUMENTA (2005). Conjunto Arquitetônico e Urbanístico da cidade de Serro/MG: Perfil do Projeto. Programa De Gerenciamento Intensivo do PPA 2004-2007. Objeto do Contrato de Empréstimo 1200/Oc-Br, Entre a República Federativa do Brasil e o Banco Interamericano de Desenvolvimento - Bid: Governo Federal, Governo do Estado de Minas Gerais, Prefeitura Municipal de Serro.

PESSOA, J.S.B. (1999). Lúcio Costa: documentos de trabalho. Rio de Janeiro: IPHAN.

POUGY, E. (2005). Cultura? Diponível em <http://www.cronopios.com.br/site/colunistas.asp?id=681>. Acesso em 01 nov. 2006.

RANELLUCCI, S. (2003). II Restauro urbano: teoria e prassi. Roma: UTET.

REIS FILHO, N.G. (2000). Contribuição ao estudo da evolução urbana do Brasil: 1500/1700. São Paulo: Pini. 
ROSSI, A. (2001). A Arquitectura da cidade. Tradução de José Charters Monteiro. Lisboa: Cosmos.

SAINT-HILAIRE, A. (1975). Viagem pelas Províncias do Rio de Janeiro e Minas Gerais. Tradução de Vivaldi Moreira. Minas Gerais: Itatiaia. (Coleção Reconquista do Brasil, 4).

SALGADO, I. (2004). Uma leitura sobre a concepção estética de Camillo Sitte: a construção do espaço perspéctico. In: CONGRESSO INTERNACIONAL DE HISTÓRIA URBANA, 2004, Agudos. Camillo Sitte e a circulação das idéias de estética urbana. Europa e América Latina: 1880-1930. Agudos/SPI: Cultura Acadêmica. 1CD-ROM.

SANTOS, J.F. (1978). Memórias do distrito diamantino. Petrópolis: Vozes; Brasília: INL.

SILVA, D.A. F. (1928). Memória sobre o Serro antigo. Serro: Serrana..

SITTE, C.; ANDRADE, C.R.M.A. (Org.). (1992). A Construção das cidades segundo seus princípios artísticos. Tradução de Ricardo Ferreira Henrique. São Paulo: Ática.

SMITH, R. (1969). A Arquitetura civil do Brasil colonial. Revista do IPHAN, Rio de Janeiro, n.17, p.28.

SCHORSKE, C.E. (1988). Viena fin-de-siècle: política e cultura. Tradução de Denise Bottmann. São Paulo: Companhia das Letras.

SCHWARTZMAN, S.; BOMENY, H.M.B.; COSTA, V.M.R. (2000). Tempos de Capanema. 2.ed. São Paulo: Paz e Terra; Fundação Getúlio Vargas. Disponível em:<www.schwartzman.org.br>. Acesso em: 9 dez. 2004.

SECRETARIA DO PATRIMÔNIO HISTÓRICO E ARTÍSTICO NACIONAL/ FUNDAÇÃO NACIONAL PRÓ-MEMÓRIA. Proteção e revitalização do patrimônio cultural no Brasil: uma trajetória. Brasília: SPHAN. 1980. 196P. (Publicações da Secretaria do Patrimônio Histórico e Artístico Nacional n³1).

TEIXEIRA, M.C.A. (2000). A Influência da cultura mulçumana nos traçados urbanos portugueses. Urbanismo 2 de origem portuguesa: revista do Centro de Estudos de Urbanismo e de Arquitetura, Lisboa, n.2, set. Disponível em:<http://urban.iscte.pt/Revista/numero2/default.htm>. Acesso em: 5 nov. 2004.

VASCONCELLOS, S. (1977). Vila Rica. São Paulo: Perspectiva. 
. (1980). A Formação urbana do Arraial do Tejuco. In: ARQUITETURA civil II. São Paulo: FAUUSP; MEC; IPHAN. p.99-115.

. (1983). Arquitetura dois estudos. Goiânia: MEC/SESU/PIMEG-

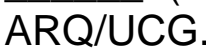

WHITEHAND, J.W.R. (1981). The Urban landscape: historial development and management; papers by M.R. Conzen. London: Acadeimc. (Special Publications Institute of British Geographers). 